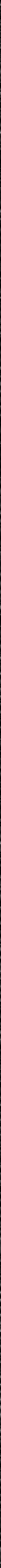




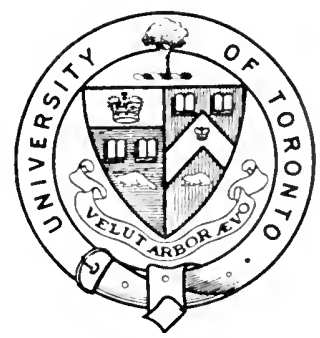

Jiresuted to

The Tithrary of the

Zlinuersity of Toranto

tug

Herbert Otto Frind, EsC. 

Digitized by the Internet Archive in 2007 with funding from

Microsoft Corporation 
MY CLIMBING ADVENTURES IN FOUR CONTINENTS 
BY THE SAME AUTHOR

SIBERIA. A Record of Travel, Climbing and Exploration. With 46 Illustrations and 2 Maps. Cheap Edition. Large Crown $8 v o$, cloth, 5 s.

"The story of his adventures and experiences makes good reading, all the more that it is told plainly-so many tales from the hills-though never without a graphic touch."-Daily Chronicle.

"A more exhaustive and more interesting account of Siberia has rarely seen the light."-The Graphic.

LONDON : T. FISHER UNWIN. 


$$
\text { - }
$$




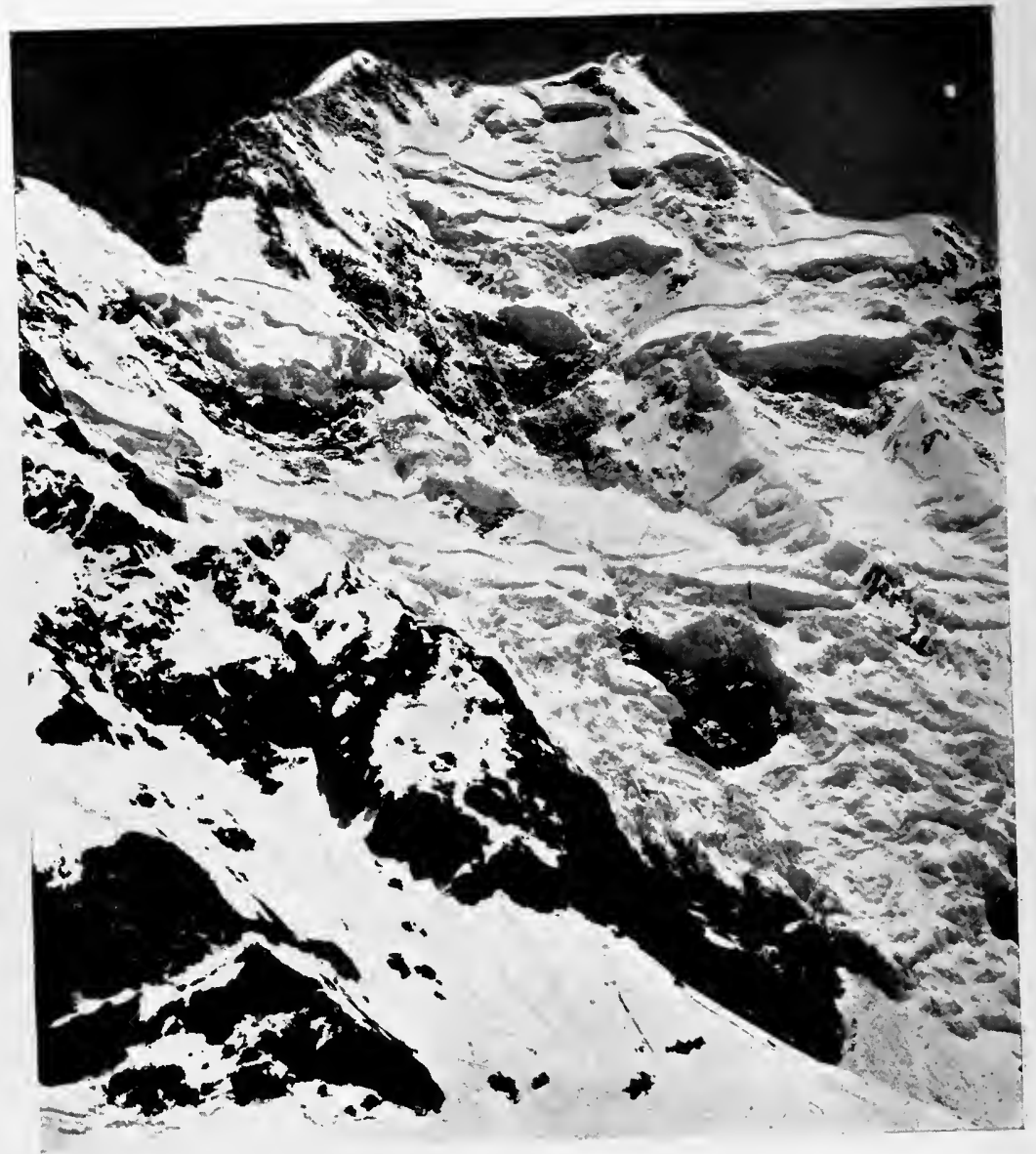

MOUNT COOK FROM TASMAN SIDE, UP WHICH THE AUTHOR'S PARTY CLIMBED. 


\title{
MY
}

\section{CLIMBING ADVENTURES \\ IN FOUR CONTINENTS}

\author{
BY \\ SAMUEL TURNER, F.R.G.S. \\ AUTHOR OF " SIEYRIA: A RECORD OF TRAVEL, CLIMEING AND EXPLORATION,"
}

\author{
With 74 Illustrations
}

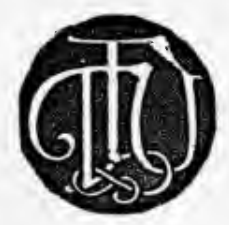

T. FISHER UNWIN

\section{LONDON}

Adelphi Terrace.
LEIPSIC

INSELSTRASSE 20

MCMXI 


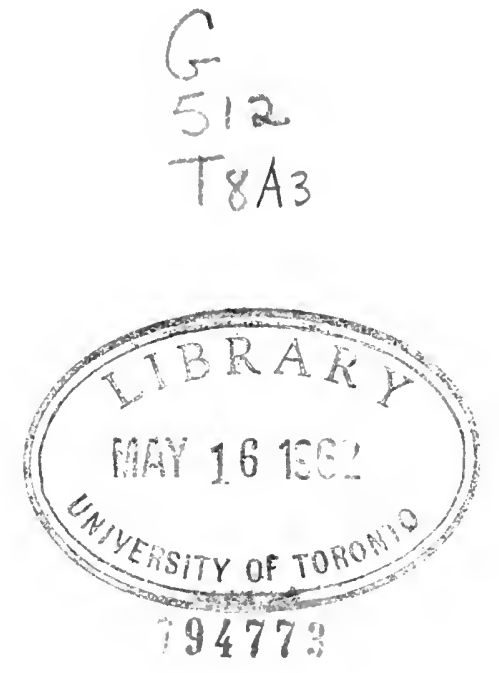

All Rights Reserved 


\section{CONTENTS}

\section{BOOK I}

CHAP.

I. Novice Stage of Climbing-I Catch Mountain

PAGE

Fever on Mount Pilatus, and afterwards

Climb Mont Blanc . . . .

II. Mountain Climbing in the Second Degree of Difficulty - Ascent OF MATterhoRN IN Record Time-I Chimb Monte Rosa with

a Novice, making it a dangerous climb .

III. Extraordinary Rock Climbs - Climbing

Walnut Tree "Matterhorn"-Ilam Rock

Climb, Dovedale, Derbyshire . .

IV. South to North Traverse of Aiguille des

Charmoz Pinnacle, the most dangerous rock Climb in SwItzerland-THe AtTempt ON Aiguille DU DRU-SNowstorm-Tour of Mont Blanc

\section{BOOK II}

V. Travel and Exploration in Siberian Mountains IN WinTER-MOUNTAIN-Climbing aND EXPLORATION •

VI. More Mountain Discovery - Climbing and EXPLORATION . . . . . $1 \times 7$

ViI. Climbing Belukha - A Narrow Escape of BEING CARRIED DOWN THE MOUNTAIN BY Avalanche . . . . . 


\section{Contents}

CHAP.

PAGE

ViII. I am Compelled to give up; am Poisoned, AND have Inflammation of the Eyes $\quad$ I 159

IX. Cumberland Climbing - Discussion of the Faculty that makes a Climber • • 167

\section{BOOK III}

X. First Winter Ascent of Mount Ngaruruhoe and First Climb of Priest's Cap .

XI. The Monarch of the New Zealand Alpsthe First and Only Traverse of Mount $\mathrm{COOK}$..$\quad$. $\quad . \quad$. 201

XII. A South American Climb-My Attempt to RUSH ACONCAGUA

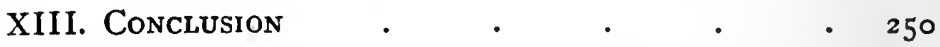

APPENDIX • $\quad \cdot \quad$. $\quad . \quad$. $\quad . \quad 265$

INDEX $\quad . \quad$. $\quad . \quad 279$ 


\section{IJIST OF ILLUSTRATIONS}

Mount Cook From TASMan Side, uP Which the Author's Party Climbed . . Frontispiece

Medal Presented to the Author by the Russian Imperial Geographical Society . To face $p$. I 5

Aiguille des Charmoz, and Mont Blanc in THE BACKGROUND . . . . . " 26

AUTHOR AND HIS GUIDE UNDER SHOULDER OF THE MATTERHORN . . . . .

UP The Shoulder OF the Matterhorn. DR Murett and the Guide in Storm (Photographed by Author)

Author Climbs Easy Slopes Garth Stone QUARRY

(Photo. during his first climb)

Author and Guide. Italian Side of Summit OF MATTERHORN • • • . • " 37

Summit of the Matterhorn . . . . . $\quad$. 37

Party in Storm, Top of Shoulder of MatterHORN (I 4,000 Feet above Sea Level, Clouds 3000 Feet below) . . . . . " 38

A. B. Holmes on the Summit of the Highest RIDGe of Monte Rosa (15,217 Feet above Sea Level)

The Dutchman, Author, and Guide (from Left to Right) on MONTE Rosa Slopes.

Ilam Rock, Dovedale, Derbyshire . . " " 60

Summit of Aiguille des Charmoz and Grépon, with Aiguille du GÉant in Distance?

Author's Party and Aiguille des Charmoz in the Distance

A. H. Binns poses for Author to РhotoGRAPH (5000 Feet above Mer-de-Glace, seen below). 
A. H. Binns falls into a Crevasse (Author photographed him before pulling him out)

"Is It Possible?"

(Author climbing round overhanging precipices on the Aiguille des Charmoz)

Porter Misses his Footing and Dangles over 5000 Feet of Precipice

Author Climbing Awkward Pinnacle with ROUND TOP, MAKING USE OF ONLY FOOTHOLE

A. H. Binns Climbing a Crack, Aiguille des Charmoz (Photo. by Author)

Author's Party Climbing Crack on Charmoz PRECIPICES

South Slopes of Belukha ( $\mathrm{r}_{4}, 800$ Feet)

Mount Bronyar, Opposite "Windy Camp"

Saptam Mountain, near Katunda .

We Cross the River Akkem in Canoe

Katunskië-belki, with Belukha West Peak

on Extreme LeFT, from a height of I I,000

Feet

KatUMSKIË-BelKi, With WilleR's PeAK (I 7,800

Feet, on extreme right)

Glacier Near Willer's Peak

END of Frozen Lake.

KatUNSKIË-bELKI AND Lateral MoRaine, fROM "Windy Camp"

Ice-Glaced Peaks, from Willer's Peak

Photograph of the Author taken by himself

ON THE TOP OF SOME STEEP ROCKS .

Snow-bound Tent and Unnamed Peak, at 4 A.M.

"Desolate Camp," Tent on Moraine and

Belukha West Peak

I 32

North Face of Belukha from Glacier, Twin

Peaks (I4,80o feet) .

Kalmuck Bark Hut, Akkem Valley . . " 159

Kalmucks on Akrem Pass . . . "

My Hunter, his Wife and Mansion . . " 


\section{List of Illustrations}

Author's Party on River Biysk Broken Ice To face $p .162$

THe ONLY SLEDGes We MET FOR 400 Miles . " 164

The Pleasures of a thaw . . . . " 164

Mount Ngaruruhoe, Extinct Volcano, New ZeaLAND

Liebig Range from tasman Glacier

" $\quad \mathbf{7 7}$

" 178

AUthor on Hard Frozen SLOPES of Mount

NgaruRuhoe PhotographS Himself BY LoNG

TUBE

Summit Snow Slopes of Priest's Cap Moun-

tain, New Zealand Alps . . . " 180

Base Camp for Priest's Cap Climb . . " 180

AUthor's Party ON THE March UP THE

TASMAN GLACIER a .

(Notice the heary loads on the backs. We did our own portering)

Summits of the Likbig Range from the

Summit of Priest's Cap . . .

io, O00 FeEt OF Mount CoOK From Summit of

Priest's Cap Looking across the Tasman

VALLEY

Author Lent a Jersey to the Roadman and

Photographed Him at THE Spot on

NGaruruhoe Where he Promised to wait

Malte Brun Hut

(Author's party dig it out of the unusually deep snow, Tasman glacier)

Author Exploring a Crevasse

Author Climbing out after Exploring A

Crevasse

Malcolm Ross on Summit of Mount Cook

(He tried to climb Mount Cook for twenty years, and was grateful that Author's expedition gave him success at last)

Peter Graham, Author, and T. C. Fyfe on Summit of Mount Cook

author Leads T. C. Fyfe and Party up Mount CoOK Buttress

Hochstetter ICE FaLl

Steep Slopes near Mount Cook Bivouac and

Liebig Range, with Mount Priest's Cap in the Distant Clouds

Mount Cook Bivouac and Author's Party . " 184 ") 184

188

178 80

192
203


Three Summits of Mount Cook, and Lake

Pukokas down in the Distance . . To face $p .212$

(Author's party photographed Mount Cook summit for the first time)

Two Summits of Mount Cook . . . " $2 I_{4}$

HoOKer Side of Mount COOK from the

Hermitage . . . . . " 224

(Author's expedition descended this side)

The Gully up which Author's Party Com-

MENCEd the Aconcagua Climb . . " 23 I

The Three Peaks of Aconcagua and the 3000 Feet Precipices

231

A Peon, and Author Mounted, Starting for Aconcagua from Puente Del Inca Hotel in THE ANDES

Mount Aconcagua from the Valley, and AUthoR's PARTY . . . .

Author on Aconcagua, and Mount Orcones IN BACKGROUND

Mount Orcones (21,000 Feet) from Valley ORCONES

Small Tent Pitched near Huge Boulder (r6,000 Feet). Base Camp and Author's Party with Mules . . .

Small Tent at i6,000 Feet Camp. Aconcagua after Fresh Snow. Mules Coming uP VALLEY

Mount Orcones (21,500 Feet) from Slopes of ACONCAGUA

Loading Mules i6,000 Feet Camp after Heavy SNOWSTORM, ACONCAGUa

One of the Author's Proofs of Equilibrium. In Botanical Gardens, Kandy, Ceylon . Mount Orcones, and Author on Slopes of Aconcagua (over 20,000 Feet) 


\section{FOREWORD}

THIs account of some of my most risky climbing and exploration feats was written under trying circumstances on board ship on my last year's journey to Australia and back. I am a commercial man, not a literary man, and I write a plain, uncoloured narrative, feeling that I leave myself at the mercy of all literary critics.

My outfits and assistance for my climbs have been of the scantiest, compared with the up-to-date experienced expeditions organised for climbing in our days. In this respect, I have had more hardships to put up with. At the same time, I don't believe in these large cumbersome expeditions and the luxury the present-day climbers get in the mountains. I believe in the hard, stern fight between the man and the object of his ambition, without relying upon a lot of porters, guides, large tents, etc. The man who wishes to sleep in tents every night on a climb of Mount Everest is not made of hard enough stuff to get on its summit. 


\section{xii}

\section{Foreword}

He must be hard enough to be able to sleep on the snow without tent if necessary.

The Westminster Gazette, in reviewing my book on Siberia, called me "the most adventurous living climber," and I hope none of my critics will call me anything worse. 


\section{BOOK I}

A 

? 


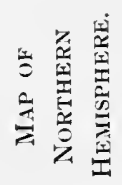
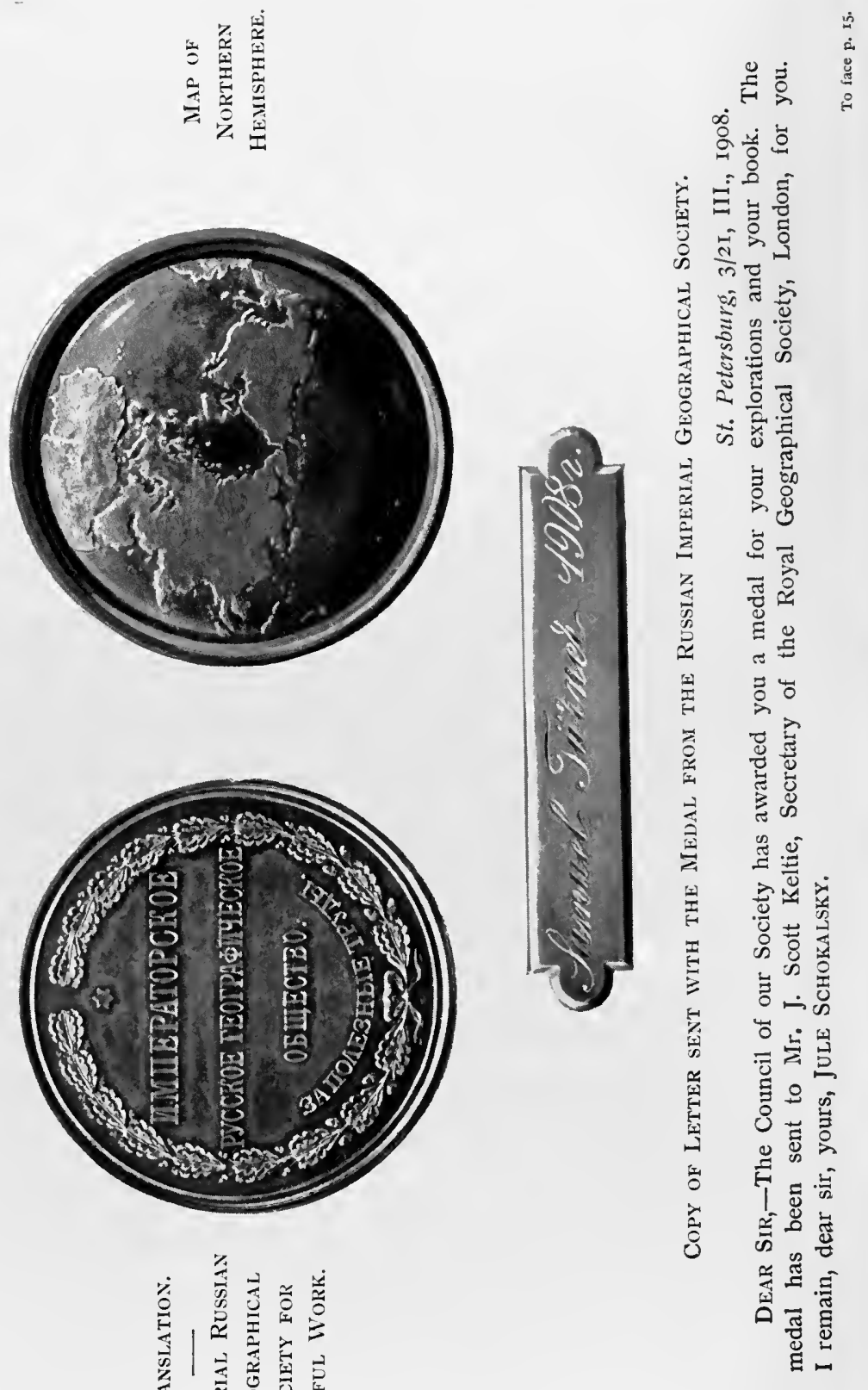

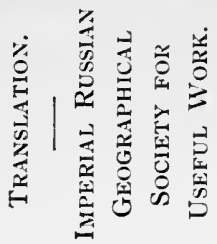




\section{CHAPTER I}

NOVICE STAGE OF CLIMBING - I CATCH MOUNTAIN FEVER ON MOUNT PILATUS, AND AFTERWARDS CLIMB MONT BLANC

$7 \mathrm{HE}$ inspiration to climb the highest European 1 mountains seized me as I gazed at them from the summits of Rigi and Pilatus fifteen years ago. It was my first sight of high, snow-capped mountains.

The summits looked unearthly high, mysterious when lit by the morning tint, and heavenly in the Alpine glow. These huge piles of the earth's crust fascinated me into feeling that any risks taken to conquer them would be forgotten and repaid a thousand times by the rare feelings I should have on their summits.

The party I was with listened very attentively to a gentleman who spoke of his nephew having climbed some minor peaks, and of how he intended trying the ascent of Mont Blanc. $\mathrm{He}$ impressed me with the idea that it was a wonderful feat to climb Mont Blanc, and this confirmed the magazine articles I had read. The whole 


\section{My Climbing Adventures}

atmosphere of my surroundings seemed to challenge all that was in me to try conclusions with these giants of the Alps, which made me vow that I would some day conquer Mont Blanc or die in the attempt. Without knowing it, I had contracted mountain fever, which was destined to lead me into all kinds of adventurous climbing and exploration at times which suited me, though they were often the most dangerous times to climb the mountains. I had gone up Mount Pilatus and the Rigi as a Polytechnic tourist, but I ran down Pilatus in two and a half hours and landed at its base a mountaineer in spirit and desires. Since that day I have tackled every shade of rock-, ice-, and snow-climbing, from the most dangerous miniature - rock acrobatic climbs to exploration through unknown country and mountains. My experience has been gained at very considerable risk, and in the moments when more practical feelings take the place of the longing for the mountains, I wonder what in the world led me into such difficult undertakings at the most dangerous times of the year. My only excuse is that I am, and always have been during my climbing career, a very busy commercial man, visiting Siberia, New Zealand, South America, 16 


\section{My Novice Stage}

and other countries on business, and have had to snatch my holidays at the time most convenient to my business; and although it would take any ordinary man about two years to visit the different countries and climb as much as I have done, I don't think it has cost me more time than a man in my position would take for his holidays. If I had waited for fine weather it would have interfered with my business, and I have never been able to afford this; and I can honestly say that my climbing has never been allowed to interfere with business. When you think of the enormous extra risks one takes in tackling a country and mountains in remote Siberia in winter, compared with summer conditions, you will naturally expect that this book will be full of narrow escapes and anxious moments, not experienced by the ordinary mountain-climber or explorer, who would not risk the climb in the off-season or climb in unfavourable weather.

You must please remember that when I started on these climbs I was full of confidence and hope of success without undue risk; but if I had known what I would have to go through, I should have decided that it was not right for a married man to take such risks which, in many cases, took all 


\section{My Climbing Adventures}

the pleasure away, and gave me, instead, that unreasonable, unsatisfying thirst for adventure which leads to fatal results.

Stimulated by the very encouraging reviews of my last book on Siberia, my publisher has invited me to offer to the public this further description of some of my climbs; and being painfully conscious that one mountain climb is very much like another, and becomes very quickly tiresome, I shall endeavour to leave out anything which I may consider too detailed. Some of my important climbs have appeared in magazine form before, but there are a good many very interesting incidents omitted which will give me material to give an account from a different aspect. My only aims in this book are to warn the climber against attempting climbs in bad weather, to show the novice the real dangers of Swiss and other mountain-climbing, and to leave on record some descriptions of lucky escapes out of places where nobody, but a "Mountain Maniac" would allow the fever to lead him.

To climb a mountain successfully with the minimum of risk, one must climb the mountain in ideal weather and in its best condition. My first climb was Mont Blanc (I 5,784 feet), the highest 


\section{My Novice Stage}

in Europe; it was fortunately climbed in good weather. Snatching a brief holiday, I reached Chamonix, 7th September I898, and after a trip over the Mer-de-Glace glacier and a climb up the Aiguille du Dru to about 9000 feet, I felt myself in good condition. The beautiful sunrise on the morning of 8th September 1898 illuminated Mont Blanc to such an extent that, by the aid of the telescope, I could almost distinguish the beaten path up which Frederick Payot, Joseph Couttet and myself intended to climb the following morning. We left Chamonix at IO.IO A.M., and the hotel guests, knowing it was my first climb, made the departure quite an important event by making a fuss of us.

We strolled casually up to Pierre Pointue, in company with E. S. Halford, a well-known Alpine climber. After lunch, Mr Halford tried my ability on some rock on our way to Pierre à l'Echelle, and we parted where our track leaves the mule-path, on which he continued to climb the Aiguille du Midi, the needle-tipped peak next to Mont Blanc. We turned down on to the Glacier des Bossons, and I came in close contact with those crevasses which had, up to now, only looked like streaks of blue from the Chamonix valley, and which looked 


\section{My Climbing Adventures}

like treacherous fissures from Pierre Pointue and the mule-path to Pierre à l'Echelle.

It was a hot day, and the glacier gave us a cooler atmosphere and made the easy first half of the glacier a most refreshing walk. The cracks or small crevasses were usually filled with a beautiful, pure, blue-looking water, tempting to drink. Halfway across to the Grands-Mulets we roped together, and began jumping, striding, and step-cutting to get across the crevasses.

The climax to the route we took was just where the Glacier de Taconnaz and the Glacier des Bossons meet.

Ice meets on its journey from two directions, and this pressure, helped by a rocky, uneven bed, produces séracs and pinnacles of all shapes and sizes, some of the largest 60 to 80 feet high, and 30 to 40 feet thick. All the snow-bridges were badly melted and the ice very rotten, owing to a very hot, cloudless summer in the high Alps; this made it very careful work. The crevasses are 50 to 500 feet deep, but the average deep crevasses are not more than 50 feet. I intended reaching the summit as quickly as possible, so we took a more difficult straight course across the glacier, instead of going a long way round to evade the difficulties. 


\section{My Novice Stage}

The crevasses are a beautiful light blue on the top and develop into a darker blue the deeper they are, until those which are very deep look black at the farthest depth the eye can see.

There are cracks a little way down, some of the wide ones revealing further crevasses in different directions at different angles, from 30 to 50 degrees of a slant under the ice. Nearing the GrandsMulets, two planks with strips of wood across and a ladder make it a simple matter to finish the roughest part leading to the rocks, up which we climbed to the Grands-Mulets. The hut at the Grands-Mulets is more expensive than Hotel Belmont, the Waldorf Astoria New York, or the most expensive hotel in the world, and the accommodation is as uncomfortable as the tariff is high. It is only 10,000 feet up on the Glacier des Bossons, but you would think the hut was 20,000 feet up on the Himalayas or some impossible place. The view of the sunset from the Grands-Mulets is very hard to equal on any mountain in Switzerland for a close view. The hotels and châlets of Chamonix were lit up just before the shadow rose quickly, followed by darkness, which caused Mont Blanc to drop back in the distance as though a hundred miles away. The shadow at one time rose 4000 


\section{My Climbing Adventures}

feet in one and a half minutes. Just as we were retiring we heard a cry for help below the GrandsMulets rocks. Our guide went down with a lantern, and found a porter had lost his way on the glacier. That was no rare occurrence, as the glacier changes so much. The hut-keeper burnt a red light, which was answered by a similar light in the Chamonix. Whether it was to indicate that all was well with the tourists, or to indicate that he was making plenty of money, and business was good, I don't know. There was a Belgian lady with two guides, and a German doctor with two guides, then later in the evening two Italian officers and two guides put in an appearance. We retired to rest early, but were prevented from sleeping by the constant noises of guides and porters, who were having a good spree on the liquor so necessary to the guide, according to his ideas.

We were up and preparing to start about two o'clock in the morning. The two I talian officers were just starting, and one remarked to me that they would be on the summit before us. I said: "We will see about that." The ice-slope across the Glacier de Taconnaz, which is an incline of 30 to 40 degrees, was treated with respect in the dim light of early morning, because it had a frozen 


\section{My Novice Stage}

surface and the crevasses were deep and numerous. We had to cut steps down one side of crevasses and up the opposite side. The pyramids of ice were so immense in some places that we stopped even on the edge of crevasses to look at them; you could imagine bears, wolves, lions, ships and all kinds of things figured on these séracs and pyramids.

Avalanches had shot across our path and the sight of one or two made us move quickly. The snow-bridges caused by these fresh avalanches were not too secure, so we distributed our weight over as much surface as possible by crawling on our hands and knees. Surely we showed enough respect to Mont Blanc in such a humble attitude. The leading guide sounded the snow with his ice-axe, but the method is not too good and cannot be relied upon, as we found by a weakening tendency of one or two of them while in the very middle. A steep incline along a zigzag route brought us to the Petit Plateau, which might be called a small mountain basin for the reception of avalanches, which come thundering from the Dôme du Goûter at the most unexpected moments. The guide pointed out the place where Herr Rothe and Michel Simond were swept into a crevasse and killed on 2 Ist August 


\section{My Climbing Adventures}

I89i. The crevasse was large enough to swallow a house.

After leaving the Petit Plateau we climbed a steep slope of ice and snow, about 45 degrees, looking steeper in the pale moonlight. We decided on early breakfast, but my bottle of tea, being carried on the outside of the guide's rucksack, had frozen into a block of ice. The two bottles of wine for the guides had been placed in the middle of the rucksack, next to the guide's back, to prevent them freezing. I had to be content with the pleasure of seeing the bottle of tea shoot over a precipice. We reached the Grand Plateau at 4.5 A.M., 1 2,000 feet above sea-level. This is a very large basin of snow, nearly flat, about 300 to 400 square yards, also very much exposed to avalanches. It was very trying for me to keep my eyes open, and I was quite indifferent about the avalanches. The air is very close and rarefied. From the top of the Plateau we saw the change from dawn into day. There was a straight line across in the direction of Chamonix valley, which divided twilight from day. Sun and moon's light had met, and the moon was making a feeble effort to hold its ground; but the sun lit up the summit of Mont Blanc and the line vanished before we could realise it; this brought 


\section{My Novice Stage}

the summit of Mont Blanc very near, and we hurried on to the hut (14,321 feet), built near the Dôme du Gouter (I4,2 Io feet). The want of sleep, the hurrying and the rarity of the air made me more thirsty than I should have been, and this began to tell on me, so we made a short stay sitting near the hut.

The thought of the Italian officers came to my mind and stimulated me to push on up the Bosses du Dromadaire (called by this name because they represent the two humps on a dromedary's back). We hurried up the last slope to the summit of Mont Blanc, and were pleased that the Italian officers had not arrived. The Observatory was unlocked by a key which my guide had. I climbed the stairs and stood on the top of the railings. This made me considerably over I 5,800 feet above the sea-level. We heard the cannon give us three salutes in reply to a wave of my handkerchief. Our speed over the Bosses du Dromadaire and up the last part of Mont Blanc was increased, because we knew the whole of the numerous telescopes in Chamonix had a throng of eager sightseers behind them, watching our movements; but for this we would not have reached the summit by 8.30 A.M., exactly six hours from Grands-Mulets to the 


\section{My Climbing Adventures}

Observatory, or eleven hours twenty minutes from Chamonix, actual climbing without counting stops.

I slept in the Observatory some considerable time before I was aroused by the Italian officers shouting in good English-"Bravo, Englishman, you won all right." We had tea (made of snow water) together, and they started off down again, while I stayed to admire the view.

The foundation of the Observatory is on snow, at a height of 15,784 feet, and will one day slip down the mountain and leave the summit unvulgarised once more. It contains all kinds of instruments, which are nearly always out of order, and for all the good I have ever heard coming from it, it might better suit the lower Alps for a goat- or cowshed.

The summit of Mont Blanc is rather too high above other peaks to enable one to realise the grandeur of the precipices and snow slopes of the mountains all around.

It is as though the Aiguilles of the Mont Blanc range were columns and pillars for the purpose of supporting a dome of snow 2000 to 3000 feet higher than themselves. It has the advantages of a mountain-range view of a most magnificent description, and in this respect it well repays one. 


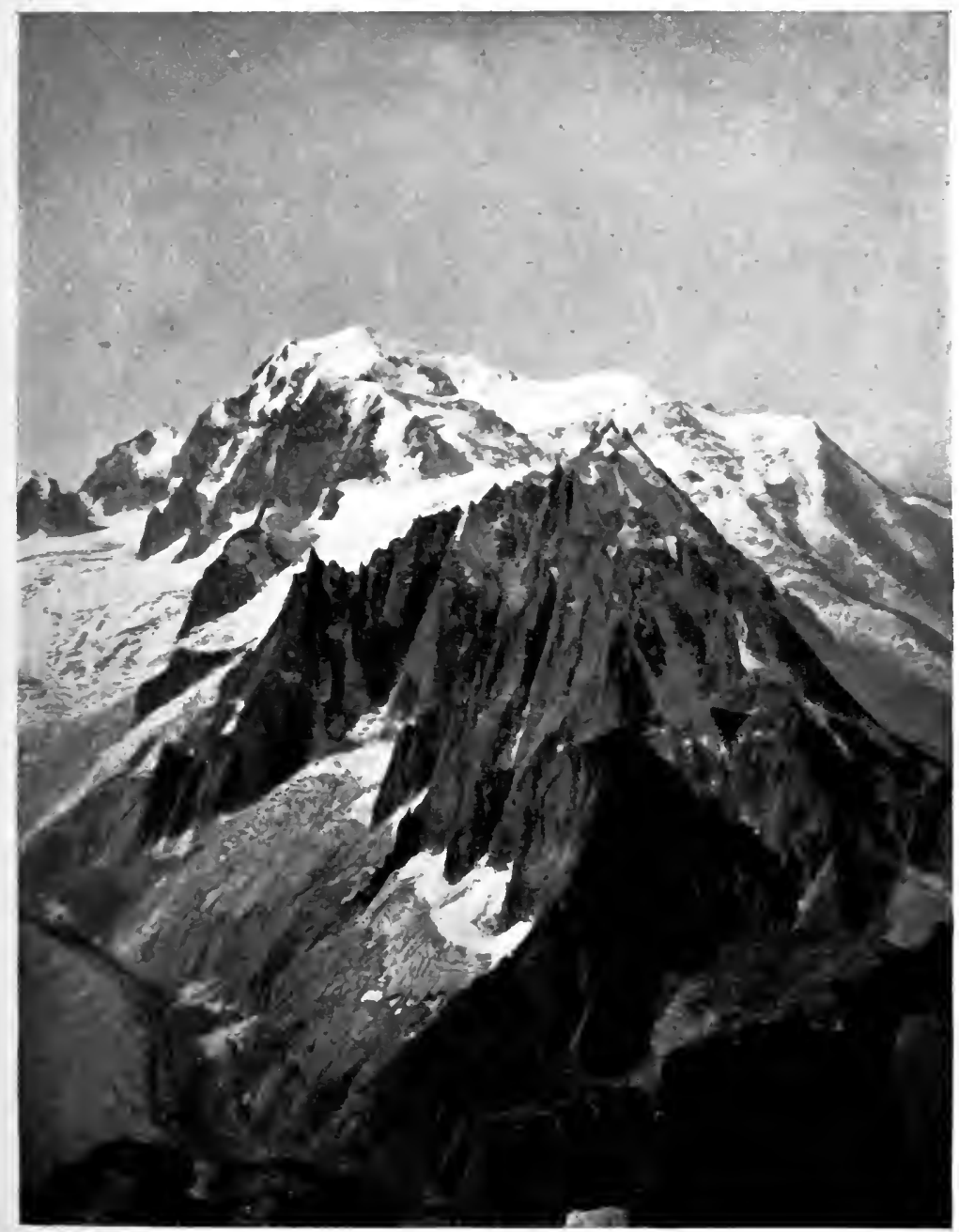

AIGUILLE DES CHARMOZ, AND MONT BLANC IN THE BACKGROEND. 


\section{My Novice Stage}

There are only a few mountains in all the European Alps which give one this view of ranges of mountains in every direction; while there are hundreds of minor peaks where one can see the adjacent mountains to much better advantage. The range view is the best from Mont Blanc for the European Alps, as it very often is from the highest mountain in any mountain system; it will always, therefore, prove a source of special attraction to the climber, because the view from the summit of the mountain is always one of the attractions of a climb.

Lake Geneva looked a very small, crescentshaped lake about 2 to 3 miles long, while it is about 56 miles long. Chamonix looked like a lot of black specks of mud in a green valley, and a streak of white cotton down the centre of the valley appeared in place of the mountain torrent.

Standing on my first conquered summit, the difficulty of the climb seemed nothing, and the dreaded Mont Blanc was gone for ever; but, unlike most successes one realises, which suddenly grow commonplace and very familiar, the summit of Mont Blanc retained for me that fascination and mystery which possessed me after the view from Pilatus. The impression left with me after stand- 


\section{My Climbing Adventures}

ing on the summit of Mont Blanc was enough to make my growing mountain fever still more intense ; and it did. We roped together at II.30 A.M. and commenced the descent.

I was surprised on reaching the hut to find it was taken down ready for removal, because it was slipping down the mountain. This lowered my idea of the great feat of climbing Mont Blanc: all these supposed dangers had been undertaken to remove a hut. I had looked up the records and found 1656 climbs had been made in about one hundred and twenty years, but I soon came to see that these officially-recorded climbs were those which had paid heavily for the privilege, and had been started from and received back into Chamonix.

We glissaded down the steep slope into the Grand Plateau and hurried across it without a word, and more standing glissading brought us to the Petit Plateau; from here we were compelled to go carefully by the side and across crevasses, until we reached the most difficult part of the Glacier de Taconnaz, with its huge blocks of ice. Jumping many crevasses and taking a zigzag course, brought us to the most practical way to the Grands-Mulets. The glacier round the rocks of the Grands-Mulets presses itself into pieces, over which there is no 


\section{My Novice Stage}

possible route, and the ordinary route up Mont Blanc is made much longer by having to go down the centre of the glacier, half a mile away from the hut, and then suddenly turn to the right.

After lunch the Belgian lady asked me to watch her and her guides and see she got safe to Chamonix. They kept about 20 yards ahead of us. They had not gone far before her porter slipped into a crevasse, pulling her to her knees. The guide behind her pushed his ice-axe into the snow and prevented the party slipping in. We ran down and round to the other side, expecting to see the porter hurt, but he was undamaged, and swinging like a pendulum from one side to the other in his hopeless attempts to dig his feet into the side. We unroped and lowered our rope to him; he tied our rope round his waist, and loosened their rope as we pulled him up a little. Once he was free from their rope, we hauled him out. The whole of the time this was being done, the guides and the porter in the crevasse were joking one with the other. This incident did still more to lower my opinion of the feat of climbing across crevasses. It also gave courage to the lady, and we made very much better time.

We narrowly escaped a rock avalanche, which 


\section{My Climbing Adventures}

was coming down from the Aiguille du Midi. After this we unroped; I bade the lady good-day, and we hurried down to Chamonix. That journey made me begin to love the mountains, but I came down feeling it was not so difficult to climb Mont Blanc as I had imagined, and that, given fine weather, it was only a long snow and ice trudge; all the danger had been taken away by the security of three of us being tied together by the rope. Mont Blanc is the most deadly mountain in bad weather. It is the only mountain in the world that has claimed eleven victims in one tragedy, near its summit, too; showing very plainly that you are really at the mercy of the mountain. Many parties have lost their lives owing to miscalculating in the clear air the distance to the next hut, and thinking they could get there before the storm commenced.

We were given a reception on getting back to Chamonix, and after that climb non-climbers looked upon me as a climber, and I had made my mind up to become an expert mountaineer. After a few minor climbs I left Chamonix, feeling that when I returned to tackle the mountains I should no longer be considered a novice. I had the date of the climb and the mountain's name burnt in my ice-axe, to indicate I had ascended the highest mountain in 


\section{My Novice Stage}

Europe. I took and paid for a certificate from the chief guide's office, and I felt that this completed the novice stage of my climbing, and that I had carried out all the formalities which seem ridiculous in after years. 


\section{CHAPTER II}

MOUNTAIN CLIMBING IN THE SECOND DEGREE OF DIFFICULTY-ASCENT OF MATTERHORN IN RECORD TIME - I CLIMB MONTE ROSA WITH A NOVICE, MAKING IT A DANGEROUS CLIMB

THE Matterhorn and Monte Rosa are about 1 the second degree of difficulty in Swiss climbing, a distinct step above the novice stage.

I journeyed to Zermatt via the Gemmi Pass on September 1 899, accompanied by Mr A. B. Holmes, Buxton. Arriving in Zermatt in the evening, I started for the Matterhorn at I 2.5 midnight the same evening. I had read about a record climb of the Matterhorn and wished to beat it. I had seen the Matterhorn from the summit of the Gemmi Pass, and I had another view or two on my way to Zermatt.

The guide I had engaged by letter from England, and had selected a porter at Visp; this explains how we were able to rush to the mountain the same evening. An old guide at Hotel Monte Rosa acted as timekeeper, and we commenced the 


\section{More Difficult Climbs}

journey through the village, round the churchyard, and made a good pace up to the Schwarzsee Hotel, resting here for a drink of cold tea. Pushing on over the rough, stony path, we reached the Hornli ridge, and were soon at the Matterhorn hut enjoying some soup.

Climbing down the ridge towards the actual peak, we were enabled to get on to one of the ridges of the Matterhorn. I was surprised to find fairly broad ledges where I expected, looking from the Schwarzsee Hotel, only precipices; this taught me that mountains look more precipitous seen from the distance. We turned to the left along a ledge of rock, getting an occasional glimpse of the pale moon through fast-fleeting clouds. Turning towards the main ridge, we climbed steep rocks in that direction for about 600 feet. Again turning to the left we passed over loose stones (a sign of avalanches) and came to the large couloir. We carefully cut our steps up for about 500 feet to round the overhanging rocks; we crossed several snow gullies and arrived at the old cabin (now out of use except as a storm shelter), where we enjoyed an early breakfast. The first signs of sunrise coming from the direction of Monte Rosa gave me a most unique panorama. We had a splendid view 


\section{My Climbing Adventures}

of a large number of the monarchs of the Alps, I 3,500 to I 5, 2 I 7 feet, the highest summit of Monte Rosa.

The wind made music amongst the rocks of the Matterhorn, and it became a very wild, threatening morning: this spurred us on up the steep rocks leading to the main ridge again; here we had grit as well as wind blown into our faces, until we did not take advantage of all the hand-holes.

We were very early at so high an altitude, and some of the ice remained in the cracks and crevasses, which, with the wind, made it very difficult. We decided upon climbing steeper rocks off the main ridge for some distance. We looked forward to and hoped for better conditions before climbing the shoulder, and when we reached the shoulder we rested under it for three-quarters of an hour, hoping the wind would stop. Dr Murett, of the Lausanne University, with his two guides, overtook us under the shoulder and seemed to bring better weather, so we proceeded with all possible speed up the vertical rocks to the shoulder, the most exposed part of the Matterhorn, a peculiarly awkward slope. The snow has a resting-place, and there are railings near the top of the shoulder. I took two snapshots of $\mathrm{Dr}$ Murett and his guides while they were 34 

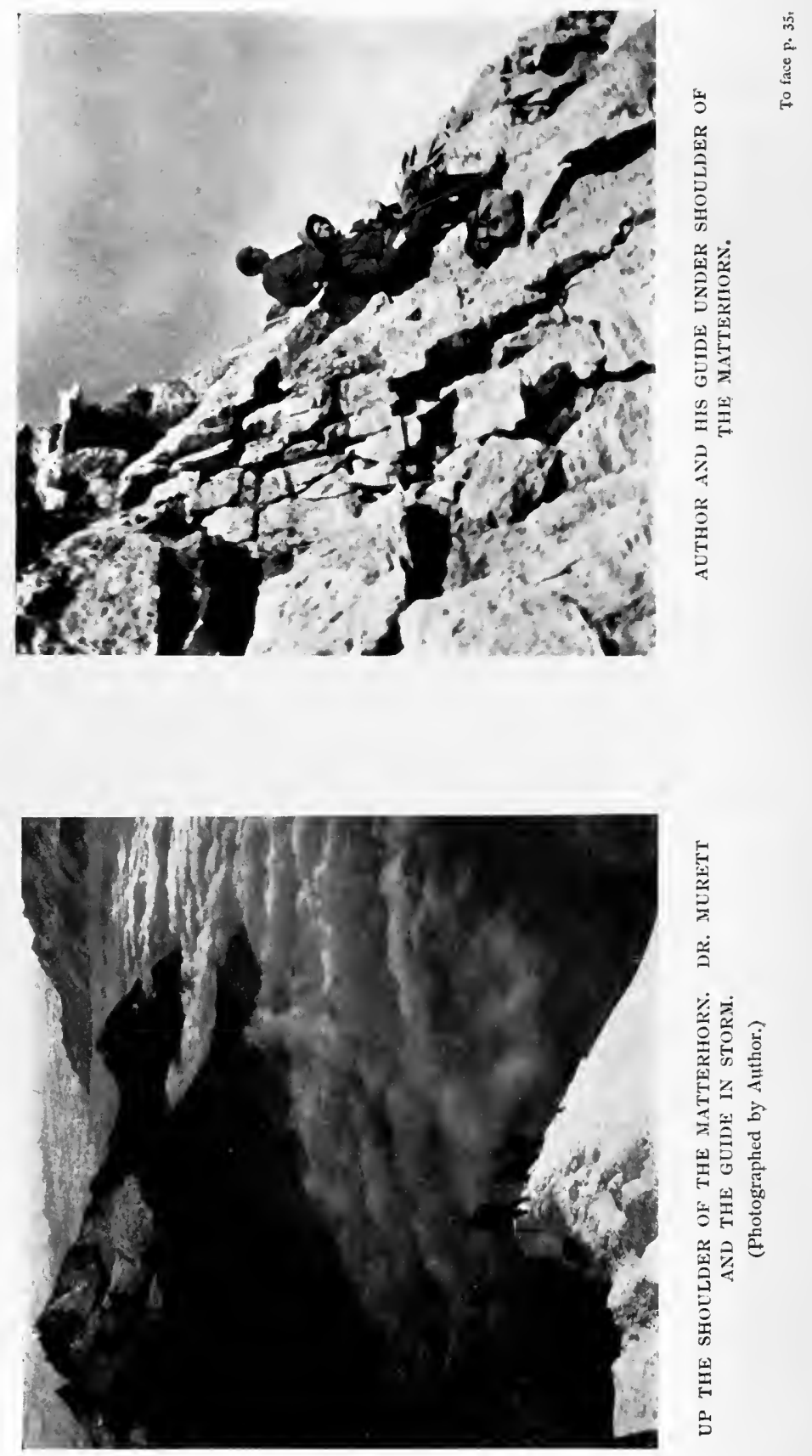


\section{More Difficult Climbs}

climbing the shoulder in the gale. The photographs came out well, showing the clouds 3000 feet below the shoulder, extending to the Bernese Oberland on one side and Monte Viso in Italy on the other side. We felt the full force of the wind here, and the Doctor lost his hat. Although the ropes attached to the mountains in some parts were found to be of little use, on account of their being untrustworthy and rotten, we found them acceptable when we had to stoop down on the shoulder to prevent being blown off. The top of the shoulder was the climax of the Matterhorn climb, and here the ropes and chains all helped us. We could not have proceeded in such weather but for them. While climbing above the shoulder I could see huge square blocks of ice broken away from the Matterhorn glacier 4000 feet below.

We could see about 4000 feet down the other side of the glacier some of the narrow pieces of rock lying over cracks which required very careful climbing over underneath. We continually had an uninterrupted view of both sides of the mountain. Climbing the last few hundred feet with a great amount of satisfaction, we stood on the summit of the Matterhorn, despite the storm, at about 8.30 A.M. 


\section{My Climbing Adventures}

The Matterhorn is one of the most impressive mountains in the world, on account of its apparent obelisk; and the summit is as exposed as any summit. The mountains around seem very fierce, and the precipices most vertical. The position is similar to being up in a balloon, just like standing up in the air, and next to Mont Blanc it is as good a mountain from which to see the mountainsystem of the Alps as one can imagine. I could see Mont Blanc summit I 20 miles away, just as I had seen the Matterhorn from Mont Blanc, and although Mont Blanc was the furthest object I could distinguish, I have no doubt but that I could have seen Mont Blanc if it had been 150 miles away. We walked from one summit to another very carefully, being still roped together, and I placed my card in a bottle in the usual way, and stood to try and take in the view. It is not easy to make the mind grasp the distances and the depth of precipices and the size of the peaks all around; but by looking at the mountains for some little time this is realised, and one feels one's own insignificance, but with it an exceptional feeling of satisfaction and pleasure at having conquered the difficult precipices and ice slopes of the Matterhorn. The actual summit changes each 36 


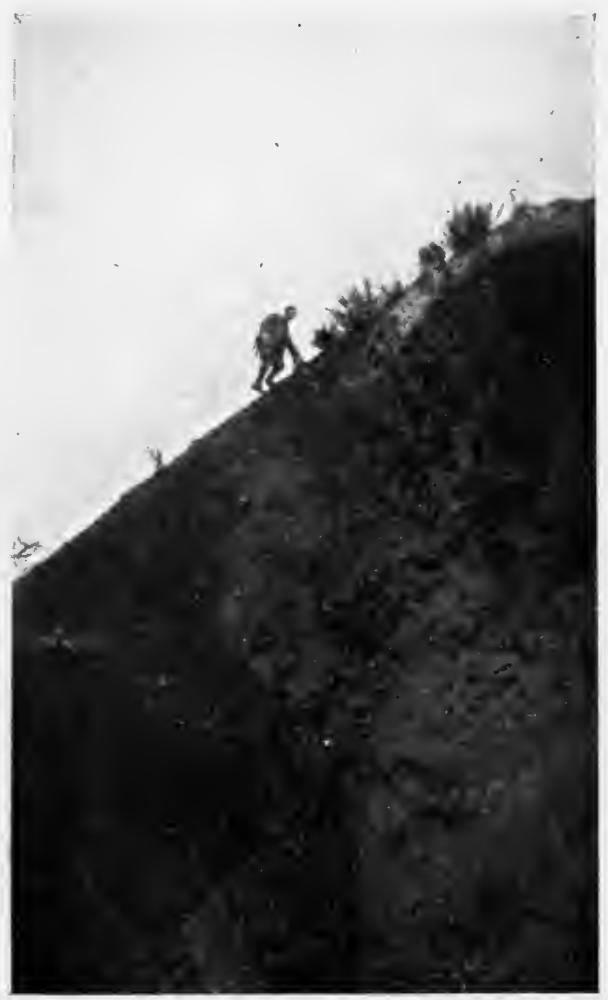

ALTHOR CLIMBS EASY SLOPES GARTH STONE QUARRY.

(Photo during his first climb) 


\section{,}





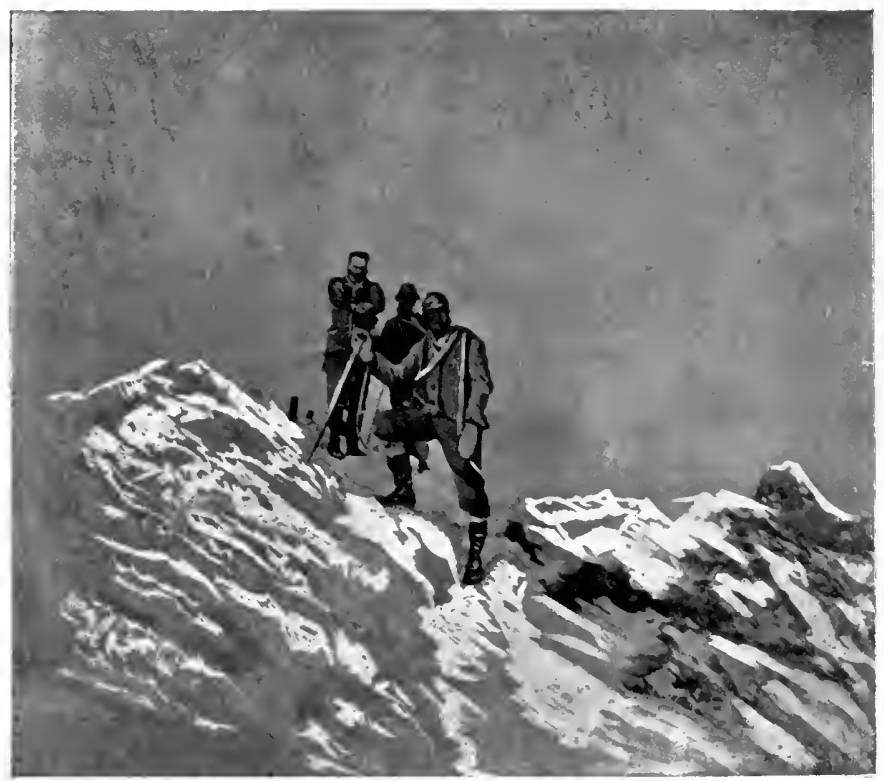

SUMMIT OF THE MATTERHORN.

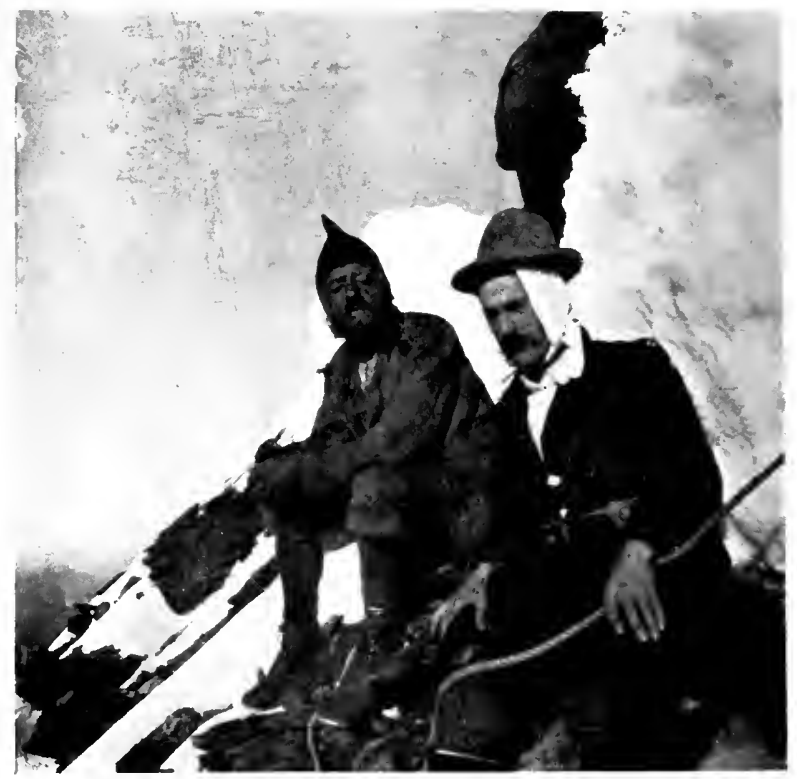

AUTHOR AND GLIDE. ITALIAN SIDE OF SUMUIT OF MATTERHORN. 


\section{More Difficult Climbs}

year, but when I stood on the top it was a Vshape, and in the photograph showing Dr Murett and his two guides on the summit the $\mathrm{V}$-shape is quite clear. We climbed over the snow of the summit on the Italian side, which was about 9 feet thick, and rested on the Italian side, while we were anchored to two ice-axes pushed into the snow on the summit, and the rope wound round. Our porter gave us a Swiss warbling song, and we had a pleasant time, cut short by severe gusts of wind and snow blown over the summit. The guides knew we were in for a storm, and we quickly climbed to the summit, where we got the full force of the gale and could hardly stand. We had passed two guides and a climber who were coming off the Matterhorn, having given it up as hopeless in such weather. Just as we had commenced our climb at this point I thought them wise men.

The storm delayed our progress, although we forced ourselves through it. The wind was coming up the mountain in a fierce hurricane, blowing grit and hard snow 20 to 30 feet above the summit from the Swiss side. We had to climb in a crouched position most of the time, with the face towards the rock. While in this stooping posi- 


\section{My Climbing Adventures}

tion I could distinguish clearly that the forces of Nature and this huge mountain of rock had been at war and the mountain had lost heavily; thousands of tons of moraine and huge rocks lying on the glacier, 7000 feet below, had been split off the Matterhorn by Nature's mountain-chisel, "Jack Frost." It was apparent that the danger of rockavalanches on the Matterhorn had been and was very serious. The cracks and fissures in the rock on the Matterhorn are so numerous that the mountain looks like a pile of ruins. The snow melted by the sun lodges in these cracks, freezes. at night, expanding during the freezing and bursts the rock, which breaks away from the ice grip when the sun thaws that ice. This process going on for thousands of years is the same law of Nature that is at work making the mountains of the world gradually fill up the valleys; the glaciers helping this agency by carrying huge boulders miles away from the mountain. When we were climbing down the steep rocks above the shoulder in this storm, the spot where the Whympers' accident occurred was climbed down with special caution. One source of danger on the Matterhorn is that the slopes of rock in many places are not steep. enough to climb down face towards the rock, and 38 


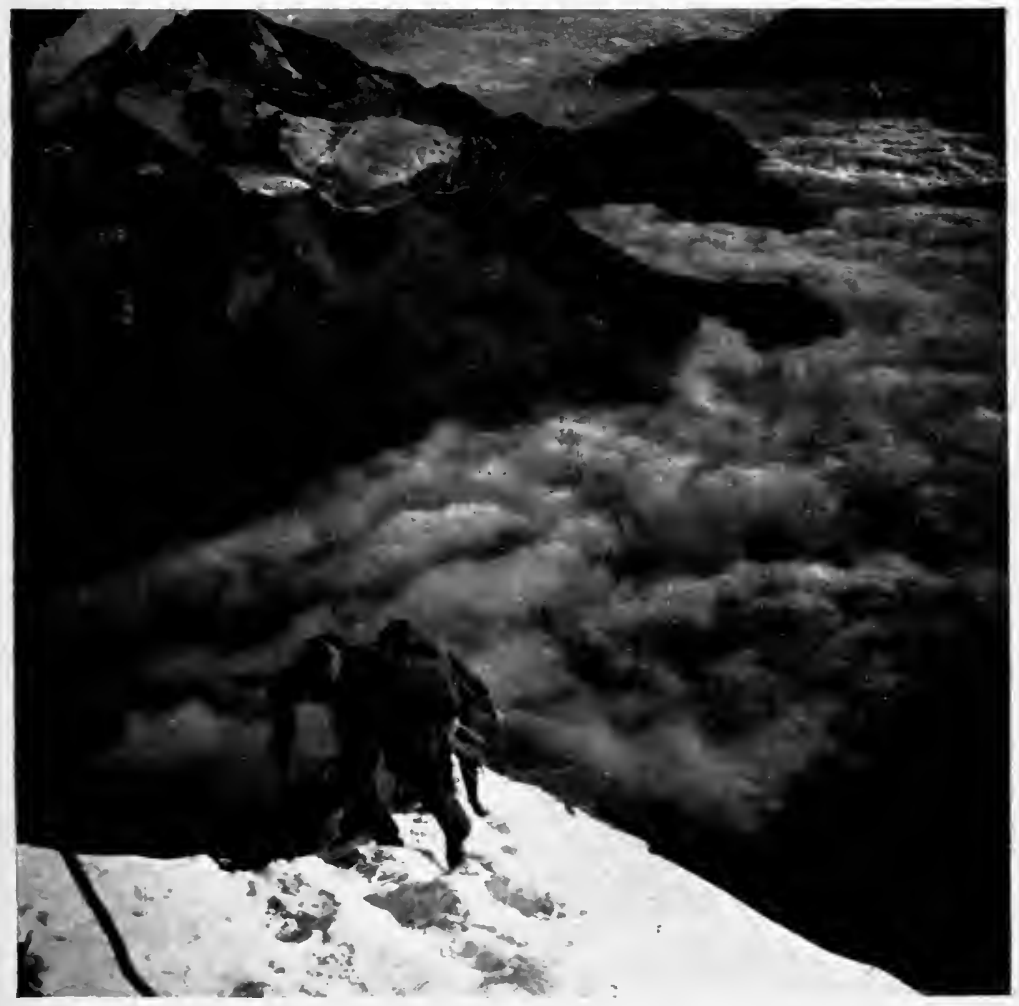

PARTY IN STORM, TOP OF SHOULDER OF MATTERHORN (14,0OO FEET ABOVE SEA LEVEL), CLOUdS 3,000 FEET BELOW. 


\section{More Difficult Climbs}

not easy slope enough to walk down, and no doubt that may have had something to do with the Matterhorn accident. The party might have climbed down face towards the rock with much more safety than walking down in the way they did. I cannot feel proud of the way we slid and crawled down and over the Matterhorn shoulder. We thanked the brave guides who had placed ropes and chains on the Matterhorn. We had disdained to use them on the way up, until the storm made us, but now the storm had increased to a blizzard, and we had to catch hold of anything to prevent ourselves being blown off.

Fresh snow had covered. up most of the ropes and chains, but I had just got a grip of the chain near where the shoulder finishes when the porter slipped and nearly jerked me and himself off the mountain. He was twenty or thirty seconds before he could turn himself round and get a grip of the rocks again, but after the first jerk 1 had tightened my grip on the chain. This was the climax to a number of slips. From here we climbed much more carefully, despite the storm.

It was causing the sightseers in Zermatt very great concern to see us struggling with the storm, and we were told that every telescope was eagerly 


\section{My Climbing Adventures}

trained on to us until we descended through some clouds which had enveloped us. Once off the exposed shoulder we jumped down the Matterhorn ledges, as though we had been on a broad path. We steadied ourselves while cutting our steps down the ice slope, until we heard an avalanche coming down, and we rushed the last 20 or 30 feet over almost obliterated ice steps. Some of the avalanche shot over our heads, and some came down the ice slope and obliterated the ice steps we had cut a few minutes before. While we paused, my guide found a pipe and cap, which turned out to belong to the guide Zurrier, who had been killed one month before by a rock-avalanche on this same couloir. Both the pipe and cap were placed in the Zermatt Museum, which is full of relics of disasters. Looking up for more avalanches, we could see snow and pieces of ice being blown up over the summit at a furious rate. We hurried down and round the precipices, until we reached the narrow divide that enabled us to climb on to Hornli ridge. I left one of the guides at the Matterhorn hut to bring our rucksacks, etc., and hurried along to the Schwarzsee with Tangwald. He said that Mr Binns, who had beaten the record which I was trying to lower, had left him with 


\section{More Difficult Climbs}

a bottle of wine and completed the journey to Zermatt himself. I had to do likewise, and it was not long before I reached Zermatt, running down the latter part of the journey. Not counting the stay at the Matterhorn hut on the way up in the same way as the previous record-breaker, I had completed the climb up and down in twelve hours and thirty-five minutes. This was one hour faster than the fastest time on record under similar conditions for stops.

I had gained an experience of rock-climbing, owing to that storm, very much like that of a man who finds himself thrown into deep water before he has learnt to swim. It was like concentrated years of practice and experience. A novice overlooks little cracks and holes where he could get a grip or a footing, but the expert climber has trained a faculty which is so used to seeing the possible hand- and foot-holds, that he uses them as though by instinct. The storm threatening to blow me off made me see every possible help on the rock, and taught me the value of every little crack or possible hold by hand or foot. The Matterhorn under favourable conditions may be much easier than it was when I climbed it, but I am sure that it is only a 


\section{My Climbing Adventures}

mountain that a good climber should tackle. The novice will do well not to take any notice of anyone who makes light of the Matterhorn. It has not become easier than when the Whymper and other accidents occurred on it, and these accidents have mostly been owing to the difficulties and dangers of the mountain, and not like Mont Blanc fatalities, which have chiefly been owing to the bad weather, making the climber helpless and quite at the mercy of the enormous snow-fields.

All Arctic and Antarctic climbers should climb Mont Blanc for practice, to enable them to know how to tackle crevasses and discover snow-covered crevasses.

Since my rush up and forced rush down the Matterhorn, my idea is that it is a mistake to go for speed unless caught in a storm.

It is even a mistake to climb any mountain unless you can tackle it at the most favourable time.

I will next take my climb of Monte Rosa, with the object of showing how some people get to the summits of the Alps. There are climbers who only need a guide to show them the route up a mountain and a porter to do the carrying work, 


\section{More Difficult Climbs}

and both to be roped to the climber to make the maximum of safety on a glacier or mountain ; there are other climbers who would need an occasional pull at the rope or a confidence-giving word at the right time; but there is the would-be climber, who knows he does not possess the stamina or ability to do anything but be dragged up.

The climber, although a novice, may be a good athlete and able to climb the mountain with occasional help; but most novices are useless, and are simply hauled up the mountain. My climb of Monte Rosa was with a novice of the useless type, and it will probably serve as a caution to climbers against selecting their climbing companions too casually. I am convinced that most of the accidents occur owing to the novice in the party.

My friend Holmes took the two guides with whom I climbed the Matterhorn, and went to climb Monte Rosa the day after the Matterhorn climb. I intended to have a rest that day, but about midday I could not resist putting on my climbing-suit and boots and taking my ice-axe with me for company up to the Gorner Grat to meet my friend. While waiting at the Gorner Grat a Dutchman of Amsterdam said "he had watched me run down the last part of the Matterhorn the day previous, 


\section{My Climbing Adventures}

and had a good opinion of my climbing ability, and as he intended climbing Monte Rosa, he would be delighted if I would join him and have the free use of his guides." I looked upon this as a chance of a lifetime, as I was a poorer man in those days, and it meant saving about $£$ I 2 . I gladly accepted his kind offer, on condition that I met my friend Holmes and got back some of the things I had lent him to complete his kit.

I met my friend and he gave me a dreadful account of the knife-like ridge of Monte Rosa, and said he would not advise me to go, and that they were lucky to come back safely. This spurred me on, instead of deterring me; and I hurried after and overtook the Dutchman's party, more than half-way across the Gorner Glacier.

I naturally thought the Dutchman a good climber; there was nothing to indicate the novice about him, but I had not gone very far with him before he began to place his feet on the thin ice instead of the small hillocks of thick ice on the Gorner Glacier. I was quite astonished but put it down to carelessness, and so we landed at the cabin.

After early dinner we witnessed a lovely sunset and turned in to prepare for bed. The Dutch44 


\section{More Difficult Climbs}

man seemed to be anxious about the mountain, and asked the guides and myself questions which forced the fact on my mind that he was a novice. I awoke a time or two during the seven hours' sleep we allotted ourselves, but each time the Dutchman was tossing about and could not get to sleep.

We prepared to start at two o'clock in the morning. The weather was fine but very cold, even for a September morning (that year 1899 was a rather early winter in the Alps). As we started up the long slope of Monte Rosa the Dutchman complained about the cold and put a long overcoat on; this was one of the things which accounted for the very slow speed he climbed at. We had not gone far before the frost got hold of my toes, and I asked the guides to try and quicken the pace, but they could not get the Dutchman to go any quicker. They commenced to pull him up. I expected him to get annoyed at this and quicken his pace, but he seemed to like it. I knew then we were in for a long journey before we reached the highest summit of Monte Rosa, Dufour Spitze, 15,217 feet, so I decided to make the best of it. We took double the customary time to climb the ice slope, but it taught me a lesson of c 


\section{My Climbing Adventures}

how to thoroughly enjoy the sunrise. I watched one peak after another of that great circle of mountains round Zermatt being lit up by the morning tint, until the sun lit up the ridge of Monte Rosa, and made the top of the slope we were climbing very much warmer. We managed to get the Dutchman along the ridge all right, but when we commenced the knife-like ice ridge leading up to Dufour Spitze summit, we had a most risky time. The Dutchman seemed to have lost all his will-power and, unable to climb at all, he had to be pulled up, just raising his feet to place them in the next ice step; one time he was pulled to his knees, and several times he looked to be on the point of overbalancing himself. One side of the ridge was the very steep ice slope leading to the Gorner Glacier; on the other side an almost vertical rocky slope leading to the Italian side. The drop on each side was 3000 to 4000 feet. What a fool I felt taking this risk for the sake of climbing Monte Rosa free. I had to act as a porter, steering and steadying the Dutchman, while the "mule-guides" did the tugging and hauling. On one or two occasions I very nearly jumped over the opposite side to that down which the Dutchman seemed to be tumbling, and I constantly 


\section{More Difficult Climbs}

took a glance over the ice edge to see if I could pick a decent place to jump on. The slope seemed very long, but we eventually landed on the top quite safely; then, to crown all, our Dutch friend wanted to go to sleep on the top ridge! I insisted upon taking him up with us rather than turn back. We trudged on again with only the ordinary difficulty of our load until we came to the first chimney. The bottom of the chimney overlooked the steep slope, and had to be climbed into, round the base of out-jutting rocks. We securely tied the Dutchman, the two guides climbed to the top of the chimney, and I steered while they hauled him up. This was about the limit. Here was our Dutch friend, $5 \mathrm{ft}$. I I in. in height and about 12 stone, being pulled up like a sack of flour by these two guides; and they got him to the top all right; I climbed it while they had a rest on the top, and after proceeding some little way we came to another chimney, which outjutted and overhung the broken glacier, 3000 feet below. After the same preliminaries, the guides climbed to the top of the chimney, but the Dutchman jibbed, and it was some time before we could persuade him to make for the base of the chimney. I was in a helpless position. If the rope had 


\section{My Climbing Adventures}

broken while scraping on the sharp rocks of the chimney, the guides would have been secure, but the Dutchman would have dropped to the bottom of that mountain, and I would have been pulled with him. I did not realise or think of this while on the ascent. After the second chimney there were only a few exposed rocks to scramble over, and we stood on the highest summit of Monte Rosa, I 5, 2 I 7 feet.

Besides taking in the view of the Italian lakes and hundreds of snow-capped peaks in all directions, I built the cairn higher, after placing my card under the rocks. The pole which stuck in the middle had a large tin can on the top, and as we could see some one on the snow slopes below, I rattled the tin can on the pole; but they did not signal in any way, so I presumed they could not hear. I secured one or two photos, but. my camera got out of order and prevented me winding the film on, so some useful snap-shots. were lost. The Dutchman had a sleep on the summit, and after about one hour of delightful views we commenced the descent. I took the lead down, and it only occurred to me what a. dangerous position I was in, as I stood on the precipice at the edge of the first chimney, hanging on by one hand to enable me to steer the Dutch- 

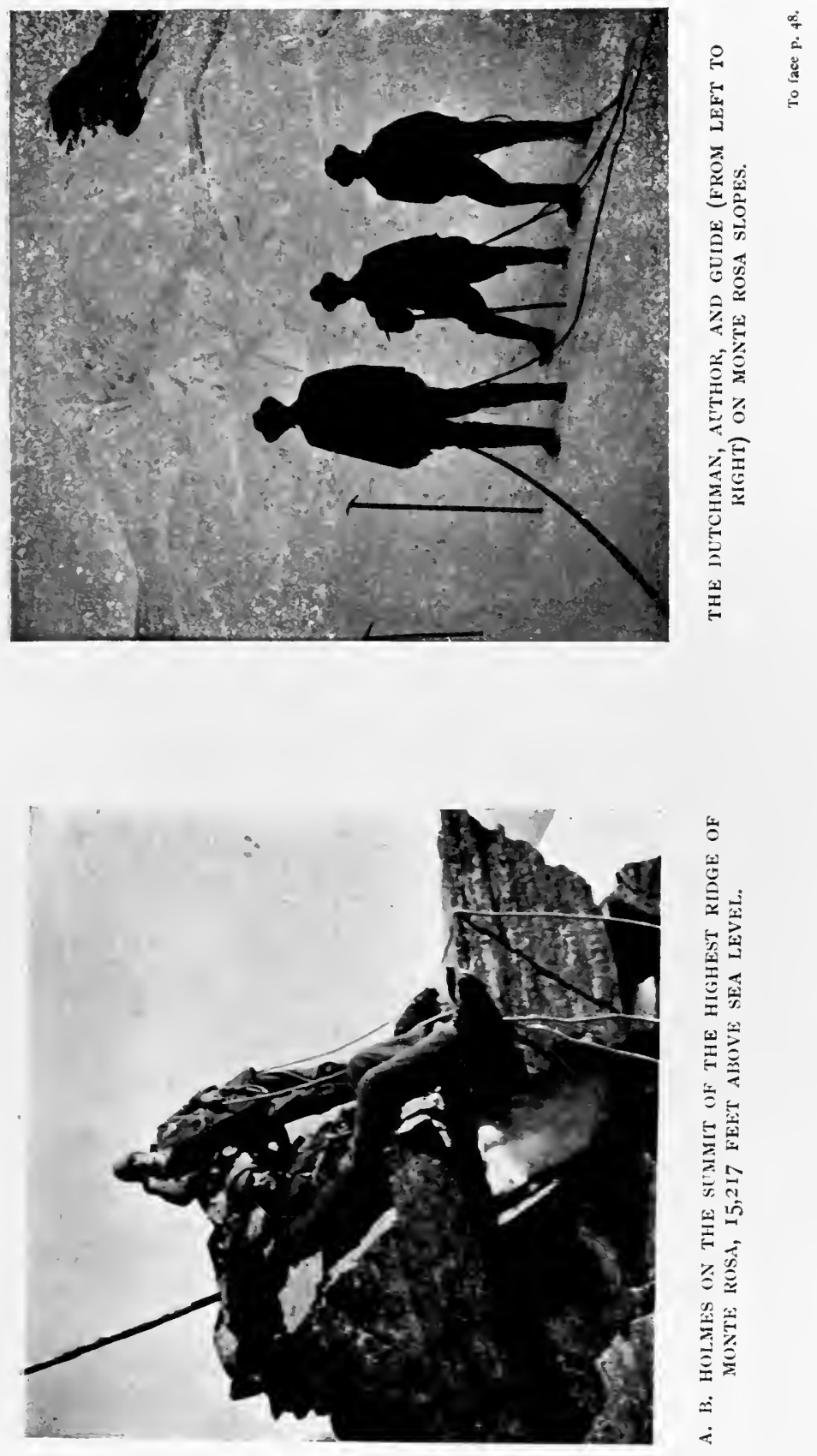



\section{More Difficult Climbs}

man on to the ledge from the chimney. I felt the chance of the rope being cut in the jagged, rocky chimney. While waiting at the bottom of the second chimney, I fastened the rope fairly securely round an out-jutting rock. We hastened down to the ice ridge, because it would have made it much more dangerous if the sun went down, and the steps on the ridge had a chance to freeze. During the climb down, with the exception of our friend sitting down a time or two and delaying our progress, there was nothing specially dangerous, and it was with light hearts we reached the first ridge at the top of the final slope.

After going some distance along the ridge, I suggested that we should glissade straight down, but the Dutchman thought it much too steep. He yielded to my persuasion, however, and we slid down at a good speed until we got so hopelessly mixed up that it stopped our progress. Then it was arranged that I should take the lead. The Dutchman was tied up with his long overcoat on, one guide steered by a rope attached to his waist and the other guide ran behind to put the brake on. It was getting late, and I was determined to sleep in Zermatt that night, so I galloped down the slope as fast as I could. 


\section{My Climbing Adventures}

The Dutchman liked it very much to start with, but as we neared the bottom the snow was only about 12 inches thick, and he rubbed it off and was dragged over sharp edges of small cracks in the ice; he shouted out to stop, but before we took notice of him and pulled up, the sharp, edges of ice had cut a hole through his overcoat and undercoat, etc. It hurt him very much, but he was awakened fully for the first time since we started the climb. Then he started scolding the guides. I asked Joseph Binen, the Dutchman's leading guide, why he took such risk. Putting out his hand, as though taking a grip of the Dutchman, he replied with a sneering sort of smile, "He could not tumble, I had him." He further explained that it was the Dutchman's first climb, and they had been engaged for one month on condition that they got him to the top of Monte Rosa. If they had failed, it would most probably have cut the engagement short, and they would have lost a valuable month's pay. This gave me an insight into the reason the ropes and chains are fixed on the Matterhorn, and the reason why helpless men and women and rucksacks reach the summit of some of the highest mountains in the Alps. It is a surprising thing that although 


\section{More Difficult Climbs}

there must be a large number of narrow escapes on the Alps, owing to the inability of climbers, one never hears about them. On the other hand, the mountain is generally made out to be easier than it really is by the individual who wants to make out how clever he is.

Alpine climbing is a form of competition amongst the 20,000 or 30,000 climbers in Europe, to see who is the best man in the following way: certain peaks require a certain amount of skill, and as there are many degrees of difficulty to be overcome, according to the mountain, it is only a very select few who are able to climb the most difficult of the Alps. There are other climbers who may differ with me, and pretend that they think too much of the mountains to allow any kind of competition to enter into such a noble craft, yet they will invariably say, So-and-so must be a first-class climber, he has climbed the Grépon, Aiguille des Grands Charmoz, or some other firstclass peak. From my knowledge of Alpine climbers, in different parts of the world, I believe that they are inspired to the best climbs because they feel and know that the "climb is the measure of the man." That is why the novice makes little of climbs which he has probably climbed with very great risk. 


\section{My Climbing Adventures}

I asked the Dutchman to excuse me, as I wanted to be in Zermatt for dinner, and I made very much better progress after leaving him. Running across the glacier and up the path to the Gorner Grat Station, I was just in time to catch the mountain train, and arrived back for late dinner in Zermatt. The Dutchman and his guides stayed at the mountain hut that night, and came on to Zermatt the following day, none the worse for his adventure. 


\section{CHAPTER III}

EXTRAORDINARY ROCK CLIMBS-CLIMBING WALNUT TREE "MATTERHORN"-ILAM ROCK CLIMB, DOVEDALE, DERBYSHIRE

TETURNED to England, after that Monte 1 Rosa climb, fully determined to have some practice on rocks. The way that Joseph Binen had climbed Monte Rosa, hauling up the Dutchman, made it plain to me that it was possible to develop rock- and ice-climbing ability which would make a difficult mountain easy. I had been lucky, or unlucky, enough to have had my last two climbs under most adverse conditions, which had taught me more than I might have learned in a dozen uneventful climbs; but I felt that I could make myself more capable by practising detailed rock climbing on any piece of rock where I could climb high enough for a fall to prove fatal. I climbed cliffs along the South Wales side of the Bristol Channel, outside Penarth, where I lived then. One day I took train to Walnut Tree Station, with the intention of walking over the Garth 


\section{My Climbing Adventures}

Mountain, but I saw some splendid rock climbs inside an old disused stone quarry, and I asked my wife to excuse me, while I tried one or two of them. The following Saturday afternoon I took a friend with me, and did the main climb, which was up the side of a piece of rock about 200 feet from the ground. To climb off the top it was necessary to climb down on some overhanging rocks. It made an exceptionally good miniaturerock climb, and I mentioned it to a friend of mine, $\mathrm{Mr}$ J. J. Neale, President of the Cardiff Naturalist Society. In a few days he asked me more about it, and declared that a $\mathrm{Mr}$ Thompson, an Alpine-climbing friend of his, of Penarth, in the company of two other gentlemen had climbed this rock; but they had rope, boots, and were all roped together; even with these helps they had found it very difficult, therefore he doubted my story about having climbed it by myself. I arranged with $\mathrm{Mr}$ J. J. Neale and his friend Thompson to come with me the following Saturday, so that I could prove that I had climbed it, by climbing it again. We arrived at Walnut Tree Station, but had to wait for it to stop raining; and by the time I was ready to climb we had a crowd of sightseers, including some quarrymen. I had 


\section{Extraordinary Rock Climbs}

climbed half up the most difficult way when a quarryman said he would be on the top before me. He scrambled up the smooth part of the rock, which was at an angle of about 40 degrees, his only help being tufts of thick grass growing in the cracks and the weather-beaten holes in the rock, and he quickly reached the top.

I felt rather taken down, as I had a reputation to uphold as a quick climber, and when I reached the top I expected to see him climbing down successfully, but the unfortunate quarryman was standing at the bottom of the quarry, his face bleeding badly.

Then Mr J. J. Neale shouted to me, and begged me not to climb down that way, because the quarryman had tumbled off the rock, and they had thought he had killed himself. There was a ridge about 20 feet from the top, and he had fallen on that ridge in a lucky way, and on to the sloping bottom of the quarry by the merest good luck; if he had overbalanced on to the other side of the quarry bottom, 200 feet down, he would have been flattened out and have broken every bone in his body.

I was very eager to try and get level with the quarryman, who had made me feel small, 


\section{My Climbing Adventures}

so therefore I replied to $\mathrm{Mr}$ Neale that I could climb it easily enough and in safety too. I climbed down the overhanging part until I came to where it dipped under; then I climbed out on to the vertical wall, which had the 200-feet drop, to hand- and foot-holds I had previously discovered, and just as I stood there a thought occurred to me that I would balance a piece of long grass or twig on my nose, and hang on to the vertical wall at the same time. I found a suitable piece near at hand, and was lucky in getting perfectly calm atmosphere; I balanced it on my nose for about twenty-five seconds. Then turning to the crowd, I explained that I was not only climbing the rock, but I was climbing it safely, and that any one might rush the climb, but they invariably came to a sad and untimely end. I finished the climb in safety.

The balancing of the twig or long grass made a very great impression on $\mathrm{Mr} \mathrm{J}$. J. Neale, and he talked about it for two or three years afterwards. The story was "How I got level with the quarryman," and gave a climbing lecture to a crowd of people while hanging on to a vertical wall.

$\mathrm{Mr}$ Thompson was highly satisfied, and presented me with a copy of the Climbers' Club Journal. in which he had written a long article, explaining the 56 


\section{Extraordinary Rock Climbs}

climb and showing a photograph of the Garth stone quarry, with the rock standing up in the middle.

The Walnut Tree “Matterhorn" Climb. By Mr J. J. Neale, J.P., of Penarth.

I HAVE been asked to write a short account of this climb :-

At the village of Walnut Tree, some seven miles from Cardiff, there is an old quarry. In the centre of it there has been left, for some reason, a mass of rock which, from its shape and no doubt through the difficulty of climbing it, has been called locally the Walnut Tree "Matterhorn." This has been a favourite place in recent times for good climbers to practise upon before going to Switzerland and elsewhere. It had never been (before our visit) known to have been climbed single-handed. I believe once or twice it had been negotiated by climbers roped together.

Mr S. Turner asked me if I would go with him and see him try it single-handed. I consented, and asked Mr Peter Thompson, one of the best climbers in the country, to accompany me. 


\section{My Climbing Adventures}

The Saturday afternoon had been wet, and for hand-work I thought it risky for Mr Turner to attempt, but he decided to try it. For a long time he made very little progress-solittle, in fact, that Mr Thompson and I considered he was not going to succeed. While we were watching him, two men, dressed like labourers, came to look. One of them was an Irishman, and he at once said he could climb it better than Mr Turner. He had evidently been drinking by his manner. $\mathrm{He}$ at once commenced the climb, and quickly passed Mr Turner and went towards the farther end, which was the difficult point, by which to descend. He completely left $\mathrm{Mr}$ Turner, and we lost sight of him.

I said to Mr Thompson, "I believe that Irishman is going to try to descend from the peak down the perpendicular side." He thought, with me, that he would scarcely be so foolhardy, but we both decided to walk round and see.

Just as we got there, we saw him attempting to descend, and knew that it was impossible, from his position, to do so safely. Just at that moment he fell, struck the cliff in his fall, and bounded out and fell on the rocky ground at the bottom. We ran up, expecting to find him killed, or at least badly injured, but he was neither. $\mathrm{He}$ was cut $5^{8}$ 


\section{Extraordinary Rock Climbs}

about the face and bleeding a little, but apparently the Providence which often protects foolhardy people had protected him.

In the meantime Turner had reached the top of the ridge, and asked where the Irishman was. We told him to go back, for as the Irishman had fallen, we thought it might unnerve Turner. He declined to do so. The Irishman looked up at Turner and shouted, "Sure I could climb up and down again another time before ye." In spite of the taunt, we again asked Turner not to attempt it, but he insisted on trying. Turner then carefully, and with the utmost coolness, commenced the descent. When he got to the most difficult part of the descent, he pulled a stem of a dead plant from a crevice in the cliff, and standing upon one leg he balanced the stem perfectly upright upon his nose, and at the same time called out to the Irishman, "Can you do that?" This latest feat astonished even the Irishman; he was speechless, tacitly admitted his defeat and went away. Turner then resumed his descent and reached the ground without the least mishap.

In explanation of the feat of balancing the stem on his nose, we afterwards found that $\mathrm{Mr}$ Turner was an expert at that sort of thing. I must say 


\section{My Climbing Adventures}

it looked like bravado, but it impressed the Irishman more than anything."

Shortly after this I read an article in the Palt Mall Magazine, illustrated by those famous English rock-climbers, the Brothers Abraham. Ker Knotts chimney and crack were supposed to be the hardest climbs in the English climbing district, so I took a special journey, with a copy of this valued magazine in my pocket, and not being able to get any climber to risk his neck with me, I took the hotel proprietor and the copy of the magazine, and climbed the Ker Knotts chimney alone in the rain.

After this it rained all day and night, keeping all the climbers indoors, so two or three of us did the barn-door traverse, that is, up the edge of a barn wall and across it into the barn door. By this time I found that I could not pass any piece of rock high enough for one to kill oneself on without looking for a possible route up it, and I climbed every wall, cliff, and even up to fix the weathercock in Trinity Church, Penarth.

My next amusing episode occurred when I climbed the Watch Tower, or Ilam Rock, Dovedale, Derbyshire. My friend Holmes was not the famous Sherlock Holmes, but he was a genius in detect- 


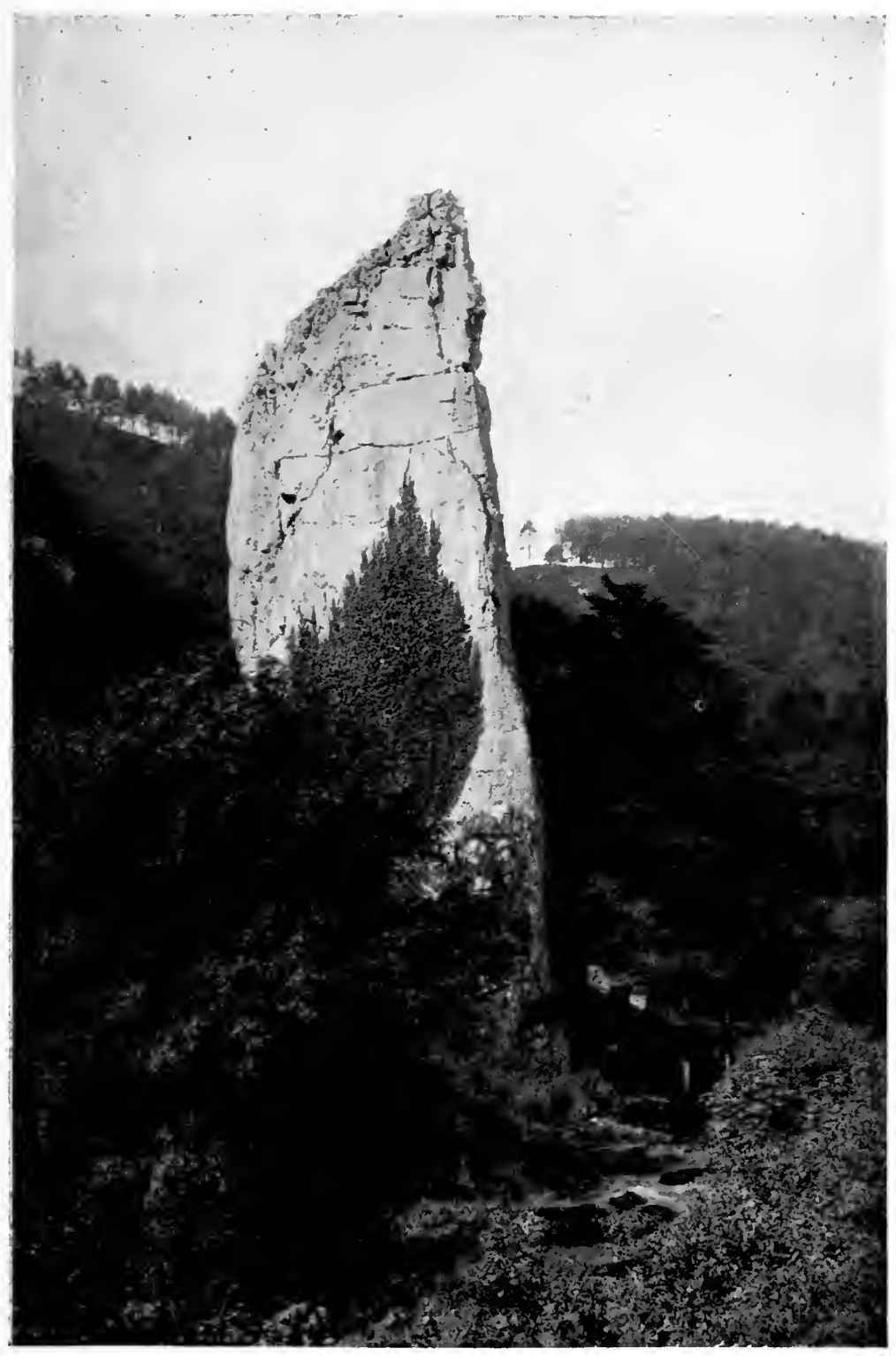

ILAM ROCK, DOVEDALE, DERBYSHIRE.

To face p. 6o, 



\section{Extraordinary Rock Climbs}

ing the way through holes and caves all through Derbyshire; and after his climb of Monte Rosa he detected a climb which he thought I alone was the man to unravel. I journeyed to Alsop-in-the-Dale, Station, near Buxton, Derbyshire, and by his assistance and that of the Rev. A. Wallaker of Buxton, we managed to get a rope over, but could not make it secure enough on the other side to be any use.

After this I climbed a little way up the rock, and it encouraged me, by letting a lump of limestone (of which it is composed) drop on my head, raising a big lump.

I came down, feeling rather seedy, and we adjourned to the hut at the foot of this rock to take what lunch the old man caretaker could give us. Dovedale is a pleasure place, and it was Bank Holiday, with plenty of trippers about, so while we were having lunch the old gentleman commenced to talk about this most attractive piece of rock, the Ilam Rock.

He said: "That rock is over 200 feet high, from the River Dove at its foot. It has no place for anybody to get hold of to climb it, and it is quite vertical and overhanging in some places. There have been hundreds of parties trying to climb it, but they have never succeeded, and never will. The top 


\section{My Climbing Adventures}

of that rock is the place where the birds of Dovedale fly when they want to die, and it is covered by the skeletons of birds." $\mathrm{He}$ continued: "There are some men trying to climb it again to-day, but they will hurt themselves, like many more before them." My companions interrupted the old gentleman by roaring with laughter, when I placed my hand on the big lump on my head.

We adjourned from lunch and I went at the climb with more determination than ever. I had previously not known it was such a difficult problem, or that many people had attempted it; but now I was sure, and Holmes also told me of some Alpine Club men who had given it up as impossible.

After carefully climbing the rock by the slowest and safest way possible, I got myself wedged into an overhanging chimney, the climax to the climb. As luck would have it, I was the exact fit to wedge myself into this crack, but it was such an awkward crack that it required all the strength I could exert to keep myself wedged tightly in and wriggle up in snail-like movements. The crack was only 40 feet long, but it took me about an hour to get to the top ; then I almost slipped off the rock as I crawled out at the top. I was absolutely winded as I sat on the top of the lowest side of the rock. 


\section{Extraordinary Rock Climbs}

The crowd down below gave me a great cheer, but the old man was in the crowd, and did not agree that his famous rock was climbed until I got to the other end, which was higher. The rock was about 2 feet wide at the very top, then it suddenly slanted out to about 8 feet thick, and the middle to the base of the rock was about 12 to 20 feet thick. It was blowing very hard, but I would not crawl on hands and knees, and it required very careful walking to get to the other end. When I did reach there I found it was overhanging. I stood up on the edge, and the trippers who had cameras took photographs of me and again cheered. This was the only time I climbed to the applause of the crowd. Carefully turning round I walked back over bones of birds and hawks as the old man had said, and after leaving a penny on the top under a stone and my name on some paper for the next climber, I began the descent. By this time a Sundayschool choir-party were singing hymns at the base underneath the overhanging crack. As I climbed down the crack I found it all I could do to prevent myself tumbling out. If I had done so, I don't think I would have killed myself, but the chap singing, "Abide with me" below would have had a shock. 


\section{My Climbing Adventures}

I consider the Ilam Rock climb more difficult than any Cumberland climb.

This climb was gazetted in all the papers in the north of England. It is a well-known piece of rock, and of the most extraordinary formation, so that it is known all over Derbyshire. That climb was six years ago, but nobody has made a second climb although there have been numerous attempts by well-equipped parties. Two of my friends were in that district last year, and paid a visit to this rock, and asked the old hut-keeper if any one had ever climbed the Ilam Rock. He said: "Nobody except Sam Turner has ever climbed to the top of yond rock."

\section{Ilam Rock Climb}

By Mr A. B. Holmes, Member of the Derbyshire Pennine Club.

I HAVE had several expeditions with $\mathrm{Mr}$ Samuel Turner, whom I consider one of the finest rockclimbers and mountaineers of the present day.

In Switzerland I was present both at the commencement and conclusion of his record climb of the Matterhorn, with guides Tangwald and Bergener. He made, in the opinion of local experts at 64 


\section{Extraordinary Rock Climbs}

Zermatt, a record ascent from the Hotel Monte Rosa to the summit of the Matterhorn. I met him on his return journey, when I found him in splendid condition.

After his ascent of the Matterhorn, I had the same guides for the ascent of Monte Rosa. Mr Turner promised to meet me near the Gorner Glacier on my return.

He kept his word, and whilst we were in conversation about the incidents of my journey, another party of two guides and a Dutchman came by, and the Dutchman asked $\mathrm{Mr}$ Turner to accompany their expedition. He was wholly unprepared, and had no climbing outfit with him. However, after I warned him of the dangerous condition of the ice ridge on the Dufour Spitze (the highest of the seven peaks of Monte Rosa), and the fact that the Dutchman was an inexperienced climber, he yet essayed to venture, and quickly borrowing one or two necessaries from myself, he proceeded on his climb of the second highest European peak.

I was delighted to welcome $\mathrm{Mr}$ Turner again, eighteen hours afterwards, at the hotel in splendid condition after his exciting experiences, he previously having climbed the Matterhorn three days before. 


\section{My Climbing Adventures}

I have also had experience, along with a ministerial friend, of the climbing powers of $\mathrm{Mr}$ Turner in Derbyshire.

On August Bank Holiday, in the year 1903, a party of three visited that charming retreat on the borders of Derbyshire and Staffordshire,-viz., Dovedale. I had mentioned to Mr Turner that the famous Ilam Rock had never been climbed, although on several occasions it had been attacked by expert and venturesome rock climbers.

The situation at once appealed to him, and as before mentioned a party of three determined to conquer this impregnable rock, if it was possible for man to do it.

The day was very windy, although fine, and Dovedale was looking at its best in the height of summer.

The Ilam Rock rises practically perpendicular from the edge of the stream, its inhospitable sides offering few footholds and little or no vegetation.

A rope was after some time got over the top, and $\mathrm{Mr}$ Turner commenced foot by foot on his perilous climb.

Crowds had in the meantime assembled in the valley below, and watched breathlessly the progress of $\mathrm{Mr}$ Turner. The onlookers were more than 


\section{Extraordinary Rock Climbs}

surprised to find that the expert climber was practically not using the rope; and how he kept progressing higher yet higher was a marvel to all.

A slight crack near the top gave him an opportunity for a brief rest, by clinging with both hands to the sides of the limestone, whilst he had only a slender and delicate foothold.

Inch by inch he gradually climbed, until, to the surprise of all, he appeared on the top, and immediately walked on the very narrow edge of the rock to the overhanging end, below which the River Dove flowed.

Thus for the first time in history this magnificent perpendicular rock was climbed, and the descent made in little under two hours-an achievement which has never since been accomplished though often attempted, owing to the loose character of the limestone formation and the shattered and worn crag, more especially the higher portions. I consider this one of Mr Turner's greatest climbs of its kind, which I predict will stand "a record" for a long time.

On again reaching terra firma and proceeding across the bridge to the Derbyshire side of the valley, the climber was cheered by a large holiday 


\section{My Climbing Adventures}

crowd, which had gathered and had witnessed the "daring exploit."

The Manchester Guardian, Chronicle and Evening News on the day after contained references to the incident, and it was also widely reported in the general press of the country.

These miniature-rock climbs may not interest the average Alpine climber, but there have sprung up all over England and Scotland rucksack ramblers and climbers' clubs, who climb anything worth climbing. These clubs, in some cases, have 500 and 600 members, and miniature-rock climbs are what they thrive on. A friend informed me of a club at Cambridge University, which not only does all possible miniature-rock climbs, but tackles walls, church-steeples, and every possible place climbable. If Darwin were alive now, he would find in these University students one more of his marvellous coincidences, similar to those coincidences in life upon which he built up the theory of evolution. He would, no doubt, reason that the climbing instinct in man and monkey alike proves that for some time after the supposed change from monkey to man, both monkey and man climbed; until man, becoming the intelligent 


\section{Extraordinary Rock Climbs}

being, left the forest, so that he would not have to constantly climb trees out of the way of serpents, lions, and other hungry wild beasts of the forest. As a natural consequence of man not using his tail, it gradually became shorter and shorter, and before he grew out of the habit of constantly sitting his tail wore off, and now he rides, bicycles, motors, sits on chairs and in the House of Lords and Commons so long pondering over Tariff Reform, that his tail has no chance to grow again. $\mathrm{He}$ would probably wind up his concluding remarks on this theory by stating that the climbing instinct in man is only a recurrence of the habit of his forefathers. I believe that the present-day climbers climb miniature-rock climbs that no monkey could climb, because of the simple reason that the monkey could not find places to bring his invaluable tail into play. These miniature-rock climbs are the very best practice one can get, if high mountains are to be climbed in safety; because it is the little bit of difficult rock that causes accidents or cheats the otherwise successful climber out of the final success of the climb. 


\section{CHAPTER IV}

SOUTH TO NORTH TRAVERSE OF AIGUILLE DES CHARMOZ PINNACLE, THE MOST DANGEROUS ROCK CLIMB IN SWITZERLAND - THE ATTEMPT ON AIGUILLE DU DRU-SNOWSTORM-TOUR OF MONT BLANC.

THE Aiguilles of the Mont Blanc group are 1 the most fitting for a rock climb of the first degree of danger and difficulty, and I think you will agree with me when you have read my description of the first traverse of the Aiguille des Charmoz pinnacles from south to north.

I invited $\mathrm{Mr}$ A. H. Binns of Sunderland to climb with me, because he was the record holder for the Matterhorn before I beat it. We journeyed to Chamonix in August (the best month for rock climbing) in rgor. We engaged Joseph Couttet and François Mugnier as guide and porter for a week's climbing in the mountains, staying at the Mountainrest. I wished to do the same as other climbers, who manage to climb a number of peaks in a short time by making the base of their operations at as high a mountain 

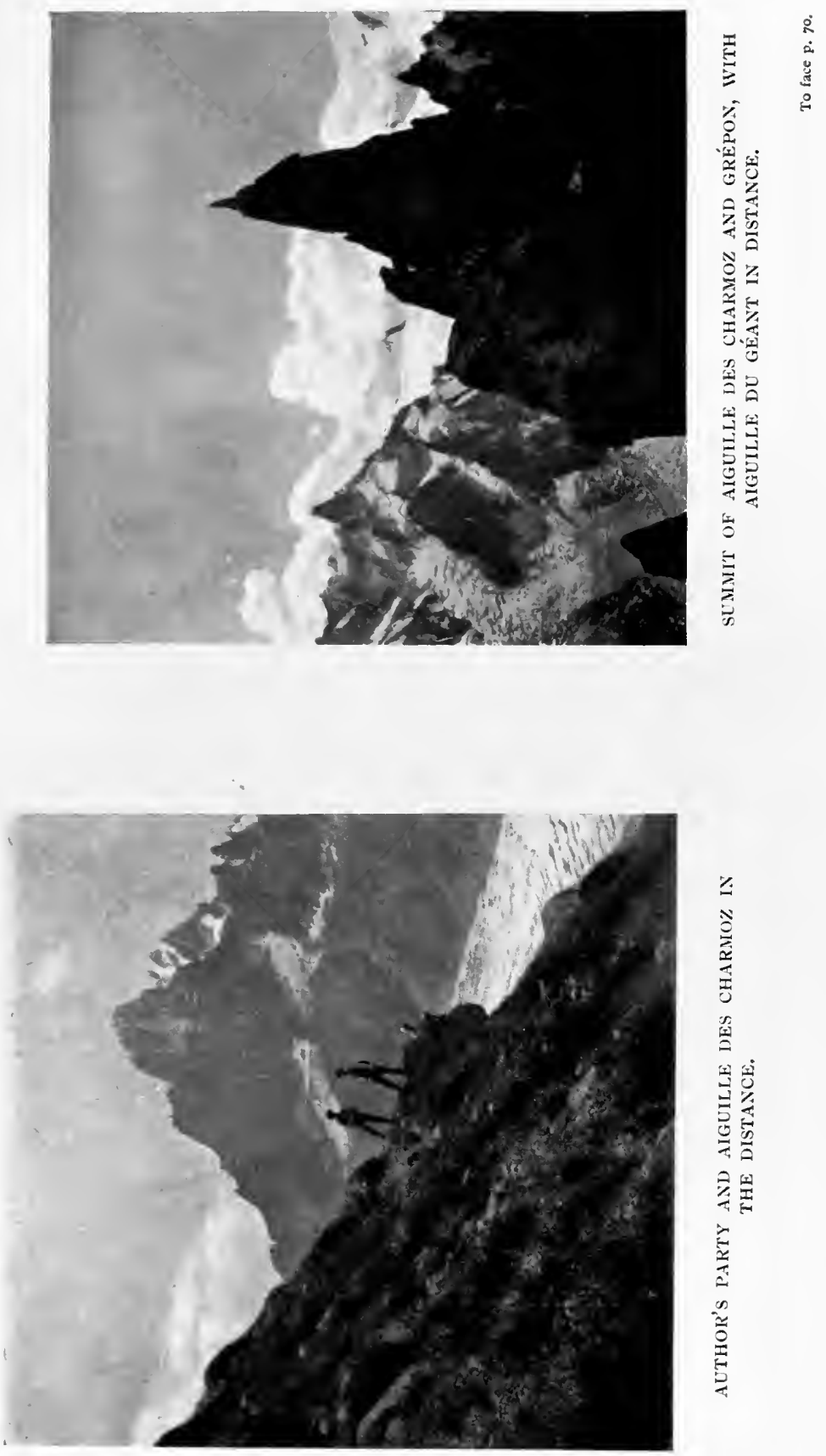

告 


\section{Dangerous Swiss Climbs}

châlet or hut as they can get. We intended returning to the Mountainrest after our first climb, and climbing other peaks from there. We started on a rainy day, trusting that the weather would clear up. These Aiguille-tipped peaks are at the end of the Mont Blanc group, overlooking the Mer-de-Glace, which polishes the rocks at their base 5000 feet below. The summit, I I, 293 feet above sea-level, seen from many points, seems to be a sharp needle of rock, but on close inspection is really a long serrated crest, or ridge, with many sharp towers poised on the ridge. There are ten important pinnacles, some terminating in actual spikes, like church-steeples, others having large blocks poised on the top, as though a strong gust of wind would blow them off. We intended to traverse these pinnacles-that is, to climb up one side and down the other side of each pinnacle. The usual climb is the highest pinnacle, the Aiguille des Charmoz, first ascended in 1880 by the late A. F. Mummery. The traverse from north to south was first accomplished in 1885 , but the south to north had hitherto been looked upon as unclimbable by fair means; and the climb, so far as I was able to discover, was never mentioned in any guide-book. This 


\section{My Climbing Adventures}

new climb was a special attraction to us. If you will look well at the panoramic view, it will enable you to follow our movements and gain a good idea of the exposed nature of the pinnacles.

We soon arrived at the Plan des Aiguilles, a lofty plateau which overlooks the valley of Chamonix (at the base of a whole regiment of Aiguilles), to rest for the night. The hut is quite up to the average of mountain huts, and is the one place to start for any peak that feeds the Nantillon Glacier.

After dinner the weather looked anything but promising, and as we stood in the doorway the light of the lamp reflected our shadows very large on the clouds which were beneath us. We decided to make a start at 2 A.M., but waited until three for the misty clouds to clear away. Our route was a very rough one, and we had to pick our way by the aid of a lantern. We soon rose above the clouds and welcomed the first sign of dawn, bringing peak after peak out of dark slumber to life and sparking brightness. You must picture the Nantillon Glacier crawling down between peaks about 300 feet higher than the Mer-de-Glace, at a height of about 9000 feet above sea-level. It forms a highway to the base of the Aiguille des 


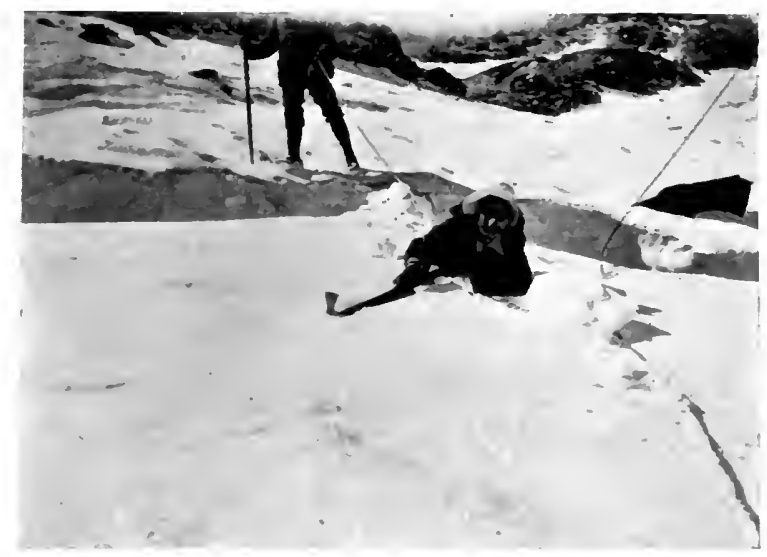

A. H. BINNS FAlLs into A CREVASSE.

(Author photographed him before pulling him out.)

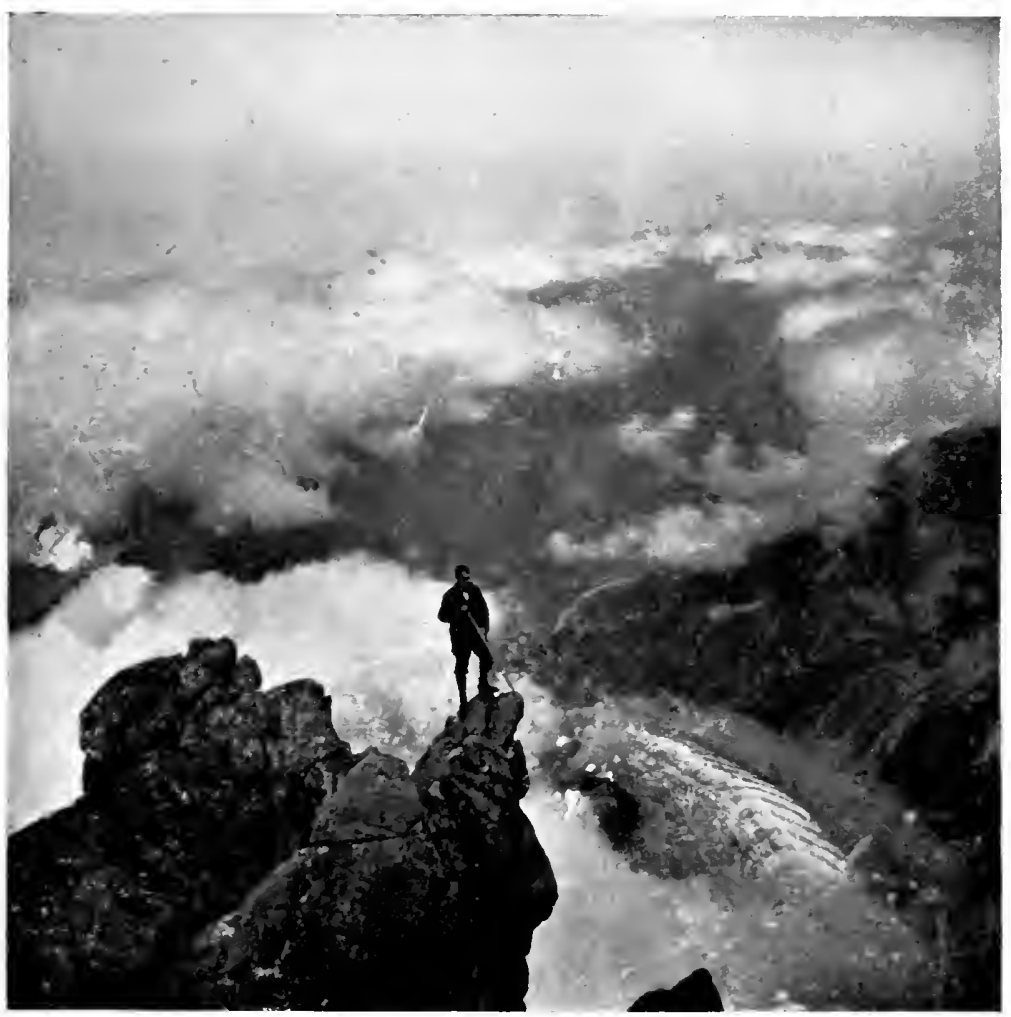

A. H. BINNS POSES FOR AUTHOR TO PHOTOGRAPH 5,0OO FEET ABOVE MER DE. GLACE, SEEN BELOW. 



\section{Dangerous Swiss Climbs}

Charmoz. Picking our way up the centre of the glacier; "we crossed quite a quantity of fresh-fallen snow and ice, which had apparently just plunged over a precipice 500 feet of a sheer drop. We turned by the ice fall to the right, and passed very close to a number of overhanging séracs, which seemed to be in doubt whether to tumble or not. The whole glacier centre does its best to smash itself into pieces, by trying to crawl down a small precipice ending in a terrific plunge on to the glacier below.

With very little step-cutting we were soon crossing the last crevasses, and came to a Bergschrund, where the glacier had not been fed by snow and ice from the rocks, and had left a crack between the rocks and ice on about an equal slope to the rocks. Luckily, we found a snow-bridge, which made it easy to gain the rocks, and then we were on the base of the actual peak, the Aiguille de Chamonix. Turning to the left, we worked up steep rocks for an hour : only one or two slabs gave us any trouble. Once my friend gripped a piece of rock which was loose, and it nearly came away with him; and so we reached the top of the secondary ridge which abuts against the final cliff of the mountain. 


\section{My Climbing Adventures}

The rocks here were particularly steep. We had to climb round sheer precipices, moving one at a time from one scanty ledge to another. On most mountains-even the Matterhorn-you rarely meet vertical precipices, but on the Aiguille des Charmoz and Grépon, they are absolutely vertical, with only cracks and ledges of the scantiest description to climb round or up.

For the benefit of the non-climber, I may explain that chimneys are aptly-named formations, which provide the only way up the needle-tipped peaks. They usually take the shape of fissures in the rock, varying from 3 to 20 feet in depth, and 3 to 4 feet in width. If a layer of bricks could be built on the outside of a mountain chimney, they would form the shape of an ordinary tall or factory chimney. The art of chimney-climbing is difficult, but there is no place on a rock climb where the expert is at home more, and where more wonderful acrobatic feats can be performed. A broad chimney is climbed with feet on one side and back on the other; but, if narrow enough, it is climbed by one leg and one arm on each side of the crack. The last of our chimney work led us up to a dome-shaped rock, which seemed to divide the two extreme peaks. 


\section{Dangerous Swiss Climbs}

This was one of the most interesting. It was possible to lie on the left side, with the left shoulder and half the back jammed against it, with the knees on the slanting rock.

Our movements were naturally very slow; but this only lasted a few minutes, and we came to the narrow ridge which overhangs the Mer-de-Glace, and separates the two peaks of the south end of the Charmoz.

You will notice that the whole of the ridge is called the Aiguille des Charmoz, but the peak of that name is the highest one of the whole ridge, and it stands almost alone. It is sometimes called the Grépon. This is a mistake, because the Grépon is the next peak further along the ridge, divided by a huge chasm, and is quite as difficult as the Charmoz peak itself, but not so difficult as the whole of the Charmoz pinnacles, including the Chamonix taken all in one climb.

We scrambled up on to the summit of the Charmoz at 8.45 A.M. ; but as only two of us could get on to it at once, $\mathrm{Mr}$ Binns and the porter climbed on to the next lower peak. I shouted for Binns to stand on the edge of an out-jutting pinnacle, little thinking it would nearly cost him his life. As he put his ice-axe on the most out-jutting 


\section{My Climbing Adventures}

part, in order to steady himself for the next step, the large stone toppled over, and he only just regained his balance. I took a snapshot of him from the summit before he stepped off this uncertain stand. The photo came out showing the depths of the Chamonix valley, and the river running down 9000 feet below; also the glacier, somewhat hidden from view by clouds beneath us. We joined our companions, and proceeded to the next pinnacle. This was a rock wall, 30 to 40 feet high, about 20 feet broad, with the right side overhanging the Mer-de-Glace 5000 feet below, the left side overlooking an abyss of about 2000 feet.

The only chance of climbing it was by a crack, which appeared to split it in two from its summit, but the entrance to this welcome crack was overlooking a drop of about 2000 feet. Once on the top of this, Mugnier climbed round the rock, his hand gripped the edge, and immediately afterwards vanished, and the porter followed, but got too far in the crack, and became handicapped by the rucksack on his back. I climbed it more on the outside like the guide, and Binns used the same tactics, and so a very ugly-looking climb was overcome.

The crack opened wider the further it went in, 76 


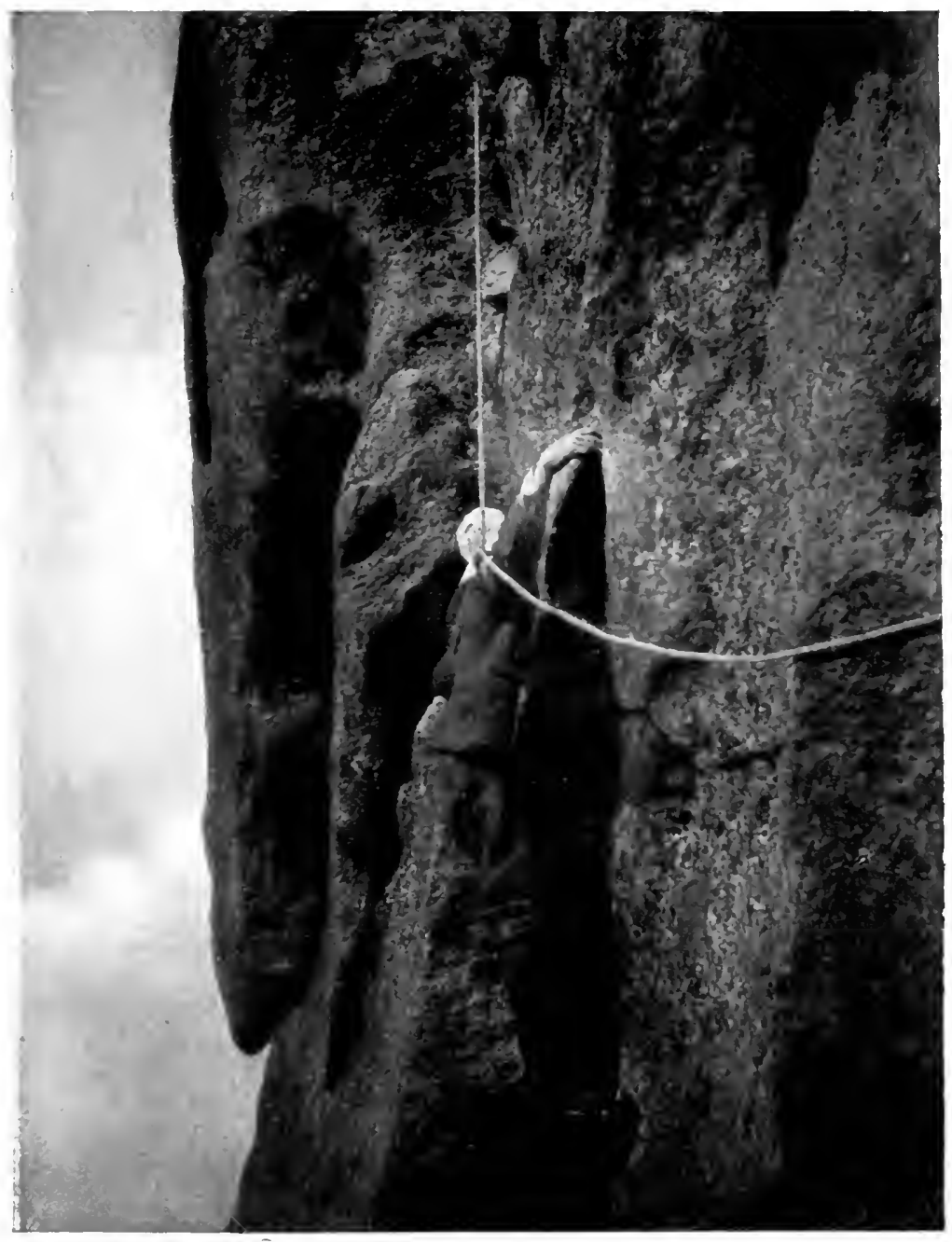

"IS IT POSSIHLE?"

(Author climbing round orerhanging precipices on the Aiguille des Charmoz.) 
- 


\section{Dangerous Swiss Climbs}

with sides of smooth weather-beaten granite, which accounted for the difficulty. We rested for a while on the ridge to admire the view.

We stood under a deep blue sky, almost cloudless; what few clouds there were only helped to intensify the beautiful scenery. We were standing on a mountain with the sharpest and most difficult of peaks or pinnacles that could possibly be worn on rock. These pinnacles are composed of crystalline granite, and this kind of rock is capable of being weather-worn and frost-split to a finer point than any other kind of rock; and these enemies of the mountain had done their work almost to perfection. I cannot remember all the struggles with complicated cracks, fissures, chimneys and precipices clearly enough to describe them; but we seemed to be constantly facing apparently impossible climbs, and no sooner had we finished feeling delight by our skill in conquering one obstacle than we were studying how to overcome another problem quite as difficult. I have chosen for description those climbs which made the most impression on me. These pinnacles are the most extreme contrast to Mont Blanc, which towered above us. In the distance, the Grandes Jorasses group made a specially beautiful photograph, 


\section{My Climbing Adventures}

aided by the clouds clustering round them. Very distant peaks were not visible, owing to clouds. It is a sheer drop of 5000 feet to the Mer-de-Glace, and it looks 10,000, because the rocks are void of snow. On the Charmoz itself two of us had lunch, sitting quietly on a 2 -feet by 6-feet summit, but the summits of other pinnacles were too small to allow more than one at a time, and only by careful work at that.

The next and sharpest pinnacle on the traverse is about 6 feet round at its base, with a top of about 18 inches square, and 16 feet from ridge to top and next to no hand-holes. (The hand-holes on Napes Needle, in Cumberland, one of the English needle-tipped miniature-rock climbs are like steps and stairs compared with this pinnacle.) By the aid of Mugnier I scaled the top of it; but it was not necessary for the whole party to follow. Time was going, so we hurried on, and came face to face with a perpendicular three-cornered slab, about 30 feet high. It took us ten minutes trying different ways to find out how to overcome this apparently impregnable obstacle. Mugnier tried to climb up by our help, but failed. I held the porter's hand while he looked round on the precipice; and we each did a bit of looking for 78 


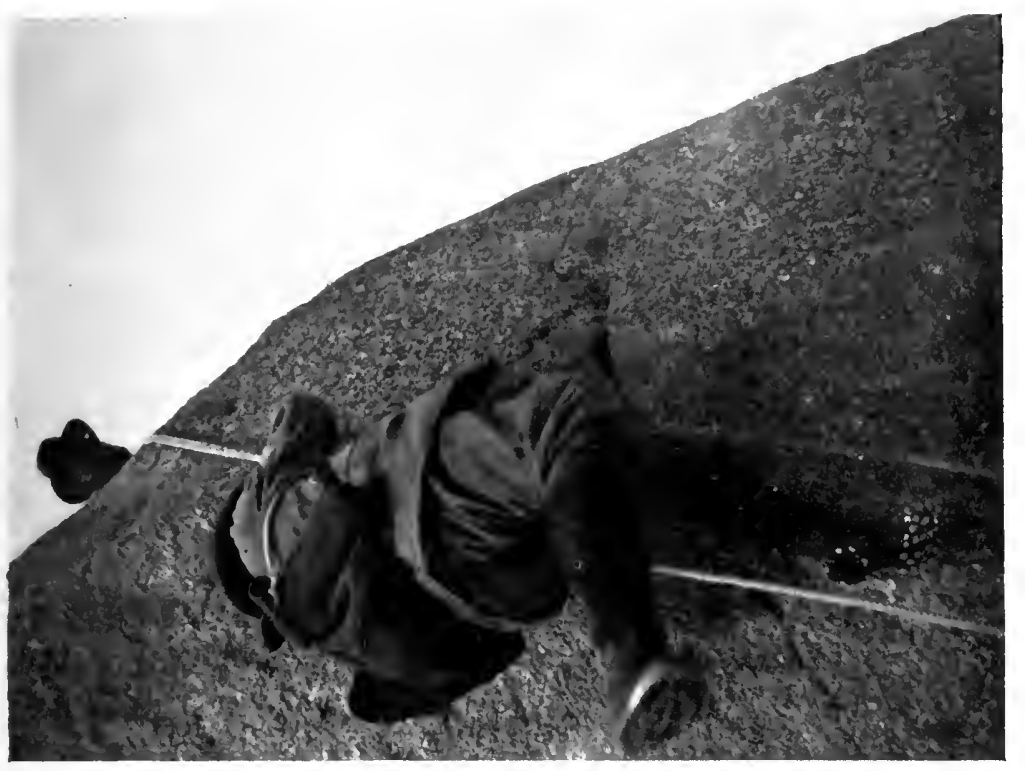

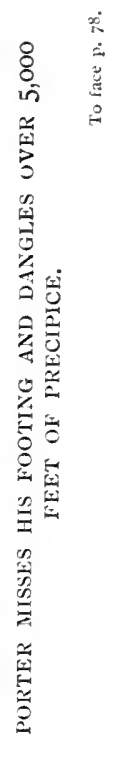

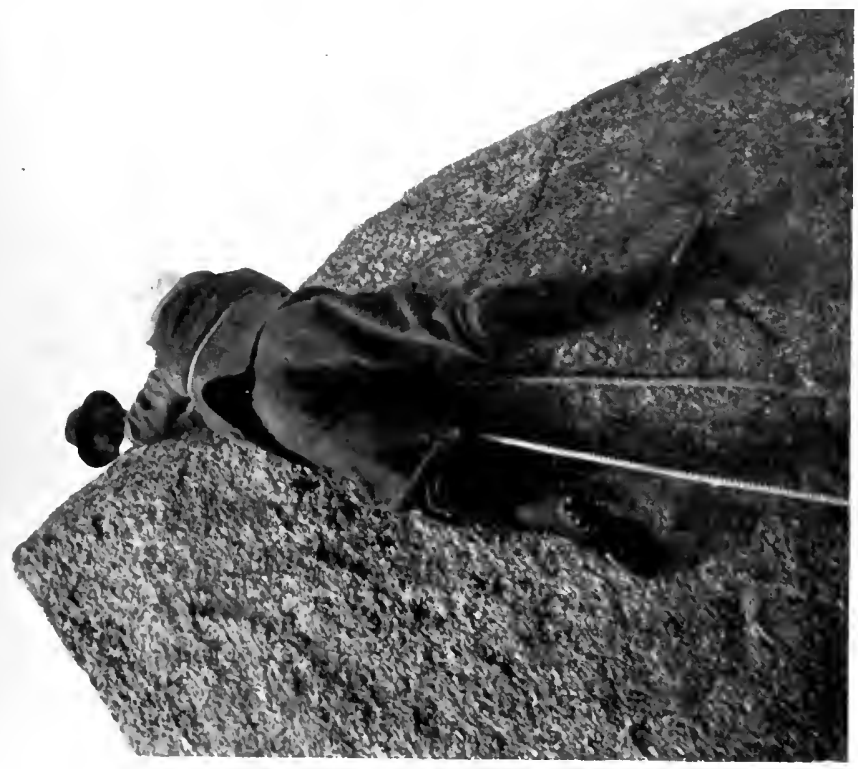

ह

2
$\vdots$
0
0

焉

넝

t.

萦量

ㄷ․

然

题

ए

资

突

5

苞 


\section{Dangerous Swiss Climbs}

cracks or possible grips. Then Mugnier, equal to the occasion, climbed along to the corner which was overhanging the Nantillon Glacier, and, after a pause, took more rope and vanished, still holding on to the corner. The hand disappeared, and the rope tightened for me to follow. When I got to the edge, and was able to look round the corner, I was surprised to see the face of the rock at an angle of about 80 degrees, on which a 2-inch foothole was the help across the precipice to the ridge 4 to 5 feet away. Striding round and bringing my body after, I had to pull against the corner with my right hand, press against the weatherbeaten rock with my hand and clothes, and placing my cheek on the rock as additional leverage, I had to transfer my right foot into the crack where my left foot was. Then I carefully steadied myself balanced in the foothole, and jumped over space to the ridge 4 to 5 feet away. (It may seem tame to describe, but it took about five of the most careful minutes of my life.) A tooth of rock on the ledge gave me something to grip; at the same time I had a flash view of the glacier below. The porter took the jump safely after a lot of slow, careful climbing, then my friend Binns' turn came. He treated the climb with respect enough, and 


\section{My Climbing Adventures}

took it all right, until he rested with his left leg on the crack. He paused quite a while, and then jumped without changing his legs, his right leg making him face the precipice too much for a good jump. The next few seconds were full of suspense; he missed landing on the ledge with his feet, but seemed to fall on the rock. His left hand had been pulled off by the weight of his falling body, and his right was going when we pulled him on to the ledge, doubled in two; if he had got 2 -feet start he would have broken the rope or pulled us with him, as we had the rope wound round the tooth of rock. We sat for a few minutes thinking "what might have been," but before the incident laid hold of us seriously we were scrambling along the narrow ridge, tackling another pinnacle about 25 to 30 feet high. We all three held the rope while the guide did some risky work to get round and up on to the top.

Three of us would have held him had he slipped; but for the second man to have followed would have been unsafe. He luckily found a coil of rope just below that pinnacle, left by some one who had come the opposite direction to the one we were going. This rope was placed over the 80 


\section{Dangerous Swiss Climbs}

pinnacle, and it gave additional moral support while climbing this rock, as there was only one crack half-way up for a foothold. The top was round like a dome, and gave us a lot of trouble at the most inconvenient moment. Most of these pinnacles could not be climbed with rucksacks on, and they were too steep to enable us to use our ice-axes, so we always lowered them off the pinnacles or pulled them up after us. This was the only breathing time we had during most of the six hours we were climbing on those pinnacles. The spare piece of rope which we found on the rocks came in very handy on this pinnacle. We placed it over the top, and lowered ourselves hand over hand, sticking to the two ends of the rope. After lowering myself for about Io feet it went over a sharp out-jutting ledge, and it was necessary to take a very wide grip to get past, then the feet dangled in mid-air until a footing could be groped for and found by the feet. I had found the rope rather shaky, so held it for the others until the porter nearly lowered himself on my head. After accepting the ice-axes lowered to me, I scrambled along a narrow ledge. We rounded another square pinnacle of rock, and came to the top of a broad chimney. At last we had finished the pinnacles. 


\section{My Climbing Adventures}

Neither of us had been on the Charmoz before, and that made it much more difficult, and gave us all the climbing we wanted, taking pieces out of our hands and legs, besides plenty of skin. The Charmoz peak itself was first climbed by the late A. F. Mummery in 1880 ; the traverse from north to south in 1885 , and again in 1887 by Wick's party, who made a slight variation; but the traverse from south to north was left to my party to accomplish. The climb by the route we took would be quite impossible in frosty weather. We found a slab of rock jutting out over the entrance to the chimney, and some thinner rope than the one we found was wound round this rock four times, and cut off near the knot, showing that the party had used it to pull themselves up with.

Before we started to climb this chimney we examined the rope we had found, but it proved to be too weather-beaten and weak to use on this climb, so we untied ourselves, and with the end tied round me I reached the bottom of the chimney before unroping. I stood on a broad ledge covered with snow, and helped the others to find the scanty footholes near the bottom, Mugnier coming down last. After throwing the middle of the rope over the rock and taking the loose ends, he lowered 

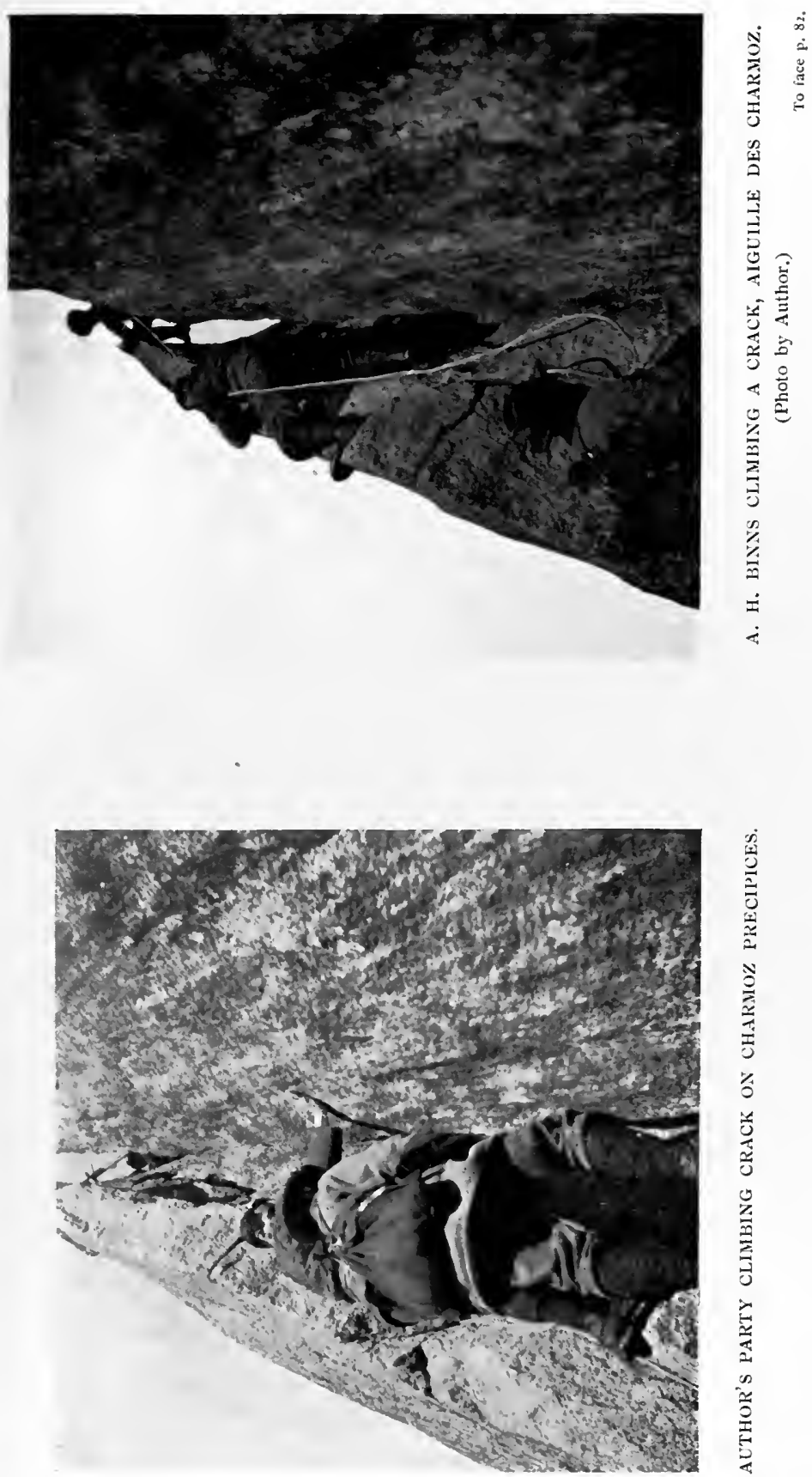

资 



\section{Dangerous Swiss Climbs}

himself hand over hand to the best part of the chimney, then he pulled the rope down by one end and let it drop to the bottom of the chimney. On another climb I found Mugnier's method of pulling the rope after him (after going down hand over hand sticking to two ends) very useful at a most critical time climbing down the precipices of Mount Cook, but this is related later. We had plenty of rock to climb down but nothing worth special record. The Nantillon Glacier was a dangerous hard blue near the rocks and more difficult than up the centre. A Mr Binns, my friend's namesake, had lost his life on this glacier some time previous, when it was in a similar condition, so we were very cautious for some time until we reached rocks again some distance down the glacier, where we had placed our rucksacks in the early morning. While we enjoyed lunch, we looked up at the overhanging ledges and huge precipices which we had used to enable us to conquer the mountain. These precipices will keep the novice from reaching the Aiguille de Charmoz ridge, and make even the best guides proud of being able to climb them.

We hurried down to the Mountainrest Hotel, 


\section{My Climbing Adventures}

and over dinner a party of climbers expressed themselves astonished at our having started for the pinnacles in such bad weather. At the time we started they had been weather-bound, and had not done any climbing for two or three weeks. A party consisting of two men and three guides made an attempt on the lower end, or Chamonix side of the Charmoz ridge the following day; and this time it was my turn to see climbers through the telescope. I called my friend Binns' attention to the way one of the climbers was swinging on the rope and making desperate attempts to regain his footing on the rock, finally to be hauled up on to the ridge by his two guides. The second climber did very little better, and caused us some amusement.

The sight quietened a tourist who, the previous night at dinner, had said he did not see why he should not be able to engage guides at eight or nine francs a day to help him to place his feet on "peaks that had never been trod." Until he saw those men dangling over precipices he said he had no idea of the work that was necessary successfully to accomplish a first-rate peak. He evidently had the idea, like many people, that it is just a walk up a gradual slope to the summit, and they cannot 


\section{Dangerous Swiss Climbs}

see anything in it. But this is not the case, and if it was, real climbers would not see anything in it either.

ATTEMPT ON THE AIGUILLE DU MIDI AND TOUR OF MONT BLANC

My next journey was to climb the Aiguille du Midi (returning to the hut Refugio Torino on the Italian side of the Col du Géant) and climb the Aiguille du Géant. We started early after a day's rest, and picked our way over the slopes of the Aiguille des Charmoz up the side of the Mer-deGlace by the aid of the lantern and on to the middle of the Glacier du Géant. From here the weather looked doubtful, and we had about three hours picking our way through all kinds of séracs and crevasses, and rested for lunch near the top of the glacier. We made for the Italian side of the Aiguille du Midi, and climbed some little way up its base, when we were enveloped in a snowstorm, causing us to hurry off the peak and make for the hut as best we could. We had a monotonous journey over snow-covered crevasses, and we seemed to take it in turns to tumble into 


\section{My Climbing Adventures}

them; but it did nothing more than keep us awake. In the warm mist that had taken the place of the snowstorm we arrived at the Refugio Torino, where we spent the night, hoping to climb the Aiguille du Géant from there if it cleared up the next day. The weather, however, became hopeless, and it was impossible to get back to Chamonix over the Glacier du Géant. We decided to make the tour of Mont Blanc up the Valley Alle Blanche and over the Col du Mont Tondu. We passed the Italian army encamped in the valley, and the band playing music which echoed in the Alps. Later on a regiment was at target practice; and they kept a crowd of English tourists and climbers, including Mrs and Mr Inglis Clark of Scotland, waiting at the top of the pass out of the danger-line. They were quite a mile: away from the line of fire, and they concluded that any nearer would be dangerous, although the regiment were shooting across Lake Combal and the path was the opposite side. We rested one night at the base of the Col du Mont Tondu, and climbed that pass and a peak near it and then down the glacier. Half-way down, Binns fell into a crevasse up to the waist, and I took a snapshot of him. Then I moved away about ${ }_{86}^{5}$ yards to be close to 


\section{Dangerous Swiss Climbs}

the guide, in order to pull on the rope together. When we pulled Binns out of the crevasse the snow gave way up to quite close to our feet; and revealed that I had taken his photograph while standing on a snow-bridge which covered a crevasse broad and deep enough to swallow a dozen men.

Hurrying down the glacier and back to $\mathrm{St}$ Gervais, we took train back to Chamonix, after being five days away.

After we ascended Col des Grands Montets, bad weather brought my holiday to a close; and since that holiday, with the exception of a few days' English rock-climbing, my holidays have been taken up with climbing in New Zealand, South America, and Siberia, which the following chapters of my book will describe.

While I was climbing in Switzerland I looked upon it as strenuous work, but since my experiences in other parts of the world, I have altered my opinion of the climbing in Switzerland. The plentiful supply of well-equipped mountain huts : well-known routes up most of the mountains, and luxurious hotels, ten to twelve hours from most of the summits; certified guides and porters, and many other advantages, turn Swiss Alpine climbing 


\section{My Climbing Adventures}

(if taken in suitable weather) into comparatively easy work, compared with the drawbacks and difficulties of unexplored or little-known mountains. The climbing is so fascinating and interesting in Switzerland that I never knew what it was to be tired, and I look forward in the future, when I stop wandering round the world, to returning to the European Alps, with all their associations, adventures, legends, and mysterious fatalities, which have made thousands of tourists look upon those same precipices and glaciers with awe and dread. 
BOOK I I 

, 


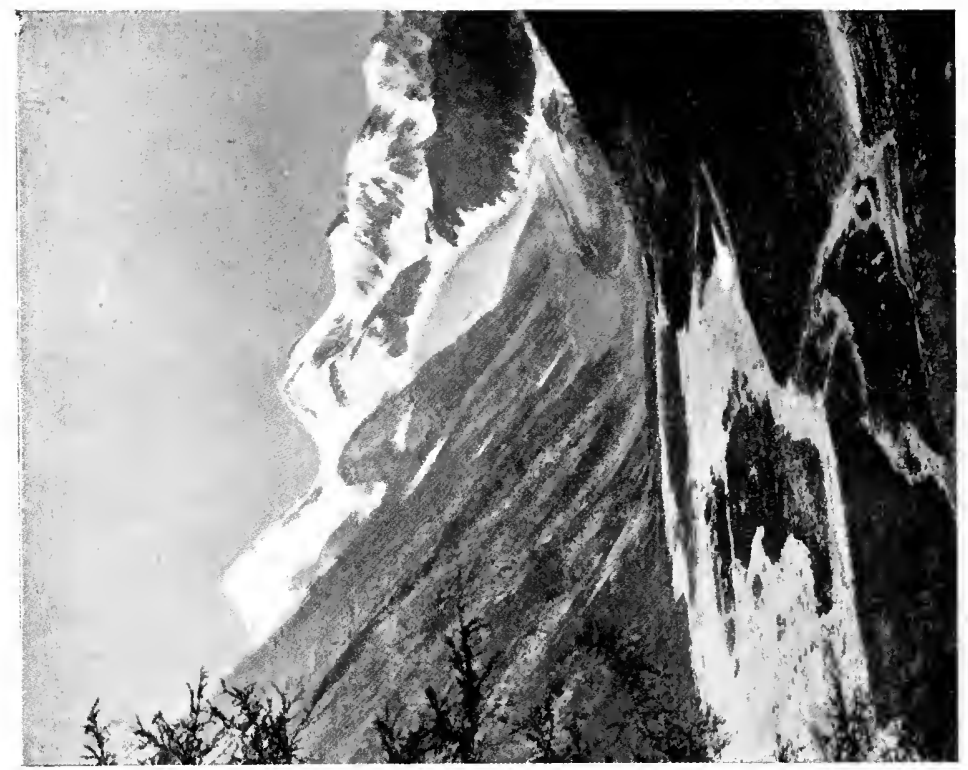

罂

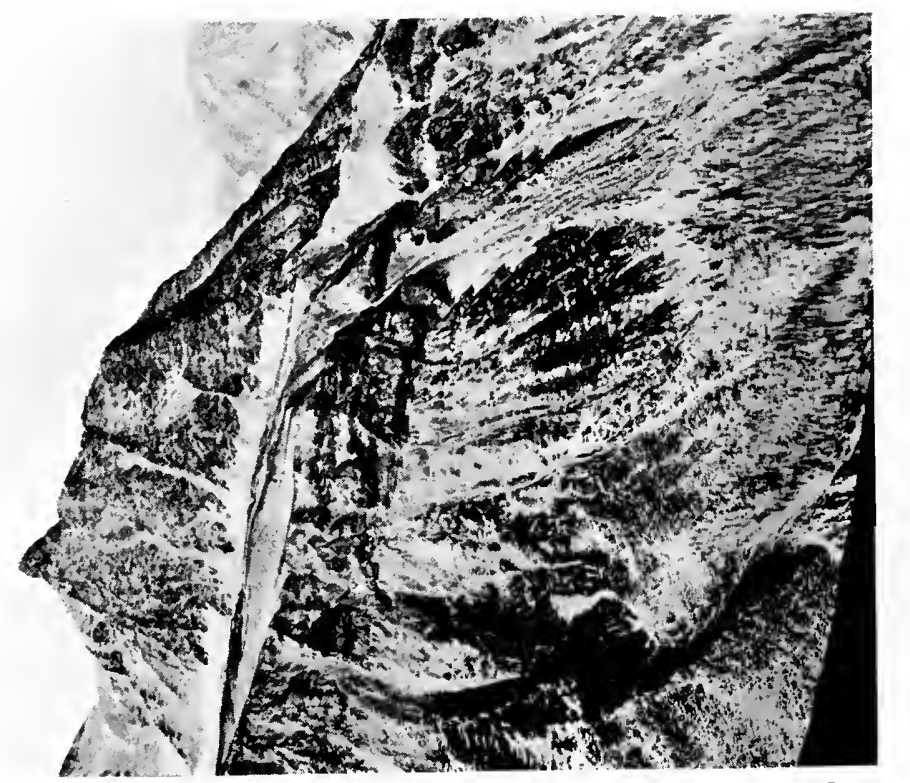

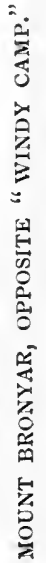




\section{CHAPTER V}

TRAVEL AND EXPLORATION IN SIBERIAN MOUNTAINS IN WINTER-MOUNTAIN-CLIMBING AND EXPLORATION

A $\mathrm{S}$ an introduction to my Siberian expedition, I A take the account that appeared in the Daily Mail, London, shortly after my return, as follows :-

\section{An Englishman's Climb}

Remarkable Feat in the Altai Mountains

A remarkable mountaineering feat has been accomplished by an Englishman, Mr Samuel Turner, F.R.G.S., of London, who has just returned from an attempt to climb Belukha, in the Altai Mountains, Siberia. The Altai Mountains stretch from Tomsk, the capital of Siberia, to the Chinese border, South-West Siberia. They are very low at Tomsk, but after Biysk they are fairly high. To reach the highest, one leaves the Great Siberian Railway at the Obi Station and travels through Barnaul and Biysk to Katunda, 640 miles direct south of the Obi Station. From the great difficulty of reaching there, it is not surprising to find that no European has tried to explore these mountains, and there is no literature on the subject in English, save a short translation of about twenty lines from a paper read before the Imperial Russian Geographical Society. Professor Sapozhnikoff of the Tomsk University, with four companions, climbed 13,300 feet 


\section{My Climbing Adventures}

from the south side of Belukha, during the summer of 1900 , and then it was estimated that the mountain was 14,800 feet high. Mr Turner intended to confirm Professor Sapozhnikoff's measurements.

It was in the late winter, and though the Russian authorities were helpful, they declared any ascent was impossible; but $\mathrm{Mr}$ Turner engaged hunters and crossed the steppes in intensely cold weather, riding on sledges for three days and two nights, beyond the last small village, there being snowdrifts everywhere. Katunda was thus reached, and the journey was continued on horseback past the settlements of friendly Kalmucks, who had never seen an Englishman; and through a dense forest to the Akkem Valley.

It was first of all necessary to examine Belukha. Accordingly $\mathrm{Mr}$ Turner climbed one mountain, I7,800 feet, and did so alone, for the hunter he took with him and $\mathrm{Mr}$ P. Cattley, a young Irishman, would not take the risk, and stopped at the lower altitude. The following day $\mathrm{Mr}$ Turner climbed another mountain, and then commenced to scale the object of his visit. The party moved off at eleven o'clock, and after they had gone over a very difficult moraine for two hours, it commenced to snow, with the result that it frightened the hunters, and they left $\mathrm{Mr}$ Turner alone on the mountain, on the distinct understanding that they would be up at his tent by four o'clock next morning. It was a lonely afternoon and night, but the next morning, the hunters not being visible, Mr Turner started off at 5 A.M. The snow had stopped, and in four hours he reached the base of the actual peaks of Belukha. There are two peaks and a saddle between them, but he could only gain those ridges by a very difficult way. 


\section{Winter Climbing in Siberia}

It had also begun to snow again, but he decided to push on.

At the top of the second ridge he measured 13,800 feet, and left his name in Russian and English under a large stone, and then continued until he came to an ice slope descending from the summit. Owing to the hardness of the ice it took half an hour to cut one step, and as thirty were necessary, the climber was compelled to pause and remodel his plans. He tried to go down the south side of the mountain, but the fresh-fallen snow on the ice slope slipped with him for about 60 feet, and he was glad to get back to the ridge again. Then a north wind sprang up, with all its bitterness, obliging him to beat a hasty retreat to his tent. Soon afterwards Mr Turner felt ill; he attributed it to having poisoned himself by drinking soup out of a tin, and to a diet of snow-water with black bread and dry rusks, and tinned articles. His hands and face were swollen and it was hopeless to go on. Mr Turner had intended going to find some thermometers which Professor Sapozhnikoff had placed on the south side of the mountain. In addition to this slight poisoning, he had sustained severe inflammation of the eyes through the intensely cold winds. The expedition had come to an abrupt close. Mr Turner adds: "The view I shall never forget. Our third camp was on the side of a lake that had apparently frozen to the very bottom, as we dug down in the ice to about 6 feet and came to earth; this was about 12 feet from the edge of the lake. The mountains all round stood out like huge sentinels, but were scarcely as bold as the most massive group of the Alps."

Daily Mail, Ist June 1903.

In my last book, Travel, Exploration and F 


\section{My Climbing Adventures}

Climbing in Siberia, I gave an account of Siberian climbing, but omitted quite a lot of details, which I will include in this chapter. There are many things which will bear repeating, because Siberia's remote mountains are not known to the general reader, and I am quite certain that English-speaking people will welcome information about them. Since my last book, several well-known explorers, including a famous big-game hunter, have written to me for full details of the hunting to be got in the Siberian Altai Mountains.

The animals are similar to those that lived in Europe in the time of Julius Cæsar, and one must go to the Altai Mountains ready to protect himself against wolves, bears, wild dogs and other animals ; also from escaped exiles, even more dangerous than the animals.

I had not the remotest idea that there were mountains in Siberia, and should probably never have given the matter any consideration, but for the remarks of a fellow-director of a commercial company I was interested in. $\mathrm{He}$ said he was glad there were no mountains in Siberia where I might kill myself. The next day I was in London, and the Librarian of the Royal Geographical Society kindly gave me quite a lot of information 94 


\section{Winter Climbing in Siberia}

about the different systems of the Siberian and Central Asian Mountains; but the only information he could give me about the Altai Mountains was a few lines translated from Professor Sapozhnikoff's lecture before the Imperial Russian Geographical Society. These few lines described a mountain called Belukha, supposed to be r 3,300 feet, which had been measured by Professor Sapozhnikoff as I 4,800 feet, and said that it was situated in $86^{\circ} 30^{\prime}$ east longitude.

I was going to Siberia on business, and if I cared to go to the most remote part where it was possible for me to do business, Biysk, I would be about 400 miles from Mount Belukha.

My journey was in the winter, and it could not be altered for the sake of mountain climbing; so rather than give up the idea of climbing amongst unknown mountains, I decided to take all risks. My outfit was limited to what I could carry with me on the boat to Riga and on the trains in Russia and Siberia, relying upon getting a large tent and further equipment in Siberia. In this I was disappointed. The Russian Customs officer at Riga passed my baggage when I explained my intention to climb in the Siberian Altai; but he was not aware that my pockets were full of cartridges and 


\section{My Climbing Adventures}

that I had a revolver in my hip-pocket. My next step towards Belukha was after my business had been completed in Western Siberia. I journeyed to the Obi Station and completed arrangements to take Mr P. Cattley (a son of a Fellow of the Royal Geographical Society, living at this station) with me as interpreter and companion. We journeyed to Tomsk, and had lunch with Professor Sapozhnikoff at the Tomsk University. $\mathrm{He}$ was sure that I could not get near Belukha in winter, and said we would require snow-shoes to get to the Saptam Mountains, 40 miles away from Belukha. He said he had gone in the summer when the boat took them as far as Biysk; and there being good level roads and no snow, the rest of the distance was covered by droshky. I left him and saw the Governor of Tomsk the following day, to try and get the use of the post-sledges. The letter from the Minister of Ways and Communications, which I had received while in St Petersburg, helped me a little, but the Governor of Tomsk wanted to know too much about our plans. Mr P. Cattley endeavoured to satisfy him, without interpreting the conversation to me, and nearly caused trouble.

The Governor wanted to know how we intended to get back if severe weather or a spring thaw 96 


\section{Winter Climbing in Siberia}

locked us in the mountains. I informed him that I could not afford to run any risk of being locked up in the mountains, and would cut the climbing short if I found the winter drawing to a close.

The winter changes to summer in fourteen days but it takes a long time for the swamps (made by the snow melting) to sink into the hard frozen ground. The Governor was a strange mixture of suspicion and kindness. My opinion of him changed many times during that interview, which lasted about an hour. The sharp manner in which he demanded my passport before opening our conversation, and his kind-hearted information-imparting manner during the conversation, were two widely different characteristics. His intense geniality at the close of our interview, and the promise of the letter which he never sent me, were even more difficult characteristics for me to understand.

The warm-hearted, familiar manner of the educated Russian and the strict official exacting mannerism both in the same individual, make one misunderstand the real man. His warm-hearted manner contrasts very strangely with his official manner, and, owing to his affectionate ways being often taken advantage of by those under his orders, 


\section{My Climbing Adventures}

he is compelled, in order to reassert his authority, to be more severe than would otherwise be necessary. This characteristic, which I had come into contact with in the Governor of Tomsk, accounts for a good deal of the attempts to overthrow power and authority in Russia.

In justice to the Governor of Tomsk, I must mention that I visited him just after a student rising caused by anarchists.

We journeyed back to the Obi Station and made preparations for the journey through the Altai of about 1600 miles to Belukha and back, calling at Barnaul and Biysk on my way. I had travelled on the town sledges at the rate of 12 to 14 miles an hour, and calculated our journey at this rate of speed; but when I saw the kind of sledge that goes through the steppes of Siberia, I began to think of 8 miles an hour; but we did not get more than 5 or 6 miles an hour for the first stage. The difficult and trying nature of sledge-travelling on the Siberian steppes might be the reason why Russians rarely travel in the winter, excepting the ordinary moujik with the goods-carrying sledges, which go at a very slow pace. Traffic sledges break the snow on the roads up into holes, sometimes 3 feet deep and 6 to 8 feet across. There 98 


\section{Winter Climbing in Siberia}

are no round stones to stop the snow from shifting, like those one sees in the streets of Moscow, St Petersburg and other Russian towns.

Our baggage was placed on the bottom of the sledge, hay on the top, and we sat on the top of the hay; one sledge instead of two was the quickest way to travel. The horses were whipped and shouted at by the moujik to get up full speed when we neared these holes, and the sledge took the hole with a leap to the other side, coming down with a bang. We were raised a foot or so along with our luggage, which sometimes settled down before us, and sometimes we settled down to the bottom of the sledge before the luggage. The shuba and overcoat would become crumbled up into the middle of our backs, and remained like that sometimes for 5 or 6 miles; while our legs up to the hips became frozen, despite the valenkis (felt top-boots) we wore. We grew indifferent to back- and bone-ache, and very often were fagged and frozen to sleep. If we had been of the lean kind and thinly-clad, it is possible we might have broken a bone or two, but we were both meaty and well clothed, with a thickness of about 6 inches of clothing around us, so we only bruised ourselves by being banged on to 


\section{My Climbing Adventures}

the corner pieces of baggage. What a contrast winter and summer is in the Altai! In winter, 20 to 30 degrees below zero (Réaumur), io to 50 feet of snow, snowdrifts everywhere-in some cases nearly burying the black-and-white-striped verstpost that showed us our track from one village to another; hungry wolves, bears, and ferocious escaped exiles. The River Obi and its tributaries, almost obliterated by snowdrifts on ice, Io to I 5 feet thick. Horses covered with frost, dead horses lying on the roadside at intervals along the route, and the road and sledge as described. In summer-Droshky, over fairly smooth roads, the most brilliantly-coloured flowers in the world, all kinds of bird-life, boats and pleasure-steamers up the River Obi for 400 miles; plenty of fishing, shooting and life everywhere.

My only excuse for going in the winter was business; the journey should not be taken in winter. It is too dangerous and trying, and the Siberian steppes are one vast, snowy desert, with less than a desert's landmarks to guide you, once off the post-road. If you stick to the postroad, it is possible to get all over Siberia, both extreme north and south, guided by the black-striped Russian verst-post, unless it gets buried in the snow. 


\section{Winter Climbing in Siberia}

The Royal Horticultural Society of London, in translating a chapter on the Altai flora for me, made the statement that the Altai is the natural home of most of our English hothouse plants. The abundance of the Altai flora is conveyed by the fact that 50,000 tons of honey and 150 tons of bees'-wax have been exported from the Altai in one year. It is the flower-garden of the world in the summer. There are many geographical and atmospheric reasons for this, and, although the temperature falls lower than in any other part of Siberia or the world (72 degrees below zero, Réaumur), the thick covering of snow protects the roots, and the spring thaw gives the necessary water to make the flowers shoot up suddenly in the early summer. While the Arctic is the coldest place in the world in winter, it is one of the hottest places in the world in the summer.

Intense cold winds had blown the snow off some part of the town of Barnaul and again at Biysk, where we made a pause. I nearly lost my interpreter at Biysk; the Russians made him frightened by showing him crevasses in one of the glaciers from one of Professor Sapozhnikoff's photographs. It upset him so much that he said he was wanted at home, and did not intend to be killed on any dirty 


\section{My Climbing Adventnres}

mountain, so he said I had better go by myself. It took four hours for me to persuade him to go on with me; and as a last attempt I asked him what the Russians would think, and I told him that the Irish race was noted particularly for pluck, and that if he did show the white feather he would be the first Irishman I ever knew to exhibit such a trait of character. I also promised that he had no need to climb, but that I would leave him at the last village and secure him a man to go hunting with if he would wait for me. We carried on this discourse in his bedroom, where he sent for me to tell me his verdict and the reason he was in bed at ten o'clock in the morning, when he agreed to start at 5 A.m. The final straw that broke the back of his opposition was the fact that I had made ready and definitely told him I was going alone, and he would be responsible if I got lost, owing to not knowing enough of the Russian language, and that I could not get another interpreter. He knew I was going alone; the people of the house made him aware that I had prepared; so, finally, on condition I left him at the last village to go hunting, he agreed to come, but he was the manager of me and my movements until I turned my back on the mountains, coming home. The opposition shown me by IO2 


\section{Winter Climbing in Siberia}

everybody up to Biysk and at Biysk made me more determined than ever. Just before starting we bought a rifle in Birsk, because one of the leading merchants, $\mathrm{Mr}$ Sitchef, said we were not well enough armed only having one gun and two revolvers; and that we should encounter bears and wolves on our way.

Mr Sitchef lent me a large shuba, which was a very valuable part of my kit. The journey of I 80 miles from Obi to Barnaul, and the 100 miles from Barnaul to Biysk, had been extremely cold; and the wind caused by the movement of the sledge makes io degrees below zero almost unbearable.

The first stage from Biysk was 16 miles to Krasnobaisk. On the way we had our first view of the Altai Mountains, and reached the village at half-past seven in the evening. It was dark, and the room in which we were to have dinner had about ten peasants sleeping on the floor. It was anything but a comfortable position to be in, when one remembers the reckless disregard of life in Siberia. I entertained the peasants by balancing a paper cup on my nose and burning it while balancing, etc., which they appreciated very much, and it placed me in a friendly position with them. 103 


\section{My Climbing Adventures}

I found that an entertainment or two like this very often made the suspicious characters forget that I might be what they considered a wealthy man. It is possible that many of these men were quite harmless; but there are many escaped exiles about, and exiles who are connected with the different villages (not the educated political exiles, but criminals). There are men amongst them who would not think twice, if they knew you had a fortune of, say, $\swarrow_{2}$ or $\swarrow_{3}-19$ to 28 roubles-in your pocket, of trying to extract it by the Siberian strangulation method, or any other deadly way. It was this knowledge which made me feel that it would pay me to humour them into feeling I was not one of the aristocrats whom they hate so much.

We started at half-past eight for Altaiskoë, our next stage, 34 miles, and although the weather was clear when we started, it became very misty and this intensified the dark. We passed the leader of a pack of wolves which I wanted to shoot, but he cleared off before we could get back to where we had passed him. We overtook a horse running on before us on the road, which, no doubt, the wolves had chased. We heard the howling of the pack (which evidently that wolf was preceding) as they 104 


\section{Winter Climbing in Siberia}

crossed our track, but we did not see any more of them. We experienced considerable difficulty in keeping to the track. The only guide our moujik had was the sledge ruts, but these were often obliterated by drift-snow. We soon stuck in a snowdrift and realised that we were lost.

We looked about for some hut or farm to enquire our way, and after a while approached a hut, but the inhabitants were too afraid to answer the door. We knew they were inside, but they evidently thought us thieves, or worse. We went back to our sledge and helped to pull the horses out of the snow-heap, only to see them flounder into another; but after many attempts to liberate them, we seemed to strike hard ground without deep snow. While the horses were resting we heard voices and running water very distinctly, but although we shouted and fired off our revolvers to make them hear, we got no answer. It was rather strange to hear running water when there could not be any unfrozen water for 1000 to 1500 miles.

We tried many ways to gain our track again, and, after being stuck in snowdrifts two or three times, crossing and recrossing where we calculated our track was, we managed to gain it again, or what we thought was the track. The rest of the I05 


\section{My Climbing Adventures}

distance was done with nothing to complain about, except the intense cold. It was growing serious with us when we found the track.

It was two o'clock in the morning when we reached Altaiskoë. The people in charge of the post-stations were always very obliging, and were the very essence of servility; and at this uncomfortable hour they hurried about, after rubbing their eyes, and soon had the samovar lighted and hot water ready to make tea. The kindness and consideration of these poor "post-hut keeping peasants" is something to win the heart of the traveller. The warmness of their welcome is only exceeded by the heat of their houses, which at times becomes stifling. We arranged with a Russian trader, before he left Biysk for Mongolia, to have some bear-hunting with him at Altaiskoë. 'This station is at the junction of the road leading to Belukha in the extreme south of Siberia and Mongolia, and our friend had gone on that evening, because we had promised to be there a day earlier. Perhaps it is as well we had no bear-hunt. There are two sides to hunting the Siberian bear: he has a very keen smell, and runs as fast as an express engine, therefore it is just possible he may scent

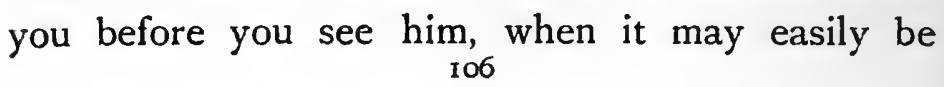




\section{Winter Climbing in Siberia}

turned into a man hunt. We left Altaiskoë after a few hours' rest, but had some difficulty in getting a moujik to take us on to Barancha, 27 miles. The moujik assured us that he could make more money bringing in wood from the forest. This sledgeowner was the only aggressive moujik we had come in contact with, and he wanted all his own way with us; but he drove at a good pace and this made up for his aggressiveness. On this stage we went over the first pass, the Shimelovskaya, 3500 feet above sea-level. The distance from Altaiskoë to the base of the pass is 2 miles, while the summit is 2 miles further. We were now in the mountainous country. Descending, we came to a butter-making creamery. The quality of the butter they produced was very good; the sanitary conditions of this particular dairy were poor and very different to the up-to-date creameries near the Siberian railway line. We reached Barancha about noon; the village policeman was a study in modesty, judging by his manner-he informed us that he knew we were coming. The next stage, to Tavourack, was a short one, only 14 miles. The owner of the sledge wanted double fare, because he said the road was in bad condition. We had to pay or walk it, as he was the only sledge-owner in this village. 107 


\section{My Climbing Adventnres}

We reached Tavourack at 5 P.M. Our next stage was Chorni-Anni, a distance of 24 miles, with an ascent of 6 miles up the valley; from the summit of this pass the River Chagran takes its source.

The sledge was constantly turning on to its side, and sometimes would run 200 to 300 yards before it could be righted. The ground in this particular valley was very muddy, and as it dragged along it filled my interpreter's shuba brimful of mud, much to his disgust. The poor moujik was disgusted with his language, and when we reached ChorniAnni Station, just before going into the post-house, I had to act the peacemaker. I never saw a man in a more intense rage than the moujik, but on entering the post-station he crossed himself before his favourite saint picture, and became both subdued and respectful and his simple obliging self again. We started on our next stage to Melia, Io miles beyond Chorni-Anni, in a droshky. Two miles on our way we passed the first Kalmuck settlement and a party of Kalmucks on their way to ChorniAnni, which is the central market in this part of the Altai, where the Siberian and Kalmuck exchange commodities. The scenery which we passed through was most beautiful. The valleys 


\section{Winter Climbing in Siberia}

are level, and the mountains rise abruptly from the level and protect the lowlands from winds. We photographed a Kalmuck shrine near this settlement.

The rites appear to consist in lighting a fire and walking round it with lighted faggots in their hands, offering prayers; a sort of Shamanism or, perhaps, it might more correctly be called Zoroastrianism.

We arrived at Ouskam at seven o'clock. Most of the villagers had gone after a pack of wolves that had, very inconsiderately, eaten two horses the previous night. We experienced some difficulty in procuring a sledge and team to take us further. We started the next stage of 40 miles to Abbi at eight o'clock in the evening.

The first part of the journey was through very fine scenery and over level ground. Some of the valleys were about 20 miles across. The rest of this stage escaped my notice; it was my turn to sleep. When I awoke, the temperature was 7 degrees below freezing-point. We were very glad to reach Abbi. We had travelled for thirty-two and a half hours with three halts of an hour each from Tavourack to Abbi, a total distance of 76 miles, 20 miles of which was over mountain passes and very slow going. 


\section{My Climbing Adventures}

A peasant who had just arrived from Koksa, 40 miles further on, offered to take us for three roubles $64 \frac{1}{2}$ miles, which we accepted, and we arranged to start at six o'clock in the morning, although it was four o'clock when we arrived. The first to miles was level road, then we turned to the left from the River Koksa, and began the ascent of the Korgomskië Mountain-pass, 5000 feet above the level of the sea. At one place the track ran for a distance of 200 yards along the edge of a precipice overhanging the River Koksa.

Descending from the pass, we travelled across a rich picturesque valley, the mountains around clad with pines, firs and birches, but there was a scarcity of trees in the valleys.

Bears and game of all kinds are plentiful in this neighbourhood. We passed some Kalmucks on horseback, armed with very primitive guns. We asked them what they were going to shoot, to which they piously replied: "Whatever God may send us." We had to take to the river presently, as the snow became too deep for the horses. In many places we drove through water, trusting that the ice was strong enough underneath. The climax came when we reached the River Abbi, a tributary of the Koksa, where the river flows between steep 


\section{Winter Climbing in Siberia}

mountain slopes. Here the ice was so broken up that we had to take it in turns to go in front of the sledge and test it before we ventured. Judging by the speed of the water, as seen in holes in the ice, the current of the Koksa is very swift.

At this part the river is about 20 feet deep and beautifully clear. We left the River Koksa and took a road to the left. In the afternoon we were informed that Mount Belukha could be seen, but we did not see it. We left Koksa, in the afternoon for Ouemon, a distance of 16 miles, travelling mostly downhill and over very rough ground, and reached the village in the evening. There was a doctor stopping at the post-stationthe only one within a radius of 100 miles; there is very little sickness in this Siberian mountainous region.

We had a letter of introduction to a Mr Oshlikoff, a wealthy merchant. We had to cross the river to his house. He gave us a friendly greeting, but was very serious in his persuasions not to attempt to go into the mountains during the Siberian winter.

This was about the twentieth man who was certain we would never come back again. My interpreter was impressed by this man's talk, but 


\section{My Climbing Adventures}

I argued that as nobody had been there in the winter, we could not tell if it was possible or not, and that the sooner some one settled the question the better. We had difficulty in getting rusks, and bread was out of the question-there was a great scarcity of all bread-stuff.

The ispring is three or four weeks earlier in this part than in the settlement of Novo-Nicolaëvsk on the Siberian railway. The previous year the ice had thawed before the $25^{\text {th }}$ of March. The winter begins in October-December being the coldest month.

We left Ouemon at mid-day and drove up the mountain slope to the Katunda saddle, which I measured to be 4850 feet above the level of the sea. We had a fine view of Katunda to the right, with the Saptam Mountain to the left and the KatunskiëBelki range in the distance. We descended to the flat valley of Katunda, 3000 feet below, the mountains forming a circle round it.

We reached Katunda late in the afternoon, having completed the journey from Biysk in three days and three nights. During the journey we had changed horses nine times, making eleven stages, of which the shortest was 8 miles, the longest 40 miles. 


\section{Winter Climbing in Siberia}

We were aided by the frozen rivers, which freeze to the bottom during some parts of the winter. The Katun, which is the principal tributary of the Obi, is a fast-flowing river, which takes its source in the southern portion of the Belukha Glacier. It follows a semicircular course, passing the valley north of the Katunskië-Belki. The numerous tributaries from the same range, which flow north for a distance of from 40 to 50 miles, are indebted for their tortuous course to the peculiar shape of the mountains. The River Katun, for instance, has an unbroken fall of 3700 feet in 200 miles, and some of its tributaries into the river from the mountains have a gradient of 2000 to 4000 feet in a similar distance.

We found the two hunters recommended by Professor Sapozhnikoff. One would not go because it was winter, and the other wanted double pay. This was the only man in the village who had been part of the way before, so I was glad to secure him at any price, and we took another Siberian whom he recommended. While the hunters were making preparations on the following day, we arranged for the post-house keeper to provide us with horses, and accompany us to the Saptam, the mountain that Professor Sapozhnikoff had mentioned. We 


\section{My Climbing Adventures}

had decided to have some ski practice on the slopes of the mountain, so took skis with us.

We crossed a flat valley through 18 inches of snow and gained the foot of the mountain in two hours. We had some good shooting and came across the skeleton of a bear. As already mentioned, the Altai is as rich in animals to-day as Europe was 2000 years ago, at the time of Julius Cæsar. Besides bears, there are gluttons, lynxes, foxes, badgers, klonkas, squirrels, sables, ermine, otters, hares, and a large variety of game birds. The chief attraction, however, are the ibex, and the real Ovis Ammon, both having exceptionally. large horns.

Besides the ordinary dangers of Alpine climbing, there are the dangers of intense cold and the warm reception one may get from some of these animals. We had some good ski practice on the slopes of the mountain where the snow was deep; and on more than one occasion descended into a basin-like dip, headforemost in the snow. After a few tumbles I became fairly proficient-except at times when one leg would insist upon going in the wrong direction, compelling me to sit down in the most inconvenient places. When we gained the summit of the Saptam Mountain, 9,750 feet, we were in a 


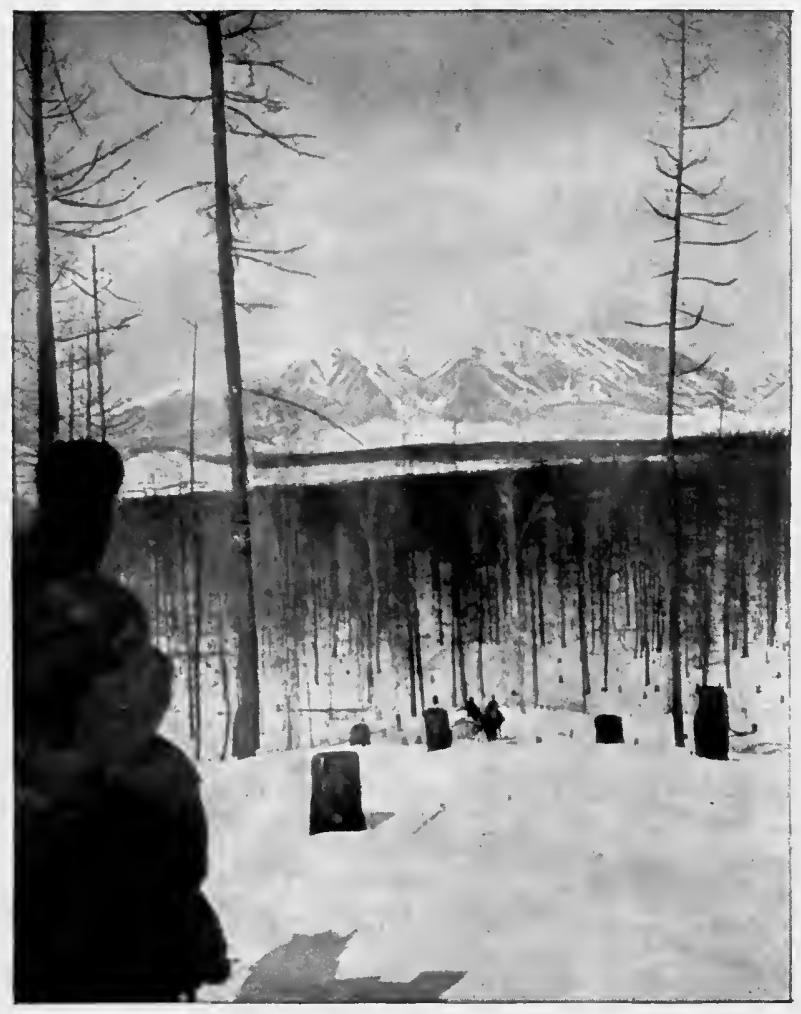

SAPTAM MOUNTAIN, NEAR KATUNDA.

Tu face p. 114 . 



\section{Winter Climbing in Siberia}

splendid position to see the Katunskië-Belki mountain range. I enjoyed six hours very interesting and difficult climbing on the Saptam pinnacles or adjacent mountains, which was rendered the more difficult from the fact that, thinking only of ski practice, I had left my nailed boots behind. The most difficult bit was the third pinnacle, where the rocks of the summit were split in two, and it was necessary to climb about 30 feet down a wall and then fall forward, gripping the rocks across the ravine about 4 feet wide and 80 feet deep. One of the highest peaks looked as though it had been split in two, forming a wall of rock for about 400 feet and as smooth as glass.

The rock of these summits was very soft-a kind of shale-and easily broken with the fingers. On the north side the slopes were all of loose rock, and being covered with snow, afforded very insecure footing.

The second summit was 10,000 feet in height, the third 10,050 feet, the fourth 10,020 feet, the fifth and sixth 10,000 feet each. I named the third, fourth and fifth peaks Faith, Hope and Charity, in the order as I came to them.

I was informed by the priest, who had lived in the village of Katunda for the past thirty years, 


\section{My Climbing Adventures}

that no one had ever climbed those pinnacles, although hunters had frequently ascended the Saptam Mountain hunting game. When I returned to the Saptam summit the moon was out, and it was with difficulty I found the hunter with my horses, my friend having gone back to Katunda four hours earlier.

The descent was very difficult and even dangerous on horseback, because with sunset the slopes had commenced to freeze, and the mountain is steep enough to ride down under the most favourable circumstances. We slipped and tumbled about merrily before we reached the valley. The moon is more brilliant in Siberia than in any other part of the world I have been in. The valley was lit up as clear as daytime. We arrived at Katunda Posthouse about midnight.

The journey was a splendid one, and I saw enough snow-capped high virgin peaks from the Saptam summit to keep the members of all the Climbers and Alpine Clubs in Europe climbing for the next few years. The climber must be able to shoot and ski who wishes to reach the summits of these mountains, because the bear might come on to him almost as quickly as the avalanche, and the ski is necessary to cross deep soft snow. 


\section{CHAPTER VI}

MORE MOUNTAIN DISCOVERY-CLIMBING AND EXPLORATION

ATUNDA is situated in $86^{\circ} 10^{\prime}$ east longi1 tude, and Belukha is $86^{\circ} 30^{\prime}$ east of Greenwich. From information I had received from Professor Sapozhnikoff I learned that Belukha, which was believed to be the highest mountain in Siberia, somewhat resembles Mont Blanc, in that it consists largely (on the south side) of a gradual snow slope and glacier. I had made enquiries about the most suitable route, and had learned that the southern approach is about three times longer than that from the north. The passes round the longest way were choked with very deep snow and therefore inaccessible to horses; we could not get dogs to draw sledges; therefore we had to abandon the idea of going to the south side of Belukha. We took skis with us, with the intention of proceeding on foot if the snow stopped the horses.

We made our first halt, after leaving the village of Katunda, at the house of a peasant recommended 


\section{My Climbing Adventures}

by Professor Sapozhnikoff as a suitable guide; but he refused to accompany us, as he considered the journey too dangerous.

Half an hour's ride after our first halt brought us to the River Katun, which we crossed, although the ice was breaking up. Arriving at the other side we entered a dense, trackless forest, through which we groped our way in complete darkness; it was very clever the way the leading horse found its way through it. Our rate of travelling was not more than 3 miles an hour. We had intended following the course of the river, but this was impossible as the ice was breaking. A second forest was entered and left behind us, and then we entered a mountain-pass which led us up to a height of 6100 feet. A Kalmuck followed closely behind. He seemed to treat the mountain-pass with great respect; and a tree on the summit, with pieces of all colours of ribbon tied to its branches, gave tokens of thankfulness on the Kalmucks' part for their safe arrival. After a brief rest we made a rapid descent, accompanied by a snowstorm, into the Akkem valley. The road down a steep zigzag for 2 or 3 miles ended in a sudden dip to the right into the Akkem valley, which at this particular place is quite flat-the Akkem valley itself is very narrow-the I 8 


\section{Siberian Discovery and Exploration}

slopes of mountains with the River Akkem running between. We pitched our tent earlier than we had intended, but this was owing to the heavy snowstorm. We had the company of a solitary Kalmuck bark hut. The owner scraped away the snow, his children brought some dry sticks from the hut, and he lit us a fire, while we unpacked the luggage, putting the guns and everything we wished to keep dry in his hut. I realised for the first time the folly of not bringing a large tent. Our tent was 6 feet 6 inches long and 3 feet high, weighing 12 pounds. When my interpreter and myself were inside it was a case of "when father turns we all turn." Any sudden movement might have brought the tent down, because the ground was frozen so very hard that we could not drive the tent-pegs in.

The Akkem valley, where we camped, is 4325 feet above sea-level, and the last Kalmuck bark hut was pitched there before reaching the mountain of the Katunskië-Belki. The Kalmuck informed us that nobody thought of going over the slopes of the mountains leading up the valley, because the horses would slip on the ice down into the River Akkem and would be killed with the rider.

We found the steep forest slopes frozen for 20 I 19 


\section{My Climbing Adventures}

miles. Before we had travelled half the distance we had been through all the antics and positions possible on horseback on the ice-glazed slopes. There was no track and the horses had to pick their way over fallen trees; we saw several herds of big game in the distance. Descending a slope and crossing the River Akkem at an altitude of 5650 feet, we obtained our first good view of the KatunskiëBelki. We dragged our horses up the opposite bank. After rounding the slopes of a mountain we emerged out of the forest to the left, and eventually reached the banks of the River Yarlow, a tributary of the Akkem. We selected a suitable elevated spot at the base of a mountain, and in close proximity to a forest, where we thought we would be protected from the wind and find wood, on which everything depended, as only two could sleep inside the tent at a time, and two of us would have to sleep before a fire in the open. It was either this or turning back, and I had come too far for that. On Professor Sapozhnikoff's map, which is the only one of this district, there is a River Yarlow. We found where the river evidently flowed in the summer, but it was quite dry ; and, judging by the stones forming the bed, it is only a mountain stream. There was no frozen water in any part of it; showing that the 


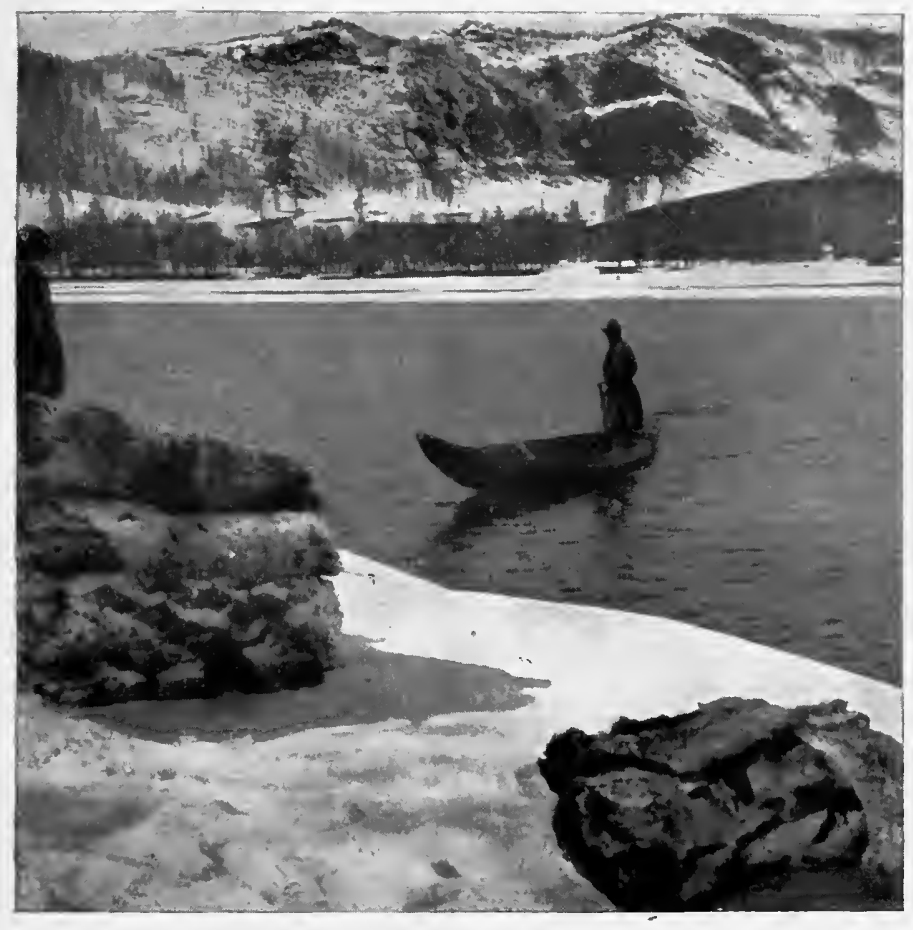

WE CROSS THE RIVER AKKEM IN CANOE. 



\section{Siberian Discovery and Exploration}

mountain tops and snow on the slopes had frozen first. This stream takes its course in the east of the Katunskië-Belki range, fed by a glacier, which I saw evidences of, but which remains to be discovered.

We had been on the road two days since leaving Katunda ; fourteen hours of this had been spent in all kinds of acrobatic feats on horseback on the slopes of mountains and through forests. It was on the second evening we encamped at 5.30 P.M., 8150 feet above sea-level. Snow commenced to fall at eight o'clock and the temperature in the open was only 34 degrees below freezing-point, Fahr. We could see Mount Belukha rising before us in a direct line 8 miles away, and we were in the circle of the Katunskië-Belki range.

Opposite our camp was a bank, covered to a great depth with snow, evidently a lateral moraine of the Belukha Glacier. It must be a very old moraine, as small trees, fir and pine, are growing on it. These trees were much younger than the forest trees around. The glacier had receded 4 miles at least, leaving a lake in between this old moraine and the present glacier. Everywhere was ice and snow and perfect stillness ; a more wild, desolate and rugged spot could not be imagined. I pitched the tent while the huntsmen went in search of wood. I 


\section{My Climbing Adventures}

joined them after fixing the tent, and we found, owing to the extraordinary dryness, that we could break very thick branches quite easily : this is owing to the very dry Siberian air. The wood burnt very freely, the kettle was boiled and soup prepared from two ryabchiks, which had fallen to our guns on the way. We also roasted half a sheep. After our first dinner, within sight of the long-looked-forward-to Belukha, I felt quite satisfied with myself and the surroundings, and reconciled to the complete loneliness and silence. One thing I noticed very quickly was the continual shifting of the direction of the wind. No sooner did we move round the fire to prevent the smoke of the fire blowing in our faces than the wind followed us round. It shifted so often, filling our eyes full of smoke, that I christened the spot "Windy Camp." We were near the junction of three valleys, and no doubt the next party who reaches this spot will know it by the Nestle's milk tins, Army and Navy ration and soup tins, and the general clearance of the trees.

After making plans for the morrow, we decided to retire to rest. Just as I was on the point of falling asleep a hurricane sprang up, which threatened to tear up the tent. We were up at five o'clock next morning, and I spent the first day exploring 


\section{Siberian Discovery and Exploration}

the Belukha Glacier and looking for a way up Belukha.

I made experiments to see how much the glacier was moving, and decided later on that it moves about as slowly as it is possible for a glacier to move. The ice was most exceptionally hard and compact ; I soon discovered it was impossible for the nails in my boots to make any impression on it. Although I stamped my feet I was unable to make the nails stick to enable me to walk up the slightest incline. We discovered a large number of boulders which had been scratched and grooved on the side nearest the glaciers. These were situated about 2 miles from the glacier itself, and showed how far it had receded.

Some of the grooves on boulders of which 1 took a photograph were half an inch broad and a quarter of an inch deep.

There were no marks of the progress of the glacier on the other side of the stones. The mountains on both sides are composed of granite, and are entirely without vegetation above the level of the glaciers. Huge heaps of rock had been split off these mountains and had fallen on the glacier. The only crystallised granite mountain was Belukha, yet thousands of enormous boulders were scattered on 


\section{My Climbing Adventures}

the edge of the glacier 6 miles from that mountain. Judging from the character of the glacier and the boulders, I should say that the mountain was at one time 4000 to 5000 feet higher than its present height, 14,800 feet. Most of these mountains appear to have been split in half quite recently by some powerful upheaval of the earth. One proof of this was the extreme softness of the rock, which had tumbled from the peaks and had sharp edges which did not show the slightest wear by ordinary denudation. Some of these rocks were so soft that I could break them by letting them fall 3 feet.

The Katunskië-Belki group forms a circle, the principal peaks of which have an average height of 14,000 feet. In the centre of this circle there are three mountain ridges, branching from north and south, which at a distance have the appearance of enormous fins. A mountain climber soon learns that even the mountains crumble; and some mountains which look solid rock from the distance are nothing better than a huge pile of loose rock and stones. Instead of looking for an avalanche of a few hundred tons of stone coming down the mountain, one might expect to see avalanches more like half a mountain fall in these Siberian 


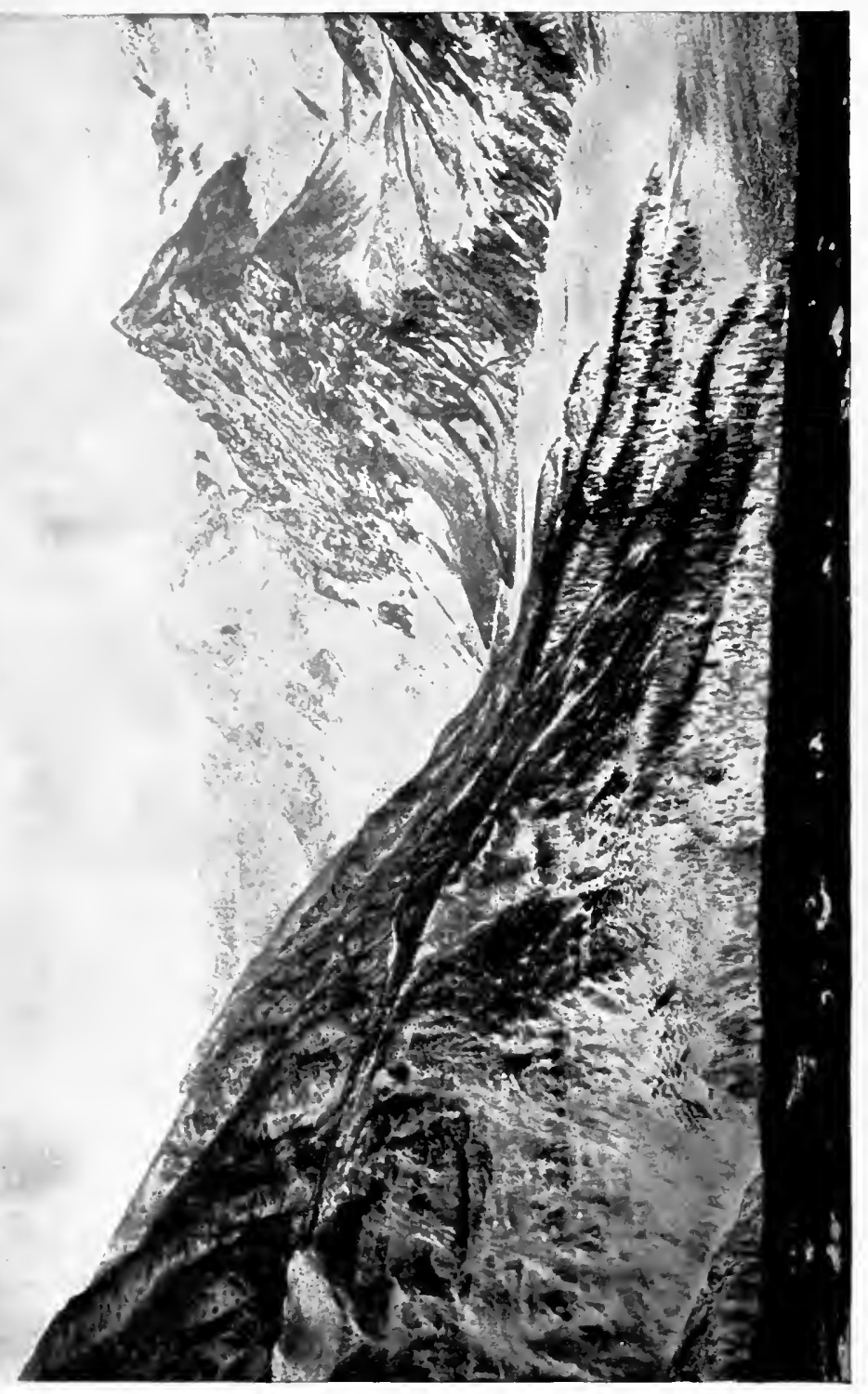

 



\section{Siberian Discovery and Exploration}

Alps. The moraine is composed of two ridges of boulders and stones, 200 to 250 feet higher than the glacier itself, and there appears to be more moraine than glacier. I have never seen so large a moraine, although I have stumbled over moraines in the Andes, New Zealand Alps and Swiss Alps; it is about 5 miles long from the top of the moraine.

I was attracted by a high pass, which seemed to give me a chance of getting a good look at Belukha's precipices. The north side of Belukha is a sheer precipice. When I reached the top of the pass I was astonished to see in the distance across the glacier two high glaciers and a very high mountain, much higher than Belukha: so I decided to climb that high glacier and have a look at the mountain.

Returning to the camp I made arrangements to start at three o'clock the following morning, but I could not persuade both huntsmen to accompany me; and the one who did decide to come, made it quite clear that he would not do any dangerous climbing. My interpreter having refused to even climb the slopes of the mountain made the hunters think that I was mad. I was up at two o'clock and ready to start at three, but $\mathbf{H}$ 125 


\section{My Climbing Adventures}

a very thick mist hugged the ground and my hunter refused to start before four.

We crossed the frozen moraine on skis. It was my third experience on skis, and one leg persisted in going the wrong way, laying me low on the soft snow. Once over the deep snow that covered the actual moraine we went over lumpy earth for about 300 yards to the frozen lake. Continuing over the lake, we went too far to climb the glacier that we had intended to climb, so we decided to go to the end of the frozen lake and follow a frozen stream. We left our skis on this spot on the lake-side. We could not make any impression on the ice, so we took to the bank, steep, but climbable. Once on the top we had fairly level ground, although buried in snow. The skis, which we left behind us, were bound with fur, the object of which was to take a firm grip of the snow and prevent our sliding backwards. We soon regretted leaving them behind, as we sank deep into the snow at every step. Leaving the snow at last, we climbed some steep rocks, only to find ourselves on a snow slope, the surface of which was frozen over. We presently reached the lower end of the glacier, and again found the ice too hard for the 126 


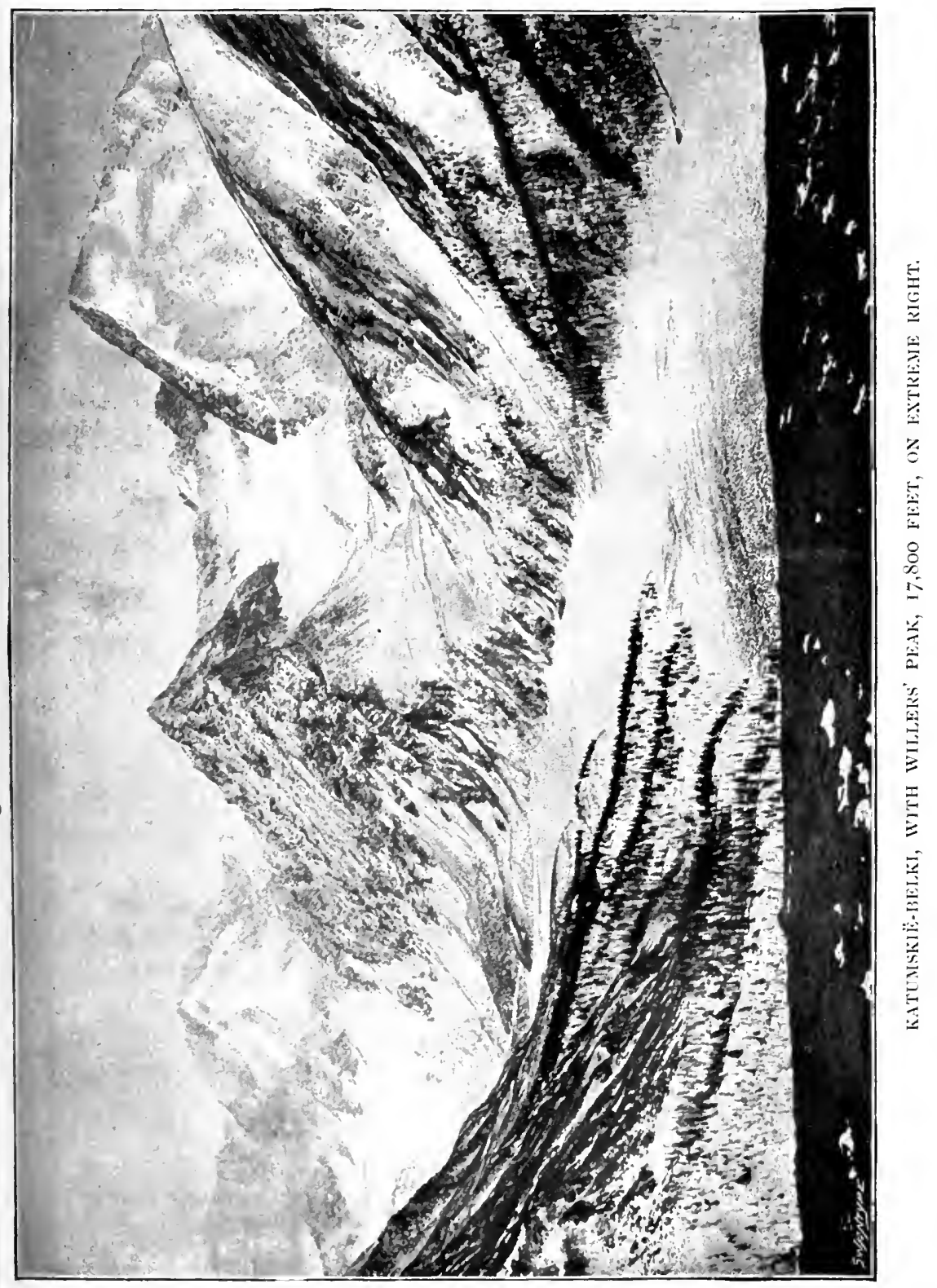





\section{Siberian Discovery and Exploration}

nails to make any impression. We were compelled to take to the loose rocks once more. We followed a zigzag course over frequent snow slopes and between isolated square blocks of rock, also covered with snow. We at last reached the top of the glacier, which we found as flat as a billiard-table, and nearly as hard as rock. The altitude was 13,000 feet. It was necessary to stamp hard on the ice to be able to walk, and even with this precaution it was difficult to move slowly along. At the upper end of this glacier, which was only about 200 yards across, there was a hanging glacier which presented a very pretty sight. The ice here was buried a foot deep in snow, and snow lay also on a steep slope to the left, which was exposed to the north. My hunter photographed me at the end of the rope, and I took another of the top of the glacier, afterwards picking out, with my Zeiss binocular, the way which I intended ascending the first slope alone, as my hunter refused to climb with me, but agreed to wait. I had the choice between a steep ice-glazed slope and perpendicular rocks to climb. I made for the rock after trying the slope; the rocks afforded some good climbing, something like the shoulder of the Matterhorn. On the top I pro- 


\section{My Climbing Adventures}

ceeded along an easy ridge, I 3,300 feet high, which led up to the summit, after passing round the head of the glacier. I took a photograph of myself by the aid of a long tube. I proceeded up snow gullies which demanded respect, owing to the presence of loose rock. Great caution was necessary in stepping from one piece to another, in order to avoid being precipitated on to the ice below. I was on the south side of the ridge; the north side was a sheer precipice, and the north-west side was one ice slope about completely free of snow at an angle of 70 degrees. The Matterhorn glacier breaks and falls on the Swiss side at an angle of about 53 degrees. The intense cold of the blizzard had plastered the side of this mountain with snow which was speedily converted into the hardest ice. The hardness of the ice is difficult to realise, and is due principally to the fact that the mountains are fanned by wind from the north, which comes across the coldest zone in the world, from the Arctic regions ; freezing everything it comes in contact with and exhausting itself on these peaks, clothing them with a translucent armour of skyblue ice of indescribable beauty and purity. There is a wealth of beauty in the snow-clad summit of the Swiss Alps when the sun is upon them, as 


\section{Siberian Discovery and Exploration}

seen from some neighbouring peak. I have gazed at Mont Blanc from the summit of the Matterhorn and at the Matterhorn from Mont Blanc, and some of the grandest views in Switzerland; but the northern face of the Katunskië-Belki range, with the crystal-clear glaciers hanging in the sun and sparkling like diamonds, forms a picture so striking and beautiful that my experience can offer no parallel to them, except, perhaps, gazing on Mount Tasman's ice slopes from the summit of Mount Cook, New Zealand. It was one of those soul-impressing views which leaves one more of Nature's pictures to be stored in the mind and realised at will. The wind was intensely cold and the mountains seemed to draw nearer. One peak was the shape of the Swiss Matterhorn, but has an obelisk of rock about 2000 feet less than that of the famous Swiss peak. This peak was draped in ice about 50 to 100 feet thick, forming a wall about 2000 feet in extent. I took several photographs of it, and could have photographed it all day. It was one of the many pictures that I saw in the Siberian Altai which I felt that the camera could not do justice to.

The beauty of the view before me, and the consciousness that I was gazing upon a scene that 


\section{My Climbing Adventures}

had never yet been desecrated by the camera, or described by any human being, were things of a lifetime, and amply repaid me for the trouble of the long journey. Here all was virgin ground. There were no passes known and labelled; no well-trodden routes to be followed; no Mark Twain had ever made the ascent of these peaks in imagination; no telescope had scaled their heights before my Zeiss binocular; no avalanche had hurled its hapless victims to an untimely death; no Alpine hut vulgarised the slopes or ridges or obscured the view of the summit; no Baedeker enumerated the guides or reduced the glories of the ascent to a matter of pounds, shillings and pence. I was in the home of the real Ovis-Ammon, the maral, marmot, ibex, bear and the red Alpine wolf. When the summer came the mountain slopes would be alive with the song of countless myriads of birds, and the hum of numerous game down to insects, unmolested by civilisation and unhunted by man.

As I climbed on up the ridge nearing the summit, the peaks I had been looking at became less prominent, because, not only was I touring over them, but other mountains extending to the northwest were also higher. On reaching the summit I was surprised to find that the highest mountains 


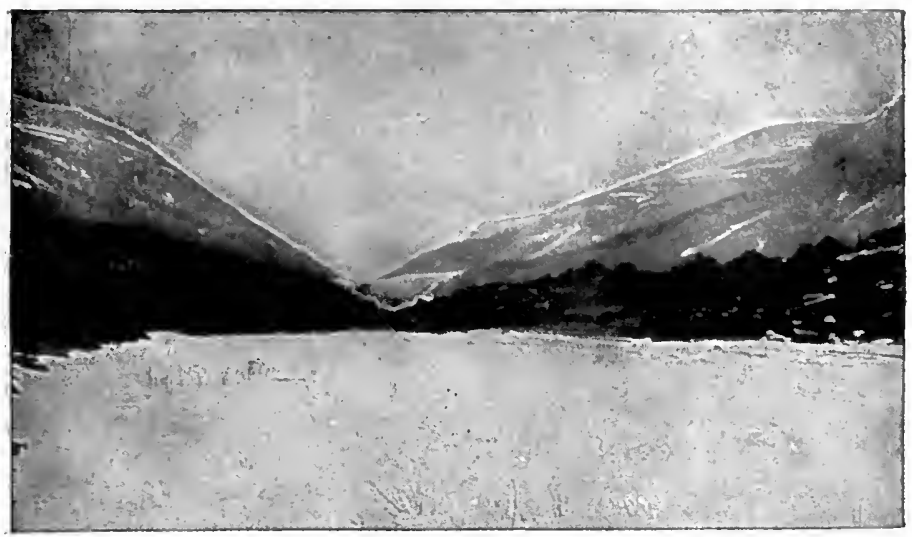

END OF FROZEN LAKE.

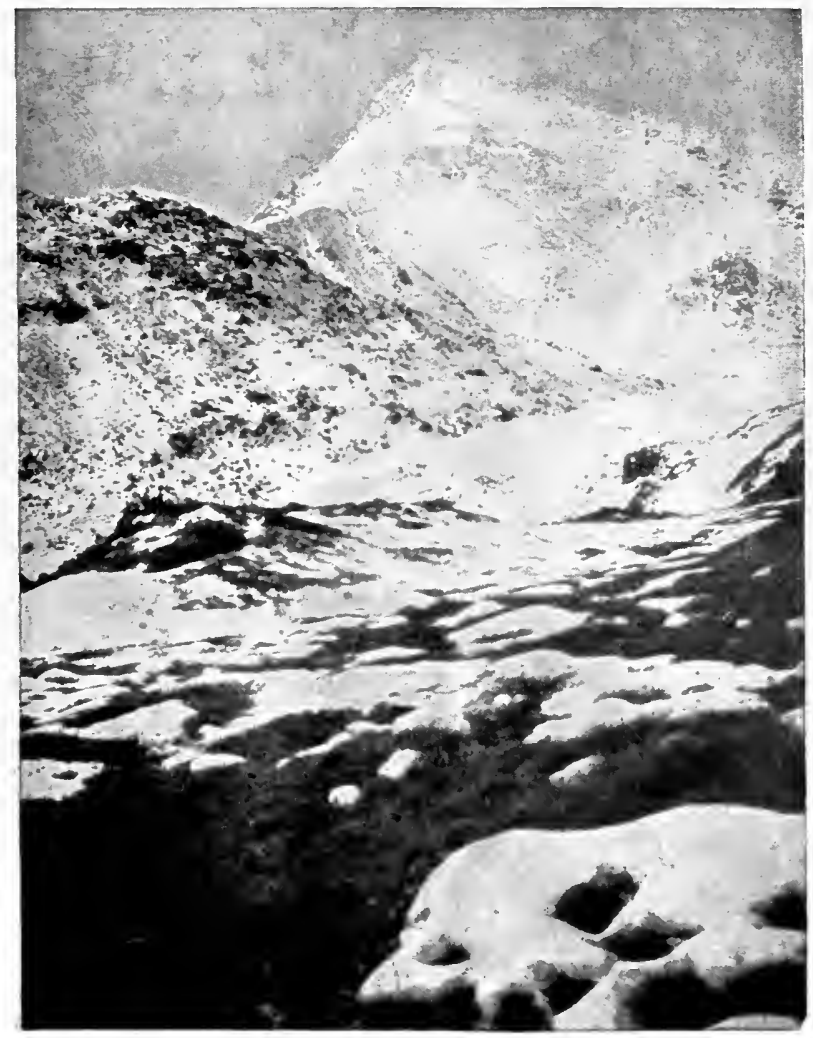

GLACIER NEAR WILLERS' PEAK. 



\section{Siberian Discovery and Exploration}

had very little snow on their summits but plenty of ice plastered on their slopes facing north-north-west. I was very satisfied with myself when reaching the summit of this unknown peak I was looking down on Mount Belukha. I placed my aneroid on a sheltered ledge of rock and the altitude of the mountain registered $\mathrm{I} 7,850$ feet; allowing the known error 50 feet reduced the height to 17,800 feet. My aneroid was tested before and after my return to England, and found to be correct. Mr Edward Whymper also tested my aneroid on my return to England. I was surprised but elated at having discovered a higher peak than the highest known up to the time of my visit to Belukha. Therefore, to make sure of its position, I took prismatic bearings and photographed the peaks all round. I also took a photograph of myself by the aid of a long tube, fasten:ng my camera on the head of my ice-axe. This method was fairly successful, but the ice-axe would or could not be fixed straight on this summit between lumps of rock, and the tilting over of the camera made me and Belukha in the distance out of focus. I christened this peak "Willer's Peak." The temperature had fallen to $12 \frac{1}{2}$ degrees of frost, Réaumur; and it would fall considerably lower when the sun 


\section{My Climbing Adventures}

went down. I wrote my name on a stiff piece of paper, in English and Russian, and deposited it under a pile of stones. The rocks at the summit I found to consist mainly of schist, felspar and hornblende; and, somewhat to my surprise, to be so brittle that I could break pieces off them with my hand quite easily.

The Katunskië-Belki form a circle of peaks, of which Belukha appears to be the highest. To the north of Belukha there are three mountains, shaped like huge fins and parallel with the glacier, north to south. The peak which I stood upon had a position from east to west. A host of thoughts flashed across my mind as I stood amid those rugged giants of the Altai. I found myself wondering whether, when the great Mogul race was predominant in Asia, some stray adventurer had ever visited these mountains; or whether they, too, had feared them, as the Kalmuck and the Moujik dreaded them to-day. This particular group of mountains is off the caravan routes from Siberia to China or Mongolia. The nearest route is that via Onguadi, the Ovis-Ammon hunters' route to Mongolia. This must be 200 miles to the east of these ranges. This fact, coupled with the isolation of Siberia from Western Europe, before the Siberian railway 


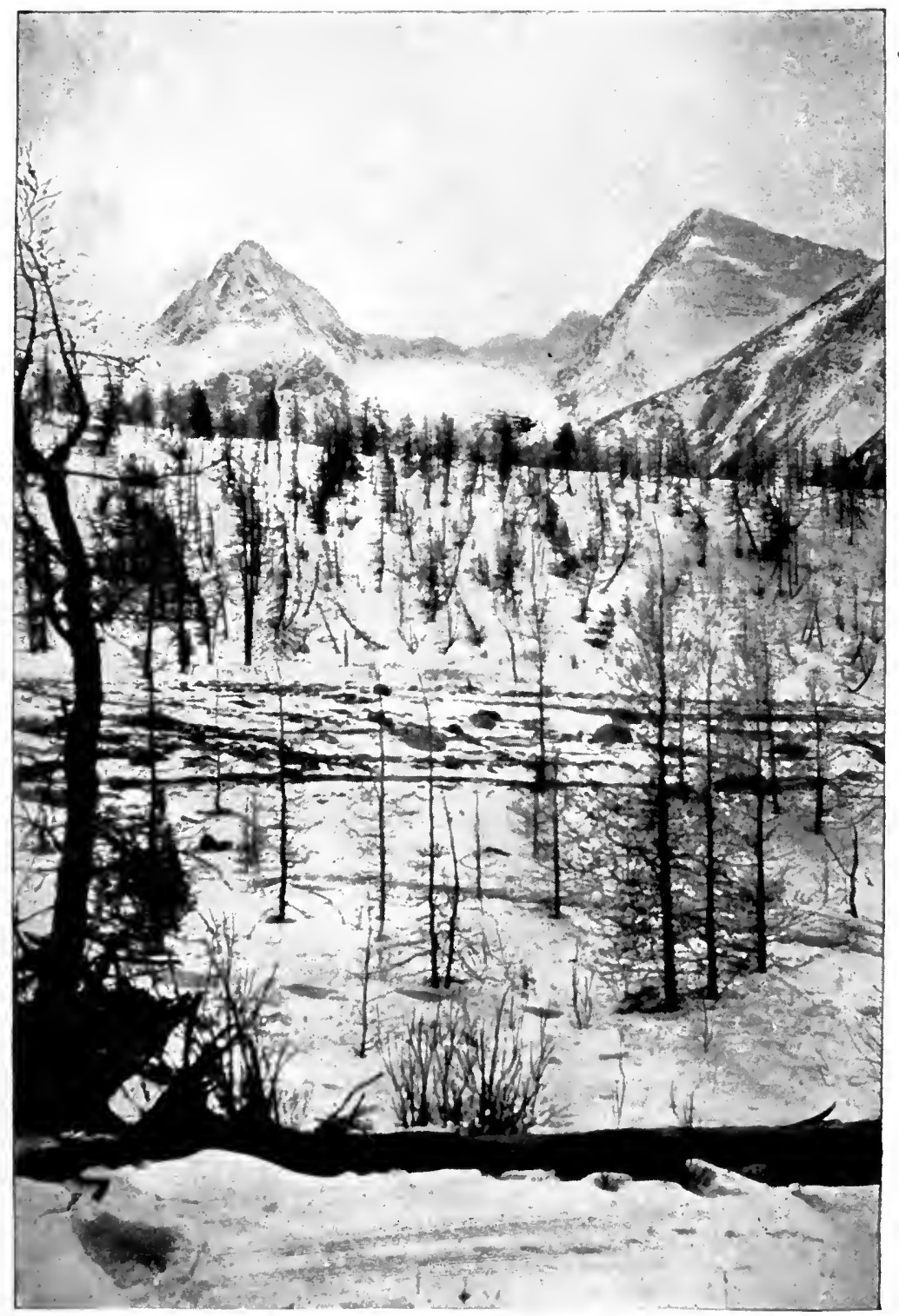

KATUNSKIË-BELKI AND LATERAL MORAINE, FROM “WINDY CAMP." 



\section{Siberian Discovery and Exploration}

line, would account for my having had the honour of leading the way to their exploration; a lead which I had hoped would soon be followed, to a land which, in many respects, far excels Switzerland in wild Alpine beauty.

There are other mountains quite as high, if not of greater altitude and magnificence than these that I have attempted to describe.

In the book on Siberia, by Geo. Kennan, p. 220, the writer who saw the Katunskië-Belki from the Omsk caravan route to China, says from the distance he could not tell how high the valley was, but he estimated the height of the mountains as 15,000 feet. He refers to Captain Marefski's estimate of their height as 18,000 feet above sealevel. He remarked they have never been climbed nor measured, and nobody knows the height above the sea or the valley bottom from which they rise. These remarks confirm my opinion that there are higher mountains to the north-west of Willer's Peak, because from the highlands whence Geo. Kennan saw the mountains, he would see the mountainsystem, if not the actual mountains I saw from Willer's Peak, which extended 40 to 50 miles to the west. At the time I was writing my book I had not read Geo. Kennan's book on Siberia; but 


\section{My Climbing Adventures}

it was written four or five years before mine. Other mountains have been discovered in Chinese Turkestan since my climb.

The word Altai means gold, and golden mountains they appeared to be as they reared their mighty crests in the rays of the slowly descending sun; and later, when the after-glow rested upon them, the scene was such as no Alpine sunset can reproduce or emulate, beautiful though the peaks, like the Matterhorn, are, under like conditions. Not a bird sounded its call, no rippling stream was to be heard, no avalanche raised the echoes with the thunder of its fall, no Alpine cow-bell sounded in the distance; no glacier cracks could be heard, nor the flowing of water under the glacier - everywhere was silence, a silence that could be felt. Yet, in the silence, the stately mountains seemed to welcome me and to invite a closer acquaintance. The frozen glacier stream and river lay in its winter sleep beneath me; the lakes in thin ice-sheets slept peacefully beyond. In the distance were the pure white snow-fields, kissed by the sky in their complete loneliness. Around me scores of glaciers clothed the slopes and precipices.

The summits dreamt in the glow of the closing day. The sky was clear and of a beautiful blue 


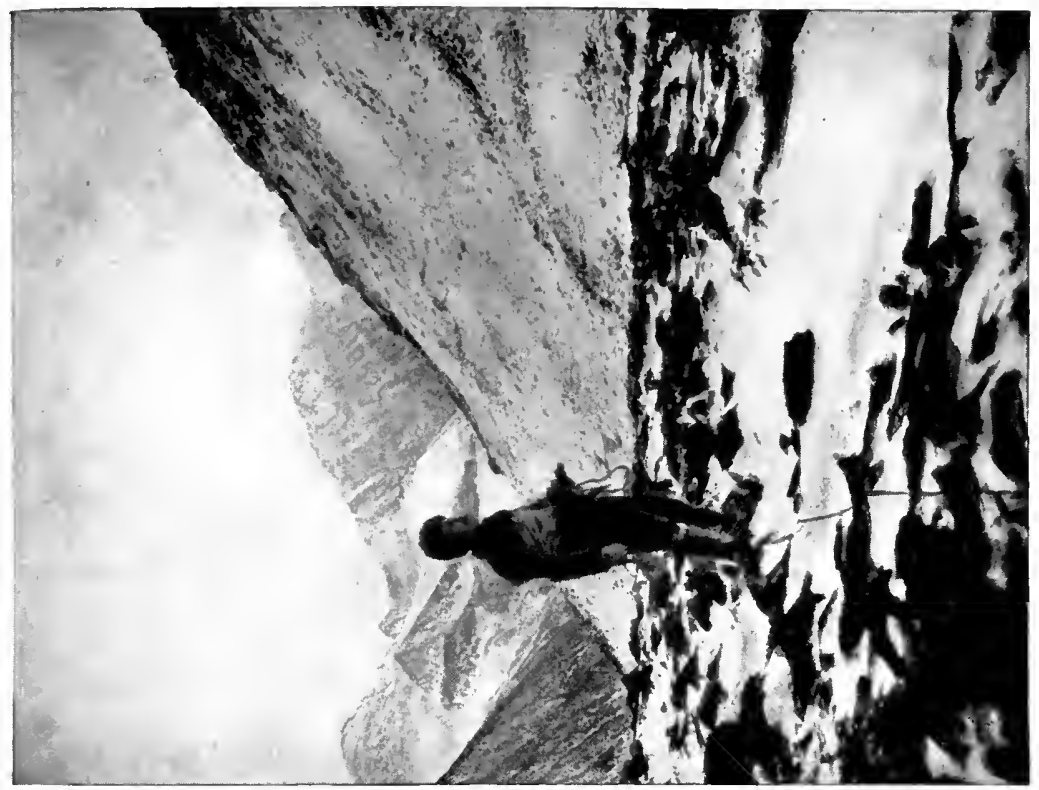

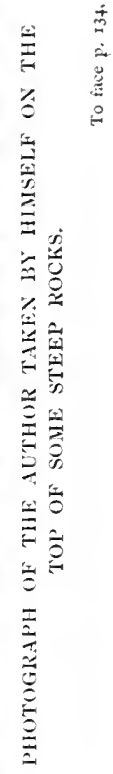

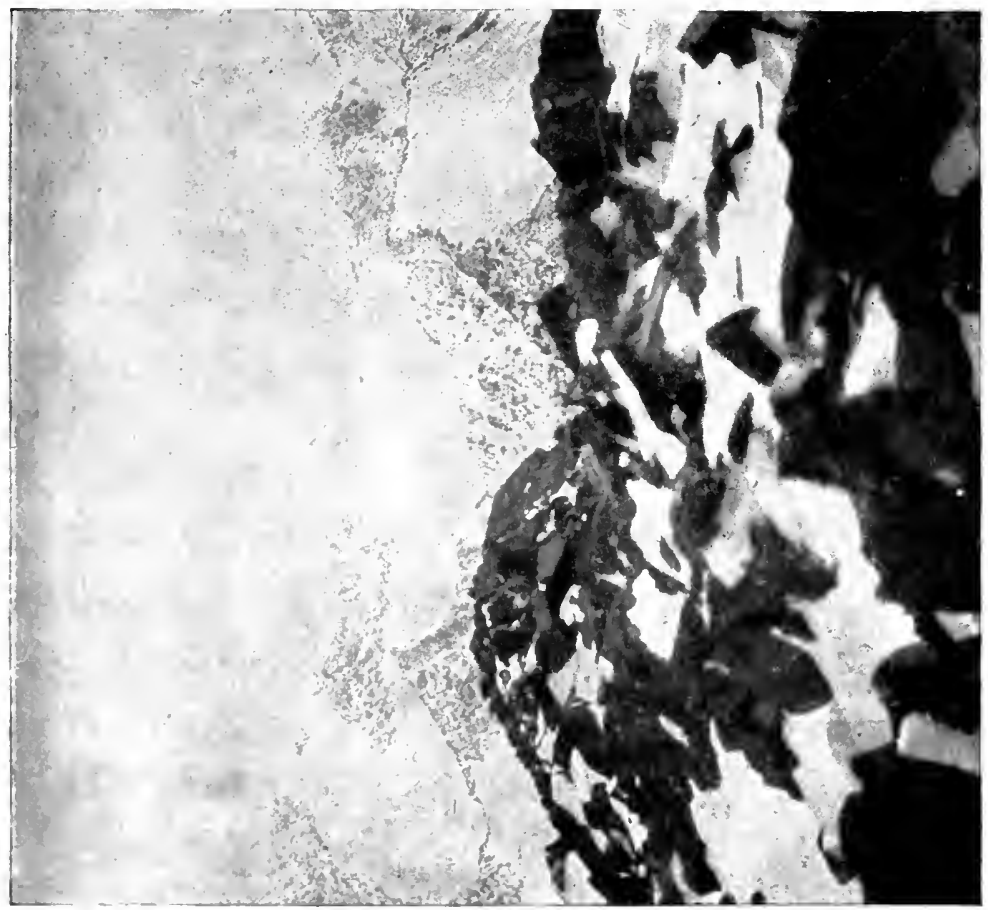

 


\section{Siberian Discovery and Exploration}

tint to where it kissed the snow and purified its colour still further.

I felt that my journey had been more than repaid by this brief spell of glorious essence of life. Surely life is only measured by the quality of its moments which leads men into all kind of difficulties and delights: so I felt that two hours of such glorious essence of life was worth ten years of life amidst the hustle and scurry for wealth in other parts of the world. I hope the day is coming when fast electric power will transfer people to these mountain regions, and the highlands and mountains of the Altai will become a sanatorium. If man wishes to cure his fellow-man of the white scourge, tuberculosis, the Siberian Alps are the places where this can be done. Who can say but that consumption in its different forms is the natural outcome of man not using the purest parts of the earth for the benefit of mankind?

With the mountain fever within me more intense than ever, I was compelled to commence the descent of the mountain. After three hours' climb I reached that part of the mountain where I had to choose between a vertical precipice and the risk of starting an avalanche down a very steep ice slope. I was too tired to climb down 


\section{My Climbing Adventures}

the rocks or even walk down the slope, so decided, rather than stay on the mountain and freeze, to trust to Providence and let myself slide down on my back, putting my ice-axe under my left arm. I lost control of myself, but threw away my ice-axe to prevent myself becoming impaled on its sharp spike or head. With the exception of losing a little skin, I landed on the glacier below without accident. I secured my ice-axe and decided to try the sliding on my back down the glacier, and it worked all right. I met the hunter at the bottom of the glacier, and was glad to unload some of my equipment on to him. It was the sledge-travelling in a cramped position and climbing with such a heavy load on that made me so very tired. Besides double underclothing, a thick climbing suit and thick seal coat on the top, I had binoculars, prismatic compass, aneroid, Alpine rope, rucksack, containing camera, change of clothing, etc. Climbing a mountain weighted like this, without having more than one day's preliminary walk, was a great tax. We put snow-shoes on to cross the lake and lateral moraine, and I had a few headers in the snow for not having tied my skis on properly. I was glad to reach the tent, and although I had only been away for a seventeen hours' climb, I was I 36 


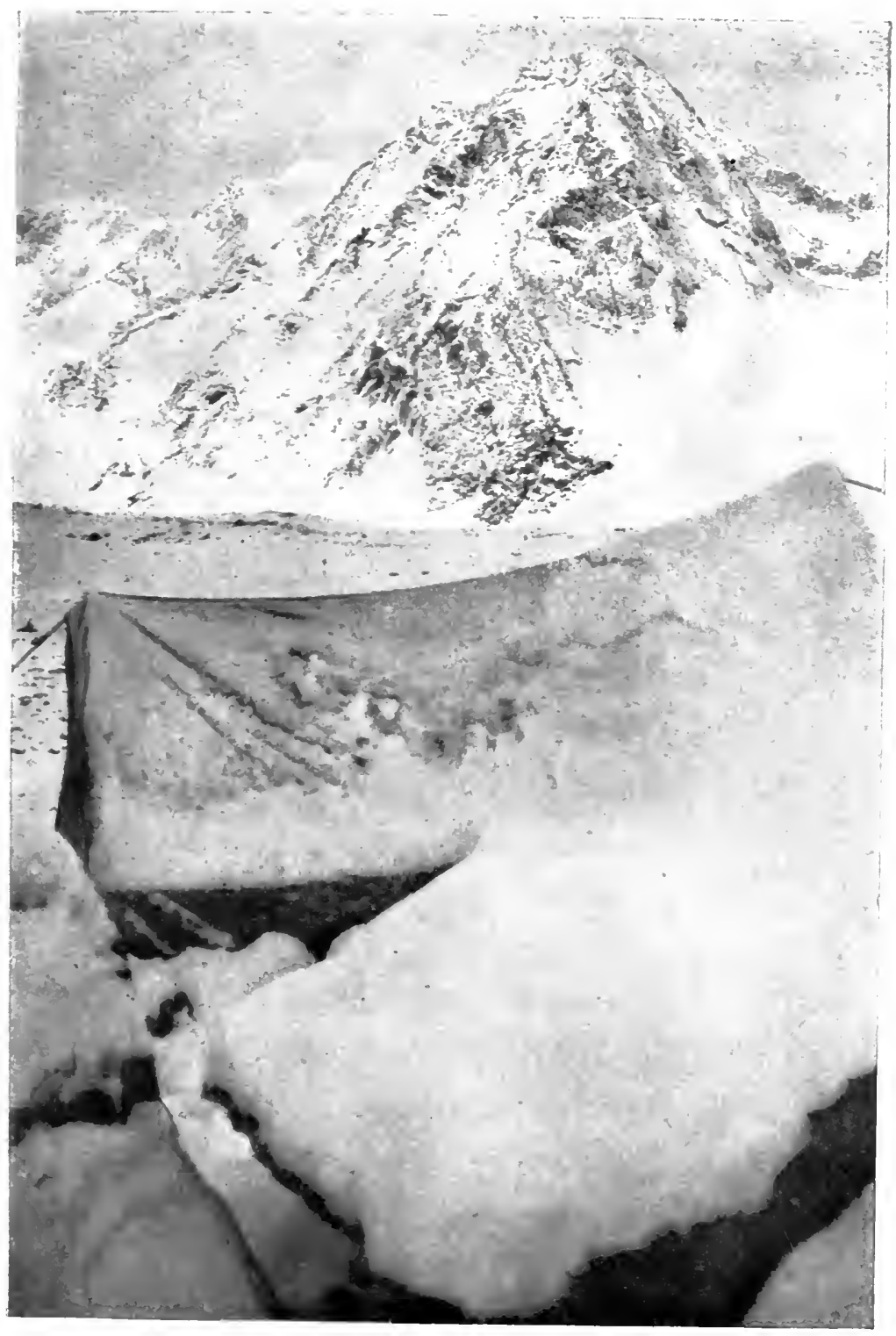

SNOW-13OLNI) TENT AND LNAMED PEAK, AT 4 A.M. 



\section{Siberian Discovery and Exploration}

thoroughly exhausted. At dinner-time my interpreter had to wait on me, or I should not have had enough energy to take food that night. Although I was previously very much annoyed with my interpreter for not accompanying me on the climb; after the kind way in which he looked after me that night, I forgave him for not risking his neck on the mountains.

One of the Kalmucks, whom we met at the last Kalmuck hut, was sitting round our fire when I returned. When my interpreter made me a cup of tea, the Kalmuck handed me a piece of sugar; but after the second cup of tea I found it was a piece of white marble, much to the merriment of the Kalmuck and my party. Our tent had been blown down by the fierce wind, so we all slept in the open that night. The horses became restless and frightened, and came in near the fire. The hunters said that there must be wolves about, and the horses had evidently seen them ; so we piled more wood on the fire to frighten them away, and made sure that the guns and revolvers were all charged. Wolves or no wolves, it did not take me long to roll myself up in my shuba and fall off to sleep. I slept until about 9 A.M. the following day, which was given up to 


\section{My Climbing Adventures}

hunting, and I secured trophies in the shape of ibex horns as follows: Large horns, 42 inches long and Io inches thick; second horns, 25 inches long and 8 inches thick; third horns, 23 inches long and 7 inches thick. The southern and western slopes of the Altai range, which are hunted by the Mongolians, are becoming exhausted, the animals being steadily driven to the more remote valleys and secluded gorges in this mountain district. The Kalmuck informed me that the horns of some of the ibex he had shot were much larger than the largest secured by me.

It is to be hoped that some English sportsman may be induced to visit this part and find out if it is not possible to secure the largest ibex horns in the world.

On the slopes of the mountains I had climbed, both the Saptam Mountain and Willer's Peak, there were skeletons of maral and bear probably frozen to death. 


\section{-}




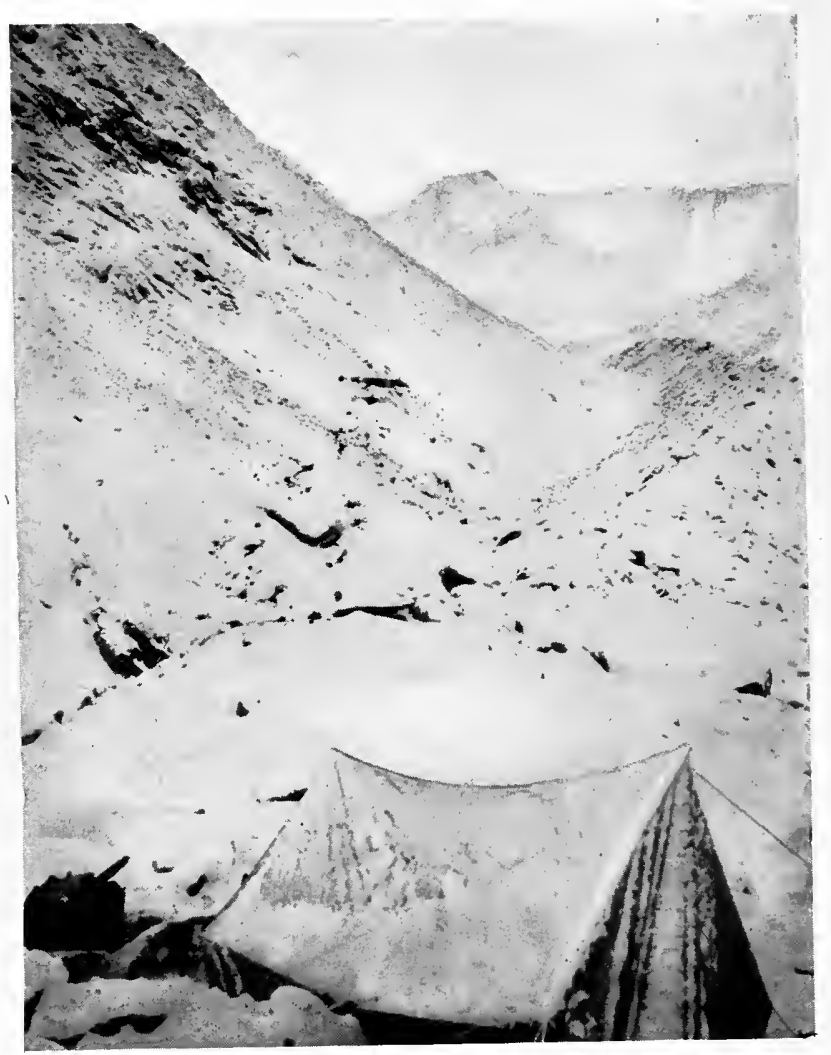

"DESOLATE CAMP," TENT ON MORAINE AND BELUKHA WEST PEAK. 


\section{CHAPTER VII}

CLIMBING BELUKHA-A NARROW ESCAPE OF BEING CARRIED DOWN THE MOUNTAIN BY AVALANCHE

THE weather on the following morning was 1 very cold, calm and promising. The thermometer registered 45 degrees below freezingpoint, and there was every prospect of a good climb.

It was my intention to move the main camp as near as possible to the mountain, but the hunters refused to go as far as I wished. I explained that the distance from our present camp to Belukha was 8 miles; and, owing to the very difficult moraine, and the peak being quite unknown to me, it was absolutely necessary that we should move the main camp much nearer to Belukha. The hunters were afraid that there was no wood for a fire, and that we should be frozen to death. I told them of a number of fir-trees at the base of the glacier which I had noticed the day previously, and said I was quite sure the spot was much better than "Windy Camp," as we should be protected 


\section{My Climbing Adventures}

by the peaks. All my arguments were of no avail. Everybody had warned the interpreter and these hunters against the danger of being frozen to death, the common peril in Siberia, so my interpreter as well as the hunters were determined not to take the risk. After a lot of talk, it was agreed that we should camp on the side of the lake I mile nearer Belukha. We packed our equipment on the horses, but had great difficulty in getting them over the deep snow of the lateral moraine, at which the hunters complained very much. We soon reached the lake.

The water had evidently flooded the top of the lake and frozen again, because it broke and let the horses' hoofs through for about 6 inches at each step: the ice underneath was very hard. Just as I thought we were getting on splendidly the hunters made for the side of the lake; and, when. I informed them that we must at least go to the end of the lake, they threatened to go home and leave me, unless I allowed them to have their own way. They both argued that even if I went to the end of the lake, I should not be able to reach the peak in one day, and they would proceed with my light tent as far as I wanted. This being the best I could do, as soon as we made the second camp I 40 


\section{Climbing Belukha}

I intimated that I wanted to sleep on the top of the glacier at the foot of the Belukha precipices that night. Continuing on our way, we rode the horses to the end of the lake and tied them up to the trees.

When we started from the camp at about II A.M., the hunters were willing to carry out their promise to take my tent to where I wanted to sleep; but they soon got into difficulties on the moraine, slipping off the ice-glazed boulders, sinking up to their hips in soft snow, and getting their legs jammed between boulders. They soon wore a look of disgust on their faces.

I had anticipated that if I did not carry part of my luggage myself, they would complain of their loads being too heavy, so I had taken as much as either of them, and when they began to complain I reminded them of that fact. I also quickened my pace and left them some distance behind.

When we left camp the weather was very cold, with wind blowing from the north. The sky was clear and blue. An hour later, as we were making our way up the moraine on the left, the wind changed and snow began to fall, and my companions became anxious to return; but I argued and cajoled, and finally prevailed on them to go on. We 


\section{My Climbing Adventures}

proceeded for another hour, when they finally struck, although it was next to impossible to camp on that moraine. We had only covered two miles out of six which was necessary, to camp at a convenient spot from which to climb the mountain the following morning. My arguments were of no use, however, for, suiting their actions to their words, they both put down the luggage and were about to leave me, when I agreed that if they would help me to find a suitable place for the camp, they could come up at 4 A.M. in the morning and carry it to the base of Belukha, which they solemnly promised.

They took up the luggage again and followed me for a little while, but there was no place for a camp. I wanted to take them a little farther, when they insisted on my choosing a spot close to where they sat.

The rest of the moraine was quite as desolate, so I turned over as many boulders as possible to get the drier side. After scraping away the snow and levelling up the boulders, I found that there was no possibility of driving pegs in between them, so I had to tie large stones to the cords of the tent and pile others round to protect it against the wind, which might cover me and the tent with drift-snow. The hunters, who complained of the cold and snow, 


\section{Climbing Belukha}

turned back, and left me to complete the fixing of the tent and its interior myself. I was soon very stiff and cold with the bitter wind and snow driving against me, and was glad to crawl into my small tent, lay my big coat on the boulders, unpack my knapsack and make ready to light the spiritine lamp (my only hope of keeping myself from being frozen).

I was surprised and not a little concerned to find that the spirit had all leaked out of the lamp. I was beginning to realise the awkwardness of the situation, when I recollected that I had taken a few small tins containing blocks of spiritine as a precaution, little thinking at the time how very valuable they were going to be. $\mathrm{My}$ feet and legs began to freeze in my Alpine boots; the big Alpine nails in which seemed to conduct the cold to my feet. I took them off, just in time to restore the circulation and put my valenki on instead. Then I lit two small blocks of spiritine, after thawing the tops with a match.

I peeped out of the tent, feeling that if the snow stopped I would return to the main camp and make a fresh start in better weather; but the snow and drift-snow caused by very strong cold wind made any return out of the question, so I tied up the 


\section{My Climbing Adventures}

opening of the tent, and determined to take what came. I felt quite abandoned if not caught in a trap. Fully realising my helpless position and all the discouragement I had received at the hands of all the Siberians I came in contact with, I grew still more intensely determined to push on and succeed in climbing Belukha at any cost. I then boiled a tin of soup, drinking it eagerly to warm myself. Supper over (I call it supper, because I was going to try and sleep and forget the storm raging outside; the time was about 5 P.M.), I left one block of spiritine burning, and rolling myself carefully in the fur coat and pulling my fur cap down over my ears, I lay down on the stones and tried to go to sleep, vainly, for the howling wind was doing its best to tear up my little shelter from its moorings.

I lay, expecting to find myself in the midst of the driving snow with the tent cantering over the moraine, but nothing happened for a while, so I began to congratulate myself on the way I had piled the stones and boulders round for protection; and shortly afterwards, amidst half-conscious reveries, in which I wondered whether I should survive the intense cold, and get to the top of the peak and back to dear old England again, I fell asleep. 


\section{Climbing Belukha}

I awoke suddenly about midnight, with an icy shiver, as though I were lying in a cold bath. The block of spiritine had burned itself out; and in my sleep, dreaming of home and mountains and ibex, wolves, bears and snowstorms, I had kicked off my fur coat. It took me quite a while to restore the circulation to my frozen limbs, which at one time looked as though they were badly frost-bitten. I decided that it was too cold to risk going to sleep again. I lay thinking; wondering how I should succeed in making the ascent over all that fresh snow. Nature, however, proved stronger than my determination, and I presently dozed off to sleep once more. I must have slept for three or four hours, for when I awoke day was breaking; it was about three o'clock in the morning.

I reached for my boots and found that they had frozen very hard and that I could not get my feet into them. My feet were also swollen. I thawed the boots by lighting a block of spiritine, and managed to squeeze my feet into them. My body was very stiff after sleeping upon these boulders. I consulted my watch and found that I had been in the tent thirteen hours, during about ten of which I was asleep on the boulders. I named 


\section{My Climbing Adventures}

that camp "Desolate Camp." I opened the tent and crawled out, brushing the snow away from the boulders as I did so. It had fallen to the depth of about 6 inches during the night and was falling still. The wind had dropped, however, so I decided to turn in for another hour to see if the weather improved.

Looking out of the tent some time afterwards, and finding that the snow had ceased and that it was lighter, I decided to make a start, if the hunter did not come by the time I had taken a round of photographs. The peaks were just receiving the first rays of the sun, but the air was so actinic that I decided to try and get photographs showing the shadow as well as the sunlit peaks, together with photographs of my little tent, which was covered with about an inch of hard frozen snow, almost as hard as ice, which could not be chipped off my tent very easily. The boulders all round the tent were covered with hard ice. It was evident the freezing of my tent had prevented it being blown away. The boulders that I had turned over the night before to fasten the guide-ropes of my tent were also glazed thick with ice. I decided that it was too risky to sleep in 


\section{Climbing Belukha}

that little tent another night. The hunters had promised to be up by four o'clock, but it was now about five, and there was no sign of them; and as I could see it was no use relying upon them to take my tent nearer Belukha, I decided to try and climb Belukha from this tent, and get back that same night to the main camp.

I took as little luggage as possible, and proceeded over the ice-glazed boulders. I have had considerable experience in scrambling over Swiss boulders, and could consider myself well practised in the knack of gliding or skipping from one boulder to another with considerably more than the average amount of balance and agility; but the boulders which form the moraine of the Belukha Glacier were not only glazed with hard ice, but were made to appear all level by the snow being blown over them, filling up every space between them.

To avoid sinking up to the hips in the soft snow that lay between the boulders it was necessary to jump from one to the other of them and trust to luck that the raised part of the snow was covering a boulder. Nine times out of ten it did cover a boulder, and when I lit on it I had at times the greatest difficulty in sticking there. I found the 


\section{My Climbing Adventures}

Mummery steel nails in the heels of my boots very useful; but I was deceived repeatedly by snow raised as though there was a boulder under it, though there was nothing there but soft snow. On such occasions I had to let my legs go down between boulders and had to break my fall by all kinds of twists and turns. I found the safest way was to let myself fall forward on my hands but sometimes I had to fall backwards. When my limbs began to ache I tried the glacier, but each time I found progress up the hard ice too slow. The ice was too dense for crevasses, but after walking up the slightest incline, if I was not very careful, I would slide back again. On one occasion I glided down to the side of the glacier as though I had been shot out of a gun. It gave me such a shaking that I took to the boulders again. As I plodded my way to the top of the moraine the boulders became looser, and continually the one I jumped on to would vanish down between the others. If I had not been quick enough to fall forward or sideways each time flat on to the snow, I should have been crushed in the holes which the boulders made. I had to sit down to feel if my ankle was strained or knee twisted, and after some massaging I proceeded with my acrobatic perI 48 


\section{Climbing Belukha}

formance, and every time I came to grief the peaks seemed to be laughing at me and alluring me on to a more desperate jump; the most trying thing was to find that I had to either try and struggle between boulders or jump back again and round another way. When the boulders were near each other I could step from one to the other, but they seemed to be so large that the tops were quite 3 feet apart in most cases. After a very, trying time on one particular part of the moraine I sat down on a boulder as flat as a round drawing-room table, quite 6 feet in circumference and 3 feet across.

I unpacked my rucksack and made a good meal. I had been compelled to leave everything except food behind me on starting out over the moraine; and now I could see by the Belukha precipices that if I succeeded in climbing them without a rucksack I should be very lucky. Whilst resting on these boulders I heard a noise, and looking down the glacier I saw the hunter, who afterwards turned out to be Cherapanoff, about 3 or 4 miles away, beckoning for me to go back.

I had heard quite enough from the hunter about the dangers of the mountains, and as the clouds seemed to be drifting up towards me, I 


\section{My Climbing Adventures}

thought he was trying to warn me of the coming storm. The clouds which were descending from the peaks all around me made me hurry. I was able to get my aneroid into my pocket, but was compelled to leave the rest of my luggage on this table-like slab of rock.

I first of all tried a gully up the precipice of Belukha, but the rocks were too ice-glazed and, after close examination, I concluded that it was quite impossible to make the ascent that way. I turned back to some steep rock which, I concluded, led to the ice ridge, and for about an hour climbed up slabs and wriggled up cracks. The snow and ice gave me trouble and it presently began to snow, as I reached the east ridge, which measured I 3,800 feet. I left my card under a piece of rock and proceeded through the fast-gathering mist towards the higher ice ridge. This ice ridge is very much like the ice ridge on Monte Rosa, near the summit of Dufour Spitze; not quite so steep at first and covered with soft, powdery snow, but after about 800 feet it became hard ice. I had attained a height on this mountain that nobody had attained before me. Professor Sapozhnikoff had gained I 3,300 feet from the south side in the summer-time, but it was altogether another matter in the winter, 


\section{Climbing Belukha}

and the hurried climb along that tantalising moraine and up the northern precipice of Belukha began to tell on me. I was, however, so exhilarated on being close to the summit, that I felt like making an attempt to run up the last 500 feet of ice slope, but the ice was too hard and at an angle of 35 to 40 degrees.

I commenced to cut steps, but found the ice exceptionally hard, and it took me nearly half an hour to make a decent-sized step. The largest piece I could chip out of this ice was about the size of a walnut, and I knew the climb to the summit was impossible under these conditions, so I stood to think about fresh plans and take in the view.

To the north was a circle of mountains, and while I was there several avalanches fell off the peaks to the north-west of Belukha on to the moraine and the glacier up which I had come. The weather was unsettled, but the snow had ceased falling. Turning to look along the glacier, which was about 8 miles long on the south side of Belukha, I could also see a large number of snowcapped peaks, all of less altitude than Belukha. Everywhere there was fresh snow. The ridge on which I stood was rather dangerous, as the hard ice 


\section{My Climbing Adventures}

with which it was coated would not allow the nails of my boots to get a good grip.

The view of the twin peaks forming the summit of Belukha looked very beautiful glittering in the sun, and filled me with an irresistible desire to climb it ; so although badly in need of a rest, I continued to cut steps in the hard ice. I was soon convinced, however, that it would be impossible for me to reach the summit that day, especially as I had nothing with me to shelter in while I slept on the ridge. The north face of the precipice, near which I was standing, was glazed with ice, which rendered the few cracks and hand-holes, that might be there, quite useless. On the other hand, even had I been able to climb that part of the mountain, it would not have been possible to get further than the west side of the ridge. The only way for me to take was the one I had taken. Therefore, for the first time, I realised that I could not get up the west peak from any other part of the different ridges. It was quite out of the question to continue up the ice ridge ; and to take the more gradual slope on the south was to take a very great risk of sliding down with the snow.

I looked at it as carefully as possible, and decided that although I might slip, the snow did 152 


\section{Climbing Belukha}

not seem more than 2 feet deep, and there was not much danger of being smothered with an avalanche.

I had come far and had taken the risks of escaped exiles, wolves, bears, and the intense cold. Therefore I did not intend to allow one more risk to deter me. Walking carefully enough for a few yards, it looked as though I had done the right thing; but a second after making this decision, the snow began to move, and I with it. I steered myself with my ice-axe for a yard or two, when I lost all thought of everything except that I was being carried to destruction. I turned head downward and stopped, the snow closing over me; but I was able to knock the snow away from my head, and I found I could breathe all right. I had luckily retained the grip of my ice-axe, and this stopped me from gliding further towards a precipice. Pulling on the ice-axe I managed to get on to my knees and free from snow; then I found myself a few yards away from a sheer drop of hundreds of feet; and I was just on the edge of a steep slope, which would have hurried me over the precipice. A lucky piece of rock had stopped my progress.

I crawled on my hands and knees carefully after making fast with the head of my ice-axe. I occa- 


\section{My Climbing Adventures}

sionally slipped and had to let myself lie flat to stop myself from commencing to slide again.

It was during this time that I tried to make a fresh grip with my ice-axe that I began to slip. I now remembered my knife, so I got it out and opened the short tin-opener blade. This was a great help, and with its aid and that of the axe, I managed to regain the ridge. It seemed to take a second to slide down and about two hours to crawl back; the distance was about 60 feet. I scraped lots of snow out of my neck, but a good deal of it melted there and gave me a cold bath. After my pockets were cleared and clothes shaken out, I felt very cold and wet. To keep up the circulation, more than with any idea of attempting to climb the ridge again that day, I decided to cut as many steps as possible, and come back the following day. The wind began to blow from the north, intensely cold, and this made me abandon step-cutting and hurry off the ridge as fast as I could go. My clothes stiffened upon me, and at one time I felt that I was going to lose the use of my hands. I rubbed them with snow and began the descent; but the wind had glazed the rock with ice, and I was a very long time climbing down: even so I had to exercise the greatest caution. 


\section{Climbing Belukha}

The climax came when I found myself above a gully which required to be climbed down, and appeared to project. I had not climbed up it, so concluded I had missed the route by which I made the ascent. I stuck in that gully, carefully calculating whether I could let myself drop with safety on to a ledge, about 2 feet wide, covered with snow and slightly slanting outwards, some distance below me. I knew that if the ledge was ice-glazed I should certainly slip and fall down the mountain, but I was unable to get back.

I persuaded myself that the ledge was protected from the north wind through being in a northwesterly position, and at last I let myself drop. As luck would have it I was able, just as I landed on the ledge, to grasp a projecting piece of rock which had been invisible from above. The remainder of the climb was easy-it was below the exposed part of the ridge and the rocks were not ice-glazed. I was glad to scramble down the last steep rocks and recognise the spot where I had left my rucksack. Shouldering it, I started on my return journey. The temperature on the moraine was 18 degrees below freezing-point. I found it very difficult walking, as I was getting very tired, and I became aware of internal pain. The pains developed, 


\section{My Climbing Adventures}

and I decided that I had either contracted a severe chill or had eaten something that did not agree with me.

I could not give up on that desolate moraine, because I should never have been found. I seemed about a million miles from England, and progress over the moraine became more difficult, or appeared to be more difficult.

It required all the will-power and patience I could command. At times I was completely exhausted; and my legs became so strained and sore with slipping down between the boulders that I felt I could not stir another yard. After a brief rest I plodded on again. I was delighted to see my little tent on the moraine, and when I reached it I found my hunter resting quite contentedly with his back to the tent and with my overcoat over him to protect him from the cold north wind that was blowing. He was very pleased when I told him to pack up, and was not long in taking down the tent and packing the remaining things together. $\mathrm{He}$ explained that he had managed to get so far alone, but that the other hunter had been afraid to come. He spoke as though he thought he was brave, and as he had never been on a moraine or glacier before, no doubt credit was due to him for following 156 


\section{Climbing Belukha}

me. He pointed to a hole in the glacier which he narrowly escaped tumbling into. $\mathrm{He}$ also expressed his opinion that he was sure that if he had tried to follow me he would have been killed. He showed nasty bruises on both his legs, and by the way he had fared on that short journey I considered myself very lucky not to be more damaged.

From enquiries I made afterwards, I found he had been four and a half hours covering the $2 \frac{1}{2}$ miles to the tent; but his interest had been attracted by a huge bear which he had encountered by the trees at the bottom of the moraine; and which he had tried to kill with his large knife. It appears that the usual way of killing bears in that part is to let the bear run at you, and just as it is going to spring you get behind your long knife, lying flat, and so the bear impales itself on the knife. He explained that the bear ran when he got near to him, and that he vanished into the mountain pass. He showed me what appeared to be the track of the bear, and I considered it was a good excuse for his not having followed me. Curiously enough, the hunter was not at all afraid of the bear, and explained that he had killed several with his large knife alone; but he admitted he was afraid of the mountains. The hunter's assistance and companionship was quite 


\section{My Climbing Adventures}

necessary to enable me to get back to the main camp, which we reached that same evening.

My interpreter remarked that I looked very unwell, and I was very sick for about an hour. After thinking over what had made me ill, I decided that I must have swallowed some solder from the tin which contained oxtail soup, which I had drunk so hurriedly in the little tent. I have no doubt also that the snow and ice-water we had been drinking, and the poor bread we were eating, together with the tinned food, had something to do with my illness. I went to sleep by the fire with my back to it. During previous nights, sleeping in our fur coats in front of a big fire we kept warm enough; but this night the wind blew a hurricane and the thermometer was very far below freezing-point. 
$\because$

. 


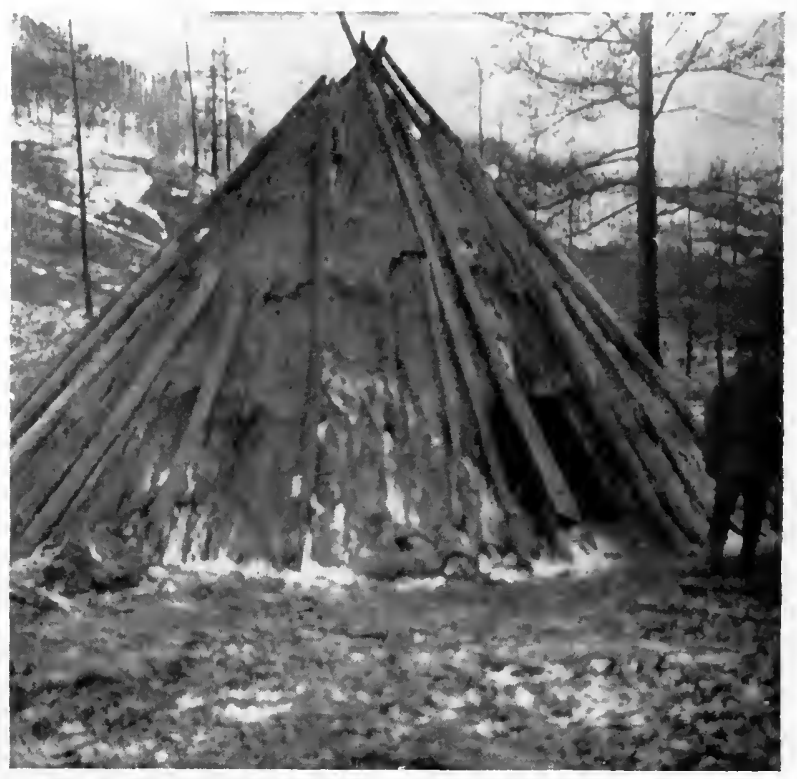

KALMLCK BARK HUT, AKKEM VALLEY.

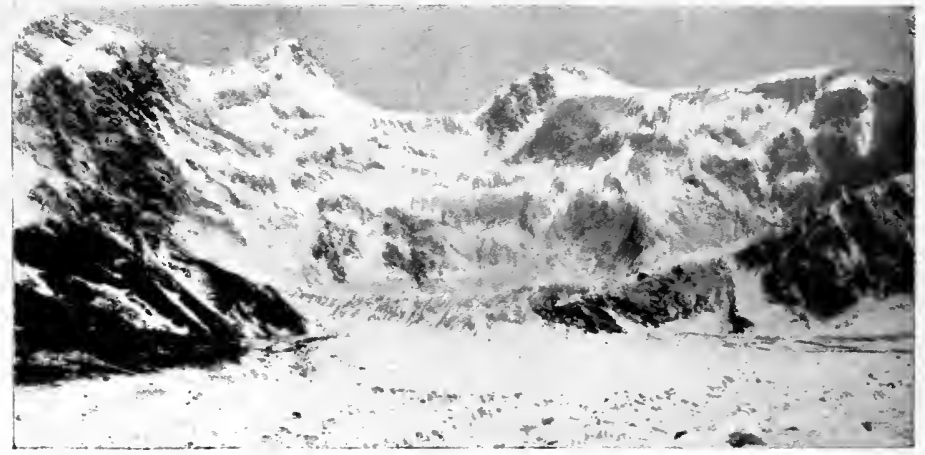

NORTH FACE OF BELUKHA FROM GLACIER, TIVIN PEAKS, I4,800 FEET. 


\section{CHAPTER VIII}

I AM COMPELLED TO GIVE UP; AM POISONED, AND HAVE INFLAMMATION OF THE EYES

AWOKE very early in the morning to find
that my eyes were closed tight with inflammation, and that I could only bear to open them for a few seconds at a time. As soon as daylight appeared I gave the order to pack up, which was gladly obeyed. My illness and the state of my eyes made any further climbing out of the question. I was very disappointed to leave so many virgin peaks unclimbed, but there was nothing for it. We rode the first 20 miles in a bitter cold wind and through a driving snowstorm, sheltered only by trees. My eyes were very painful, and I could only see for about five or ten seconds at a time, consequently the branches of the trees between which we had to push our way swept across my face, leaving severe scratches; one branch took a piece out of my nose, and has left a mark to remind me of that ride all my days.

The faces of the party were nearly frozen by the I 59 


\section{My Climbing Adventures}

wind. The ibex horns on the horse's back, and the leather bags on the side of the horses, knocked against the trees and shook them as we passed, and the snow dropped upon our heads and sometimes down our necks. We tried to find our former track, but the snow had obliterated all traces, and we were very uncertain at times of the direction in which we were travelling. The horses fell frequently during this part of the journey and required a lot of pulling up on to the track again; and every time this happened the luggage required to be repacked. It was a pleasant relief when we reached the Kalmuck hut and were able to obtain shelter and dry our clothes. An iron slab in the centre of the floor of the hut held the boiling pan, and a Kalmuck girl was grinding rusks to powder to be boiled in milk. Her mother lay ill on the wooden bed at the side of the hut. Over her bed was the icon, and the pigtail f one of the men had been shaven off. Other signs proved that the Kalmuck had been converted to Christianity. I had an opportunity to study the character of these nomads of the Altai, and, from observation and inquiries which I had made, I am led to believe that they are the most natural and unaffected people in the world. They are very calm and alert, and are particularly friendly in their res6o 


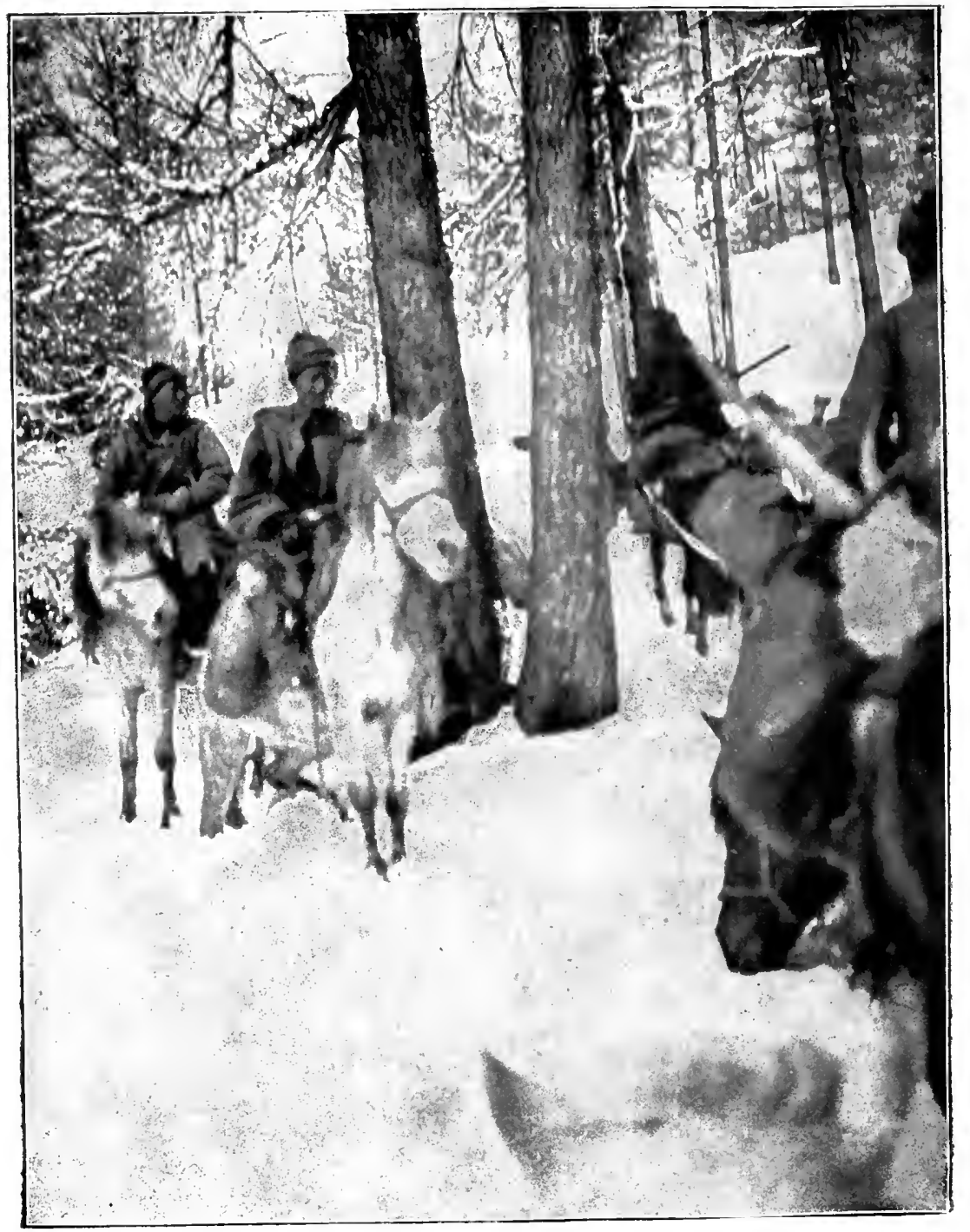

KALMUCKS ON AKKEM PASS. 


\section{An Abandoned Attempt}

lations with each other. They command the respect of even our fighting hunter (the character given to Cherapanoff by his enemies). It is surprising how much the Russians think of these Kalmucks. They are so modest and unassuming that your best feelings go out towards them. They are so simple and lovable that it would be only the basest of men who would take advantage of them. They are born horsemen and hunters, and, although the Russian Government will not allow them to serve as soldiers, they excel the Cossacks in many respects ; they are respectful, brave and chivalrous. They wear a skin cap on their small round heads and a coat of bear or sheepskin tied round the middle; and their boyish faces and high cheek-bones are eloquent of vigour and strength. The Kalmucks wear the same skin coat all the year round. They evidently think that what will keep out the cold of winter will keep out the heat of the Siberian summer, which goes to the extreme of heat. If a man's happiness depends upon the fewness of his wants, the Akkem Kalmuck must be the happiest man alive, especially if what he has is the result of his wanting. I was delighted to be able to distribute some slabs of chocolate amongst the children, who had collected in the hut to welcome the mysterious white strangers. 


\section{My Climbing Adventures}

Two of the Kalmucks had come ro miles to see us. They had never heard of Moscow, St Petersburg or any towns in Europe; Biysk was the furthest any of their friends had been known to travel. The hut seemed a palace to sleep in after the cold nights sleeping in the open I tried to draw the inflammation out of my eyes by the fire, but without success.

We started early the following morning, as we wished to reach Katunda as soon as possible. Before we went, I sold the rifle which I had brought from Biysk to one of the Kalmucks who had followed us to the mountains. $\mathrm{He}$ and another Kalmuck had quite the monopoly of the shooting over the Akkem valley. Halfway up the pass we met two Kalmucks on the way to visit us. They were fine specimens of horsemen, and were mounted on small sturdy ponies. In the course of conversation we learnt that they had run short of food, because of the severe and prolonged winter. This was the reason we could not get any good bread, and only a few dry rusks. Judging by the experience Professor Sapozhnikoff had in the summer, and my own experience in the winter, the weather must be very changeable. Sudden blizzards and fierce north winds, with blinding snowstorms, occur in the winter; and excessive rains and dust162 


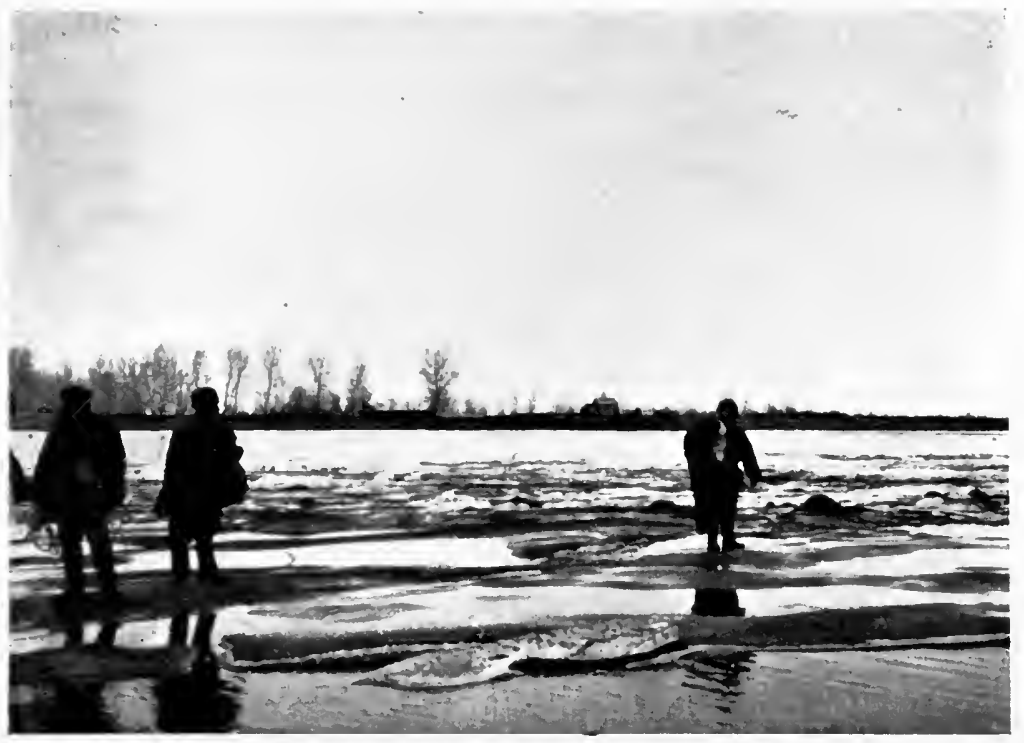

AUTHOR'S PARTY ON RIVER BIYSK BROKEN ICE. A FAST FLOWING DANGEROLS SIBERIAN RIVER.

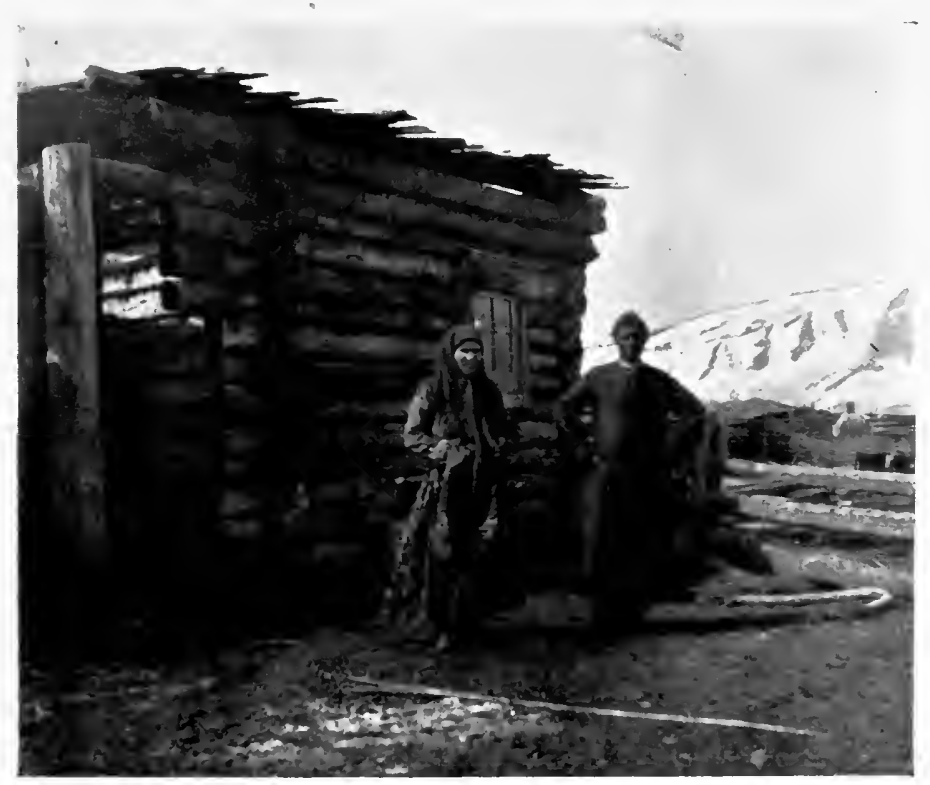

MY HUNTER, HIS WIFE ANI MANSION. 



\section{An Abandoned Attempt}

or soil-storms in the summer. The very heavy rains are usually in May and June.

Once over the summit of the pass we descended through a forest and came to the River Katun, which was in most parts free of ice.

A Kalmuck hunter rowed us across in his dugout. We soon reached Katunda, and after staying one night, commenced the journey of 800 miles to the railway line.

The incidents of this return journey were both exciting and numerous. None of the peasants knew their way, and we were stuck in swamps time after time. In fact we had all conditions of weather and ground to cover.

One moujik excused himself for losing us because of the spring thaw having covered the track with water; another moujik excused himself because of fresh-fallen snow; and one said he knew the road very well when the moon was out, but on a dark night he had no idea of the way the road went. To crown all, one moujik actually excused himself because his horses had never been that way before. Despite getting lost on nearly every stage, the moujik always said before starting that he knew the route.

We crossed the River Bye as the ice was I63 


\section{My Climbing Adventures}

breaking up. One of the moujiks who was carrying a bag over the ice went to sleep on the ice with his head on the bag. The block of ice on which he lay was quite loose and might have moved down the river at any moment.

Nothing special occurred, and we reached Novo-Nicolaëvsk and crossed the river just before the river ice began its journey into the Arctic. I joined the train for Moscow, and during the journey I had plenty of time to reflect upon the Altai trip.

There is a great deal to be learnt in regard to the mountain districts of Siberia. My own theory of their formation is that the earth's pressure must have pushed them up at no distant date. The rocks are quite new and soft, yet the edges have not been worn smooth. Notwithstanding their softness, moreover, there is very little crumbling. Of the great mountains in the world, the Himalayas form the largest semicircle. The ends of the ranges point north, and the range bends like a bow to the south. The Himalayas and the Caucasus form a semicircle, which stretches across a large portion of our earth's surface.

The ranges of the Altau and Altai are branches I64 


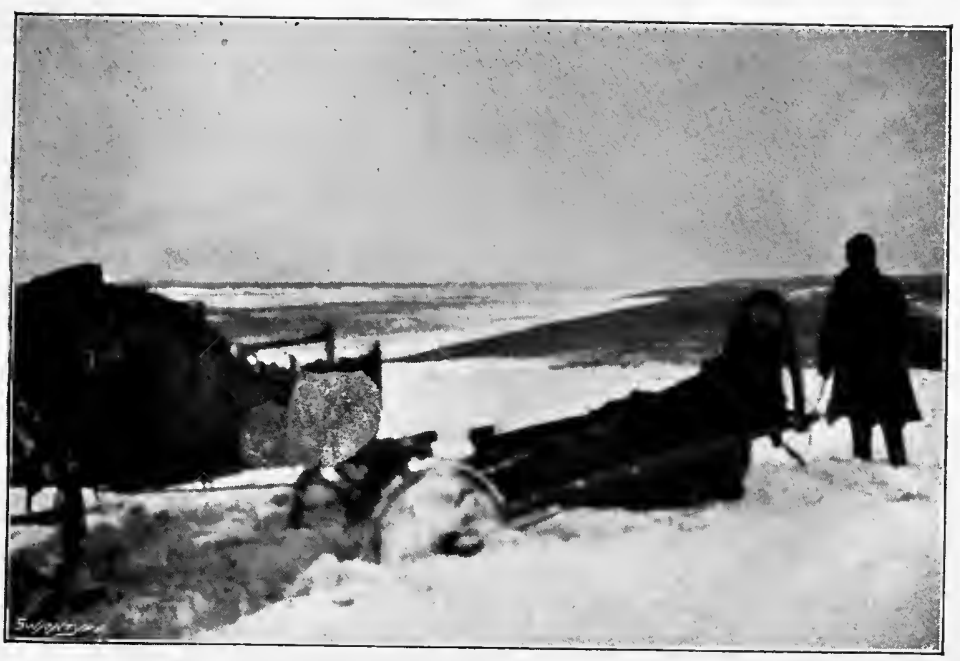

THE PLEASURES OF A THAW.

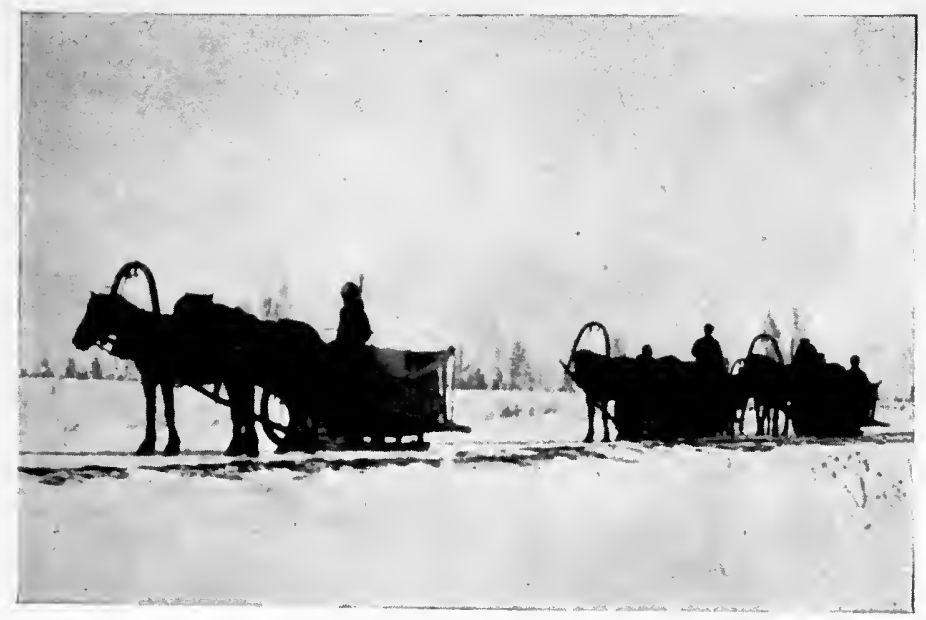

THE ONLY SLEDGES WE MET FOR 400 MILES. 



\section{An Abandoned Attempt}

of the Thian-Shan, which joins the Himalayas. The same semicircle structure is still more apparent in the Katunskië-Belki range. In the Akkem valley, and by the side of the Akkem Glacier, there are four or five mountains of rock similar in shape to the séracs of the Glacier de Géant. The Siberian mountains become smaller and smaller as you journey towards the Arctic, and when I was at Tomsk, the capital of Siberia, I saw where the commencement of the system of mountains were at that part only very small hills. If the earth's mountains are formed by pressure this is as it should be. Mount Everest, which is the highest, has been pushed up highest, because the rock gave the greatest resistance, but it forms the arch on the bow-shaped ranges of the Himalayas and the east and west of the great main range project in a northerly direction. The theory that mountains are formed by the earth's pressure has been proved clearly to my mind by my visit to these previously unknown mountains.

The fauna and flora of the Altai are very varied, and their examination would repay tenfold any one who would take this trip to the mountain district.

The Royal Horticultural Society says the Altai 165 


\section{My Climbing Adventures}

is the natural home of some of the most beautiful of our cultivated plants.

The fact that 50,000 tons of honey and 150 tons of bees'-wax are exported from this country annually shows what a wonderful country it is. A chapter on the Altai flora was published in my book, Siberian Travel, Exploration and Climbing, but nothing had previously been printed on the subject in the English language.

Space will not allow me to give would-be explorers of Siberian mountains any hints as to equipment, but I should be very happy to afford any one the necessary assistance if he or they will write to me. The exploration of the Siberian mountains was one of my most happy and risky adventures. The extremely cold and pure air made me feel in perfect condition; very little sleep was required, and I found that we could travel for eighteen hours a day and keep quite fresh and fit. It is better air in the Siberian mountains than in the Swiss Alps or any Alps I have visited. I believe that the air of the high Siberian Alps, with its intense, pure and invigorating cold, would purify man's system of almost any disease. 


\section{CHAPTER IX}

CUMBERLAND CLIMBING-DISCUSSION OF THE FACULTY THAT MAKES A CLIMBER

FTER my experience in Siberia, during the
climbing of one or two difficult pieces of rock, I made up my mind to have more detailed rock-climbing; and accepted a friend's invitation to climb in the Cumberland mountains.

That Easter of 1904 my friends and I found extra difficulties in ice-glazed rocks, which prevented most climbers from climbing. The following is a cutting from the Daily Mail, Thursday, 7th April 1904 :-

\section{Climbing in Cumberland}

Difficulties of Mountaineering in England

A number of climbers, who have hitherto confined themselves to the Swiss Alps, were attracted to the Wastwater district of Cumberland during Easter, and they have returned much impressed by the difficulties which these rocks present even to experienced Alpinists.

"There was next to no rock-climbing," said Mr S. 167 


\section{My Climbing Adventures}

Turner, the well-known Alpinist, who was one of a party of three, "but there was plenty of snow-work, and I was astonished at the quantity of ice and snow, and at the mists and storms we encountered.

"Our first expedition was across the scree to the Great Chimney, which is a moderate climb in summer. But we found all the hand-holes and foot-holes iceglazed and covered with snow, and the wind tried its best to blow us off the Great Gable.

"We found the rocks of the Arête altogether hopeless, so we tackled the famous Napes Needle, an interesting bit of climbing in a gale of snow and hail.

"The next morning saw us at the Pillar Rock, to see if it 'would go,' in mountaineering phraseology.

"The scene was Alpine in a remarkable degree.

"Half an hour of snow-slopes brought us to the north face of the rock, and then we roped.

"It only required fifteen minutes of climbing to convince me that the English climbers have to be made of the genuine stuff.

"I found the ice-glazed, snow-covered rocks very cold without gloves; and many of the chimneys and cracks were glazed. We crawled, wriggled, wormed and twisted up to the cracks, chimneys and fissures, until we came to the Stomach Traverse, which we found to be the easiest bit of the whole climb. A zigzag course brought us to the famous 'Nose,' a rock sticking out over space.

"On a fine summer's day this climb would be easily 'beaten,' but the drifting snow and the blizzard made it formidable.

"Once on the top of the Nose we were greeted with such a blinding hailstorm and the mist was so dense that we could see nothing. 


\section{Cumberland Climbing}

"This mist made us lose our way, and we wandered down a sloppy, marshy valley towards Ennerdale, and finally found a farmhouse, where we got warmth and refreshment.

"We felt somewhat humiliated, as no one had ever heard of experienced climbers being lost on the Pillar Mountain.

"As a matter of fact, our not returning to the Wastdale Head Hotel had convinced the people there that something had occurred, and a search party of fourteen set out with lanterns and stretchers for the Pillar Mountain.

"We met them on the way, and hailed them with mixed feelings.

"They made our leader carry a stretcher back as a punishment for losing the way.

"One of the rescuers remarked, 'it was a bad place to have an accident, as the carrying down would be very difficult.'

"That Cumberland climbs are dangerous we proved again next day, when we treated the Mickledore Pass with care, because of the ice under the snow.

"Half-way down we found a tourist who was stuck. We hitched him on our rope. He had no nails on his boots, and informed us that he was afraid to go down, as a friend had preceded him at an enormous speed.

"It would have been the easiest thing imaginable for him to have glissaded quickly, overturned, and broken his neck, which happened to a young man in September last.

"A good climber takes no unnecessary risks and when we tried Central Gully, Great End, and it took me over an hour getting ro yards across an ice wall, my friends decided that they could not hold me if I slipped. Therefore we had the courage to turn back. I am certain 169 


\section{My Climbing Adventures}

' that the Cumberland climbs will increasingly attract the sound in mind, body and limb."

The ice and snow climbs are not always to be had in the crags, but what would be considered impossible in the Swiss Alps is attempted and often climbed when they do get snow and ice in Cumberland; just in the same way as rock-climbs in Cumberland (that is, the first-class climbs) are very much more difficult than most of the noted difficult climbs in Switzerland. The only reason why rock of the same degree of difficulty is very rarely climbed in Switzerland is because the Swiss climbs are four or five times longer, and the rarity of the air has to be reckoned with. There is also something in the depth of the chasm or precipice underneath the climber which has some effect. Anything over too feet of a sheer drop will be just as fatal as 1000 feet or even 5000 feet; but instinct makes the average climber very much more cautious if he sees a clear drop of 5000 feet beneath him while he is climbing. It is difficult to understand why this is so ; and to some of the expert and most soulinspired mountaineers it never really makes any difference. As a matter of fact, the expert climber cannot be any more exacting and cautious at 5000 feet than he is with a 25 -feet drop beneath him; he I70 


\section{Cumberland Climbing}

would never climb long enough to become expert unless he was desperately accurate.

This characteristic becomes so pronounced in the expert climber that he often finds himself walking downstairs in the most careful and deliberate manner; and even while climbing a harmless piece of rock or snow he does it without any semblance of carelessness. My friend Binns of Sunderland made a slip or two while I climbed with him in the Alps, and he argued that every climber should know how to slip and save himself. I argued that the habit of taking the slightest chance, or of risking a slip, because he had the confidence of being able to save himself, would in time produce that characteristic of carelessness which would probably prove fatal.

I have read time after time that amongst the expert climbers fatalities are rare, but I don't accept that statement as correct. It is very human to become over-confident in climbing, like it is at other games of skill, such as boxing, fencing, golf, etc.; and over-confidence produces the slip on the mountain and its penalty, as at other skilful pursuits.

The over-confident climber, however expert he is considered to be, reduces himself to the novice's risks of "the fatal slip," as soon as that confidence 


\section{My Climbing Adventures}

becomes characteristic. Nobody that I have ever climbed with has had to complain of my loosening stones whilst leading, or of making a slip that could be prevented by careful movement : but I have had to complain to my climbing companions about overconfidence and loosening stones. On the other hand, I have been accused by New Zealand climbing companions of taking undue risks by continuing a climb during severe storms; this brings me to another of the causes of fatal accidents, and probably the most serious, judging by the fact that eleven men lost their lives directly owing to a severe storm on Mont Blanc, and were found frozen to death on the gradual slope near the summit. A climber to a great extent can tell if he can stand the storm or not, according to his bodily condition and what he has gone through in that way before. For instance, I travelled I600 miles in Siberia, and climbed in the Siberian Alps in winter, encountering snowstorms and such severe cold that the cold and storms on the New Zealand Alps did not affect me. On the other hand, my climbing companions felt the storm and cold very much, because they had not been used to anything more severe. In addition to this there is a question of the nature of the glaciers or snow-slopes, over 


\section{Cumberland Climbing}

which one is travelling. If it is very much crevassed or a puzzling route, it would be madness to continue in a storm : but in our case, the glacier and route were very easy, even through the most serious storm, because the slope was so gradual and protected that the terrific wind-storm which sometimes visits the New Zealand Alps-which is furious enough to blow the climber off an exposed ridge-could not affect me on the Mount Sealey ice-slope, which was one of the climbs that raised the question. 

BOOK III 



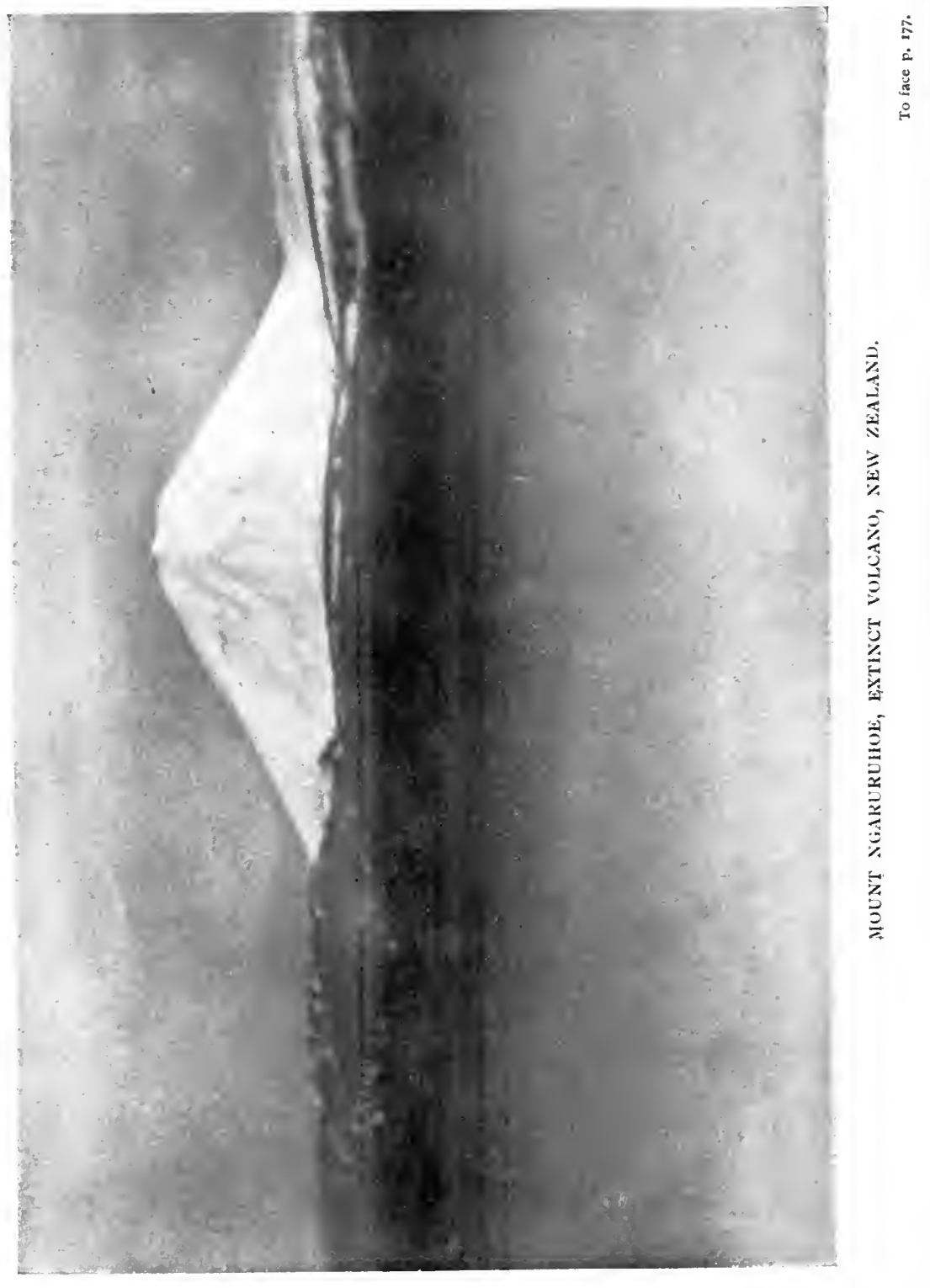




\section{CHAPTER X}

FIRST WINTER ASCENT OF MOUNT NGARURUHOE AND FIRST CLIMB OF PRIEST'S CAP

G ARLY in the spring of 1905 , just after I 1 had planned a business trip to New Zealand, I was introduced to $\mathrm{Mr}$ Donne, Government Tourist Superintendent for New Zealand, who was on a visit to London. He said: "Why don't you come and climb some of our New Zealand Alps; you will find them very much more difficult than the Swiss Alps." I informed him that I should be pleased to try conclusions with them, if he could find me companions. The arrangements were made between $\mathrm{Mr}$ Donne and myself that I should be the guest of the Government, and that I should take $\mathrm{Mr}$ Clarke, the Government guide, and have all the equipment I required, on condition that I wrote and lectured about the mountains after I had climbed. I finished my business in October, and as it was too early to go to Mount Cook district, Mr Donne suggested that I should visit the thermal system 


\section{My Climbing Adventures}

round Rotorua and come down the middle of the North Island, and climb the active volcano Ngaruruhoe. He gave me a letter of introduction to Mr Danby Ryan of Lake Taupo, who was to act as my guide. This gentleman thought the condition of the mountain and the weather much too dangerous and would not climb. He gave me a letter to a Tokaanu policeman, $\mathrm{Mr}$ Sweeney. He refused to go, but knew a Maori who had climbed it in the summer. The Maori also thought it too dangerous. The storekeeper at Tokaanu volunteered to accompany me, but I afterwards came to the conclusion he had his eye on the prospects of my buying my tinned provisions, etc. from him. After resting a night at Tokaanu, the storeman suggested I should go on the coach early the following morning and he would follow. I started by the coach but he did not keep his word. On the way to the half-way hut between Tokaanu and Waiouru the road-mender got on the coach and became curious to know how I was going to climb by myself. As it turned out, however, I convinced him that it was the correct thing to do, and when we reached the road-hut he had decided to climb with me. The prospects of plenty of provisions allured him on. 


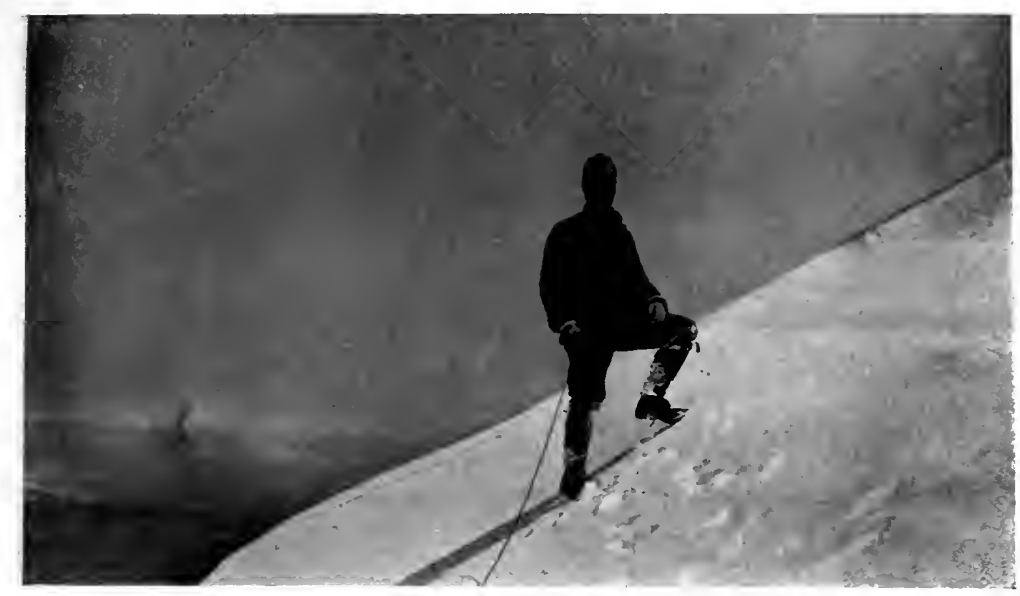

AUTHOR ON HARD FROZEN SLOPES OF MOUNT NGARLRLHOE PHOTOGRAPHS HIMSELF BY LONG TEBE.

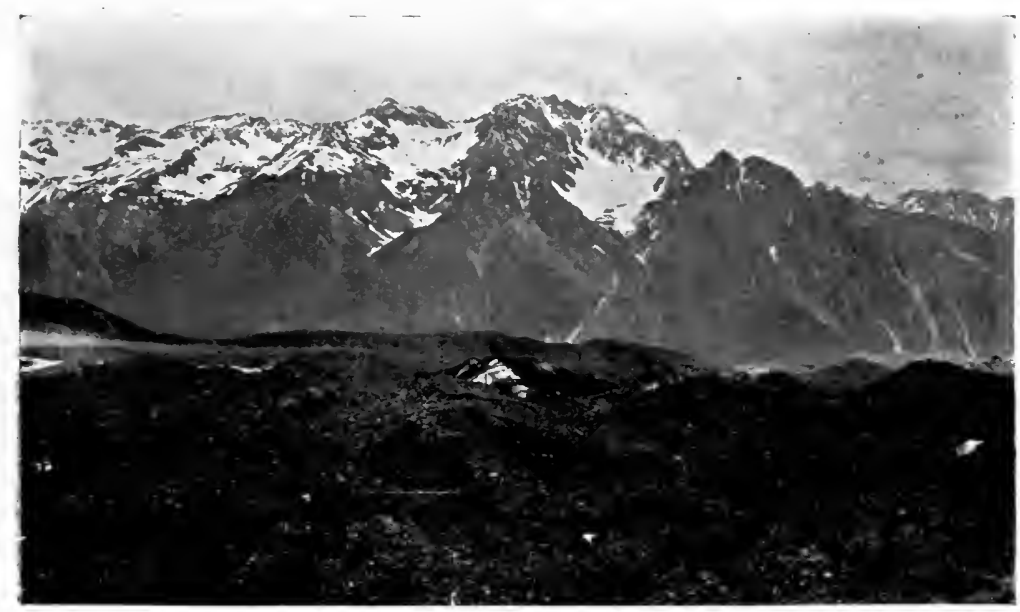

LIEBIG RANGE FROM TASMAN GLACIER. 


\section{Winter Climbing in New Zealand}

We started across rough country through streams, and after about one hour's walking arrived at the mountain hut. We made ourselves as comfortable as possible, but the hut had no chimney in it and the smoke had to go out of the door. We had brought a Maori boy with us, and when we awoke at four o'clock the following morning and found it snowing he lay awake to arouse us as soon as the snow stopped.

The winter ascent of Ngaruruhoe had never been accomplished before, and I was not sure that I should ever be in New Zealand again. This, together with the persistent refusals of the different men around Lake Taupo to climb with me, was the sort of thing that makes a climb worth doing.

The Wellington Press from The Evening Post, 18th October 1905, will explain the incident fairly well, as follows :-

First Winter Ascent of Ngaruruhoe

Thrilling Experience of an English Mountaineer A Night in a Blizzard

Mr Turner has come to New Zealand on business, but he is taking a holiday for climbing while here. His first 


\section{My Climbing Adventures}

experience, however, has been of a somewhat unusual and thrilling nature. $\mathrm{Mr}$ Turner left Wellington the other day for Auckland and Rotorua, intending to return overland to Wellington, and make a winter ascent of the volcano of Ngaruruhoe en route. I gave $\mathrm{Mr}$ Turner what advice I could about the ascent of Ngaruruhoe and Ruapehu, and heard no more of him till a telephone message this morning summoned me to a private hospital, where I found the adventurous explorer lying in bed in a darkened room, suffering from snow-blindness. He was reluctant to be interviewed, but eventually I persuaded him to tell me his story. After witnessing the wonders of the Rotorua district, which greatly impressed him, Mr Turner crossed Lake Taupo and made his preparation for the climb in the little village of Tokaanu.

He failed to obtain a guide, but determined, nevertheless, that he would make the first winter ascent of the volcano.

Accordingly he produced provisions and left in the coach for the half-way hut. On the journey to the hut a roadman joined the coach, and $\mathrm{Mr}$ Turner interested him in the climb, and eventually persuaded him to accompany him. He also persuaded a Maori boy to come with him as far as the mountain hut. It snowed all night, and the trio spent rather an uncomfortable night in the hut, which is minus a chimney. In the morning it cleared, and $\mathrm{Mr}$ Turner obtained his first view of the snow-clad slopes of the volcano cone. The hut is not in a good position, and there is a considerable tramp before the actual climb can be commenced.

Mr Turner, with the roadman, skirted the foot of the mountain for a considerable distance, in order to find an easy ridge, but not finding one, decided to ascend by way I 80 


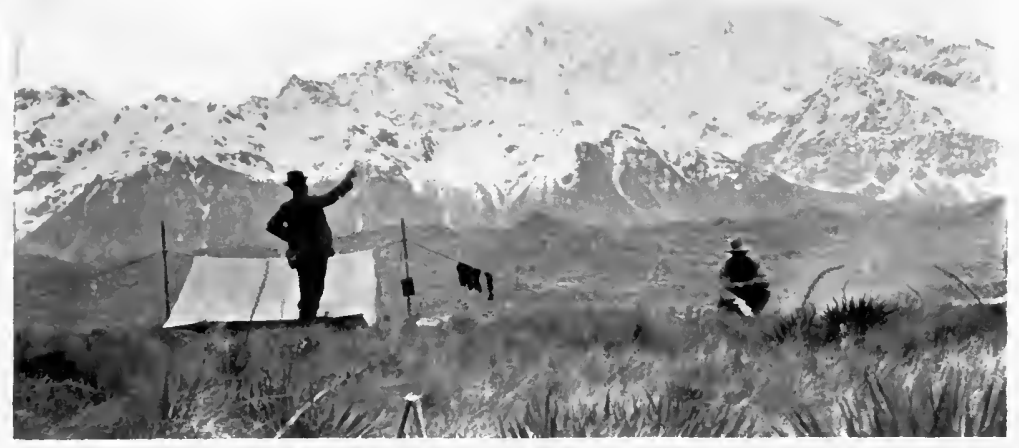

BASE CAMP FOR PRIEST'S CAP CLIMB.

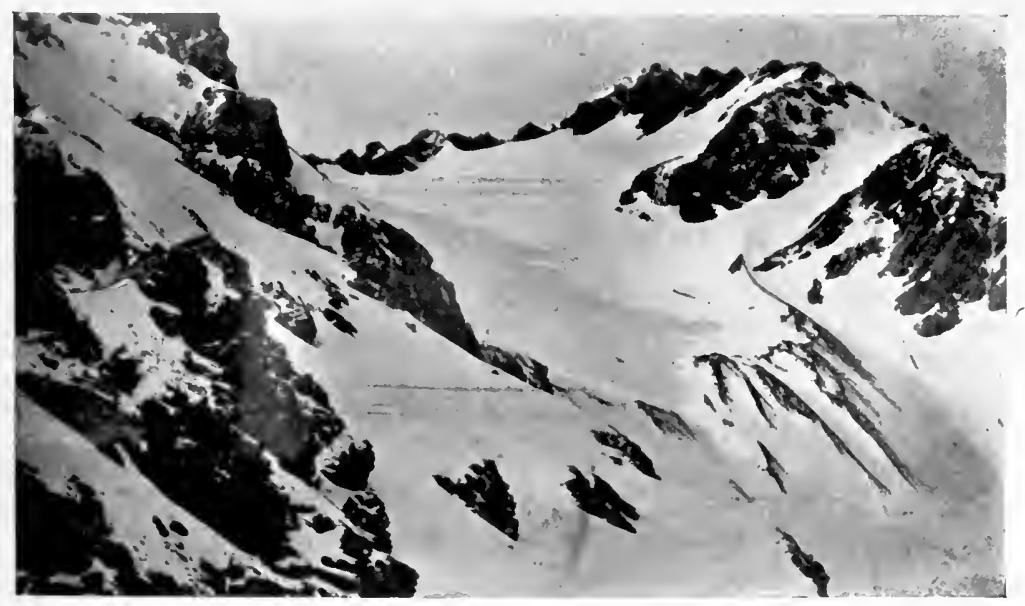

SUMMIT SNOW SLOPES OF PRIEST'S CAP MOUNTAIN, NEW ZEALAND ALPS. 


\section{Winter Climbing in New Zealand}

of the snow slopes. It is an axiom in mountaineering that an easy climb can be converted into a difficult and even a dangerous one by severe weather conditions, and this is what happened in this instance.

After climbing some little distance the roadman slipped and came sliding down the slope, but was saved by Mr Turner after he had slid about 18 feet. This was enough for the roadman, and $\mathrm{Mr}$ Turner asked him to remain where he was while he made the ascent alone. The mountain was in very bad condition, and in one place there was three hours' step-cutting to be done in hard ice. Climbing in a spiral route, however, $\mathrm{Mr}$ Turner reached the summit of the mountain in safety, and took a number of photographs. A strong wind had risen, and while he was photographing the crater, his hat with his indispensable snow-goggles attached, was blown away down the mountain slopes. The fumes from the crater and the driving powdery snow gave him a bad time, and the almost blinding glare had the inevitable result of affecting his eyes. Under these circumstances the descent was a trying one, but it was accomplished in safety, and the foot of the snow-slopes was reached at 4 P.M.

By this time the roadman had taken his departure, and Mr Turner began to battle his way back across long, dreary wastes of snow to the mountain hut.

The snow which was frozen in the morning and had been easy walking was now softened by the sun, and it was a case of sinking up to the hip at nearly every step. Under these trying circumstances an easier route was sought, but it was found impossible to get back before nightfall. Tired and hungry and partially blinded by the snow-glare and drift, the intrepid climber continued his journey in search of the little mountain hut; but he tried 


\section{My Climbing Adventures}

one way and the other without success. Midnight found a blizzard raging, but still he struggled on. Two or three times he stumbled exhausted, and about four o'clock he was nearly delirious with the pain of his eyes and the constant strain and fatigue.

He climbed to the top of a small hill, and finding there a small cave about 15 feet in circumference and 3 feet high, he crawled into it, took off his boots, wrung the water out of his socks, and putting his feet into them and then into his knapsack, he lay down to sleep. He dozed for about an hour, and then woke up shivering, just as day was beginning to dawn beyond the wooded slopes of the Kaimanawa ranges. He witnessed a glorious sunrise, and then knew he was safe, as he could see the road-hut or the direction of the hut on the road. He had steered by the aid of the compass after giving up all hope of finding the secluded mountain hut, and his compass bearings had been taken correctly, so he made direct for the road-hut. At about three o'clock on Sunday afternoon he reached his destination. With the exception of one or two short spells and the hour in the cave, he had been on the go for thirty-three hours without food, save for half-a-dozen biscuits that he had taken with him on leaving the mountain hut on Saturday morning. There can be no doubt that his indomitable pluck and endurance pulled him through. For the next few days he suffered terribly from snow-blindness. The journey from IVaiouru to Taihape had to be made on horseback. $\mathrm{He}$ reached Wellington, and on consulting Dr Garcia Webster, the leading eye specialist, was ordered into a private hospital. Mr Turner is already convalescent, and hopes to be up and about by Monday next. One would have thought that he had had enough of mountaineering for the I 82 


\section{Winter Climbing in New Zealand}

time being, but he is already planning an expedition to climb Mount Cook.

This is a brief account of this particular expedition. There is no doubt about my being absolutely blind, with the lids of my eyes only able to open for a second at a time during my climbing. The drift-snow in the moonlight allured me down valley after valley in the hope that it was smoke from the fire at the mountain hut, which I made sure would be lit by the roadman to attract my attention. I afterwards learnt that, instead of this man lighting a fire or waiting for me at all, he hurried down to the road-hut and said he would claim my bag and equipment if I did not get back again, as he was sure I would be lost on the mountain.

One month after leaving the hospital I was climbing the Mount Cook district, and two months from that date I did the longest and most dangerous traverse practicable to any mountaineer, viz., the first traverse of Mount Cook. I will deal with my climbs in the Mount Cook district in their order as they occurred.

If you are ever fortunate enough to stand at the door of the Ball Hut on the great Tasman moraine, you will be able to look across the huge 


\section{My Climbing Adventures}

hills of moraine in the direction of E.S.E. to S.E. Your view on a clear day will embrace the highest Aiguilles of the Liebig range, which are to be seen from the Tasman side.

The particular attraction about this part of the range, as Messrs Ross, Fyfe and myself started for the climb of it (the day before Christmas Day) was that every peak on that range was a virgin peak-no foot of man had stood on any summit of that range. While on our way to climb Mount Sealey a few days before, Fyfe and I had seen Nun's Veil, the highest peak on the Liebig range. We picked our way across the glacier, which, judging by the continuous falls of stones, is very active. An occasional kea alighted to inspect us closely. Once over the moraine we had an easy descent round the foot of the Malte Brun range, of about 700 feet, to the level of the Murchison valley; we rounded the Tasman moraine, which intrudes on this valley. The Murchison River proved much easier than we expected, as it had formed into twelve small streams, spread over a bed about $\mathrm{I} \frac{1}{2}$ miles across. We walked through it with little difficulty, and selected a spot to camp which was near a waterfall. After pitching the tent, and while dinner was being made ready, 184 


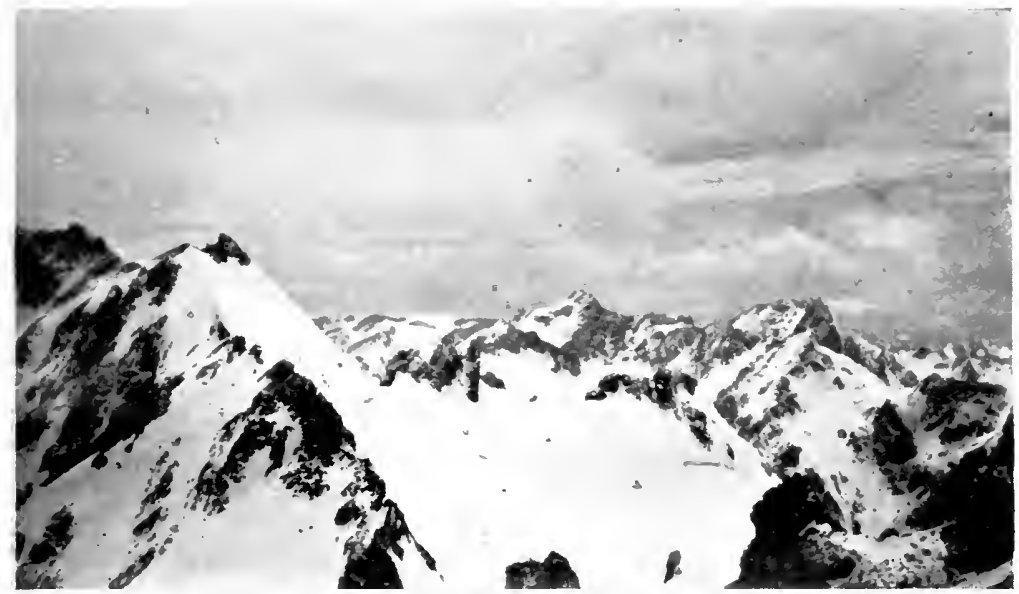

SCMMITS OF THE LIEBIG RANGE FROM THE SCMMIT OF PRIEST'S CAP.

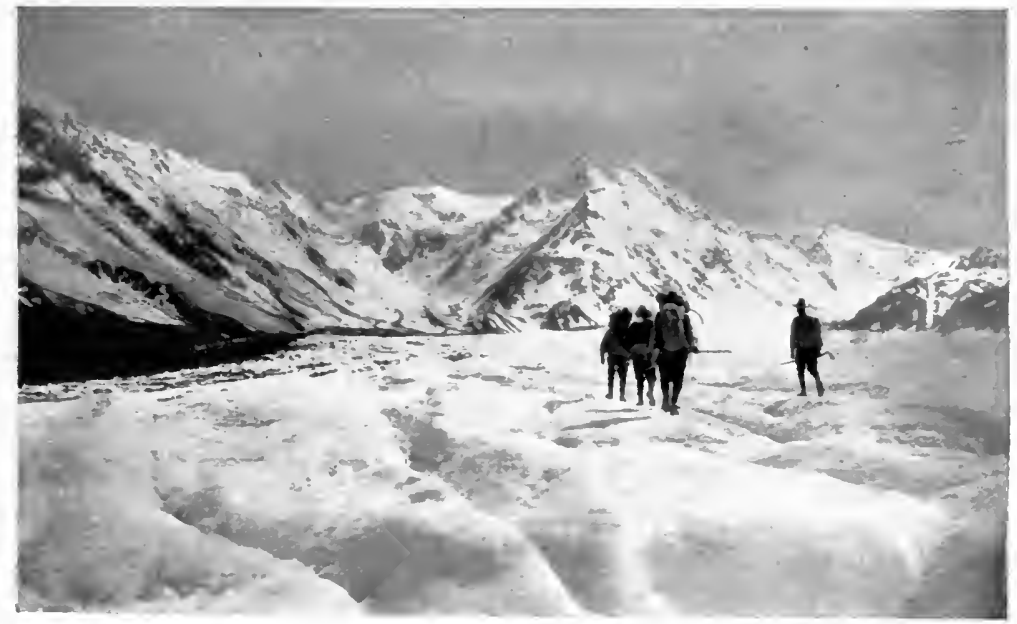

ACTHOR'S PARTY ON THE MARCH T"P THE TASMAN GLACIER. (Notice the heavy loads on the backs. We did our own portering.) 
• 


\section{Winter Climbing in New Zealand}

Fyfe and I climbed up a gorge under a huge waterfall, which looked beautiful in the sunset. There were four breaks in the waterfall, which is altogether about 1600 feet in height, and as they are not named I christened them "Proud" Falls. We washed in the clear water of its stream, and had a good drink of pure water.

We enjoyed dinner at that camp and soon turned in for the night, but as the first night in camp is always a restless one, we could not sleep. We intended to commence to climb with the dawn. At 1.30 A.M. I crawled out of the tent and surprised my Colonial Alpine friends by showing them that a "new chum" could light the fire and boil the billy under ten minutes. We struck tent, and at three o'clock commenced the climb up a steep. scrub-covered ridge, with the waterfall on our right. We had decided on the route to be taken the day before. It was my first scramble through New Zealand Alpine shrubbery, and as we travelled at a good speed in the dark, I seemed to have spear-grass running into my legs and arms all the time. It is no wonder we climbed rooo feet in about forty minutes. The speargrass was so sharp that it soon made us fully

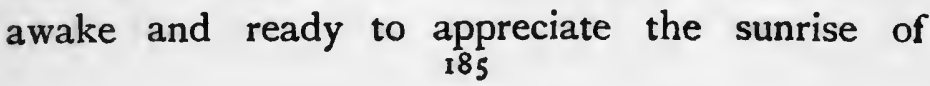




\section{My Climbing Adventures}

Mount Cook. The steel-grey shadows and first signs of dawn streaked over the peaks, shooting up into the heavens; other streaks met them, until the stars seemed to gradually fade, and a steel-grey coldness rested on the monarch of the Southern Alps, making that peak look twice its distance from us. The shadow soon changed into a silver tint. The top of Mount Cook appeared to draw nearer as the morning tint changed into pale gold and amber. All at once the precipitous sides of Mount Cook looked on fire, changing into a dazzling blaze of sunlight, drawing the slopes apparently nearer, and making the mysterious snow-capped summit look as though it were plunging over the precipice. The Tasman, Silberhorn, Lendenfeldt, Haast, and other peaks were lit up in the order named. The Liebig and Malte Brun ranges were now alight, and the dark shadows were fast fading away from their slopes. The whole mountain district was awake, and with its awakening the avalanches which had been silenced by the night frost soon developed into their loudest roars of freedom.

After this exquisite sunrise we had to turn our attention to rock-climbing, at first over long 


\section{Winter Climbing in New Zealand}

slabs of rock, but afterwards it became more interesting. The outward dip of most of them was very awkward for me, because I was wearing a pair of boots too old for a climb like this, and all the inside nails had come out. These were the very nails I required for this climb; so I had to use my hands to do many of the slanting slabs, and pulled myself across by my arm instead of using my feet to support myself. This made my climbing slower. We turned to the crest of the rocky ridge, and gained one of the high pinnacles, a snow arête dividing this pinnacle from the highest rock on this ridge. We rested to take a photograph or two. The view to the north was very rugged, quite a sea of peaks. From here we had three routes to select from: one was down steep snow slopes ending in a precipice, the other to cross the small arête and climb the remaining rocks on the ridge, while the third (and, to my mind, the easiest) route was to descend a snow couloir and up the centre of a snow slope. After two hours' steady plodding we neared the top of the slopes, where there were two huge towers of rock. We climbed up the edge of some very steep snow round to the back of one of these rock towers, and gained a ridge which practically 


\section{My Climbing Adventures}

divides the Murchison valley and another valley which we could not recognise. We then proceeded to the right across a short, knife-like edge, where we could see down the precipices of the Priest's Cap and Nun's Veil. A huge bergschrund was in the middle of the glacier. We could see that the Nun's Veil, which we had decided to climb, could not be climbed without going over the Priest's Cap.

After enjoying a little lunch behind a clump of rocks, trying to shelter from the cold wind, we did not stay long. Then climbing over some very loose rocks on a sharp rock arête, only one moving at a time, we gained the last slopes and were soon climbing up the final slopes, and stood on one peak. After crossing a snow ridge we walked up to the highest peak of the Cap. We stood on the summit of Priest's Cap at I I o'clock on Christmas morning, when thousands of people would be just going to church. The mountains have a refining influence, but what could be nearer holy thoughts than a "Priest's Cap," which was the name that had been given to the peak on which we were standing, owing to its resemblance to a priest's cap when seen from the Tasman valley? 


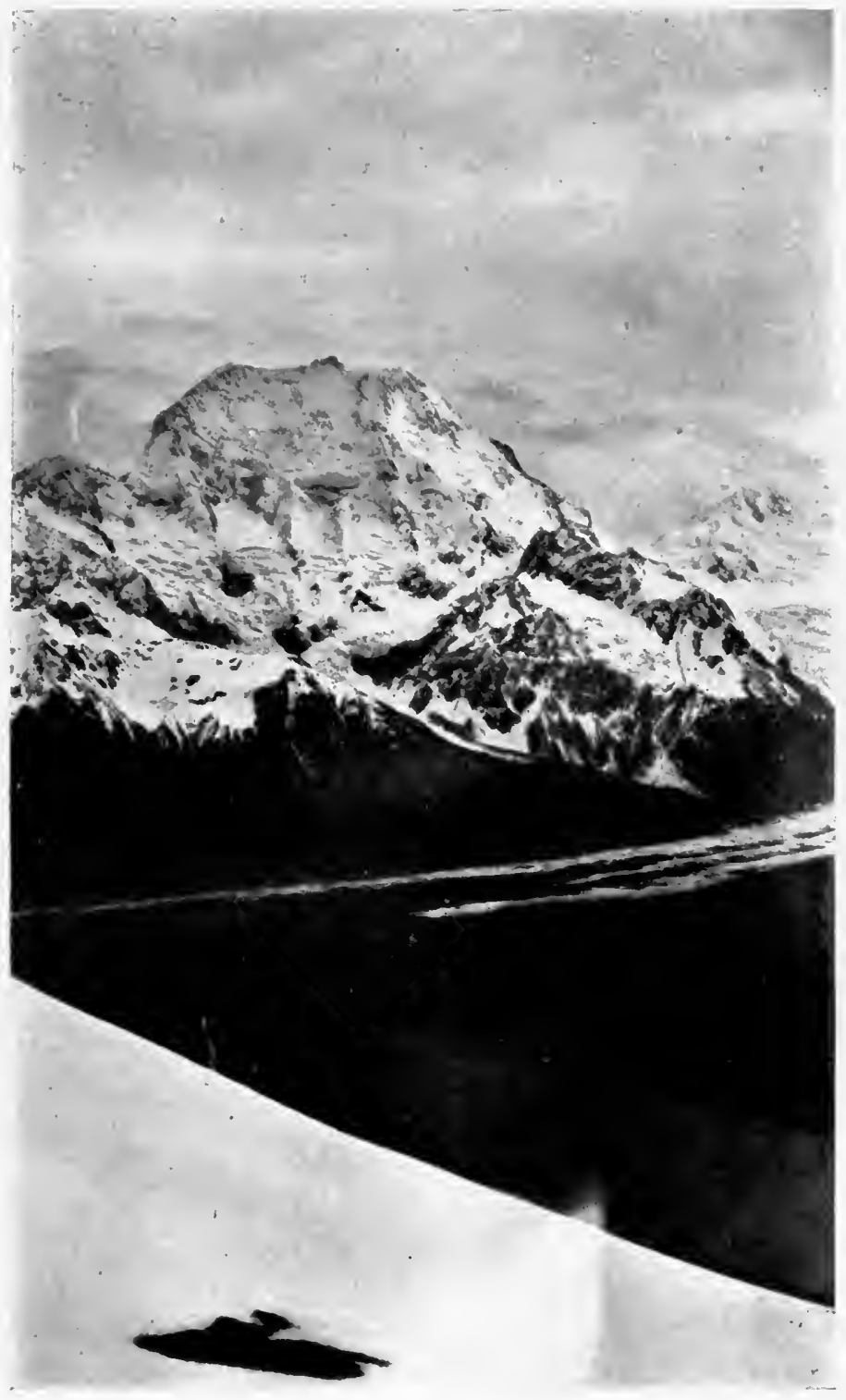

IO,OOO FEET OF MOUNT COOK FROM SUMMIT (IF PRIEST'S CAP LOOKING ACROSS THE TASMAN VALLEY. 



\section{Winter Climbing in New Zealand}

We spent too much time climbing round the rosary ridge (off our route) to enable us to climb Nun's Veil, which would have meant climbing down a huge chasm and up a precipice on the opposite side: so we contented ourselves with this victory, it being the first time anybody had stood on the summit of any peak on the Liebig range. We made easy work of the descent by glissading.

I might have started the account of my New Zealand Southern Alp-climbing by the attempt on Mount Sealey. This attempt was made about three days after my arrival at the Hermitage, in company with $\mathrm{Mr} \mathrm{T}$. C. Fyfe, one of the pioneers to first scale the summit of Mount Cook. After going over numerous ridges and snow slopes we gained the final snow slope in the full force of very severe wind, which blew the snow off the mountain, almost blinding us. In addition to this, the snow up which we were trudging (and had been trudging for several hours) was very powdery and soft. As we reached the rocky pinnacle of Mount Sealey $\mathrm{Mr}$ Fyfe refused to go on, and would not wait until I went on and climbed the remaining 1000 feet of Monte Sealey to reach the summit. He said it was too dangerous, but I was very much annoyed with him for not 


\section{My Climbing Adventures}

agreeing to wait for me. I told him that I did not hold with a climber being too afraid of bad weather: and that unless he got used to climbing through a storm it might some day prove a serious matter if he was caught in a severe storm without having practised steering his party or himself by the bump of locality only. After my Siberian experience, going up Mount Sealey seemed to me quite safe and easy: but it was most exasperating when we had travelled all day to reach the summit, and only needed two hours to reach it, that my companion refused to go on!

On the other hand, I must say, in justice to $\mathrm{Mr}$ Fyfe, that most Alpine climbers would have decided that he had acted correctly in refusing to go on. This climbing in bad weather is a debatable point; the very bad and impossible conditions to one man are not very bad or impossible to another. It is a matter of confidence in the man himself, his fitness at the time, and many other conditions.

An Attempt on Mount Elie de Beaumont

The snowfall in the Southern Alps was the heaviest on record in December 1906, and on the Igo 


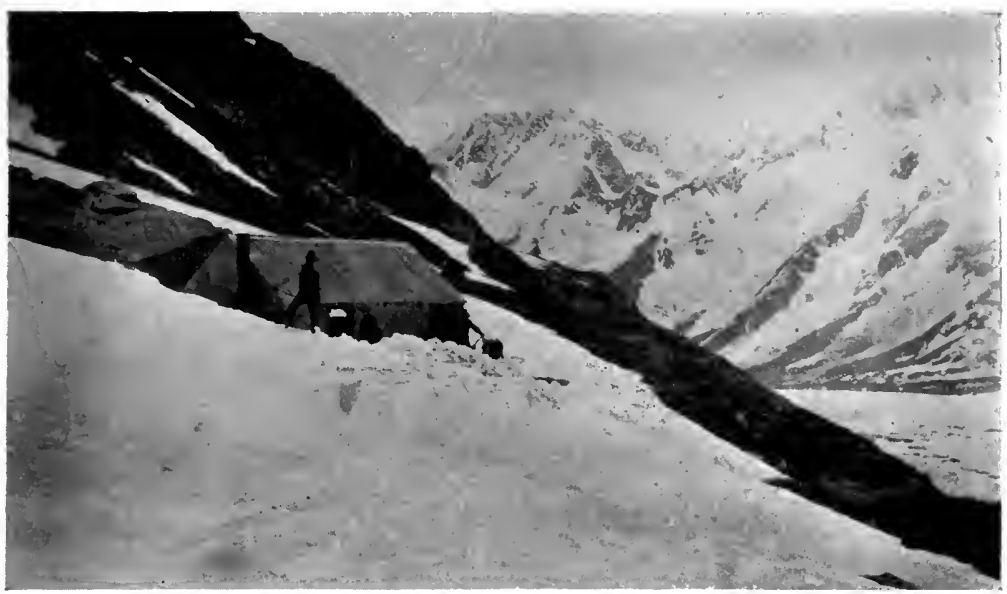

MALTE BRUN HUT.

(Author's party dig it out of the unusually deep snow, Tasman glacier.)

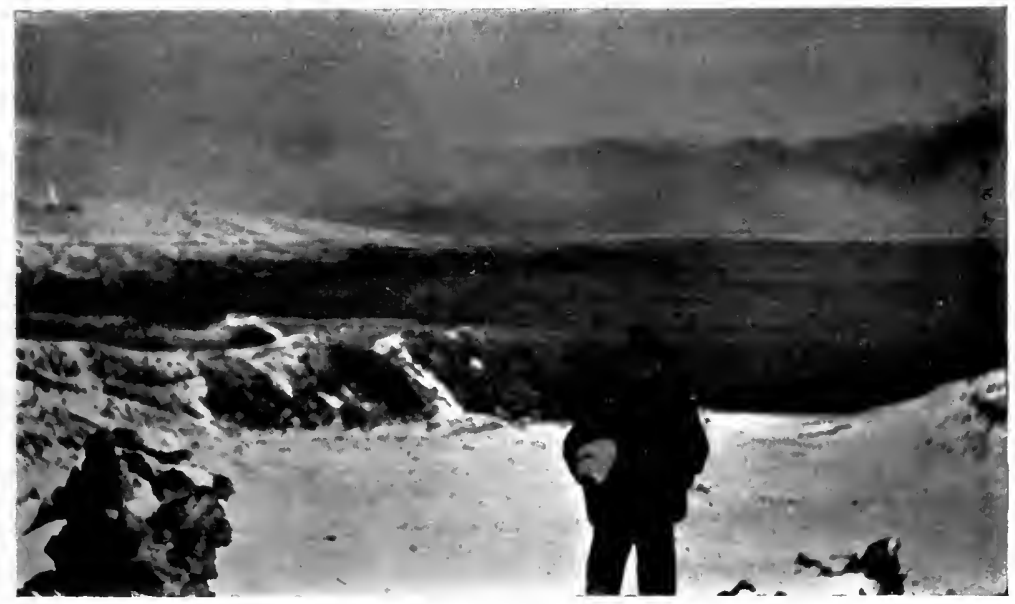

AUTHOR LENT A JERSEY TO THE ROADMAN ANU PHOTOGRALHED HIM AT THE SPOT ON NGARURUHOE WHERE HE PROMHSED TO WAIT. 


\section{Winter Climbing in New Zealand}

8th of that month the Malte Brun Hut on the Tasman glacier had to be dug out. A few days after that we arrived at the hut in the hope of climbing Mount Elie de Beaumont, but the snowstorm started again and kept us prisoners for a number of days. On the first reasonable day Mr Graham brought a party to the hut to make the ascent of the Dome. I had suggested, and it was practically agreed upon, to start at I2 o'clock midnight : but as the party were going to climb about 2.30 A.M., my companions decided to start with them at 2.30 A.M., much against my desire, as I thought I 2 o'clock plenty late enough.

For about 4 miles up the glacier the glacier snow was in splendid condition, and we walked quickly, helped by a strong cold wind. After two hours we put out the lantern and quickly ascended the slopes. Parting from our friends, they took a course to the right, and we turned sharp to the left, and up some steep slopes, evading one or two large crevasses. on our left. At the foot of the glacier we paused, and decided to take a route towards the left of the glacier, which was the only practical route. If there had been any other, we should have taken it in preference, because it looked dangerous, judging by the position of 


\section{My Climbing Adventures}

the overhanging serracs towering over the centre of the glacier and on the precipitous slopes of Mount Walter. We had about rooo feet of steep, soft snow, some parts of which was strewn with blocks of ice from the huge blocks which had tumbled quite recently. We had to climb up a groove caused by a recent avalanche, which had buried itself in a deep crevasse. After climbing the top of the steep groove up hard snow we came to a snow-bridge, over which we crossed a huge crevasse, coming to a second crevasse, which had no snow-bridge to cross. Stamping the snow down hard on the edge I made it secure for Ross and Fyfe to jump after me. This was necessary, because we had to jump up about 3 feet, and about 3 feet across, with a rucksack on the shoulder. I jumped and cleared the crevasse and made the rope tight, and Ross and Fyfe followed. We then worked to the right to evade some huge ice séracs, which might have toppled over at any moment. Fyfe had taken the lead after we cleared the crevasse, and we made for the centre between these séracs to be out of the line of fire in case one of them should break. Fyfe complained of the snow being too soft and steep in the centre. We sank up to the 

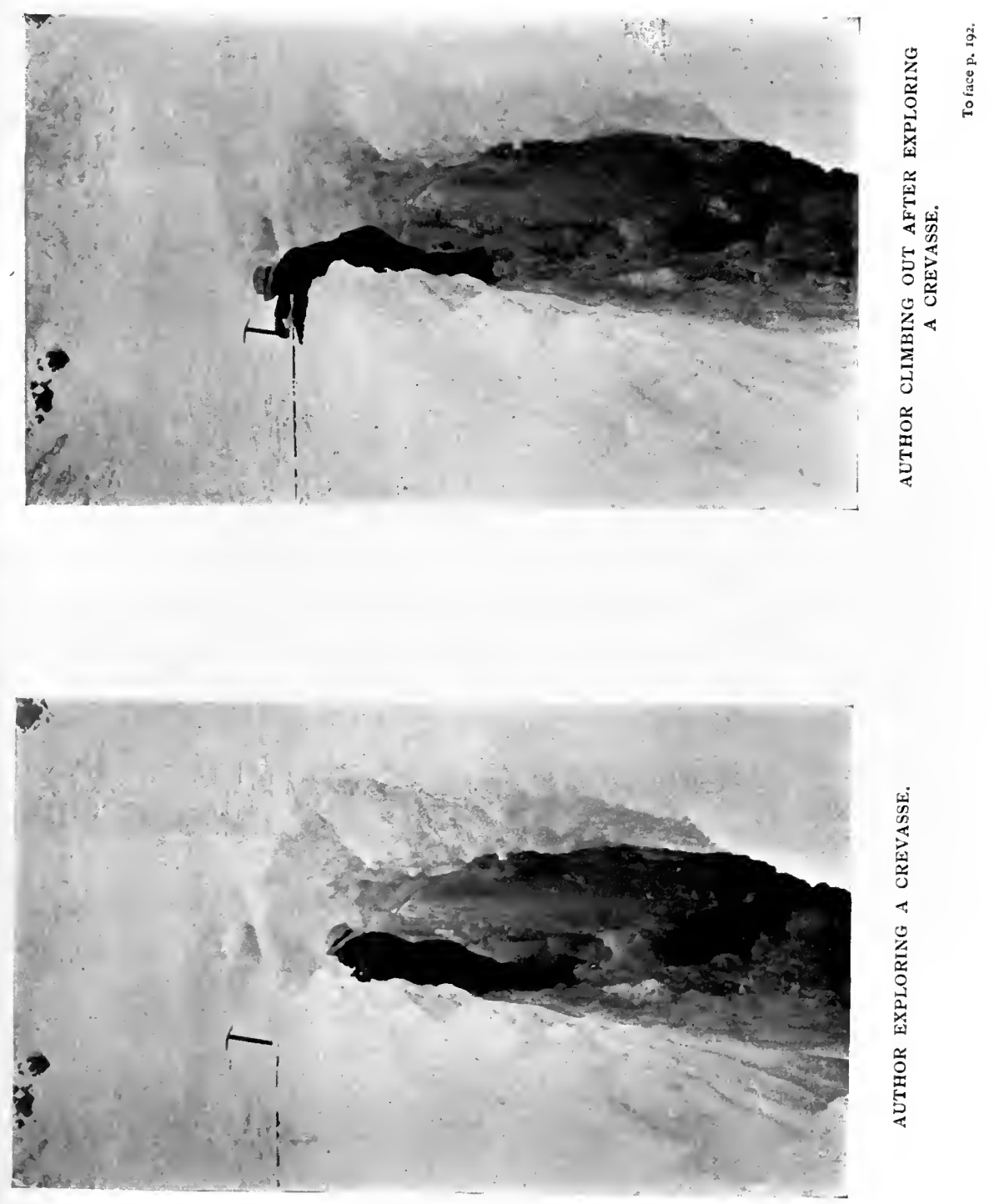

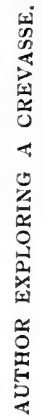





\section{Winter Climbing in New Zealand}

knees in soft snow, and some one murmured about the difficulties. I again took the lead and plodded on. It became steeper, and then we came to an ice slope, up which I cut steps in face of a northwest wind, which plastered me with ice. The ice slope was only about 50 feet. It was with a feeling of relief that I gained the top and took a turn to the left, along what appeared to be a huge crevasse full of snow. I crawled over what seemed to be the safest part of it, and we were soon nearing the main gradual snow slope leading to the summit. I thought the mountain was conquered, but I had not counted upon the storm increasing.

When we reached the ridge we were nearly blown off several times: and although we were close to the last bergschrund, just past it and within 300 feet from the summit, we were making such slow progress that the impossibility of the task became apparent.

I asked my companions what they thought of it, and they replied, "Not much," and suggested that we should turn back. My companions said they had made up their minds to turn back much earlier, but that they were seeing how far I would lead them. One hour and perhaps less would have 


\section{My Climbing Adventures}

seen us on the summit, but the ice-cap was too slippery to stand on in such a strong wind. We practically threw away our chance of gaining the summit of that peak by starting at 2.30 A.M. instead of 12 midnight. Mount Elie de Beaumont has no protection by the Mount Cook range from the north-west wind, and the snow and bits of ice are blown up and over the summit like a dense snowstorm, the bits of ice stinging the face. On our way down we were covered with ice and snow, and the severe wind made it impossible to see more than 2 yards ahead. For the last four hours the storm had hidden from view any of the séracs or landmarks one might take as a guide. This led to an argument between Ross and Fyfe as to the route. I quickly made up my mind that if we were going to be lost I would do the losing myself, rather than let anyone else lose me; but, on the other hand, I had confidence that I could lead them off the mountain all right. Some time afterwards, bending down close to the snow slope, I could see our former steps almost covered with ice. Carefully climbing down the steep ice slope with a bergschrund full of loose snow on our left, I recognised two séracs which I had photographed coming up during a lull in the storm. We jumped I94 


\section{Winter Climbing in New Zealand}

the crevasse and quickly walked across the icebridge and hurried past the huge overhanging séracs, and we were practically off the mountain. I commenced a standing glissade down a groove which had been made by an avalanche. A little way down this groove I stopped glissading, and shouted to my companions to stop, but they did not hear me in the storm. We were getting too much speed on. Ross twisted his leg under him against a piece of ice on the slope.

We rounded several huge crevasses, and, despite the storm, had got safely off a most difficult mountain. We paused on the slopes, and Ross took a photograph of Fyfe and myself covered with ice. I had an icicle sticking to my moustache when I arrived at the Malte Brun Hut. We were anxious about the party whom we had seen sheltering under the ridge of the Dome's second peak, so we walked quickly down to the Malte Brun Hut. We found the party were back, having climbed very quickly to the second peak of the Dome in six hours. The Dome is the usual beginners' climb. We had almost completed our climb in seven hours. Dr Fitchett, one of that party, said that while they were sheltering under the Dome ridge they had seen us plodding in very deep snow; the drift- 


\section{My Climbing Adventures}

snow and ice swirling round and round until it gradually enveloped us, and we were lost from their view. Dr Fitchett expressed his surprise at our keeping on in such a storm, and felt anxious about our return. The one great difficulty about this climb was the very soft snow, which we sank in up to our hips, and had to get out of by climbing up on all fours. Mount Elie de Beaumont is the most exposed mountain on the Mount Cook range, next to Mount Cook ; and being at the head of the valley, and 10, 200 feet high, it has clouds and mist covering it when other peaks are clear. My companions complimented me on my good leadership up and down the mountain in the storm; and particularly on the way I had led them out of the danger of losing our way. This, our first attempt of Mount Elie de Beaumont, shows that the mountain could have easily been conquered by us in good weather, because it was virtually conquered in a gale.

Our Second Attempt on Mount Elie de Beaumont

The storm had not abated on the high mountains for twenty-four hours after the return from the first I 96 


\section{Winter Climbing in New Zealand}

attempt until the last three hours before midnight ; and as it then looked like clearing up we decided to start at midnight, having had a lesson about the drawbacks of a later start. It was one o'clock before we actually started down the zigzag path to the glacier. The lantern helped us to see the crevasses, and we made moderate progress in rather soft snow, Fyfe leading. After about half-an-hour Fyfe complained of the deep snow, and Ross asked me to lead, so I asked him to try the lead himself.

A few minutes later Ross remarked that the snow was too soft to climb the peak; and as he seemed to put a damper over the climb by these remarks, I suggested that he should return and Fyfe and myself would continue the climb.

He did not take my suggestion, so I took the lead, and led with less than five minutes' stop for about three hours, plugging fresh steps in soft snow about 9 inches deep. The soft-snow difficulty was nothing to compare with the wind they call north-western, which became threatening. All the crevasses had been covered by fresh snowdrift, and our legs slipped into them as we neared the slopes leading up to Mount Elie de Beaumont.

We could not see the peak, and the clouds were travelling at a terrific rate. We decided to climb 


\section{My Climbing Adventures}

over the Lendenfeldt's saddle to shelter from the wind and wait for the weather to clear. On reaching the summit of the saddle the wind was quite as violent as on our first attempt, and although we descended a little way on the west coast side, there was no shelter. We crossed near the edge of a snow cornice (an overhanging ledge of hard snow). Ross and Fyfe were the first climbers to climb over this saddle, and our party was the second. I had, by crossing over the saddle, completely traversed the great Tasman glacier. This saddle is 799 I feet above sea-level, but you start climbing very near sealevel.

We waited about, taking photographs for about an hour, and the storm seemed to get worse on the peaks. It was with a very sad heart I gave way to the persuasion of Fyfe and Ross to give up the attempt. A severe thaw set in, and the snow became softer and deeper; and later on the weather became more broken up, so I suggested going down to the Ball Hut as quickly as possible. This was not too soon, because all along the glacier we could see by the streams of water running down that the thaw was. a very severe one.

We luckily escaped a very heavy shower and afterwards a wind-storm, which shook the Ball Hut. 198 


\section{Winter Climbing in New Zealand}

violently. It was suggested by Fyfe that we should have three days' rest to enable Ross to get his ankle better-he was limping badly after the Mount Elie de Beaumont climb, and Fyfe's heel was bad.

The following morning, in torrents of rain, Fyfe and $I$ went down to the Hermitage, the weather having broken up. It continued bad for seven days, and we became very despondent, thinking that we should not get the slightest chance of climbing Mount Cook, the height of our ambition. After many debates about the weather, it was decided that February and March are the best months for climbing in the high mountains. The tourists' season is from the Ist of December to the end of April.

To keep in training for Mount Cook, I indulged in skipping-rope exercise, etc.

The one serious drawback to bad weather is that you get out of condition, and it is necessary to keep in the pink of condition to climb the high peaks.

While we were storm-bound in the Hermitage we appreciated the very well-organised manner in which $\mathrm{Mr} \mathrm{M}$ 'Donald, the caretaker, runs this "Home in the Mountains." The comforts are exceptional for a place so out of the way. The cooking of the food at the Hermitage is better than any I have met in New Zealand. The accommodation at 


\section{My Climbing Adventures}

the Ball and Malte Brun Huts are exceptionally good and reasonable-Ios. per day for the Malte Brun Hut, which is over 5500 feet above the sealevel, is very much cheaper than anything in the Swiss Alps, and a very large stock of tinned provisions, fruit, etc., is kept at the huts. There are, however, only the Ball Hut and the Malte Brun Hut in the Mount Cook district, and there is not a single hut on Mount Cook or near its slopes. In this respect, climbing in the New Zealand Alps is very much like exploration. There were no guides, porters, or huts on the mountain, and one has to carry one's own swag, rucksack, etc. I was very much disappointed in not having $\mathrm{Mr}$ Clarke as our guide, because he is in every respect a first-rate climber. As he was unable to come for the expedition to Mount Cook, Messrs Fyfe and Ross suggested Mr P. Graham, and I readily agreed. At that time Mr Graham was chiefly a glacier excursion guide, and occasionally he had taken parties to the Dome. He has since climbed most of the most difficult peaks, and is an exceptional climber. 


\section{CHAPTER XI}

THE MONARCH OF THE NEW ZEALAND ALPS-THE FIRST AND ONLY TRAVERSE OF MOUNT COOK

SUGGESTED to Messrs Ross and Fyfe that

1 we should make the first traverse of Mount Cook instead of a climb. At first it was thought impossible, but in discussing the matter we decided that if we could get a party to take a tent up the Muller Glacier for us to sleep in when we got over the mountain and down the other side, it would make the traverse quite possible, as regards the number of hours we should be on the go. This was our intention right up to the time that bad weather broke out. Then when we left the Hermitage for the second time, we were so uncertain about the date we should climb, that it became impracticable to have a party waiting for us on the other side of the mountain.

I cannot do better than quote the following article that appeared in Truth, New Zealand, 16th January 1906, as a fitting introduction to the traverse of Mount Cook. 


\section{My Climbing Adventures}

\section{The Ascent of Mount Cook}

\section{Previous Attempts}

In view of the successful ascent of Mount Cook by Mr Turner, F.R.G.S., and party, the following particulars regarding previous attempts are interesting :-

It is over twenty years since the Rev. Mr Green, a noted English Alpine climber, first essayed what was then considered the impossible task of "topping" Mount Cook. This gentleman, aided by the brothers Kauffman, Swiss guides, whom he brought with him from Switzerland, spent altogether six weeks in various efforts to make the ascent, and on the last occasion got to within 300 feet of the top, but thick weather coming on he had to beat a retreat.

Almost every season since then parties have been formed to endeavour to conquer the "cloud-piercer." Pioneers in this respect were Messrs Clarke, Fyfe, Mannering and Ross, the well-known Wellington journalist.

In $1894 \mathrm{Mr}$ Fitzgerald, an English gentleman, who devoted a great deal of his leisure to Alpine work, left England for the purpose of spending the season in New Zealand, his chief object being to make the ascent of several of our "maiden" peaks. He made arrangements with that noted guide, Zurbriggen, whose name is wellknown to Swiss climbers, and arrived in the Colony in December 1894 .

The New Zealanders, who had been making attempts for years to conquer Mount Cook, were very loth to see the honour wrested from them by an outsider, so a party, consisting of Fyfe, Graham and Adamson, was organised, 



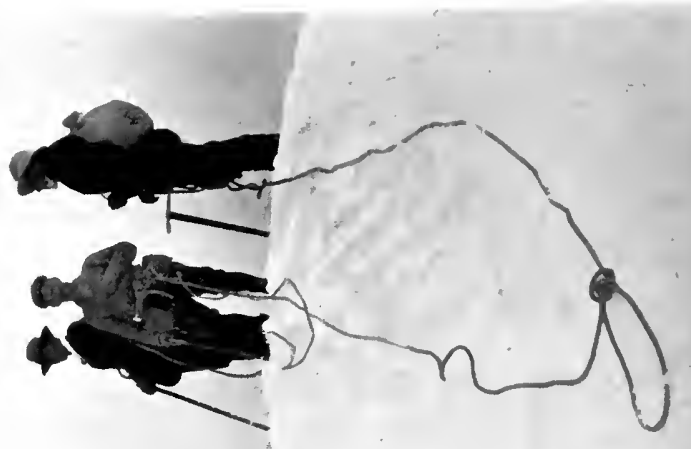

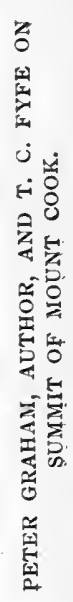
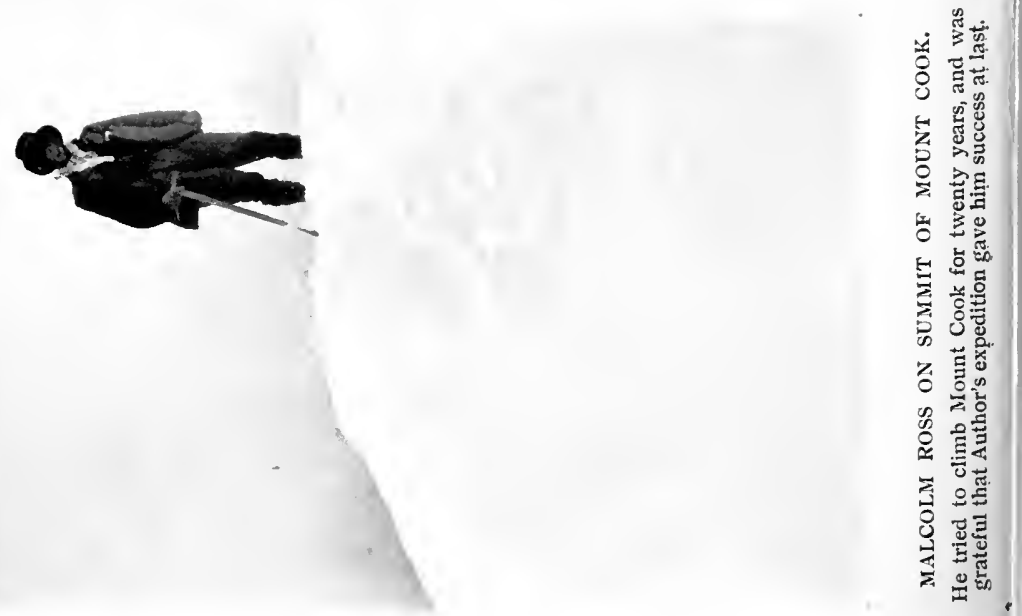


\section{First Traverse of Mount Cook}

their efforts at last being crowned with success, for on Christmas Day I894, the summit of "Aorangi, the cloudpiercer," was reached, and the honour of first making the ascent of Mount Cook, New Zealand's highest mountain, was thus secured for New Zealanders. On the way back to Timaru, the party met Fitzgerald and Zurbriggen on their way to the Hermitage, and Fitzgerald's disgust was so great at being beaten, that he would not make the attempt. He, however, made the ascent of Mount Sefton, and, so far, he and Zurbriggen have the honour of being the only mountaineers who have reached the top of that mountain.*

Since 1894 various attempts have been made to ascend Mount Cook, but until last year none were successful. In February 1905, a party consisting of Clarke, Graham, Dr Teichlemann, Rev. Mr Newton and Mr Low reached the top at 4 P.M., and had to spend the night at an elevation of 11,000 feet, it not being considered safe or prudent to attempt to reach the camp. On this occasion the party were roped together for thirty-five hours.

It is no wonder that this mountain has such a fascination for Alpine climbers, and at the present moment there are three English gentlemen in New Zealand who have come here with the idea of scaling Aorangi. One of these gentlemen, Mr S. Turner, F.R.G.S., is the organiser of the present successful party. Mr Turner has done a lot of mountaineering in Switzerland, Siberia, etc. He has written a book on his travels in Siberia. In November of last year $\mathrm{Mr}$ Turner made arrangements with the Government to release $\mathrm{Mr} \mathrm{T}$. Fyfe from his duties in Wellington; and, accompanied by $\mathrm{Mr}$ Fyfe and $\mathrm{Mr}$ Malcolm Ross, made a start from Timaru on 7 th

* Since climbed by Captain Head. 


\section{My Climbing Adventures}

December. The last news received in Timaru from the party was that they were camped at the Malte Brun Hut. This was during Christmas week. Mr Turner's arrangements were that the party should rest at the Bivouac (at an altitude of 8000 feet), for twenty-four hours, so as to be fit for the final climb. This intention was evidently carried out, a start being made probably soon after daylight, as on neither of the previous occasions has the summit been reached so early in the day (I P.M.).

This paper gives a brief history of Mount Cook, which the New Zealanders are proud of. The paper constantly refers to the ascent of Mount Cook, whereas we made the first crossing or traverse over the Mount Cook summit and down the other side.

The Monarch of the New Zealand Alps The first and only traverse of Mount Cook

It was $\mathrm{Mr}$ Donne's enthusiastic description of the New Zealand Alps, and particularly Mount Cook, which made me determined to climb it.

My companions, Fyfe and Ross, had been training for six months, and we persuaded $\mathrm{Mr} \mathrm{P}$. Graham to climb with us. We were a strong party, equal to any peak in New Zealand: but we had to wait for good weather. The snowfall was the heaviest on record, and we made the best of 204 


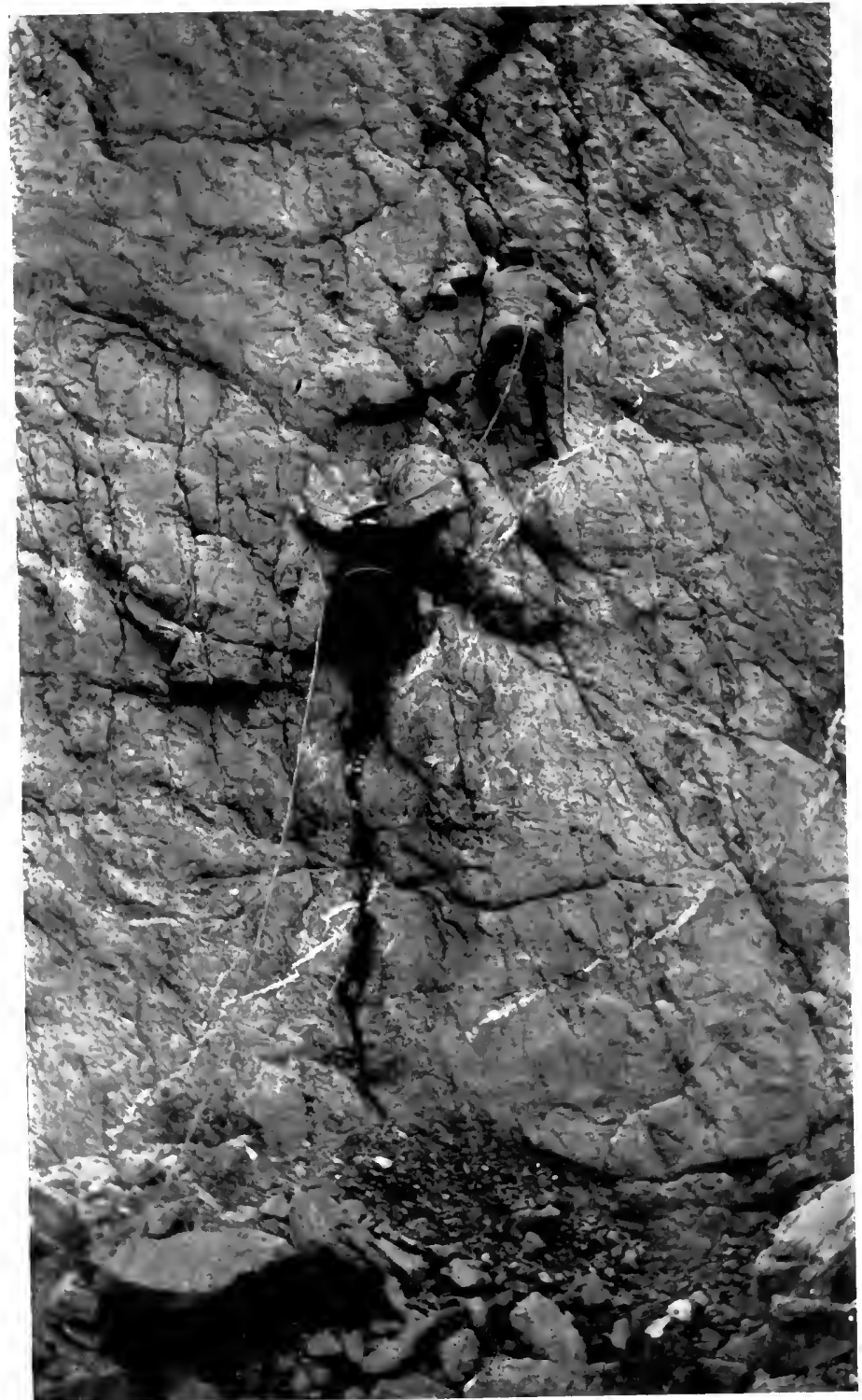

ALTHOR LEADS T. C. FYFE AND PARTY LP MOUNT COOK BLTTRESS. 


\section{First Traverse of Mount Cook}

things for a day or two at the Hermitage. The Hermitage is reached by coach, 96 miles from Fairlie, which is reached by rail from Timaru. The Hermitage, which nestles at the foot of Mount Sefton, is built at a height of 2506 feet above sealevel, in the midst of some of the most notable peaks in the Southern Alps, and is as near the snow-line in New Zealand as any of the Swiss châlets, at 7000 to 8000 feet, are to the snow-line in Switzerland. On Mount Cook itself there are I0,000 feet of climbing on the Hooker side, and 9500 feet on the Tasman side. This is actual climbing (not walking), and is very much more difficult than the last 5000 feet on the Matterhorn. Therefore, as there is no possible chance of placing a high camp on the mountain, and there are no ledges to sleep on, the traverse over the summit and down the other side may be described as a feat in mountaineering. At least we thought so, as we had never heard of such a big climb being attempted, especially where the party had no stopping-place to camp in.

A climb of Mount Cook (which had baffled so many English Alpine-club members and other firstrate climbers) means that the 4000 feet of very steep snow slope has to have steps cut into it to climb N 205 


\section{My Climbing Adventures}

to the top of this slope. But if the party are only making a climb they come back the samé way, walking down the steps already cut ; whereas on our traverse we had not only to cut up the 4000 feet of ice and snow slope up the Tasman side, but after reaching the summit we had a still more difficult task of 3500 feet of an ice slope at an angle of 45 degrees down the Hooker side. As much of this is on a steep slope of ice at an average angle of 50 to 60 degrees, it is much more difficult to cut steps down than up. The traverse or crossing is two or three times as difficult as the climb, owing to the dangerous position in cutting steps while stooping downwards: and the exceptionally long time required on such an exposed mountain slope. Moreover, one of the chief difficulties and dangers in the New Zealand Alps is the sudden change of weather. The fiercest gale may spring up on the most promising day-a gale so powerful, that it is impossible to stand against it.

On 6th January we left for the Ball Hut, I4 miles away on the Tasman glacier. With all our outfit on two horses, we spent that day and night in the Ball Hut, but were disturbed early in the following morning by the keas (almost tame parrots) sliding down the corrugated iron roof of the hut. 206 


$$
-
$$




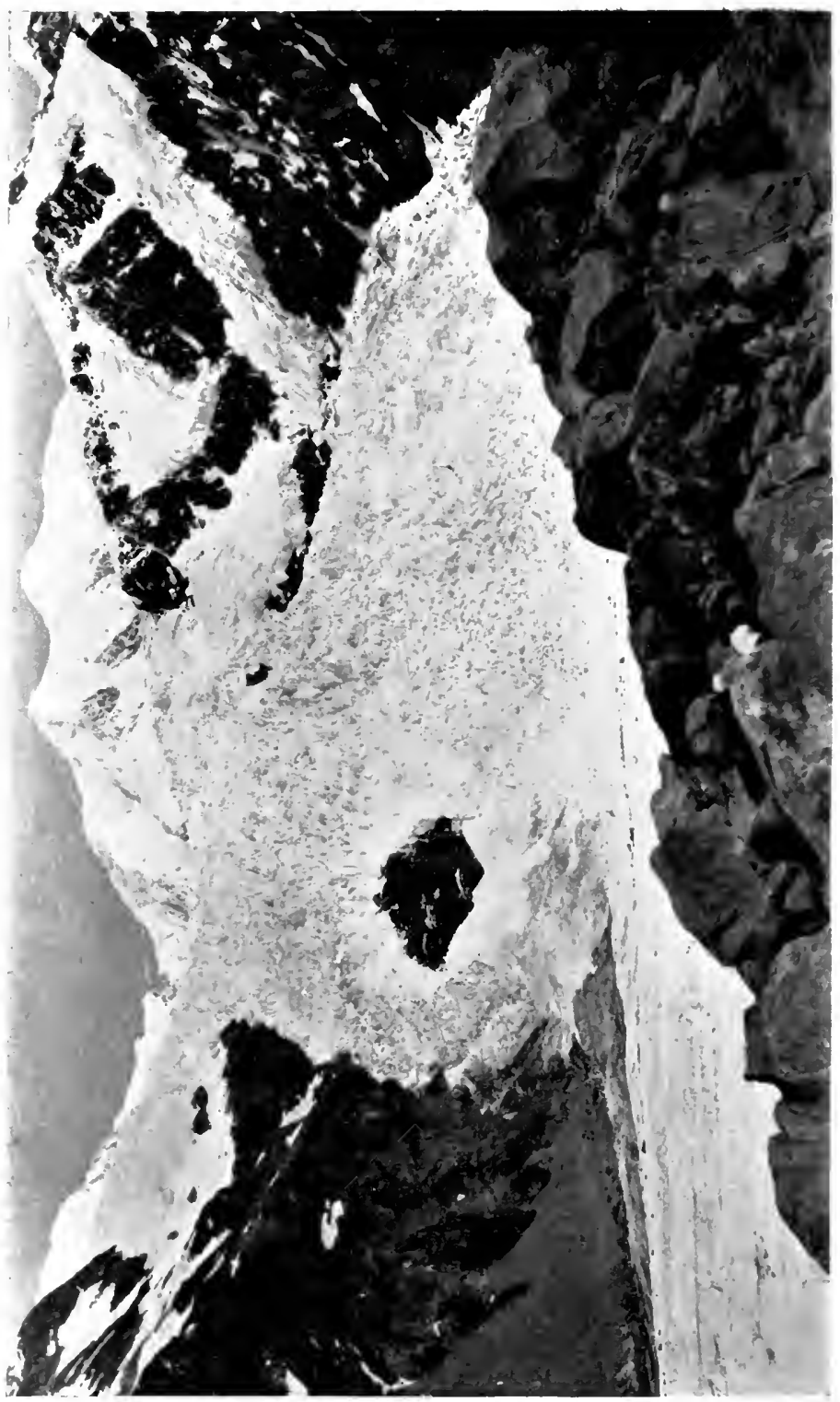

昰 


\section{First Traverse of Mount Cook}

We overhauled our kit and started at eleven o'clock, each with a swag of 30 to $40 \mathrm{lbs}$. on our backs, a porter from the Hermitage being engaged to carry our sleeping-bags and small tent as far as the Bivouac on the Haast ridge. We passed the Hochstetten ice-fall on our left over rough boulders. We had some good rock-climbing for about 4000 feet before we reached the Bivouac, which is a narrow ledge under a huge boulder at a height of 6600 feet, situated on a steep narrow couloir, or gully. We made a fire with small blocks of methylated spirits, and with the aid of a few sticks boiled the water, made some tea, and were soon enjoying lunch. Threatening clouds began to gather round us; a lower stratum of cloud spread itself like a white sea about 1000 feet below us. At five o'clock we lay down to rest, and found the sleeping-bags, lent by the Government, very comfortable. We intended to rest at this Bivouac all the following day, and start climbing the following night. It snowed after we had turned in, and we awoke to find the morning warm but cloudy. Over our breakfast of cold mutton, bread, tea, and jam, we discussed the prospects of climbing Mount Cook on the freshfallen snow, and were all agreed that it was impossible at that moment, owing to its avalanchy 207 


\section{My Climbing Adventures}

state. I climbed some rocks above the Bivouac, and waited a long time to get a snapshot of Mount Cook; and while I waited for the clouds to lift to enable me to watch the mountain, I took out my watch and made a stroke with a pencil on some paper for every separate avalanche I could hear. In the first five minutes there were sixteen, in the second five minutes fourteen! The mountains were in an exceptionally bad and dangerous condition. After lunch Graham and Fyfe started off to kick steps up the Glacier Dome, to save time in cutting them when the snow froze at night, while Ross and I tried to sleep. When they returned we had another meal and another discussion about the state of Mount Cook. I insisted that the avalanches we could hear were not on Mount Cook, and if they were, it would so clear the mountain that it would be practically free of avalanches on the morrow. Ross talked about provisioning the Bivouac and staying up a month rather than be beaten by it. I said I would climb alone if they would not climb. Fyfe said: "What if we cannot get across the snow plateau?" I said I would lead across it, no matter how deep the snow. Graham was silent. Then I proposed that we should retire to rest, with the intention of climbing at midnight. 


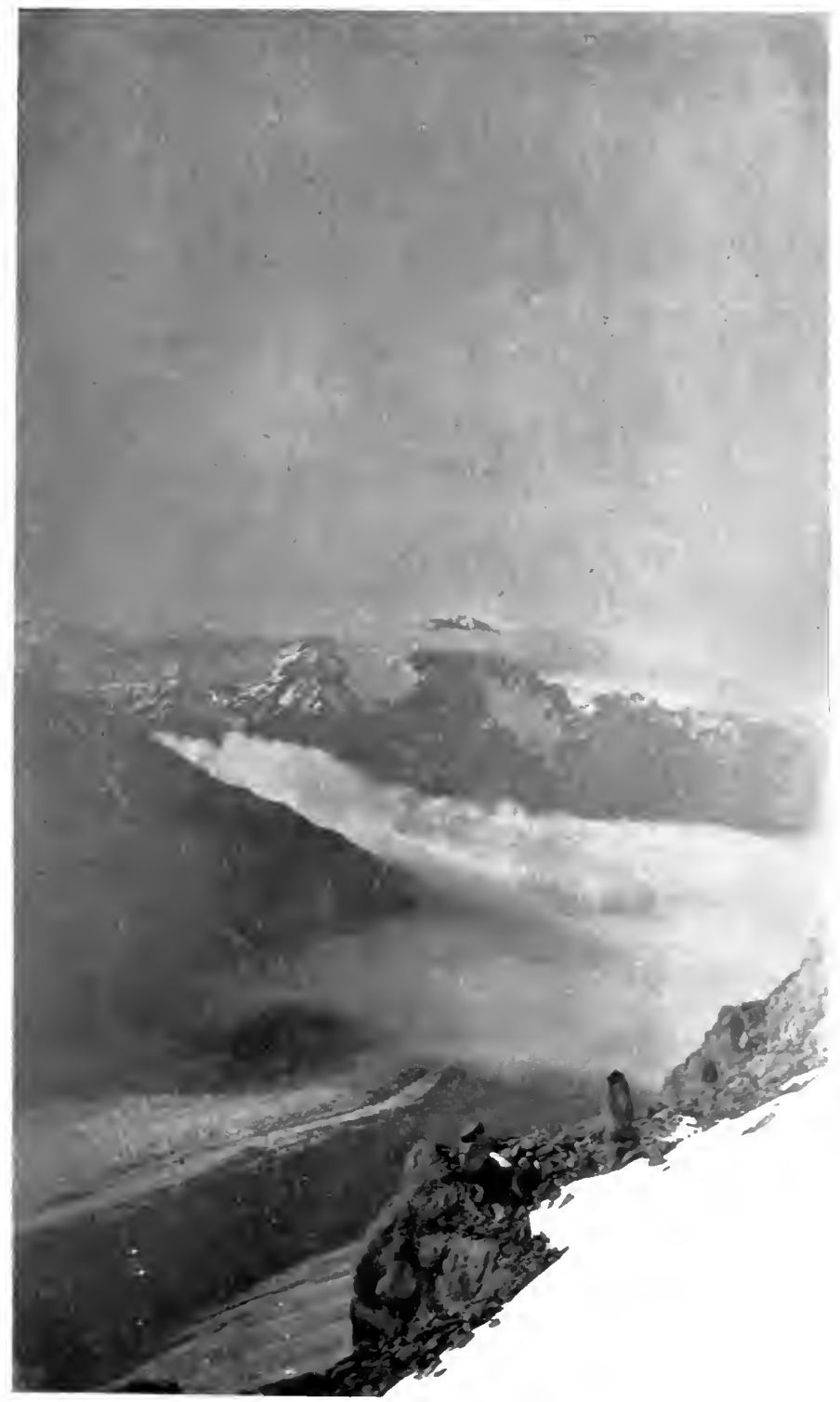

STEEP SLOPES NEAR MOLNT COOK IBIVOLAC AND LIEBIG R.NGE, WITH MOENT PRIEST'S CAP IN THE DISTANT CLULDS. 



\section{First Traverse of Mount Cook}

This was agreed to. Slight misty rain about nine o'clock (which I argued was a sign of heat) made my companions still more against climbing.

I called my companions' attention to the full moon, which I could see through the tent roof, showing that the clouds had lifted. I shouted out at the top of my voice-- "The moon, the moon, we'll climb Mount Cook or die in the attempt."

This enthusiasm at that particular time was the turning-point. In the climbing or non-climbing of Mount Cook I had told the party several times that they had too much respect for the mountain.

It was by moonlight we intended to get over Glacier Dome and the Grand Plateau. At ten o'clock' we had the last full meal we should get before we arrived back at the Hermitage, for we could not take much food with us. As it was, I. carried a 7 -lb. camera, with films, change of clothing, rucksack, and one or two other things.

We left camp at I I.I 5 P.M., quickly climbing up the ridge and over Glacier Dome, some 8000 feet above sea-level. We then descended to the snow plateau, which is a huge basin about 3 miles long and nearly 2 miles wide. We were about an hour or two too late to get much benefit from the moon, which was fast vanishing; so it was necessary to 


\section{My Climbing Adventures}

push on in the diffused moonlight reflected from Mount Cook's precipitous slopes. We began to ascend steep slopes dangerously near ice-séracs from Mount Cook's rocky ridge, which were cracking all the time we were near them. Both Graham and I repeatedly looked up, expecting an avalanche; and while we paused for Fyfe to take his turn at leading and to be freshly roped, we saw a huge sérac, hundreds of tons in weight, crunch its way down into an enormous bergschrund, a huge crack near the rocks, the rocks slanting under the ice. It rocked from one side to the other on its way down, and buried its whole length. The ice all round seemed to shiver. It set us on the move up the slope, as we were too near a wall of ice with séracs cracking ready to break off. Graham crawled along the edge of a fin of ice which crossed a crevasse, and gave us the start to the very steep slope. We were very lucky to get on to this slope so easily, because there seemed to be no way across a wide deep crevasse, 200 or 300 yards long, with the upper lip higher than the lower. We were glad when we commenced this extraordinary steep long slope. This is the surest way to reach the ridge of rocks 2700 feet higher up the mountain. The first slope must be 3000 feet long without a break; 


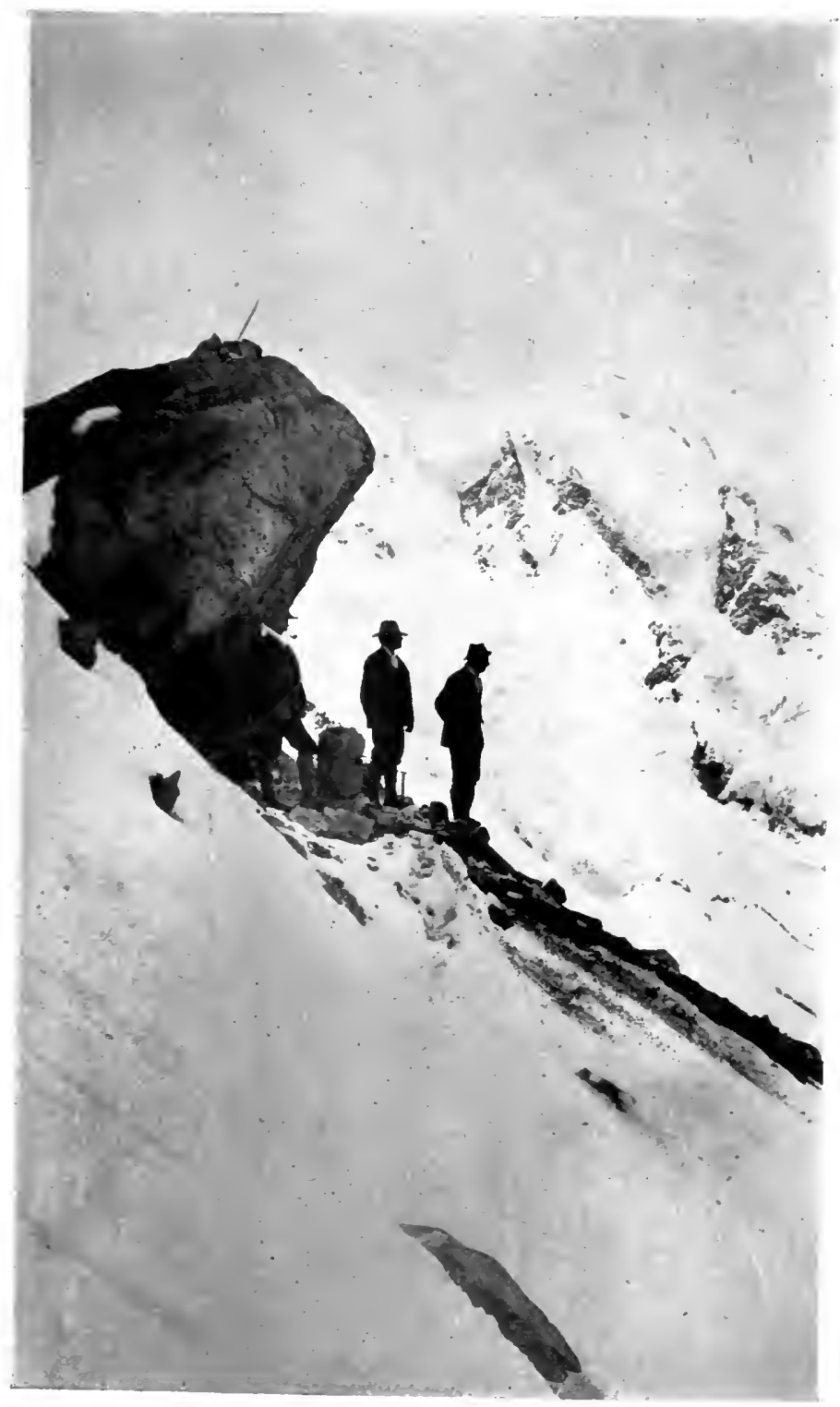

MOUNT COOK BIVOCAC ANI AC'THOR'S PARTY. 


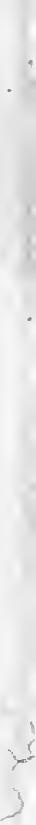




\section{First Traverse of Mount Cook}

it is at an angle of 50 to 60 degrees, and reaches from 7200 feet to 9900 feet, where it joins the upper rocks of the main north-eastern arête. We were pleased to find that we could kick steps some of the way up.

The slope required all the careful climbing possible, and it prevented us from taking more than a glance at the beautiful morning tints; and, later, the sunrise of a most adventurous day. Eventually the great slope was finished, and we stood on a rocky, snow-capped ledge at 6.40 A.M., at a height of 9900 feet above sea-level. Now came some delicious rock-climbing which felt safe after that avalanchy snow slope. The rocks were almost vertical for about 150 feet, on to a narrow shoulder, a short walk on soft snow, and another precipitous rock climb. There were a number of shoulders of rock covered with snow, and the sides could be climbed up, being good rock, with plenty of hand-holes.

The climax came when we wriggled up a shallow chimney (or crack, 2 feet wide) over an overhanging precipice.

It was here necessary to use only the arms, as there were no foot-holds, and after gaining the top of this difficult chimney Graham announced "the Top Rocks." 


\section{My Climbing Adventures}

To gain the summit of the "Top Rocks" we had more precipitous rock climbing, without a pause, than we had had to gain the top of any previous shoulder on the arête; but we were rewarded by seeing the last razor-like snow-corniced, ridge leading to the summit. We rested an hour on the "Top Rocks" and enjoyed lunch. These rocks are what Zurbriggen took to be the summit of Mount Cook, and on a misty day any one would be deceived, owing to the long knife-like ridge, which leads to the summit, taking a dip quite 20 to 30 feet, and afterwards commencing to rise very gradually, forming a corniced ridge of snow, with a sheer drop of 5500 feet down one side of Mount Cook and 4500 down the other side. We rested an hour on the highest rocks, scratched our names on a small empty jam tin, and proceeded at eleven o'clock up the sharp snow arête leading to the summit. I cannot remember a sharper snow arête than the one connecting the summit with the summit rocks. The last 5000 feet of Mount Cook looks like a colossal obelisk of rock, split in two by some powerful element, which has taken most of the summit off the obelisk, and left the sharp edge, about a quarter of a mile long, sloping downwards from the highest summit in a south-westerly 


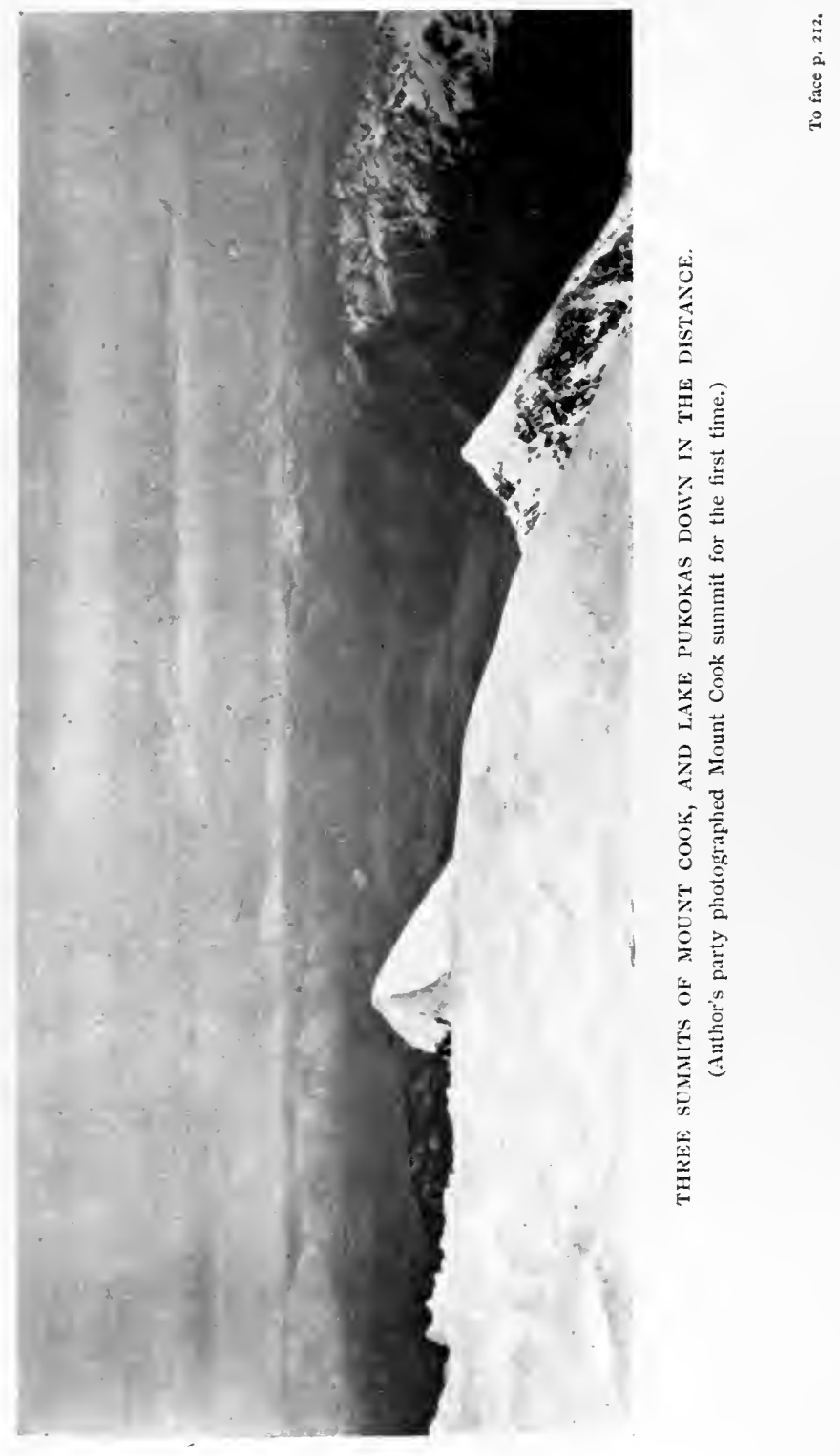





\section{First Traverse of Mount Cook}

direction, consisting of three culminating points or summits.

The highest summit, over which we intended to traverse, is 12,349 feet ; the second summit is I 2, I 73 feet ; and the third I 2,049 feet. The summit ridge is almost zigzag; and on this account the three summits are not visible at the same time in any part of the country. We plodded along carefully for a little over an hour on the sharp ridge, only rising about 300 feet; then we reached the last snow-cap of the summit (500 feet of a very steep snow slope), which took us nearly an hour, and we were walking on to the summit at one o'clock; in exactly thirteen hours forty-five minutes from the Bivouac.

For years I have considered Mount Cook one of the most important and imposing mountains in the world, judging by accounts of attempts to climb it, and also by numerous photographs; and my ambition to conquer it was intensified after I reached New Zealand and learnt what a great opinion the New Zealanders had of this mountain. Some one without my authority had put it in print that I intended to climb Mount Cook, and the idea that the New Zealand public would think I had made that statement and failed, if I did not reach the 


\section{My Climbing Adventures}

summit, made me risk anything to get on its summit ; otherwise I would not have persuaded my companions that the weather was all right, while I knew it was risky and that the mountain was in bad condition. Mr Malcolm Ross had given up climbing, after twenty-five years of attempts, but decided on one more try with my expedition, which proved successful, and he accomplished his ambition.

I had tried to imagine what the panorama was like, and now that view was before me. The day was wonderfully bright; a sea of cumulus clouds extended for about 50 miles in a north and west direction. They were too low to interfere with the higher peaks, about 7000 to 9000 feet high. Heights and depths were bathed in a profusion of light, which formed a striking contrast to the dense, black, huge shadows of the mountains. The incomparable sight appealed to me so strongly that I could hardly speak. I felt overcome by a sense of my own nothingness. These enormous precipices of black and grey rock are void of vegetation or even the humblest lichens, and are only inhabited by desolate and gloomy shadows, increased or decreased by the rising and setting sun. The rock avalanches which we heard reminded me that 


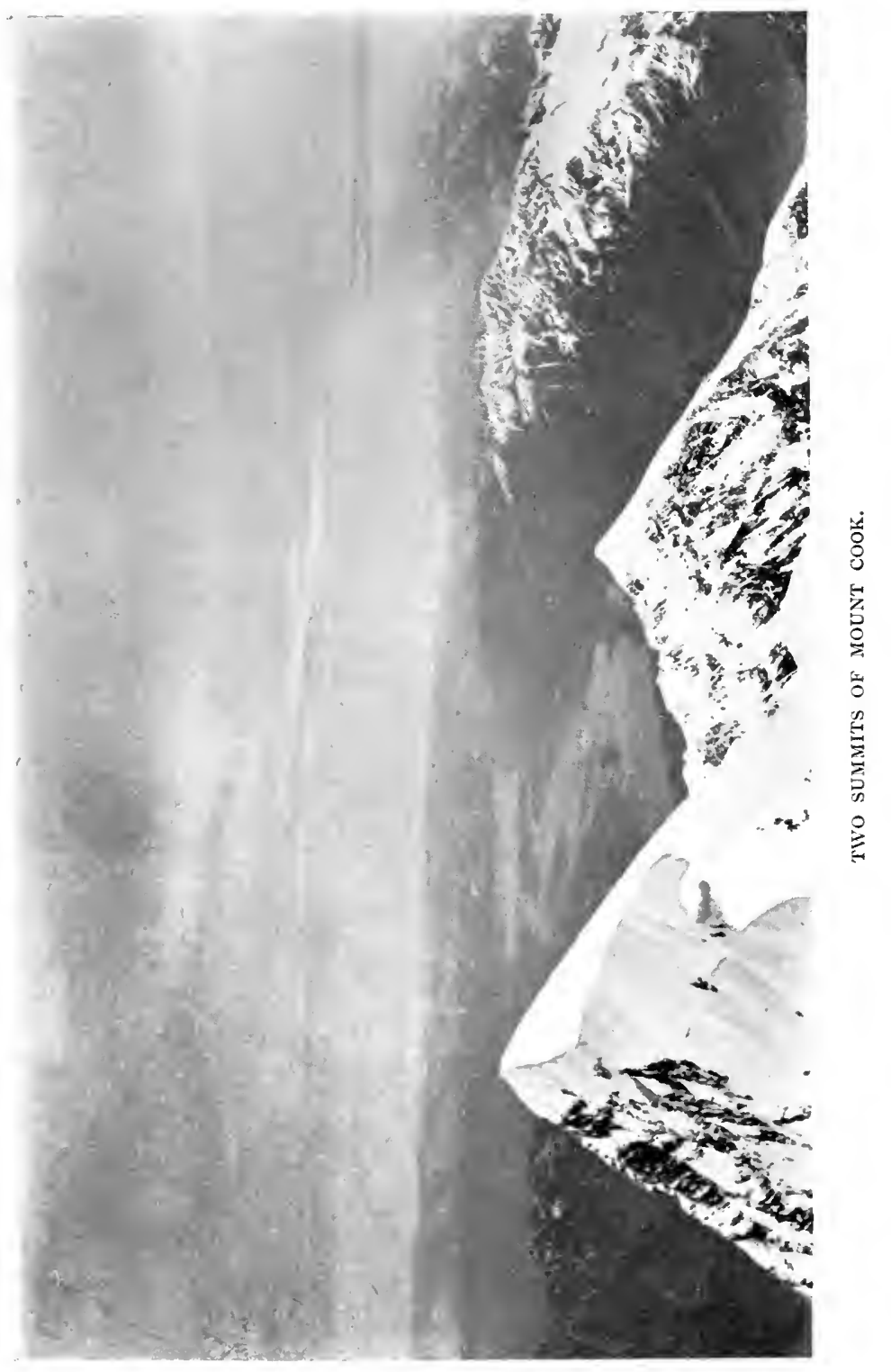





\section{First Traverse of Mount Cook}

Mount Cook's precipitous rock was being splintered and shaped by Nature herself.

The snow, which had melted by the sun, had found its way into cracks and crevices in the rock to await the inevitable night frost. The water had been turned into ice, and in its expansion had burst the rock; but the ice held the rock until the sun became hot enough to release its grip, and then allowed the rock to dash itself from its giddy height, taking with it any loose rock that might be in its course.

I could see the green plains of Canterbury I0,000 feet beneath us in the distance, with pretty homesteads dotted here and there. Between the distant plains and Mount Cook there were the most rugged forms and the most graceful outlines: bold perpendicular precipices and cliffs, with gentle, undulating slopes; rock mountains, sombre and solemn, or glittering with snow, and white glaciers crawling down the mountain-side, split into turrets, pinnacles and pyramids, domes, cones and spires. I could see Lake Pukai, some 55 miles away, glittering in the sun. There was every combination and every contrast that the world of mountains can give or the eye desire. Three ridges of rock dipped down from the summit 


\section{My Climbing Adventures}

on which we stood. One to the north, the other to the south, were very steep; the one which was the Tasman Arête, was the one down which we picked our route. We remained on the summit for twentyfive minutes of crowded but glorious life. We moved down the steep snow slope towards the Hooker ridge, intending to rest for lunch on the first rocks, about 500 feet down. It was too hard to walk down by picking steps, and we had to cut steps for some distance. Fyfe was one of the only three who had ever been up this side of the mountain to the summit before: but as this was twelve years ago, he did not remember anything of the ridge or the route down. He said he could not recognise any of the rocks because of the thick snow on the shoulders of the ridge and thick, ice-glazed rocks on its precipitous sides. We were now cutting down the ice-cap, which was about 150 feet thick over the summit rocks.

Let me explain what Alpine step-cutting is. The ice-axe is about 4 feet long, with a head 8 inches long, a pick on one side and flat on the other, while the shaft has a sharp spike on it. With this axe about a dozen good blows, skilfully directed, cut a foot-hole in the ice from 6 to 8 inches long, and 4 inches deep and about 4 inches 


\section{First Traverse of Mount Cook}

wide. The climber steps into this hole with one foot, stoops down and cuts another step, 15 to 18 inches, lower down. To cut one hundred to one hundred and fifty steps an hour is good work going upwards, but downwards one hundred steps is highly creditable. The climber, while cutting steps upwards, must balance well, but downwards he requires even more careful balancing, because if he overbalances he becomes a danger to the party who are roped behind him.

The difficulty of this traverse of Mount Cook now dawned upon us. To go back by the way we had climbed up-down the steps already cut, and the snow and rocks already tested-we could have put up a record for speed, and been down at the Bivouac before dark. As it was, we were face to face with thousands of feet of step-cutting; down slopes varying from 50 to 65 degrees of an angle, much steeper than the roof of a house, and probably the steepest ice slopes in the world. When we gained the snow on the crest of the shoulder of the first rocks, it was too hard to climb over; so it was necessary to climb down the side and under the shoulder; but on inspecting the precipitous sides, we were much astonished and concerned to find that the rocks had curtains of ice on them. 


\section{My Climbing Adventures}

It was no use standing looking at them, so we became desperate: Graham cut the ice off the rocks and climbed down, I followed him, and as Fyfe and Ross came after us they brushed off pieces of ice which dropped on us and down the precipices on our left. It was difficult to get a decent hand- or foot-hold, even after chipping the ice off the rocks. If the feet just rested upon a small out-jutting rock, and the hand-holes were covered or partially covered with ice, we were quite satisfied to step across space to another rock; then crawling headdownwards, we were just able to scrape the rucksack under the huge icicles, which hung down over the shoulder of the main ridge, and after a lot more ice-smashing down the precipices, we waited under the first shoulder for Ross and Fyfe to follow. As a rule, it is harder for the last man to follow, but on these occasions the first and second man knocked the curtains of ice off and tested the ice and rock-grips, enabling those who followed to get a footing or hand-grip without any trouble or risk. Each member of the party felt that we must put forth all the mettle that was in us if we were to get off the mountain. The climb became very risky, bristling with all kinds of difficulties and as exciting a climb as the heart could desire. The risky jumps 


\section{First Traverse of Mount Cook}

and twists from one piece of rock to the other on the apparently bottomless precipices, were too numerous to describe in detail. We had to climb down the side and round under five shoulders of rock; and each time the ice-curtain had to be cut off and all the gymnastic performances described above were repeated.

The ice-glazed rocks and icicles on the main ridge became worse lower down, and we were driven to try a crack on the right of the ridge which had not been plastered with ice. It resembled the famous Mummery crack on the Grépon-Charmoz ridge, Switzerland, but was not so easy to get into. It was quite as difficult as the Ker Knotts crack in the Lake District of Cumberland. We squeezed into it, and wriggled down like snakes, and towards the bottom we came completely to a standstill. It went over a vertical wall without hand- or foot-holes.

After trying the ridge again, as a last resource, just as we seemed hopelessly stuck, I suggested lowering each other on the rope. Ross was in the position to go first, and he pluckily allowed himself to be lowered the last 12 feet; but he unfortunately cut his fingers through making a slip about to feet from the bottom. Graham climbed down with the rope holding him, but on the last 12 feet his ice- 


\section{My Climbing Adventures}

axe caught in the crack, and he gave a jerk on the rope, twisted half a circle on the rope, pulled the rope out of my hands and nearly pulled me off the ledge, and finally alighted suddenly on a ledge, giving himself a severe shaking. I therefore tried to climb down as far as I could without using the rope, and managed (owing to my being the shortest man of the party) to find hand- and foot-holes, and only needed the rope for the last 3 feet. Fyfe then fastened the rope double round an outjutting rock which had been selected, and he lowered himself down fairly successfully; we helped him from below to negotiate the last few feet. Ross and I climbed off the ledge down another small precipitous chimney, or large crack, out of the way, and the others followed, and we roped up again. The secret of our strength lay in the fact that we now settled down to quiet, methodical, but desperately accurate climbing.

I had cautioned two of our party about talking, making suggestions, etc., and after a slip it became apparent to them that silent climbing was safest. Occasionally some one would get a little excited, and shout something, but that only hindered him, and a quiet serenity generally prevailed. I don't believe it possible for any human beings to have 


\section{First Traverse of Mount Cook}

extricated themselves out of a more dangerous position. No doubt, if we could have accounts of some disasters where the party have been lost, we might get a similarly difficult position; but none of our party expected to get down that ridge without tumbling down it. We felt the difficulties so much at one part of the climb that Graham began to climb down a gully leading off the ridge, but I remonstrated and insisted that we must keep to the ridge, no matter what the difficulties were. When we descended lower we could see that the gully would have landed us down between the Tasman Mountain and Mount Cook, off our track.

The very cold north-west wind sprang up and made us change into our storm-clothes. Then we remembered that we had forgotten all about lunch; but here we could see Green's Saddle, and we partook of a little lunch. This was about 5.30 P.M. Another hour and a quarter's climbing brought us at 6.45 P.M. to Green's Saddle. We had been over five hours in climbing down 2000 feet of rock from the summit to this point. This was the most desperate bit of climbing possible.

The Saddle is over 10,000 feet high from here; there is a snow couloir (that is, a steep slope of snow at an angle of about 60 degrees to 65 degrees) between 


\section{My Climbing Adventures}

precipices. It is over 2000 feet long, and not more than 20 yards wide in its broadest place. The slope is the only way down to the Hooker Glacier slopes. Unfortunately, the snow was frozen too hard to kick steps, and we had to cut them on the ice nearly all the way down. This was very slow and tedious work, and there was a fierce wind driving snow into our faces, up the couloir. We took turns at step-cutting, but Graham was in the best form and worked splendidly; but the sun went down, and twilight and evening shadows gathered round the huge crags and precipices steeped in serene dignity and silence. . Steadily we descended, almost as slowly as the shadow of the moon, whose splendour was hidden from our sight. One hour, two hours, three hours, four hours, and still the stepcutting went on. We began to feel the want of sleep, and talked to one another to keep ourselves awake, as a slip on this ice slope would have been dangerous, if not fatal. It was a minute or two after I had arranged that we should talk to one another that I felt something like an explosion in my head, and all was blank for a few seconds. My body had evidently swayed in the act of falling, because I was brought to my senses by my left hand catching on three small tacks which were left after 


\section{First Traverse of Mount Cook}

the leather band on my ice-axe had worked loose and dropped off, leaving these brass tacks exposed. These small nails not only stopped my hand as it was slipping down the shaft of my ice-axe, but it seemed just sufficient to bring me back to my senses, and make me clutch the ice-axe instinctively at the right moment. Immediately afterwards, I remembered the ice slope, and my precarious position and that of my companions; and to warn them I shouted out: "My head, my head, tighten the rope!"

A piece of a rock-avalanche had struck me on the head as the lump of rock bounded past us down the ice slope. We should have been dashed down the ice slope into a huge bergschrund at the base of the slope if I had fallen, because we had grown careless. The exceptional length of time-about twentyfive hours' continuous climbing, with about two hours for stops - had brought on drowsiness, and made us forget the precautions of backing up with the rope. If I had tumbled on to Graham he and myself would have gone and the others could not have held us. I made the effort of my life not to give way. Every time I felt faint and had to lean my head on my arm, I warned my companions to tighten the rope. 


\section{My Climbing Adventures}

Graham cut steps close to the side after this, but we could not get away from the danger of the avalanches, to which we were exposed for three or four hours after the accident. The occasional whiz of a stone as it shot past and down the couloir reminded us of our perilous position; but, although we descended with reckless haste in some places, only making the scantiest foot-hold, and placing both heels in the foot-hold about 2 feet to $2 \frac{1}{2}$ feet below one another; despite this, the slope seemed to be endless. According to the recognised speed for step-cutting - that is, Ioo feet an hour in ice-this slope should have taken us twenty hours; as it was, it took us between ten and eleven hours. The most serious drawback on this slope was the fact that we were cutting steps all night from six o'clock, just after the sun had disappeared, until between four and five o'clock the following morning, exposed to avalanches and the danger of a slip all the time. The huge bergschrund which is situated at the base of this slope, and which we expected to find almost impossible to cross, was full of snow. In fact, the soft snow off the snow slope had apparently slid down and filled its wide, deep, gaping mouth, and we found a place where we crossed without very much difficulty. 


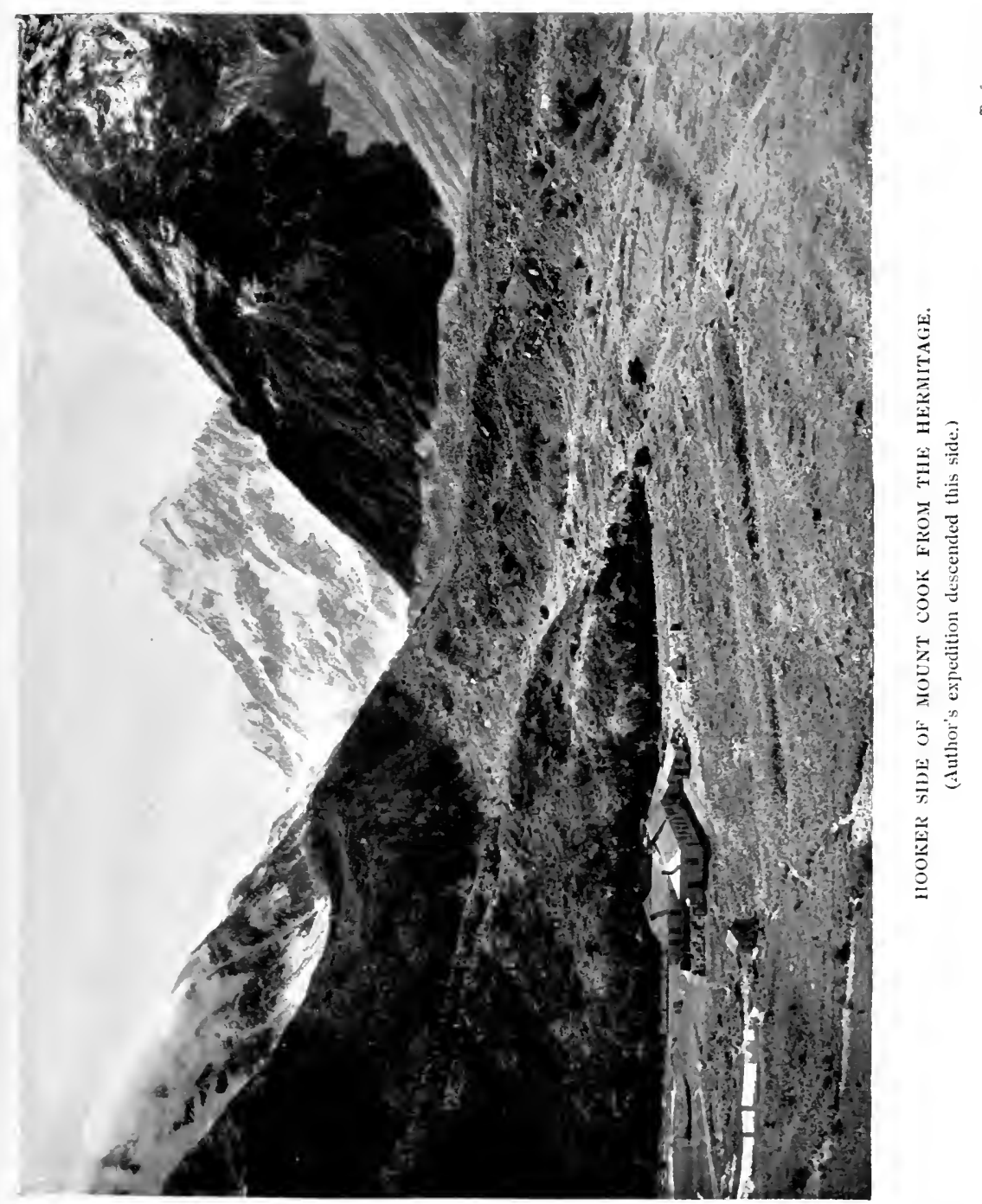





\section{First Traverse of Mount Cook}

This is the chief obstacle to the climb of Mount Cook from the Hooker side. The Hooker side is the easiest way to traverse Mount Cook. From that side you will climb this dangerous snow slope during the morning; and when you come to the great ice slope on the Tasman side of Mount Cook, provided it is full moon, you will get the light of the moon to help you on the ice slope. The way we climbed it we did not get any help by moonlight.

Once across the bergschrund we speedily forgot our troubles, except my head. We had realised our dream of the first traverse of Mount Cook, and that by the most difficult route. We had an early breakfast, but the cold wind made us hurry over our food, and we were soon walking quickly down the Hooker Glacier. The first signs of dawn and the fading moonlight made the enormous ice-séracs and blocks of this glacier a sight not to be forgotten. If you wish to see the most extraordinary effects of ice and snow glaciers and ice-covered rocks, go to the west side of the Mount Cook range, which receives the moist wind from the ocean so close to the mountains.

We became hopelessly lost amongst the crevasses and sêracs time after time, but when we came to the ice-fall it looked as though we should never get 


\section{My Climbing Adventures}

through: the crevasses were hundreds of feet deep and too wide to get across. Two or three ladders would prove very useful on that glacier. While we were unravelling the puzzle dawn changed into daylight, and we witnessed our second magnificent sunrise since we left our Bivouac 6600 feet high, on the other side of the mountain.

The morning developed, but we were still in the crevasses. Once off the ice-fall we travelled down at a good speed to the bottom of the glacier. We each had difficulty in not falling to sleep. We arrived at the Hermitage in exactly thirty-six hours from the Bivouac. We had climbed very fast for such a climb, despite the number of hours, at one stretch. In fact, we were about four hours quicker to the summit than the only previous party to reach it. We were four days and a half from the Hermitage over the monarch of the New Zealand Alps, and back again to the Hermitage.

I slept from twelve o'clock until six in the evening, and was up to dinner, feeling none the worse for the climb, except for the pain in my head. It took a long time to get my cap off, which had been driven into my head by the piece of rock. Mr M'Donald at the time thought the cut rather dangerous, and recommended me to go to Fairlie 226 


\section{First Traverse of Mount Cook}

and see a doctor-Fairlie was 100 miles away, two days by coach, a most trying journey. The doctor said that the piece of rock had struck me on the occiput, the part of the skull which is much thicker than any other part; and that if it had struck me 2 inches at the side of the occiput it would have killed me. This was one more narrow escape, and I began to think I had a charmed life. I was very reluctantly compelled to leave Mount Sefton unclimbed.

The New Zealanders think a good deal about Mount Cook, and not without cause. It is a question if it is possible to find a mountain outside the Himalayas where there is 10,000 feet of sheer climbing from the valley. Mountains that are I 8,000 feet in most ranges in the world are gradual slopes. Where there is a mountain in South America, Africa, Siberia or the Caucasus about I 8,000 feet, you never get 10,000 feet where you have to climb with your hands and feet. Most peaks can be walked up to within 4000 or 5000 feet from the summit.

The last climb I had in the South American Andes illustrates what I mean. There was no rock-climbing with hands and feet, but simply snow walking. The only enemy to the climber is 


\section{My Climbing Adventures}

the rarefied air, which often produces puna, and the very severe cold, which requires a fairly large equipment to withstand; but the difficulty of carrying any weight up the mountain increases the risk of bringing on puna.

\section{Mount Cook}

Several of the most prominent New Zealand climbers express their firm conviction that $M$. Zurbriggen, the famous guide, made a mistake in thinking he reached the summit of New Zealand's highest mountain, Mount Cook. This gave me food for thought, and I read M. Zurbriggen's account of his climb; but on climbing over the top of Mount Cook it seemed clear to me that some mistake had been made, either as to the time he was away from the porter, whom he left at 9000 feet, or as to the actual point he reached. In Zurbriggen's book, From the Alps to the Andes, he says he left his companion at a height of 10,000 feet on Mount Cook, and proceeded to the summit himself, and he came down about 160 feet where he left his card on a rock. In another book, called Unwin's Chap Book, M. Zurbriggen says: "He took a porter with him as far as 9000 feet. The 228 


\section{First Traverse of Mount Cook}

porter was tired, and then he set off alone and gained the top. He quaffed half a bottle of wine, smoked a cigar, thrust the empty bottle into a convenient hole amongst the rocks close to the summit, left his card within it."

There are no rocks near the summit. They are quite 1000 feet below; but if Zurbriggen had been on the snow on the top of the summit rocks he would have been able to place a bottle between the rocks like he says he did. If it had been at all misty the summit rocks would be taken for the summit, - because from the summit rock a very narrow ridge of snow courses downwards for some distance, and afterwards it gradually rises; but so gradual is the rise that the actual snow-capped summit, which is about 500 to 600 feet thick, looks like another mountain in the distance from the summit rocks. Another fact that seems to show that Zurbriggen was only on the summit rocks is the time he was away from Adamson, and the time it took both him and Adamson to get down to the Bivouac, about eight hours. He says he arrived about three, and drank wine, smoked a cigar, and took photographs. This would make it about 4 to 4.30 before he commenced the descent, leaving about seven and a half to eight hours to 


\section{My Climbing Adventures}

get down to the Bivouac, which he says he reached at 12 o'clock. With fast travelling he could get down from the summit rocks in eight to nine hours; but from the summit to the Bivouac is out of the question, more especially as he says he had to go slowly, owing to crumbling snow.

It is the easiest thing imaginable for any party to think they are on the summit of Mount Cook on the summit rocks. In fact, there are two or three apparent summits when climbing up the rocks. The remarks of M. Zurbriggen in his book, and in Unwin's Chap Book, seem to show that the New Zealand climbers' belief that M. Zurbriggen did not reach the summit of Mount Cook is based on a fairly good foundation. 


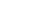




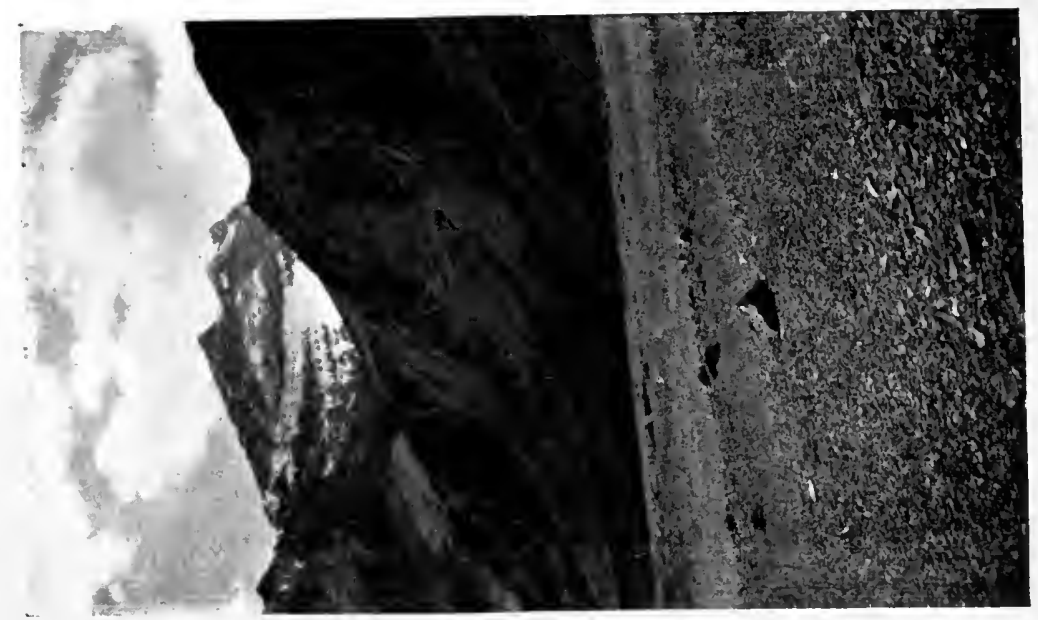

重

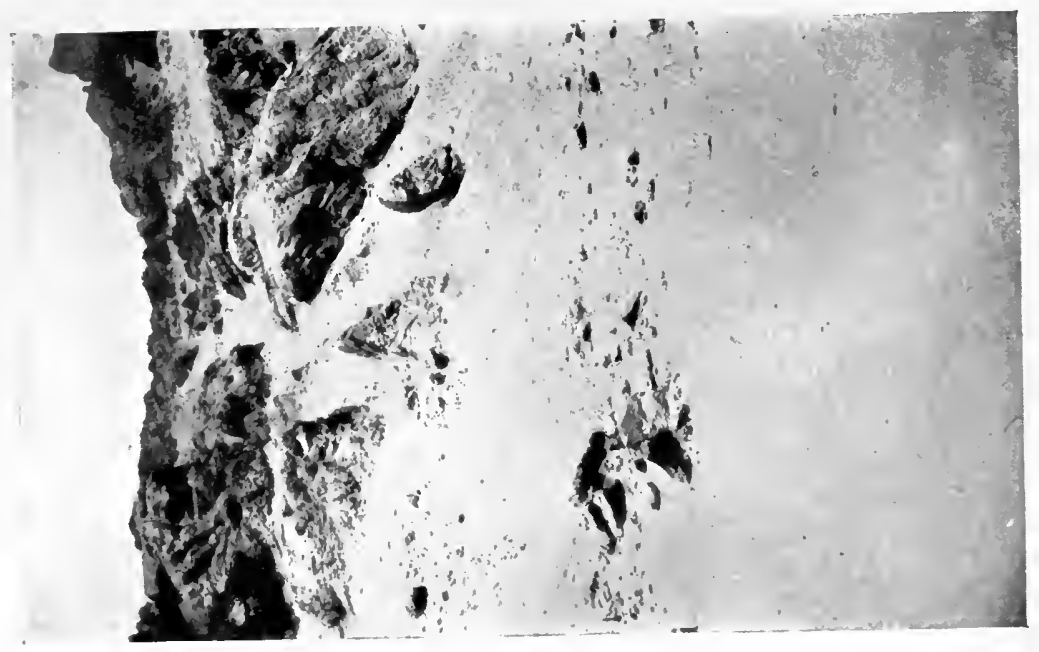

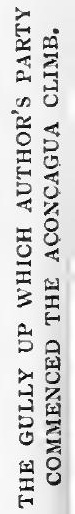




\section{CHAPTER XII}

\section{A SOUTH AMERICAN CLIMB-MY ATTEMPT TO RUSH ACONCAGUA}

I INTENDED attempting Aconcagua in 1906, 1 and during my lecture in Buenos Ayres $I$ invited anyone in the audience to help me. After the lecture, Mr Wedgwood, an Englishman, came forward and informed me that he had just come out of the hospital, having had one of his toes amputated, owing to frost-bite; and that the mountain was covered deep with the first of its winter snow. I had to give up the idea of attempting the climb that year; but in 1909 I went to Buenos Ayres on business, and after finishing my business I found I had seven days to spare. I was quite unprepared, and so were the young men who joined me, $\mathrm{Mr}$ Hardman, Liverpool, and Mr Robertson, a Scotch Canadian. We thought that punchos (a kind of thick cape with room for the head) would be warm enough, and I was able to get my little tent and some tinned goods, which I had left with Dr Lehmann Nietzchie, Anthropologist of the Museum 


\section{My Climbing Adventures}

de la Plata. We had to rely upon the hotel proprietor to provide us with mules, because we had no time to take mules from Mendoza, like other expeditions. I had been in touch with $\mathrm{Mr}$ Larden, who the British Consul (Mr Carnegie Ross) informed me had gone to climb Aconcagua. The following is a copy of the letter I received from Mr Larden :-

$4^{\text {th } \text { March Igog. }}$

Ponte DeL INCA (Leaving).

DEAR SIR,-I have just received your telegram and translated another (as well as an earlier letter) to the manager of this hotel.

I fear you must have been waiting some time for an answer from this manager?

Some hopes expressed to Mr Bolland must have been passed on to Mr Ross, and then to you, and have got altered into something much more definite by the time the report reached you. I am fifty-three, and further, not able to afford the organisation of an expedition; hence, I was neither able to carry heavy loads and sleep out at 18,000 feet in a sack alone, nor able to employ porters to carry tents, etc. Hence I found I was cut off from real ascents. Knowing nothing of the Andes, my hope was to join either Dr Hebling (an extraordinaryenduring Swiss engineer) or Dr Reichert, and I probably expressed to Mr Bolland hopes of Aconcagua or something else. What I did do (and it was satisfactory to be able to do it at my age and with my small resources) was this. I went with Dr Hebling for three weeks and 


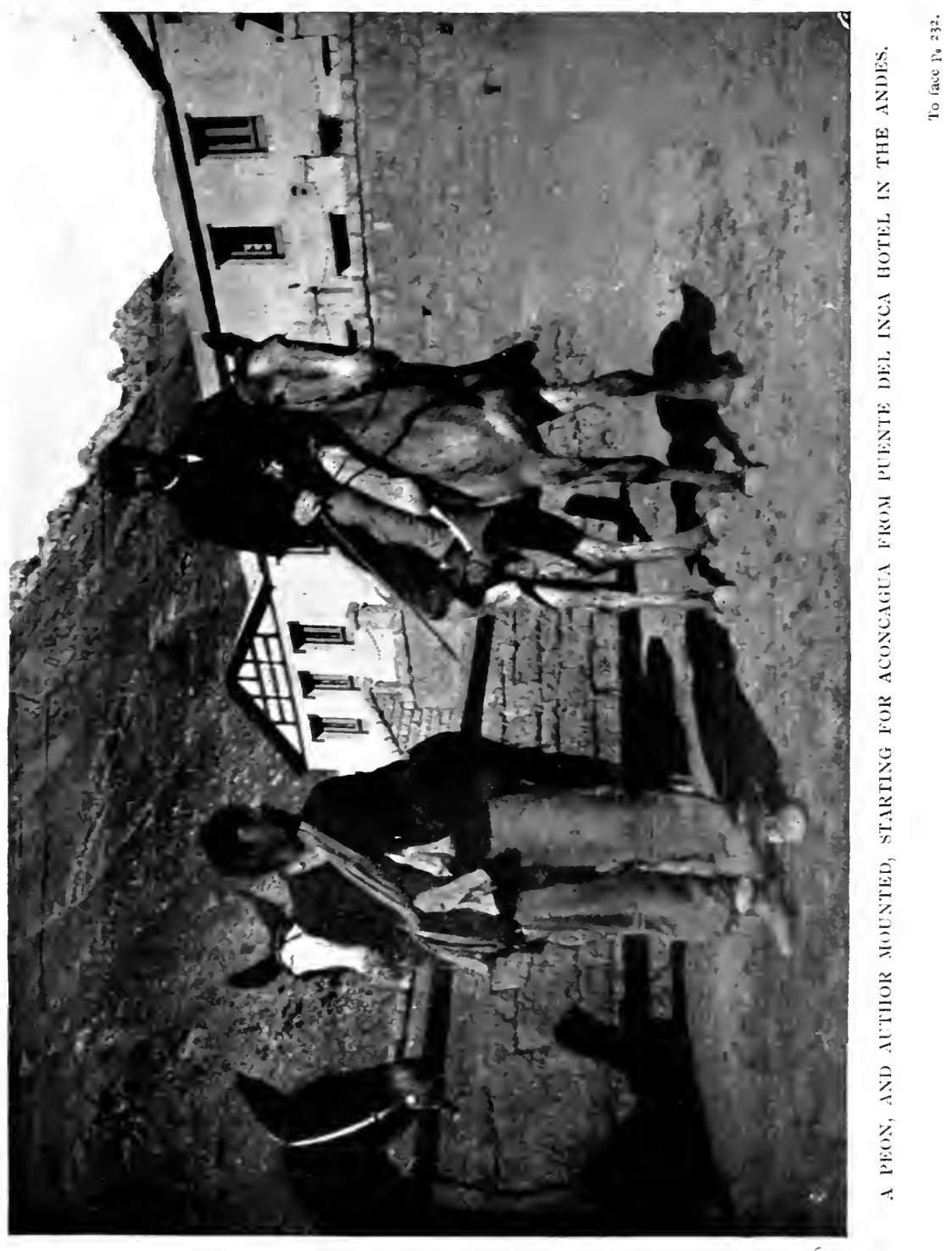




\section{My Attempt on Aconcagua}

two days into the heart of the Andes. Among other things looked into Chile from a hill of, I suppose, between 16,000 and 17,000 feet oversea, besides various other walks up hills, high from a Swiss point of view; got among glaciers, observed Penetenteries, animals, etc.

Dr Hebling takes mules, arrieros (who can't climb) and camps as high as feed and pastures reach; I think some 13,000 to 14,000 feet oversea, but can't be sure. Here was hard frost, and while he was quite warm, I was very cold. Even inside a tent it freezes very hard, and there is usually wind. He then would carry some $30 \mathrm{lbs}$. (bags, rugs, food) up to some 17,000 or 18,000 feet, and sleep out in the most intense cold. For me, it would have been losing feet and fingers, etc., with my eyes open, so I saw that the height of 20,000 feet or more was out of my reach. I needed porters, Conway's eiderdown sleeping-bags and tent.

There seemed to be wind always, and even Dr Hebling failed to get up Tupungano, though it is far eusier than Aconcagua, the wind near the top could not be faced. He slept out three times, I think, very high up. I have only seen the Andes, which demand great carrying power, and a really extraordinary capacity for resisting cold. I hear there are Chilian guides who have nailed boots (the mule-drivers have elastic-sided boots with paper soles and pointed toes), but I fear that I cannot tell you anything about them. The cold and wind are the enemies, and you are absolutely out of reach of proper treatment if you get frost-bitten. I can assure you, however, that a time in the heart of the Andes, with meals round open camp-fires, hard frost at night and wanderings up among glaciers, in which you must rely entirely on yourself, is a form of mountaineering not to be despised. It seemed to me to 233 


\section{My Climbing Adventures}

be beyond the usual climbs, say, traverse of the Matterhorn or the Gabelhorn, or up Lyskamm, which I went one of my late seasons in Switzerland.

On the Andes I have had to talk German to my companion and practise my book-learnt Spanish. with arrieros. I fear you will not find any English-speaking guide, and the hotel knows nothing of ice-axes, tents, etc. -you cannot even get boots greased. The Argentine does not climb. I rather gather that Aconcagua would be the mountain to try. The bases of others seem to be two or three days from here.

Aconcagua lies only a moderate day away. I imagine that if you waited and tried several times, until you chanced on a day of no wind (it cannot be faced so high up with mountain-sickness, too) you could get up. But I should say you must talk Spanish. I can't afford the expense of such a try, and as said, I can't stand the carrying and cold of Dr Hebling's economical way. So I am contenting myself with my photos and notes, and I go on to see Chile on Saturday, 6th March.

By the way, when Dr Hebling went up Aconcagua, he walked for some twenty-four hours without food. Even he could only (above 6000 metres) do some three paces at a time, and could carry nothing. This is rather a rambling answer to yours, but I have just been a long mule expedition.-I am, yours truly,

WALTER LARDEN.

Samuel Turner, Esq.

I let my friends read this letter, but it had the effect of making them afraid of the cold. We started for the Andes, reaching Ponte del Inca the 


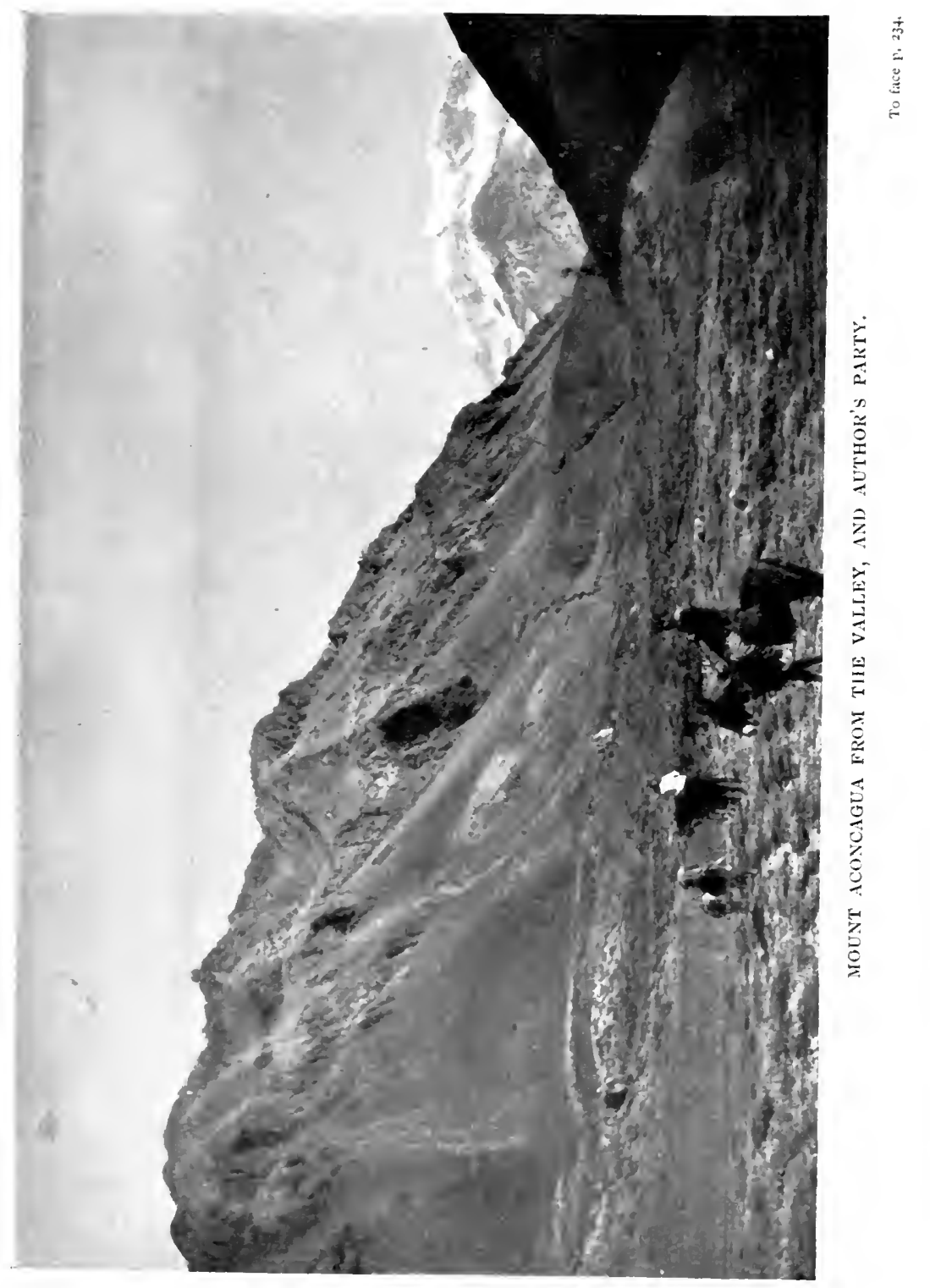




\section{My Attempt on Aconcagua}

following morning. I hurriedly arranged with the hotel proprietor to get us two Spanish peons who knew the way to Aconcagua. Soon after lunch I climbed a mountain about 4000 feet from behind the hotel, which gave me a good look at Aconcagua and the neighbouring peaks. The mountains do not seem to be imposing, because they are all gradual slopes.

I arrived back at the hotel for dinner, and after dinner made arrangements for starting the following morning. Owing to the difficulties and dangers of the cold, and lateness of the season, predicted by the peons, it took me all my time to get my two friends to fulfil their promise to come with me. We were unable to get the all-important sleepingbags, and had to content ourselves with punchos, one of them being made into a sleeping-bag. The provisions supplied us by the hotel proprietor were very poor and extortionate in price. We started for Aconcagua at about eleven o'clock: our party consisted of $\mathrm{Mr}$ Hardman, Mr Robertson, two Spanish peons, myself, and the muleteer, with eleven mules. Five of these mules were pack-mules and we were mounted on six. I could speak about four words of Spanish but Messrs Robertson and Hardman could speak the language very well. I 


\section{My Climbing Adventures}

had hoped to get help from my companions when on the mountain. We crossed the railway bridge over the line, and for the first few miles the road was good, but leaving the railway line we travelled along a mule-path up to a small lake. After this lake there is no recognisable track, and we travelled on the slopes of the mountains and crossed and recrossed the mountain torrents of Orcones and Aconcagua. The edges of these rivers made some interesting but slow going. We had a good view of Aconcagua from the valley Orcones, and only lost the nearer view of its precipices showing its three peaks when we neared its slopes: then Mount Orcones stood out very prominently. We continued our journey on the slopes of Aconcagua, rising higher as we skirted its base. We paused for a rest at the first camp, about I 4,000 feet above sea, but we had left vegetation behind before this.

Soon after we commenced a very steep mulepath, which was very difficult for the mules to climb and awkward riding. We reached the 16,000-feet camp, feeling very sore, and were not long before we unpacked the mules and let the muleteer take them some 15 miles down the valley to find fodder.

In making our camp we had plenty of saddles, 236 


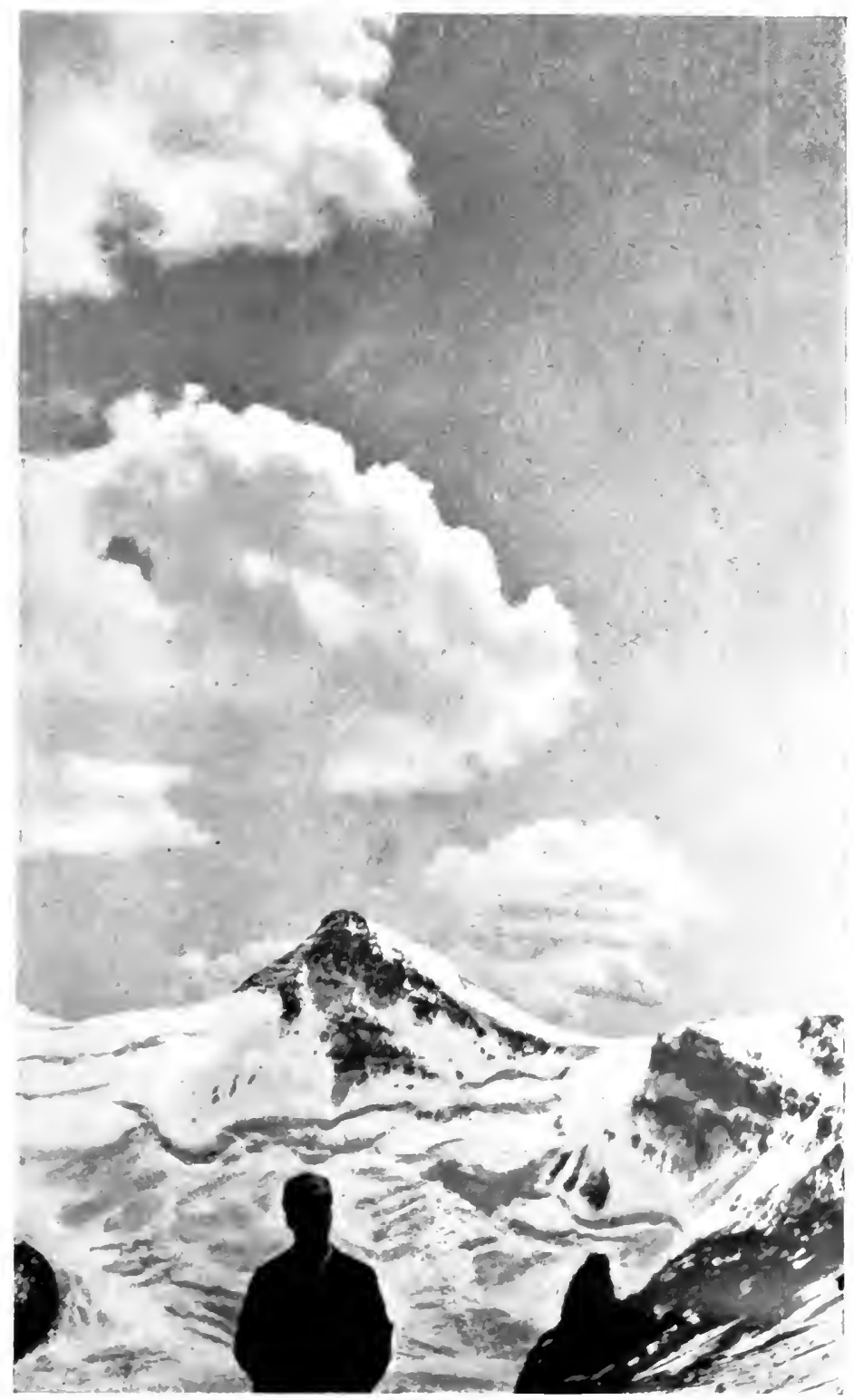

ALTHOR ON ACONCAGCA, AND MOLNT ORCONES IN BACKGROLND.

To face p. 236 . 


\section{My Attempt on Aconcagua}

rugs and sheets to make ourselves comfortable: and besides this, we had the most ideal huge boulder possible to afford us shelter. There was really no need to crowd into the little tent, but three of us tried to sleep in my little tent with saddles placed at the windy side. We made ourselves too warm, and the air inside the little tent became very impure. We were up fairly early the following morning, but later than I had intended, so I made up my mind to go up the gully opposite the camp instead of going up the gradual slope. This was a mistake. At 16,000 feet one must move with care and glide along without jerking the body; but up the gully we climbed. It was a kind of scoria, and one could not walk up it with the flat foot in the necessary way. It was necessary to dig the toes in and take every precaution to prevent one foot slipping down with the powdery scoria while we dug the other foot into it. This route caused us five times as much work as taking the natural ridge shown on the plan drawn for me by Mr. Wedgwood. After 2000 feet of climbing we were glad to halt for a rest and a little lunch; and after lunch we pushed on and gained a ridge in dense clouds and slight snow, which made us camp, owing to the threatening nature of the weather. Our camp was 


\section{My Climbing Adventures}

at an altitude of 18,500 feet, and as the clouds lifted from time to time we had a view of the peaks whose bases we had passed coming up the valley.

The first on the left looking down was Bodega, next Almacen, while the head of the valley was Mount Orcones, over 2I,000 feet, with beautiful cloud-effects, just like the fumes of a volcano. The clouds were evidently very much lower on the Chilian side of Mount Orcones, but the cold wind had driven them up against and up over the summit of the mountain for about 500 feet higher than the summit, afterwards descending to about 18,000 feet, and passing over our camp and down the valley Orcones to join the black snow-laden clouds which had been blown down over the valley between the high mountains, giving us one brief view, which I took advantage of with the camera. The next peak was Tolosa, 20, 140 feet; then the Penetenteries. These views of the peaks were getting less frequent as the day wore on, and as the mist did not clear off the ridge up which we wished to climb, we had no alternative but to stay on the spot where we had camped for the night. After early dinner I turned in and tried to make the peons understand that I wished to be left the furthest away from the wind; but I awoke in the 238 


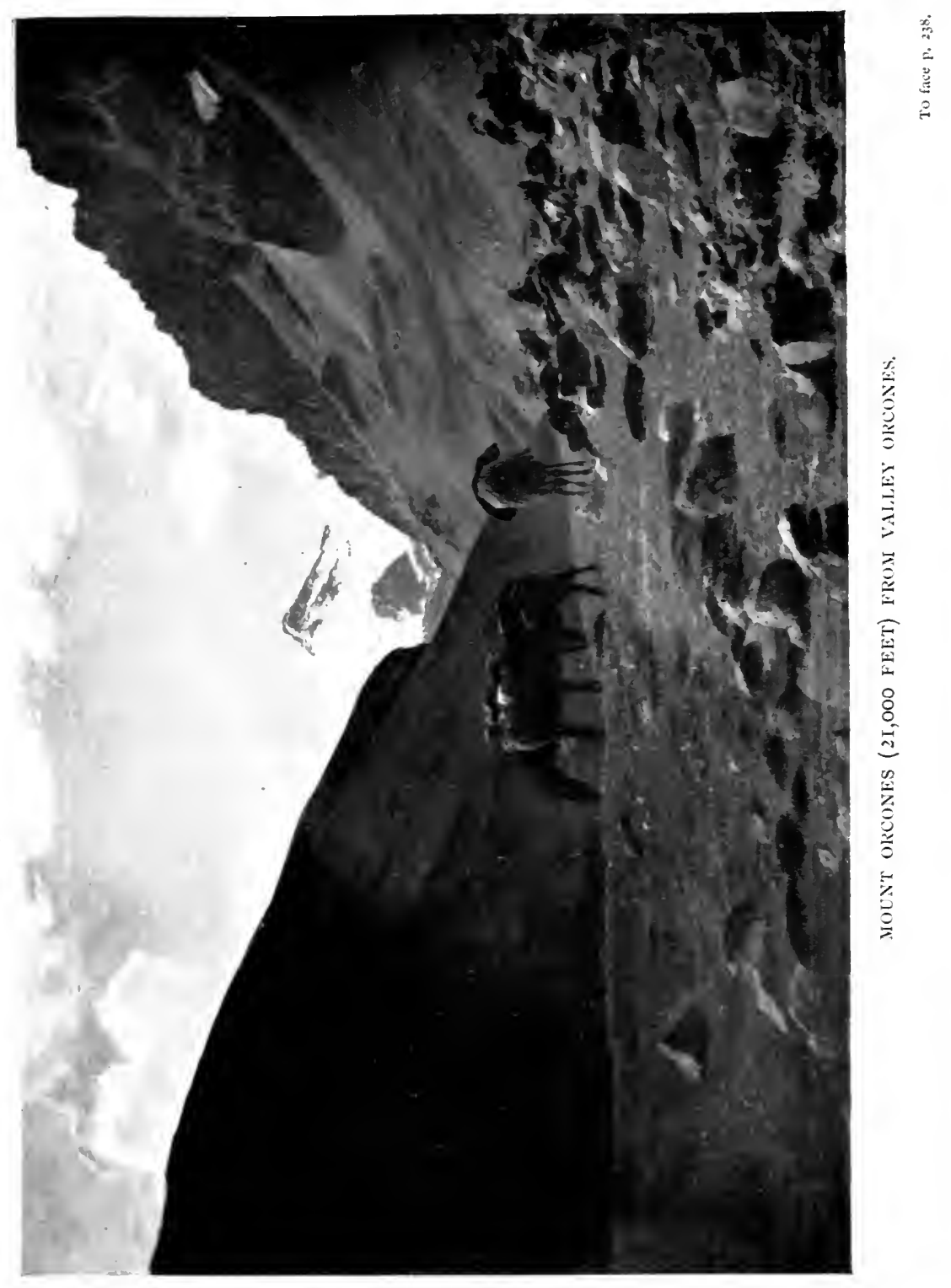




\section{My Attempt on Aconcagua}

middle of the night stupefied by the intense cold, and found that snow was blowing all over me, in between the puncho sleeping-bag and the puncho. I don't know how it was I did not get badly frost-bitten, but as soon as dawn came I crawled out of the tent and moved my limbs about as much as possible. We waited for the mist to lift, but it did not show signs of lifting until the sun was well up; then we pushed on about 2000 feet up the ridge, and finally came to deep, soft snow, which stopped us altogether; and realising that it would be impossible to reach the summit and get back to Buenos Ayres, I decided to return to the camp with all speed. We were none too soon, because it had been snowing heavily on the summits of the mountains and the clouds began to descend with their snow. We sent for the mules, and then made our camp ready for the threatened snowstorm, and were not disappointed. It snowed all night, and when the mules came up the valley the following morning they had to walk through 6 inches or more of snow. The whole of the mules we packed as quickly as possible, and as soon as we reached the bottom of the very steep mule-path to the lower camp, 14,000 feet, we began to hustle the mules along and galloped as fast as we could to 


\section{My Climbing Adventures}

get away from the heavy snowstorm that threatened to envelop us. The mist was very thick and it was very clever of the peons to be able to find their way; but they had to take to the route along the rivers, which at places seemed impossible for any mule to pick a way along. For ten to fifteen minutes at a time the mules by one false step could have tumbled 100 to 200 feet of a sheer drop into a boiling torrent. We were fortunate enough to have only one slight accident. Mr Robertson's mule stumbled and threw him into the stream near the opposite bank; but one of his feet became fast in the stirrup, and the mule dragged him on to the bank with nothing more than a wetting.

We were glad to get back to the Ponte del Inca Hotel, and make ready for our departure. The train brought the news that the winter snow had fallen on the high pass over the Andes, and that traffic would soon have to stop, and we learnt afterwards, the day I was leaving Buenos Ayres, that the snow had set in in real earnest for the winter.

I learnt what I wanted to learn about the equipment and the way to climb Aconcagua, and I was satisfied with the result of my rush up that peak. It was a very expensive six days' journey

$$
240
$$




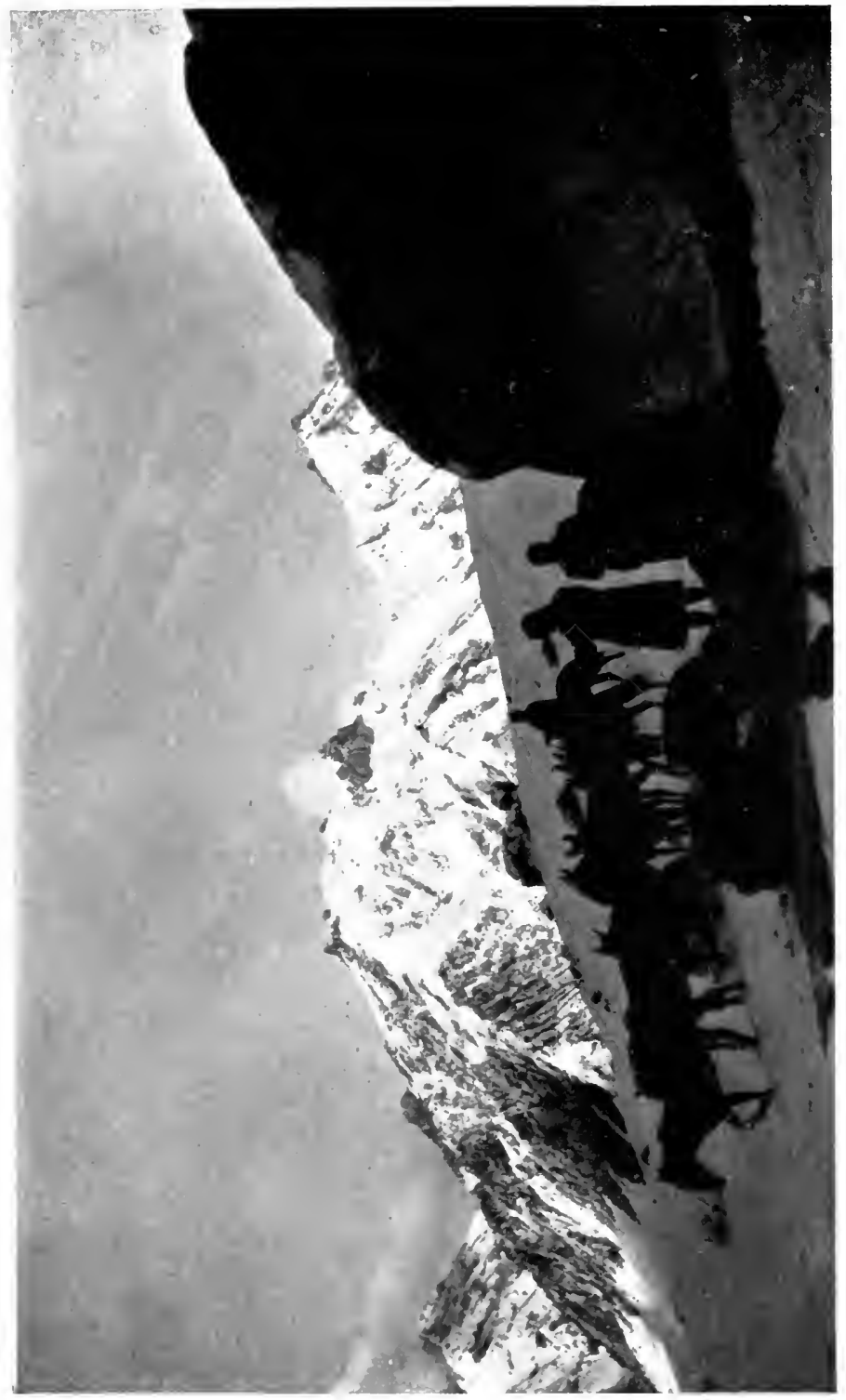

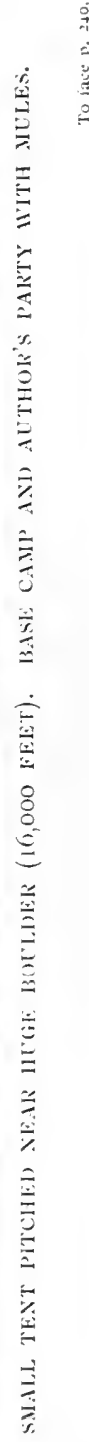





\section{My Attempt on Aconcagua}

for me, costing about $€ 65$; but twice as much would be enough for six weeks' exploration in the Andes, going from Buenos Ayres and back again.

I took a large Kodak, but was glad to exchange it for Mr Hardman's very small camera, which was easy to carry. I believe I have taken the first set of photographs on the slope of Aconcagua, 23,393 feet. It requires four days from Ponte del Inca Hotel to the summit of Aconcagua and back again; that is, providing that the rarefied air has been got used to and one is in splendid condition; but it would constitute a record to be able to do the climb in four days. It is a question, however, if any one would attempt to do the climb in less than fourteen days. I gained the experience that $I$ required on this mountain to be able to climb in the Andes. Before this climb I had no idea of the nature of the country or the equipment necessary. The extreme cold and the inconvenience one suffers are enough to teach one what is necessary for success and comfort. The water-supply is taken from the base of the mountain, by scraping away the very fine grit until about a foot deep you come to water. This water is not only bad, but the fine sand or grit seems to get in the throat and makes it sore. I could not drink or 


\section{My Climbing Adventures}

swallow for two days, and I put it down to the water.

It is a mistake to rush the mountain, because the rarefied air makes it extremely difficult for one. When I took the mountain easily I found this did not trouble me. The geological formation of the mountains up the Valley Orcones is of extreme interest. They are a mixture of sedimentary rock and volcanic rock, pumice scoria all mixed up together.

It looks as though the volcano had not bored its way through the top of the mountain before the earth crumpled and allowed the volcanic rock strata and the sedimentary rock to be mixed up in confusion. To say that these mountains are composed of enormous cinders and ordinary shale and rock piled up without system or design, would be literally correct, although geologically incorrect. Standing on the ridge of Aconcagua and looking at these huge cinders, and afterwards travelling along the valley passing close to them, gives one the impression that it is an inferno of the most crude nature.

The volcanic rocks are all colours, red and sulphur colour mixed with the burnt-out black. The wind-storms not only strip the mountain-tops and ridges of their snow, but the wind is so very 


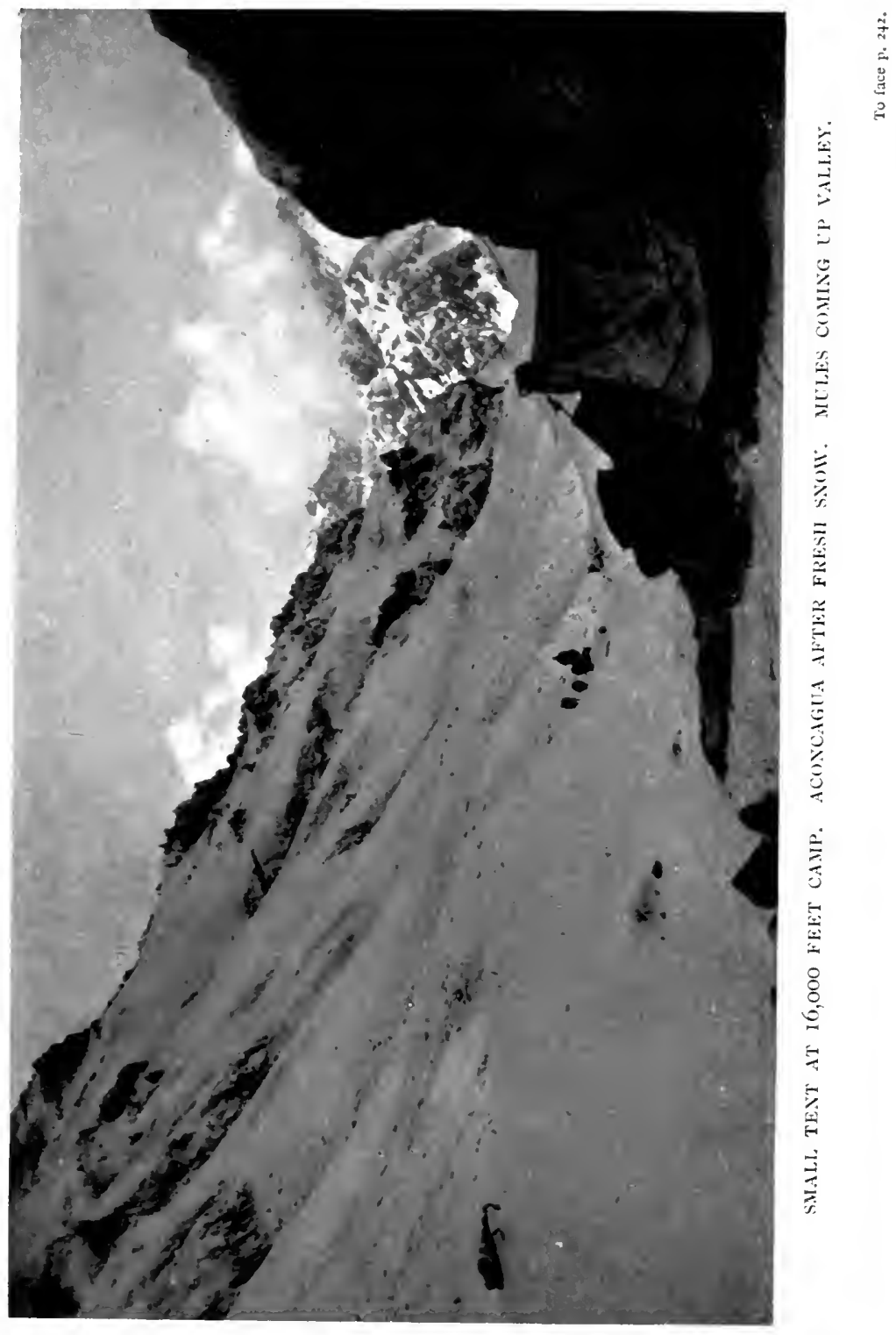




\section{My Attempt on Aconcagua}

strong that fine sand-like scoria must be blown into the air one breathes. This may assist in causing the sore throat one gets very quickly. I came to the conclusion that a party of mountaineers able to spend three weeks of the best time of the year on the climb, provided they are properly equipped and do not rush the mountain, would be able to climb to the highest summit without very much difficulty.

It will be absolutely necessary for any one wishing to climb Aconcagua to spend sufficient time to get fit and used to the air. I am quite satisfied with what I did ; and I question very much whether, at the most favourable time of the season, and given the mountain without deep snow on it and in perfect weather conditions, I should have been able to climb the mountain from Buenos Ayres and back again in six days.

My inside reason tor trying to rush Aconcagua in this impossible short space of time was because I felt that if I was in ordinary condition able to climb this in such a short time, it would help me in my belief that I can climb Mount Everest (29,002 feet): I 7,800 feet was the highest I had attained hitherto; I 6,000 feet was the highest that I had lifted heavy stores or 17,800 feet was the highest I had lifted 


\section{My Climbing Adventures}

stores, about 40 lbs. These were my only tests in rarefied air until I tackled Aconcagua, and on this occasion I was out of condition. The only real training was on board ship, when I skipped a series of 1000, I500, etc., without stopping the rope by my feet. Even this was not severe enough exercise to get oneself fit ; and now on my sea-voyages I skip 2500 to 3000 often, without the rope catching my feet; and on this last journey on the Osterley I skipped $5^{1} 50$ on one occasion and 6696 on another special occasion, to see what I really could do. The 6696 constitutes a world's record skip, and it was skipped in the Red Sea with the purser, his assistant, the third officer and two doctors counting and witnessing the skip, which was without changing the steps, and the step was both feet together, turning the rope myself. I am in this way keeping myself fit for any future climbs I may be able to undertake. Another thing that has given me a great advantage is the fact that I can balance anything on my chin or nose that is at all balanceable-from an envelope to a table or anything up to about $56 \mathrm{lbs}$. in weight. This balance in me has helped me to climb the mountains with as little jerkiness as possible, and to negotiate difficult passages, which would have required many years longer to enable any other 244 


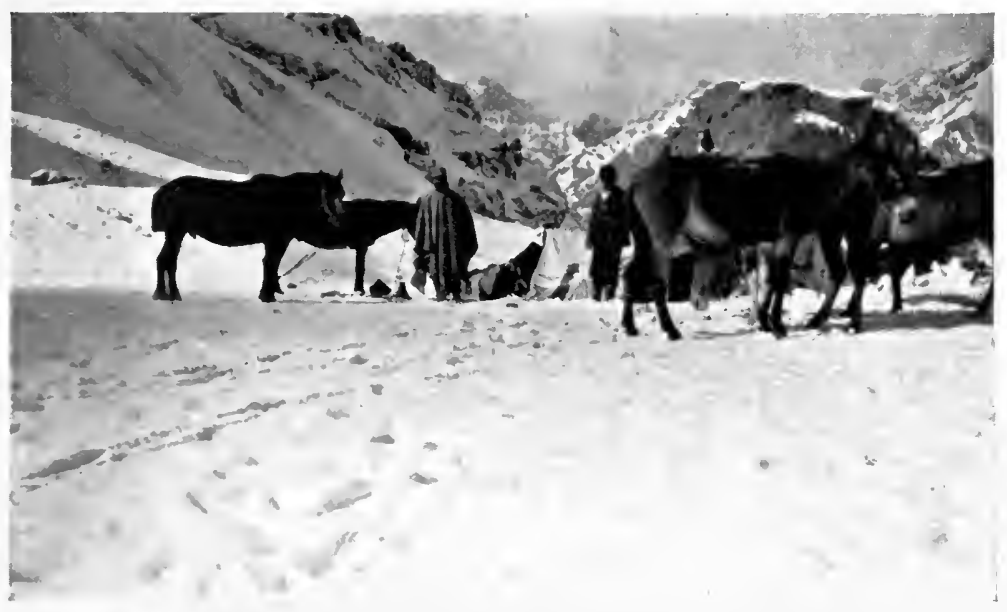

LOADING MLLES I6,000 FEET CAMP AFTER HEAVY SNOWSTORM, ACONCAGUA.

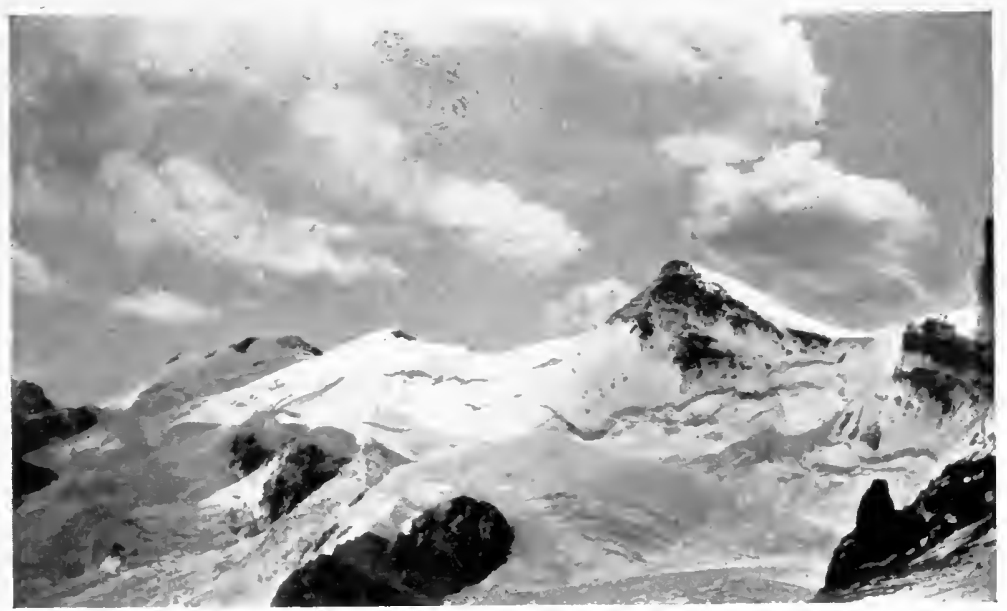

MOUNT ORCONES (2 r,500 FEET) FROM SLOPES OF ACONCAGUA. 


\section{My Attempt on Aconcagua}

climbers to perform these difficult feats with equal degree of safety.

It is and always has been my maxim that the best climber is the man who climbs the most difficult mountain with the least degree of risk. Some men climb a mountain quite safely and others are in danger many times during that climb. My motto is, climb safely, and afterwards climb. I have, however, got into such serious difficulties that it would be impossible for me to persuade my readers that, given favourable conditions, I am one of the most careful of living climbers; at the same time I must confess that when on several occasions I have had very much opposition on an expedition, I have made up my mind that I would rather risk my life than give up the attempt; and in this way I succeeded in getting the three companions of mine to go over Mount Cook, and encounter the most serious difficulties, in the shape of ice-glazed rocks, that it has been my lot to encounter. I believe that having taken risks in the most unfavourable time, I know the mountains in their most fierce moods and weather conditions; and in this respect they present to me a more vivid and impressive picture than if I had climbed under the usual favourable circumstances. 


\section{My Climbing Adventures}

The mountaineer who does not know mountains in the winter, the off-season, and the storm, is like the sailor who does not know the sea in a storm. It takes all kinds of experiences to make the mountaineer's career; and I am pleased to say that I am more fit, stronger and healthier to-day than I have ever been in my life; with an exceptionally good pulse and heart, according to the doctors who examined me in the Red Sea, after skipping the world's record skip. I have a lump on one of my ribs through wriggling up a crack on a precipice, another lump on the occiput of my head from a piece of a rock-avalanche off Mount Cook, and rather weak eyes through being snow-blind on three occasions. I have five times had the skin off my ears, neck, and face ; but with the exception of these minor things, I have gained everything and lost nothing in my encounter with the mountains. I hold the conviction that the years gained by the lengthening of the days of climbers, if they could be totalled up, would far outweigh the number of days the climbers who have perished on the mountains would have lost. Out of, say, 40,000 climbers in Europe, there are, say, 2 per cent. fatalities during their lifetime, but the 2 per cent. means perhaps ten, twenty, or thirty years lost to these climbers who 246 


\section{My Attempt on Aconcagua}

were killed. It only requires the remaining 98 per cent. of climbers to gain one-third of a year each in length of days, and the total of life lost is wiped out.

It is only natural that a climber will lengthen his years at least by five; and if so, it means an enormous gain of life to the mountaineers in general. I have heard it argued that golf has prolonged a man of sixty's life by five years. One should just take a look at the Royal Geographical Society members, or the Alpine Club members, when they are gathered together, and consider the length of years many of them attain. The Alps have been the givers of peace, joy, health and length of years to many climbers. You go full of cobwebs, worried by the world's rush and scurry for wealth, a physical and mental wreck, and come back full of vitality and strength. Amongst the mountains the climber seems as free as Nature itself. The rush of the mountain torrent into the glass-like lake in its calm repose between the mountain; the pure snowfields and blue majestic glaciers which have crawled from the mysterious summits of the mountains; the ever-changing picture between the morning tint and evening glow and afterglow, which form the most beautiful sky study; 


\section{My Climbing Adventures}

the impressions of the storm while one is conquering some great mountain; the fascination of difficulties overcome, amidst such almost everlasting beauties; are things lovely enough to attract the most indifferent and unpoetical of men. The triumph over Nature, the training of man's faculties of endurance, judgment, skill, resource, patience, and many other qualities, enable a man to appreciate life, the world and its beautiful wild and remote parts, so that life becomes fuller and more interesting, while the ever-changing scenes are stored up in the mind as picture galleries, which become a part of the climber's nature.

The unknown or little-known peaks, passes and glaciers are the fascinating and entrancing world which draws the soul of the explorer and climber even against his own will; but the climber and explorer realise such an entire change from the ordinary world as nobody could realise, unless they could be transplanted on to the mountains of the moon or a distant planet. Who shall dare to say that there is nothing in climbing and exploration? If they have not indulged in the craft, they are just as presumptuous as is the man who cannot see what So-and-so has to make him happy, when all his surroundings are against happiness, from the critic's 248 


\section{My Attempt on Aconcagua}

standpoint. Climbing is not a lazy man's hobby, and from the point of the hard work it entails, a large percentage would criticise it, if not condemn it.

For the man who has an appetite for hard work, and who believes it is better to wear out than to rust out, climbing is the one hobby he should take up. It trains him to stand the strain of any tight corner in life that he may be unfortunately placed in, and it enables him to overcome difficulties-one of the best gifts this world can give, or the man can wish for. My circumstances are against much climbing, or I would have climbed ten times as much as I have. 


\title{
CHAPTER XIII
}

\author{
CONCLUSION
}

W OUNTAINEERING conveys many differ1 ent meanings, and is probably one of the most misunderstood hobbies or crafts.

This is not surprising, because it has not yet been settled at what height the hill finishes and the mountain begins. There are so-called mountains in the British Isles about 2000 feet above sea-level; while there are hills in India three times that height.

If the reader's knowledge, gained by books, photographs, or by travelling, is extensive, then mountaineering means more or less adventure, according to the country and system of mountains he is thinking about.

One reader imagines that the climber cuts steps up a vertical ice-wall; another reader imagines that climbing is only walking up gradual slopes-and both are wrong. Many people who have unfortunately been confined to the British Isles, or their own native country district, will tell 250 


\section{Conclusion}

of their mountain adventure, on what is called a mountain; but if it was investigated by a mountaineer who has climbed dangerous mountains of the world, the adventure would seem to have been more the outcome of nerves or a kind of blunt faculty, than of real mountain difficulties.

I have listened to an exciting tale, of how, in the Cumberland hills, the retailer of the story walked across a narrow strip, only 3 yards wide, between two mountains, and there were hundreds of feet of a drop on either side!

I have no doubt that, to this climber, that feat was more than equal to an expert climber walking along a I-yard corniced snow ridge with thousands of feet of a drop on either side.

It does not follow that it is because the novice has no pluck that he gets down on all fours halfway across the 3-yard-wide ridge; it may be for want of pluck in many cases, but there is another factor that will produce this sense of danger. $\mathrm{He}$ may have only a blunt faculty instead of the climber's very fine sensitive faculty; and the 3 yards-broad ledge may seem narrower to the novice climber than the 3 -feet ledge to the climber. Let me illustrate more fully what I mean by fine, wellfocussed faculty. 


\section{My Climbing Adventures}

A dog is chasing a cat, the same size as itself, and to escape, the cat runs along the top of the 2inch-wide railings. The dog tries to follow, but tumbles off. The dog tumbles off because its faculty is not so fine or sensitive as the cat's. Both have different natures, and men are just as widely different.

As a matter of fact, the expert climber considers himself quite safe if he has a 2-inch hand-grip or 6 inches foot-hold; that is, assuming the rock is good and sound. He would only be concerned if on shaly or limestone rock.

The expert mountaineer never feels in danger although he has only jumped the crevasse, or from one ledge of the precipice to the other, by the smallest margin. Men must be born with this fine sensitive faculty, or they cannot become serious mountaineers without considerable risk. Blondin had this fine faculty, and it made the rope across Niagara Rapids broad, and just as safe as the $3^{--}$ feet-broad ridge on a high mountain to the expert climber.

Some people would practise as long as Blondin, and not even be able to walk the tight rope at all.

Another illustration of a well-focussed faculty is 252 


\section{Conclusion}

shown in the equilibrist being able to balance anything.

On this question I can give my own experience as to how it is a gift, being myself an equilibrist.

I have had this fineness of faculty or wellfocussed balance since I was very young, and while other boys crawled on hands and knees I have run at full speed on a parapet 2 feet wide with 200 feet of a drop on one side. I found the balancing faculty so well developed that with practice I found I was able to balance as small a piece of paper as it is possible for any man to balance.

I can also balance any balanceable piece of furniture up to $60 \mathrm{lbs}$. weight. This same faculty enables me to jump and turn the skipping-rope round over my head and under my feet three times before they touch the ground, also skip 200 times in a minute; while this faculty, combined with strength, has enabled me to skip 6696 skips in forty minutes without stopping the rope, as shown by the following copy of certificate :-

$$
\begin{gathered}
\text { R.M.S. Osterley (at Sea). } \\
\text { 26/10/10. }
\end{gathered}
$$

This is to certify that Mr Samuel Turner of London, a passenger per this ship from Australia to London, has this day (in the Red Sea) skipped with both feet together, and without stopping the rope, 6696 times.

$$
\text { Q } 253
$$




\section{My Climbing Adventures}

The skip took forty minutes and was witnessed by the following persons, who counted and scored as the skip progressed :-

$$
\begin{aligned}
& \text { L. V. James, 3rd Officer. } \\
& \text { R. Sydney Helley, } 5 \text { th Officer. } \\
& \text { J. Sparks, Purser. }
\end{aligned}
$$

I was present during the whole of the skip by $\mathrm{Mr}$ Turner, examined him immediately afterwards, and found him by no means exhausted and, in my opinion, capable of continuing the skip for a considerable time longer.

Arthur Drysdale, M.B.

This feat required considerable balance, as the ship rolled.

The fine, well - focussed sensitive faculty and exceptional strength and endurance rarely go together. One is used to seeing the sensitive faculty in a nervous person; and that sensitiveness is often looked upon as timidity, and a drawback, while in the strong-willed man it is a great gift.

The climber is more or less sensitive to his environments, according to this faculty. It enables him to feel the slightest give of the rock or ice, hand- or foot-holds.

All these gifts and developments in the athlete are at a serious discount if the climber is not a true-born mountaineer-one who loves the mountains, because they allow the rugged nature of 

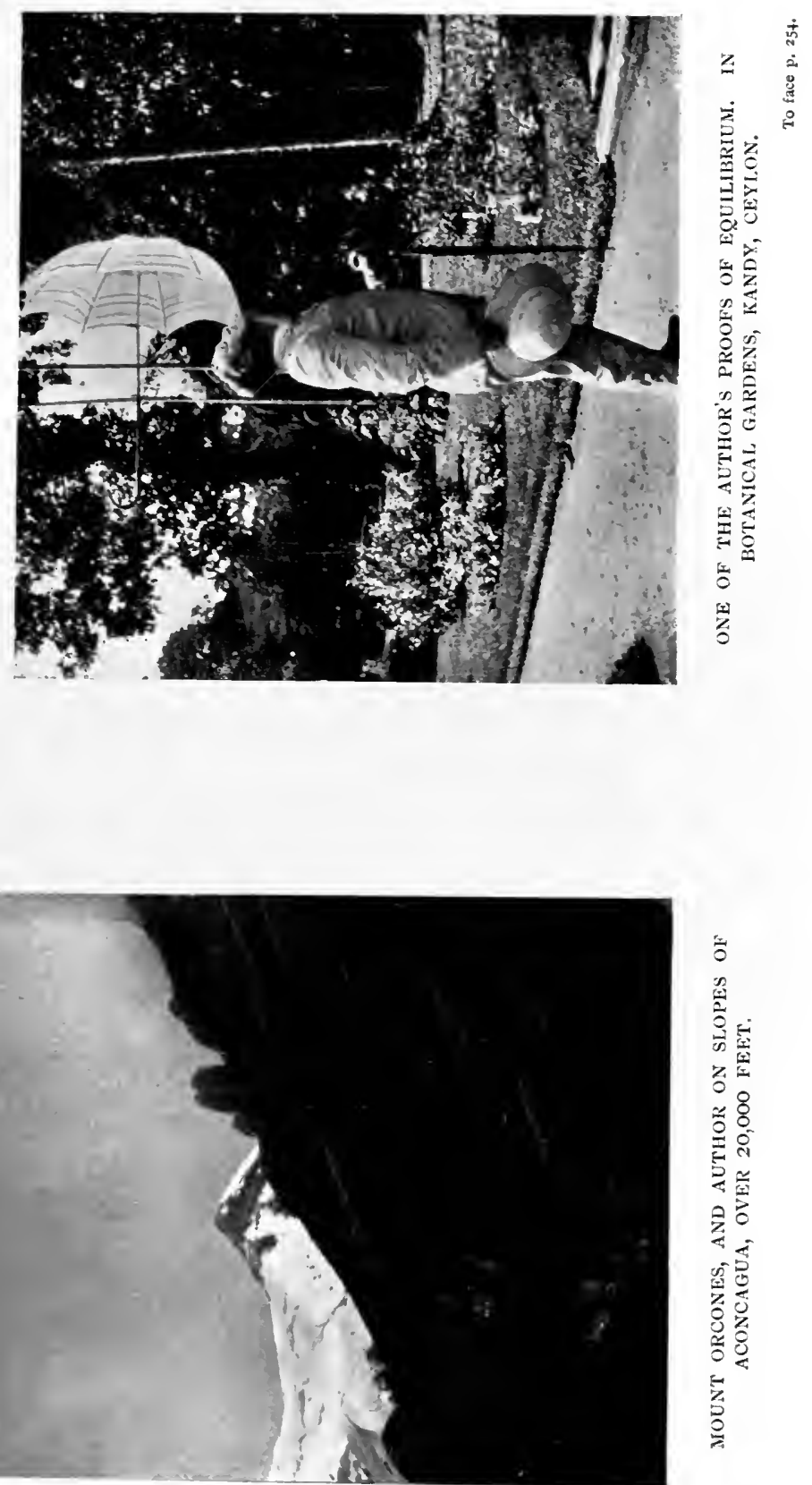

ว

整

究

资

$\approx 8$

잉

돈

응

4

की

这

응

5

穹 



\section{Conclusion}

the man to hurl itself against Nature's difficulties without restraint; to feed on conquests; with intense zeal and enthusiasm comes that spark of genius akin to madness, making one climb like a man inspired. With this zeal man will get through adventures and have escapes that ordinary climbers would succumb to.

It was this zeal that made me cross Siberia in winter, and made me plod on against all opposition ; but I was eventually rewarded by the Russian Imperial Geographical Society's medal, for discovering new mountains, and being the only explorer to go into the Altai Mountains in winter. This was awarded after lecturing to them in $\mathrm{St}$ Petersburg.

I found on Aconcagua that my low pulse helped me considerably. My pulse is 60 to 62 at sealevel, and was 70 at 10,000 feet on Mont Blanc. I have found I could lift heavy stones at 17,800 feet, and have walked with ease at 20,000 feet, and struggled for 500 feet in deep snow at a height of from 20,000 feet to 20,500 feet. The low pulse is the most important gift for the exceptional high climb. The pulse increases by compound interest 60 at sea-level to, say, 70 at ro, 000 feet, but 70 at sea-level is 98 at 10,000 255 


\section{My Climbing Adventures}

feet, according to one test I made on Mont Blanc.

Having gone in for all kinds of athletic sports, I have found that being a life-teetotaller and nonsmoker has helped me considerably. The mountaineer who does not smoke or drink, and has never done so, will have a much better chance of success.

It is the mental as well as the pulse condition produced by the exertion in rarefied air which tells. There is no test that a man can climb at a great height except by the actual experience itselfmal-de-montagne is as uncertain as mal-de-mer, both affect the least likely person, and depend upon the conditions of body and mind.

The only indication that a man is fitted for climbs in the greatest altitudes is the low pulse. The reason why I have dealt at length with the different qualities necessary for an exceptional climber is because, in the first case, I wish to let would-be climbers and explorers know what it is necessary for them to be before they can hope to be able to climb the highest mountains, or even the Swiss Alps, with any degree of safety.

I have another object in mentioning my skipping power and power of balance and pulse, together 256 


\section{Conclusion}

with my rushes up the different mountains; and this object is that I wish some day to attempt Mount Everest; and the qualifications set forth in this book may be the means of getting me in touch with some one eager to try conclusions with Mount Everest.

When I lectured to the Royal Scottish Geographical Society at Edinburgh, the President promised me the Society's gold medal if I ever succeeded in climbing Mount Everest; and I hope to have a try for it one of these days.

My own opinion of the five highest mountains in the world is, that four out of the five are absolutely impossible climbs to man who lives near the sea-level; but that they may be climbed by men who have lived at great heights and become acclimatised.

It has been unanimously agreed by the Duc d'Abruzzi, and the leading Himalayan explorers and climbers, that $\mathrm{K}_{2}$ and its neighbouring peaks are impossible and unclimbable.

The step-cutting necessary at 25,000 to 26,000 feet on these mountains, as well as the mountain difficulties, make them impossible. They rise I 1,000 to 1 2,000 feet from the glacier, with very steep ice slopes. 


\section{My Climbing Adventures}

Mount Bride, on which the Duc d'Abruzzi has climbed the world's record, 25,600 feet, without reaching the summit, is the only one possible to climb.

There is a wide difference between the gradual slopes of Mount Everest (29,002 feet) and those of $K_{2}$, the next highest peak, because $K_{2}$ has a very steep ice-slope nearing its summit, and the summit itself seems to present overhanging precipices, a very difficult climb, even if there was no question of rarefied air.

I consider the climbing of Mount Everest or $\mathrm{K}_{2}$ a greater feat than getting to the North or South Pole; and probably for half a century or more after both Poles have been properly reached, the $\mathrm{K} 2$ group of the world's highest peaks will still be unconquered.

Two successive seasons in the neighbourhood of Mount Everest, as high as possible, in the winter, would help the climbers the second year; and becoming acclimatised would be the next most important advantage to a low pulse. After this, the well-balanced men, with well-focussed faculty, would climb with the least jerkiness, and so help the pulse.

The superstition of the coolies was overcome in the Duc d'Abruzzi's expedition, and in the $\mathrm{K}_{2}$ 258 


\section{Conclusion}

district the coolies are reported to be good. That is good progress, because in times past well-organised expeditions have been spoilt through superstitious coolies. Strong will-power and mental fitness of the climber is necessary to keep awake in the rarefied air. The nervous and fidgety climber, who will not go to sleep properly at night in the tent, will want to sleep on the most dangerous parts of the mountain the following day, and very often the rarefied air is blamed for nothing more than want of sleep and a state of tiredness caused by thinking about the mountain all night instead of sleeping.

I consider it just as foolhardy for a Swiss climber, without any experience of exploration, to tackle the Himalayas, as it is for a novice to attempt the Matterhorn.

Climbing trees and boulders will strengthen the arms and legs and give the beginner practice for the acrobatic rock-climbs; and after becoming proficient in the Cumberland crags, he must have the best climbing in Switzerland. After that the Caucasus or, more difficult still, the Southern Alps of New Zealand, the Siberian Altai or the Chinese Turkestan Mountains, or the low easy climbs of the Himalayas. After experiencing these mountains, the great giants of the world may be attempted. 


\section{My Climbing Adventures}

There are, no doubt, many enthusiastic climbers, capable of great things on the highest mountains in the world, who cannot go beyond the Swiss Alps or the more easily climbed Rockies : and it is true that occasionally a middle-aged man or woman, with plenty of money, engaging mule-guides and mules, may get up a great height on the Himalayas and those mountains which are easiest to walk up; but generally the present explorers and climbers, who have become known to the public, are the successful few who continue to climb because of special skill and ability which has enabled them to cheat the mountain of another victim. I quite believe that the present body of Himalayan climbers and explorers would be very hard to beat; but I am confident that special men can be trained, if they have the qualities mentioned by me, who would, after a series of attempts, produce one or two of the most exceptional gifted climbers who would reach the summit.

There has been some very fine high climbing done in the Himalayas, but there is no mountain system in the world where one can find mountains on which it is so easy to get to a great altitude, say, 22,000 to 23,000 feet. The mules can walk 18,000 to 20,000 feet in some parts. A mountain, the 260 


\section{Conclusion}

height of 10,000 to 12,000 feet in the Swiss or New Zealand Alps, may be a physical impossibility to the man or woman who gets 22,000 to 23,000 feet high on the Himalayas; but although a great deal can be done by money and time, and great heights can be gained by the ordinary mountaineers, most of the climbing, like the record climb of the Duc d'Abruzzi, has been accomplished by the very best mountaineers.

No high climb is taken at more than 2000 to 3000 feet a day. My climb in the Siberian Alps, I 7,800 feet, and 20,500 feet up Aconcagua (except the last 500 feet in deep snow), were both very much easier than the Mount Cook climb, I2,349 feet; and there is more mountain-climbing on Mount Cook from the valley to the summit than there is on almost any except the very highest Himalayan mountains, and quite 3000 feet more than on Aconcagua.

This shows that height is nothing to go by in measuring the difficulty of a climb. Man has almost conquered the earth, and at the present rate of progress, in the near future, the only unconquered parts of the world will be the apparently inaccessible mountains.

The progress of man, in his ability to stand 261 


\section{My Climbing Adventures}

rarefied air, and the heights he has attained of recent years on the highest mountains in the world, is evidence, to my mind, that all the earth's mountains will be conquered by man in the not distant future. 
A P P E N D I X 



\section{APPENDIX}

\section{SIBERIAN AND SOUTH AMERICAN OUTFITS FOR CLIMBING}

THE outfit and equipment for climbing in the Andes and the Altai are difficult to think out, and as far as the expedition to Aconcagua was concerned, I knew that it would be the merest chance if I succeeded in reaching the summit ; chiefly for want of time, but also for want of a proper outfit; and after careful study and consultation with a climbing friend, I give below the list of things absolutely necessary for the comfort which will lead to success.

I engaged nine mules and a muleteer from the hotel proprietor at the Hotel Ponte del Inca, and I also bought punchos, etc., for the peons. My expenses from Buenos Ayres came to about $£ 60$, including the railway fare from Buenos Ayres.

On the list I mark B. A., after those articles to be purchased more conveniently in Buenos Ayres.

It will not be advisable to rely upon getting mules at Ponte del Inca, because if there are many tourists, the hotel proprietor will be unable to spare them.

All previous climbers have got mules from Mendoza, and taken them to Ponte del Inca. The muleteer will drive them from Mendoza, but it would want a few days for the journey.

It is not advisable to rely upon getting mules at Ponte del Inca, because the mules that are there are not 265 


\section{My Climbing Adventures}

sufficient even for the short excursions which tourists take from the hotel.

We were able to get mules at the hotel, because the tourist season had finished and it was late autumn, but Fitzgerald's party and other parties had brought their mules up from Mendoza.

The Transandine Railway Agent in Buenos Ayres can supply the name of the best mule-owner.

The anthropologist and geologist, Dr Lehmann Nietzchie and Professor Shroder of the La Plata Museum, La Plata, would very probably join an expedition.

Dr Hebling is the leading Andean mountaineer at the present day.

The British Consul in Buenos Ayres is very obliging, and should be visited by mountaineers intending climbing in the Andes.

No doubt the address of Dr Hebling could be received from the British Consul.

It is a very good plan to have boxes made that will fit on each side of the mule, and have the contents written down and the boxes numbered.

The hotel proprietor at Ponte del Inca will arrange for two peons who know Aconcagua and the surrounding district, and will be able to lead any party to a height from which they will be able to climb the mountain.

Riding breeches are necessary, and the climber must be able to ride fairly well, as a mule goes over very awkward parts, along the precipitous river-banks.

There is no convenience for mountaineers at the hotel, as a mountaineering expedition to the Andes is a rare occurrence.

It is necessary to speak Spanish or take an interpreter. I found myself seriously handicapped in this respect. 266 


\section{Appendix}

One or two English railway officers on the railway would be willing to join an expedition, but with the exception of the peons, it is not wise to rely upon any one else.

One of the main difficulties is the scarcity of good water at the 16,000 -feet camp.

It would almost pay to take all the Vichy Water from England, instead of taking it from the ship. It could be taken in leather water-bottles. We had to take water from the base of the mountain by digging a hole in the loose gravel. It must have been full of grit, which was very probably the reason why it became difficult to swallow anything, the grit in the water irritating the throat.

A large tent for the 16,000 -feet camp is also absolutely necessary, although there is a good boulder which affords splendid shelter. It is not safe without a large tent.

Climbing Equipment, Foods, etc., for Andes

2 Whymper tents, 6 by 3 .

I small light tent.

(N.B.-Tent-pegs of iron to be got for this.)

2 mackintosh sheets, 7 by 4 .

4 ice-axes-2 ice-axe holders.

I or 2 silk Alpine ropes (Buckingham's).

3 sleeping-bags, eiderdown or tuckett, partly of mackintosh, lined felt, but better with Jaeger woollen material.

I pair binoculars.

4 pairs goggles.

4 pairs gloves.

2 lanterns. 


\section{My Climbing Adventures}

2 indiarubber folding cups.

Alpine boots (Dowie \& Marshall's).

3 aluminium quart bottles for methylated spirits.

I aluminium quart bottle for tea.

Either I aluminium stove, or I Primus, or I Rob Roy cooking apparatus.

I leather bottle.

Aluminium canteen.

4 doz. packets solidified methylated spirits.

Ordinary methylated spirits.

Candles, matches (B.A.).

Oil-silk bags for food.

Celluloid boxes for butter.

Food

Calculated for four people for three weeks. Per day -2 soup tablets (Lazenby).

$I_{2}^{\frac{1}{2}}$ Army rations.

$2 \frac{1}{4} \mathrm{lb}$. tins of jam.

$\frac{1}{2} \mathrm{lb}$. tin sardines.

$\frac{1}{2} \mathrm{lb}$. peas or beans.

3 doz. Lazenby's tablets, oxtail, pea, maggi and tomato. I doz. self-cooking soups (tomato and pea).

Saccharine tablets.

4 doz. $\frac{1}{4}$ lb. mixed jams, etc. (2 doz. black-currant,

I doz. strawberry and I doz, marmalade).

3 bottles essence of peppermint.

3 bottles acid drops.

2 I lb. tins assorted chocolates (Rowntree's).

I lb. plain chocolate.

4 lbs. sultanas

$27 \mathrm{lb}$. tins of biscuits (about $60 \mathrm{lbs}$. biscuits in all) (B.A.). 


\section{Appendix}

12 tins apricots.

6 tins pears.

Soap ; rice ; beans (B.A.)

6 small legs mutton (B.A.)

2 joints beef (B.A.).

Syrup (B.A.).

2 lbs. cocoa ; I lb. coffee ; I lb. tea (B.A.).

6 (I-lb.) tins condensed milk.

I case Vichy water, I case Perrier (on ship).

Oatmeal (B.A.) ; 6 doz. eggs (B.A.).

12 tins sardines.

Membrille (B.A.).

2 doz. oranges ; I doz. lemons; 5 lbs. apples (B.A.).

3 lbs. prunes.

Fresh peaches and 12 lbs. grapes (Mendoza).

Spare tins.

12 tins tongue.

4 pots Liebig; ro lbs. loaf-cube sugar.

Glycerine lozenges, black-currant lozenges.

Potash pellets.

Gruyère cheese ; butter (B.A.).

Rum, maté (B.A.).

Milk biscuits (B.A.).

Clothes

Jaeger suit, long stockings, extra waistcoat.

White canvas cap, storm-cap (cross-woven cloth).

2 caps for sleeping in.

Silk handkerchiefs.

LUGGAGE

I large-size canvas bag, locking, $3 \mathrm{ft}$. high at least.

I of another kind, sportsman's bag, holdall.

I bag, I trunk.

R

269 


\section{My Climbing Adventures}

\section{MisCELIANEOUS}

2 tubes Lanoline; 2 tins Dubbin; 2 prs. laces.

2 lbs. wool for cold feet while sleeping; I tin Eno's Fruit Salt.

2 doz. spools films and No. I Kodak for high altitudes larger for low altitudes.

Thermometer aneroid (Watkins'), boiling-point thermometer; small prismatic compass. Alpine nails and hammer; 2 light rucksacks. Fitzgerald's Map.

Goertz lens fitted on No. 3 folded pocket Kodak, and rolls of films packed in water-tight tins.

\section{SIBERIAN OUTFIT, ETC.}

(Permission has to be secured in London to take firearms into Russia.)

2 sheets Russian 40-verst map at Stanford's, Long Acre, London, W.C., 3 roubles.

(I had no Customs duty to pay, but it might cost $£$ IO to $£ \mathrm{I} 2$, according to the bulk of luggage and eatables.)

Conveyance for two persons and luggage on two sledges or two pack-horses and two riding horses, 600 versts, 300 roubles.

Hunters and six horses for ten days (hunters, I rouble per day; horses, 50 kopecks per day), 50 roubles.

Interpreter's pay, 5 roubles per day.

Particulars of boat journey from London to St Petersburg or Riga can be obtained from Messrs Tegner, Price \& Co., 107 Fenchurch Street, London, E.C., and W. E. Bolt \& Co., I East India Avenue, London, E.C. The shipper will procure the passport. 


\section{Appendix}

The whole journey would cost, at the outside, between I600 to 1700 roubles, or about $£ 168$ to $£ 178$.

The expenses for the climbing and exploring outfit are not dealt with.

If bear, wild sheep, or ibex shooting is contemplated, the following additional equipment is necessary :-

One 450 bore Cordite Express rifle, weighing to or 11 lbs., for large animals.

A gun is required for small game.

It is necessary to have a sling affixed to the gun, as you have to ride with it on your shoulders. I took a pistol, but did not find any use for it.

A Zeiss binocular will be found useful.

Camera.-I took a Goertz lens fitted on a No. 3 folding pocket Kodak, and 24 rolls of films, packed in watertight tins.

The air is clearer than in Switzerland, and a snapshot or short-time exposure is generally sufficient.

Clothing should be similar to the climbing outfit described in Hints to Travellers, published by the Royal Geographical Society, London.

Dark spectacles are necessary to prevent snowblindness.

You require valenkis (felt top-boots) and goloshes (high-topped), which can be bought in Moscow.

A compass is not very necessary on the road, as there are good land-marks, but you require one for the mountains.

I should recommend a small green canvas Mummery tent for the mountains, and a larger canvas explorer's tent for the camp at the base of the mountains. The largest should weigh about $30 \mathrm{lbs}$., and accommodate two men; 


\section{My Climbing Adventures}

the small one 12 lbs., and also be suitable for two men to crawl in.

All luggage should be taken separately and not in boxes, or you will almost certainly be taxed for the weight of the boxes as well as the tents. Benjamin Edginton, Duke Street, London Bridge, makes a suitable tent.

An interpreter is necessary, unless the traveller knows Russian, and even then he will want a companion.

In selecting a hunter I recommend one Siberian hunter, who can speak Kalmuck, and one Kalmuck, who is generally a good hunter and knows the district better than the Siberian.

The hunter's pay includes food, which they find themselves, also fodder for their horses.

You will be able to shoot what fowl or meat you require. See that your hunter and Kalmuck take plenty of food, or they will eat yours and you may run short.

A pony will carry about $1 \frac{1}{2}$ cwts., but this must be reduced to I cwt. on the mountain slopes. To get along quickly you commence hustling the peasants immediately you get out of your sledge or conveyance, and do not sit down to tea until you see them on their way for horses and sledge. One word "skorey," is very handy, as it means hurry.

You stop on the road at wooden huts, which in winter are heated by a stove and are very warm. The peasant is very sociable, and willingly brings out the best he has, leaving the price to you.

Plenty of Keating's Powder is a necessity.

The tarakan is the insect that will trouble you most, but this insect is not caused by dirt, as the post-stations are kept clean.

The pleasure of Siberian sledging or travelling by 


\section{Appendix}

droshky depends upon the condition of the roads. The country interests you, and you are able to look about with freedom. You can stop the bells if you object to the noise they make. You have to take pack-horses and saddled ponies at times, and this is very slow travelling-probably not more than 30 miles a day-while on a droshky you may cover 75 miles a day.

Beyond Biysk you must arrange for your own food, etc. Take methylated spirits in liquid and a good methylated spirit-lamp and stove, also blocks of spiritine, which are very handy, as they go in your pockets.

June or July are the two best months for the mountains. If you start on the Ist of May, the following programme can be carried out :-

Leave London, Ist May; arrive St Petersburg, 6th May.

Leave St Petersburg (evening), 7th May ; arrive Moscow (morning), 8th May.

Arrive Novo-Nicolaëvsk, 14th May; leave NovoNicolaëvsk (by steamer), 16th May.

Arrive Biysk, 20th May; leave Biysk, 23rd May.

Arrive Katunda, 26th May; leave Katunda, 28th May. Arrive Akkem valley, 29th May; base of peaks, 3oth May.

Fourteen days' hunting and climbing, I 3 th June. Arrive back to Katunda, 15 th June. Arrive back Biysk, I8th June; leave Biysk, 2oth June. Arrive Novo-Nicolaëvsk, 24th June. Leave Novo-Nicolaëvsk, 25th June. Arrive Moscow, 3ist June; London, 7th July.

A day would have to be spent at Biysk in making 273 


\section{My Climbing Adventures}

purchases. The return journey down the river with the fast current only takes two and a half days.

To go by boat from London to Riga and back is about $£ 14$ cheaper return, and there is no worry with the frontier Customs-House officers. I was helped by the Russian Ambassador, London; the British Ambassador, St Petersburg; the Minister of Ways and Communications; Prince Sherbatoff, the President of the Russian Imperial Geographical Society; Professor Sapozhnikoff of Tomsk University, and the Governor of Tomsk.

It is wise to make the acquaintance of the police at Barnaul and Biysk, and let them know where you are going.

Introductions are unnecessary.

The best hotels are the Hotel de Europe, St Petersburg; Slaviansky Bazar, Moscow. There is only one at Novo-Nicolaëvsk.

You can procure guides at the hotels at St Petersburg and Moseow to show you the tours.

If you go in winter, you require particularly thin underclothing, and very thick overcoats and furs, as the temperature, inside the trains and houses is very warm, whereas outside it is very cold. In camp you require very warm underclothing; it cannot be too warm, as you have not the slightest idea of what a winter in Siberia is until you have been through one. Even during the months of May and June there is sometimes frost at night.

Take plenty of note-books and pencils.

Do not attempt to develop photographs except at Tomsk, where you can go to the University.

No explorer should visit the Altai without obtaining information from the Tomsk University. If possible, he should also give them a lecture on the result of his tour, as they are all keenly interested in the Altai. 


\section{Appendix}

The climber should take exceptionally good steel crampons, especially sharpened for the very hard ice, and sharp, long steel nails in Alpine boots, also a particularly sharp ice-axe, somewhat larger and heavier than the largest Swiss Alpine axe, of the very best steel and with a very sharp head. The ordinary Alpine axe would have no effect upon the intensely hard ice.

The most serious difficulty in climbing Siberian mountains is to provide oneself with warm enough clothing without being over-taxed by their weight. Then it is not advisable to rely upon getting either bread or flour in the Southern Altai. We felt the loss of fresh bread. We had only a few very stale rusks, which did not last a week. If one is likely to be there in cold weather, a mask should be worn to protect the face from the intensely cold wind or the wind created by driving a sledge.

The outfit for climbing in Switzerland is too well known to need mentioning, and other kinds of climbing do not require any special outfit. 

I N D E X 



\section{INDEX}

\section{A}

\section{ABBI, 109}

Abraham, the Brothers, 60 d'Abruzzi, Duc, 257-8, 26 I Aconcagua, ascent of, 231-44, 255, 26 I

Adamson, $\mathrm{Mr}, 202$

Akkem valley, Ir8-r9, 165

Alle Blanche valley, 86

Almacen Peak, 238

Altai Mountains, climbs in the, $9 x-166$

Altaiskoë, 104-6, bear-hunting at, 106

Andes, the, 227, 233

Aorangi Mountain, 203

Arête, 168

Argentine, see South America

\section{B}

Balancing, powers of, 25 I57

Ball hut, 183, 198-200, 206

Barnaul, I or

Belukha, 91-3, 95-8, II 7, I2 $3-5,139-58$
Binen, Joseph, 50

Binns, Mr A. H., 70, 75-6, 86-7, I 7 I 40,83

Biysk, 91, 95, ror-3

Bivouac Peak, 207-8, 230

Bodega Peak, $23^{8}$

Bolland, Mr, 232

Bosses du Dromadaire, 25

Bossons, Glacier des, 19

Bride, Mount, $25^{8}$

Buenos Ayres, 23I

Bye, River, 163

\section{C}

Cattrey, P., 92, 96, ro1-2

Caucasus, the, 164

Central Gully, Great End, 169

Chamonix, 19, 21

Charmoz, Aiguille des, 70-82

Cherapanoff, 149-50, I6 I

Chorni-Anni, 108

Clark, Mr and Mrs Inglis, 86

Clarke, Mr (N.Z. guide), I 77, 200, 202-3 


\section{Index}

Climbing difficulties, I 7 I-3 ; health giving and fascination of, 244-49; general survey of, 250.62

Col des Grands Montets, 87

Col du Mont Tondu, 86

Couttet, Joseph, I9, 70

Cook, Mount, 183, 185-6, 20 I-30, 26r

Cumberland, climbing in, $167-70$

D

Dome Glacier, 208-9

Dome, the (Mount Elie de

Beaumont), I 9 I, I95-6

Dome du Gouter, 25

Donne, E., 177, 204

Dru, Aiguille du, 19

Drysdale, Arthur, 254

Dufour Spitze, 45-6

\section{E}

Elie de Beaumont, Mount, I9 $\mathrm{I}-6$

Everest, Mount, 165, 243, 257-9

\section{F}

FAIRLIE, $226-7$

Fitchett, Dr, $195-6$

Fitzgerald, $\mathrm{Mr}$, 202-3
Fyfe, T. C., 184-5, 189-90, 192-204, 208-26

G

Garth, Mountain, 54

Géant, Aiguille du, 85-6

Geneva, Lake of, 27

Gorner Grat and Glacier, 43-6

Graham P., I9I, 200, 203-4, 208-26

Grand Plateau, 24, 209

Grandes Jorasses, 77

Grands-Mulets, 20-2 2

Great Chimney, the, 168

Great End, 169

Great Gable, 168

Green, Rev. Mr, 202

Green's Saddle, 22 I

Grépon, Aiguille des, 74-5

Grépon-Charmoz, 2 I 9

\section{$\mathrm{H}$}

HaAst Peak, I86, 207

Halford, E. S., 19

Hardman, Mr, 23 I, 235-4I

Head, Captain, 203

Hebling, Dr, 232-4, 266

Helley, R. S., 254

Hermitage, the, 199-200, 205 , 226

Himalayas, the, $164,259-6 \mathrm{I}$

Hochstetten ice-fall, 207 


\section{Index}

Holmes, A. B., 32, 60-61, 6468

Hooker Glacier, 222, 25

Hornli ridge, 33

Hotels in Russia, 274

\section{I}

ILAM Rock, 60-68

Inexperienced climber, an, 45-50

J

JAMES, L. V., 254

K

$\mathrm{K}_{2}, 257-8$

Kaimanawa Mountains, 182

Kalmuck people, the, $160-2$

Katunda, II 2, I 7,163

Katun, River, $11_{3}, 163$

Katunskië-Belki Mountain, I 9-36, 165

Kauffman, Brothers, 202

Kennan, George, I 33-4

Ker Knotts, ascent of, 60 , 219

Koksa, I ro-r I I

Korgomskië Mountain Pass, 110

Krasnobaisk, 103
L

LARDEN, WALter, 232-4

Lendenfeldt Peak, 186, 198

Liebig Mountains, 184, 186-9

Low, Mr, 203

\section{M}

M'Donald, Mr, I99, 26

Malte Brun range, 184,186 , I9I, 195, 200, 204

Mannering, Mr, 202

Marefski, Captain, r 33

Matterhorn, ascent of the, 32, 42

Melia, 108

Mer-de-Glace, I 9

Mickledore Pass, 169

Midi, Aiguille du, I9, 85

Mont Blanc, ascent of, 18-3 I ; the Aiguilles of, 70-87

Monte Rosa, 33-4 ; ascent of, 42-52

Mountain formation, theory of, 165

Mountaineering, see climbing Mugnier, François, $70,76,78$,

82

Muller Glacier, $20 \mathrm{I}$

Mummery, A. F., 71, 82

Murchison, river and valley, 184, 186

Murett, Dr, 34-5 


\section{Index}

$\mathbf{N}$

Nantillon Glacier, 72-3, 83

Napes Needle, 168

Neale, J. J., 54-60

Newton, Rev. Mr, 203

New Zealand Alps, climbs in,

$177-230$

Ngaruruhoe, $178-83$

Nietzchie, Dr Lehmann, 231, 266

Nose Rock, 168

Novo-Nicolaëvsk, 164, 273

Nun's Veil, 184, 188-9

\section{O}

Obi Station, 91, 96; River, IOO, II 3

Orcones, Mount, 236, 238 ; geological formation of, 242-3

Oshlikoff, Mr, I I I

Ouemon, II 2

Ouskam, Io9

Outfits, 265-75

РАyot, F. K., I9

Penetenteries, the, ${ }^{2} 38$

Petit Plateau, 23-4

Pilatus, Mount, 16

Pillar Rock, the, I 68

Plan des Aiguilles, 72

Ponte del Inca, 234, 240-1

Priests' Cap, 188

Proud Falls, 185

Pukai, Lake, 2 I 5

Pulse variations, $255^{-6}$

$\mathbf{R}$

ReIChert, Dr, 232

Riga, 95

Rigi, the, 16

Robertson, Mr, 231, 235-40

Ross, Carnegie, 232

Ross, Malcolm, 184, 192-204, 208-26

Rothe, Herr, 23

Rotorua, I 78, 180

Ryan, Mr Danby, 178

\section{S}

Sapozhnikoff, Professor, 91-3, 95-6, I I3, I17, I50, 162, 274

Saptam Mountains, 96, 1 I316

Sealey, Mount, I84, I89-90

Sefton, Mount, 203, 227

Shimelovskaya Pass, ro7

Shroder, Professor, 266

Siberia, climbs in, 91, 26r

Silberhorn Peak, 186

Simond, Michel, 23

Sitchef, Mr, I०3 


\section{Index}

Ski-ing in the Altai Mountains,

114

Skipping exercise, 244, 253-4

South America, climbs in, $231-45$

Sparks, J., 254

Step-cutting, 2 I6-I 7

Sweeney, Mr, 178

Switzerland, climbing in, I588

\section{$\mathbf{T}$}

Taconnaz, Glacier de, 22

Taihape, I82

Tasman Mountains, I83-4, I 86, 2 I6

Taupo, Lake, I 78-9

Tavourack, I07-8

Teichlemann, Dr, 203

Thian-Shan, 165

Thompson, Peter, 54-8

Tolosa Peak, 238

Tomsk, Governor of, 96-8 ; mountains from, 165 ; assistance of governor of, 274

Tomsk, 91, 96-8, 274

Top Rocks (Mount Cook), 2 I I-I 2

Travelling in Russia, 98-100

Tupungano, 233
VISP, $3^{2}$

\section{W}

WAIOURU, I 78, 182

Wallaker, Rev. A., 6r

Walnut Tree Climb, 53-60

Walter, Mount, 192

Wastwater, 167

Watch Tower ascent, 60

Webster, Dr Garcia, 182

Wedgwood, Mr, 23 I, 237

Whymper, Edward, 38, I 31

Wick, ascent of Charmoz by,

82

Willer's Peak, 131, I33

\section{Y}

Yarlow, River, I 20

\section{Z}

ZERMATT, 32, 4 I

Zurbriggen, Mattias, 202-3, $212,228-30$

Zurrier (guide), 40 
EDINBURGH

COLSTONS LIMITED

PRINTERS 


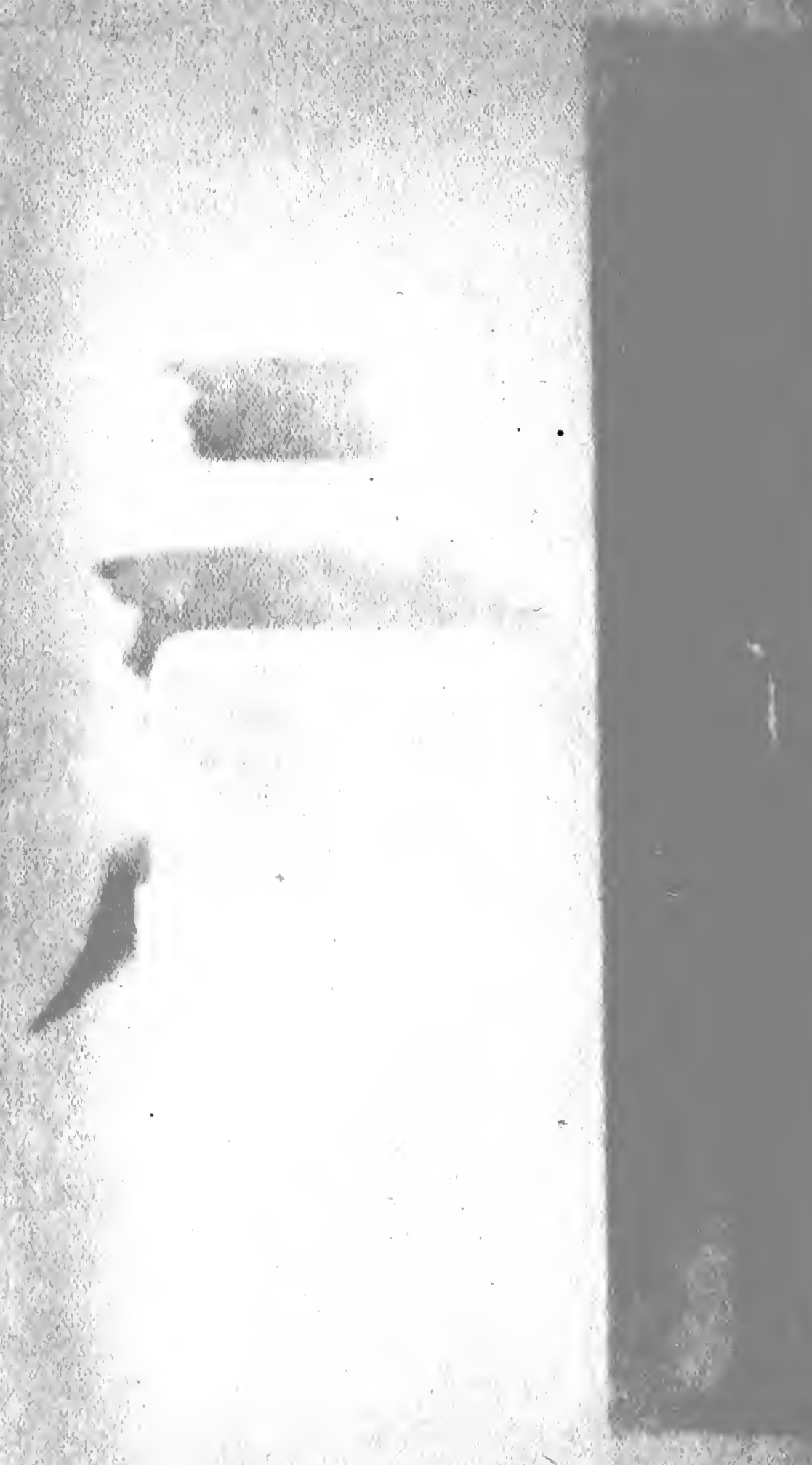




\section{PLEASE DO NOT REMOVE \\ CARDS OR SLIPS FROM THIS POCKET}

\section{UNIVERSITY OF TORONTO LIBRARY}

G

512

T8A 3
Turner, Samuel

My climbing adventuras in four continents 
